Running Head: ENFORCEMENT OF SCHOOL'S DISCIPLINE POLICIES

Teachers' and Students' Perceptions of the Effective Enforcement of School's Discipline Policies

Souheir M. N. Abu-Zahr

Lebanese American University 


\title{
Teachers' and Students' Perceptions of the Effective Enforcement of School's Discipline Policies
}

\author{
A Project Presented to the Faculty of \\ The Education Department \\ In Partial Fulfillment \\ Of the Requirements for the Degree of \\ Masters of Arts in Education \\ Emphasis: Education Management
}

By

Souheir M. N.Abu-Zahr

Under the direction of

Dr. Mona Nabhani

Lebanese American University

June, 2010 


\section{Lebanese American University}

We hereby approved the project of

Souheir M. N. Abu-Zahr

Teachers' and Students' Perceptions of the Effective Enforcement of School's Discipline

Date submitted: June, 2010

Education Department

Dr. Mona Nabhani, First Reader:

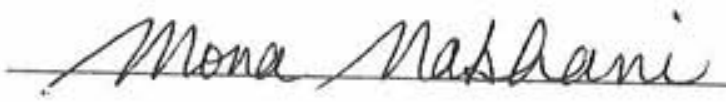

Dr. Rima Bahous, Second Reader:

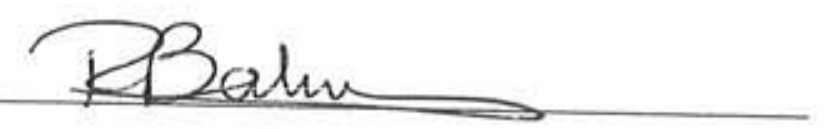

A copy of the project is available for research purposes at the University Library
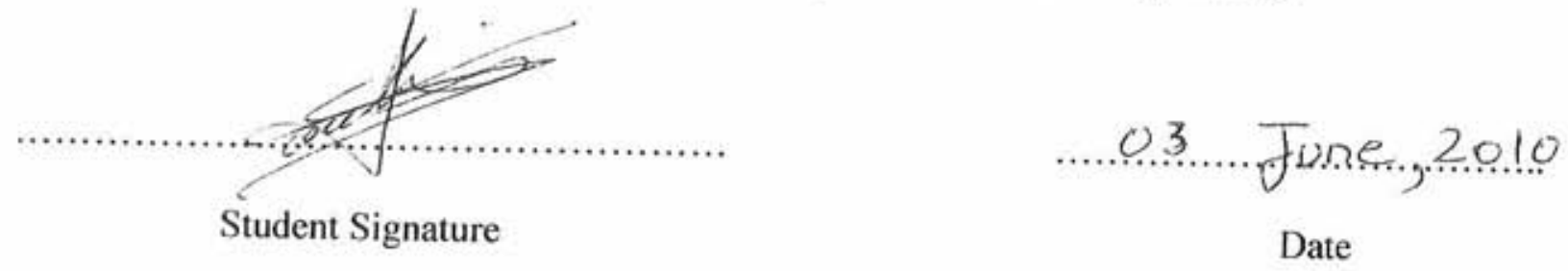


\section{Plagiarism Policy Compliance Statement}

I certify that I have read and understood LAU's Plagiarism Policy. I understand that failure to comply with this Policy can lead to academic and disciplinary actions against me.

This work is substantially my own, and to the extent that any part of this work is not my own I have indicated that by acknowledging its sources.

Name: Souheir M. N. Abu-Zahr

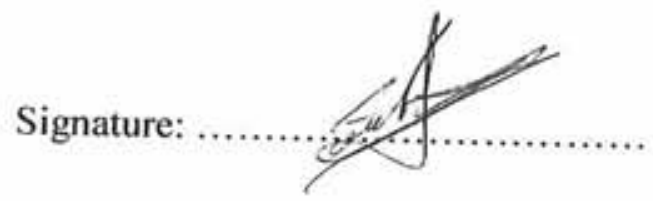

Date: June, 2010 
I grant to the LEBANESES AMERICAN UNIVERSITY the right to use this work, irrespective of any copyright for the University's own purpose without cost to the University or to its students and employees. I further agree that the university may reproduce and provide single copies of the work to the public for the cost of reproduction. 


\begin{abstract}
The study purpose is to evaluate the consistency between written and enforced discipline policies in a private school in Beirut, Lebanon, and to explore the middle school teachers' and students' perceptions of such enforcement. Based on the assumption that the early adolescents tend to have many discipline problems, the research questions were: How were written discipline policies enforced at school? And what were the perceptions of the Intermediate teachers and students of the effectiveness of such enforcement? As a non-participant observer, triangulation of data was achieved by using analysis of school's written codes, observations, students' and teachers' questionnaires and review of personnel's discipline records. A purposive sample of 131 participants were surveyed; 112 students ( 53 boys, 59 girls) and 19 teachers ( 8 males, 11 females). The case study with mixed methodologies lasted for six weeks at the beginning of the school year 2009-2010. During classroom observation, frequencies and percentages of the students' discipline violations was compared to the teachers' reactions, students' referrals and administrative reactions. Alignment between written codes and enforcement were found on codes of jewelry, smoking, absenteeism, homework, physical bullying and tardiness while cheating, hair style, uniform and verbal bullying had partial alignment. No alignment was found
\end{abstract} on codes of disruption, chewing gum, cell-phone, eating in class, forgetting materials, bad language, vandalism and emotional bullying. The male Intermediate students tended to violate rules more than females except for the policy against eating in class. The findings were that teachers slightly enforced discipline codes whereas administrators moderately enforced them. Many students got away with breaking rules due to shortage of reporting on their infractions in playground while in classes; teachers tend to report less frequently if they had management problems, their philosophy was not in harmony with that of the school and if the students had 
relatives of power positions in the school. Unfair enforcement resulted in altering the school's philosophy from authoritarian to erratic. Some students' perceived that strict discipline enforcement was applied by teachers and the school needed no modification in the discipline policies whereas others believed that teachers were lenient and some changes are needed in the written codes. As for teachers, the majority believed that inconsistent enforcement was applied and the school was in need of minor changes in codes. 
Dedication

I sincerely dedicate this work to my children, husband, and mother who waited long days and hours for the accomplishment of this project. I am greatly indebted to them for their emotional support especially in the moments of stress. They inspired and helped me to have confidence in my work. Thank you for everything. I love you all! 


\section{ACKNOWLEDGEMENTS}

It is a high privilege for me to express my deep sense of gratitude to all faculty members who helped me in the completion of the project, especially my advisor Dr. M. Nabhani and Dr. R. Bahous. My special thanks go for both of them for always helping me at hours of need, and for their helpful comments and guidance throughout.

I wish to express special appreciation for the cooperation of the school principals, administrators, supervisors, and teachers who participated in this study. Not only did they assist me in each step of the data collection, but they also provided valuable feedback which was taken into consideration. Throughout the study both supervisors and administrators were extremely cooperative and open in providing me access to requested data and to persons whom 1 wished to interview and observe. I am appreciative and remain in debt to these persons and to our participating teachers and students, all of whom remain nameless in this report. 


\section{TABLE OF CONTENTS}

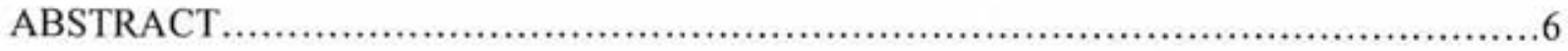

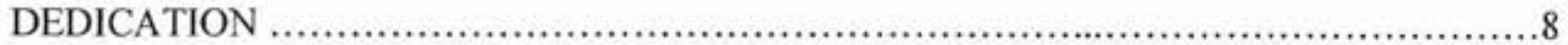

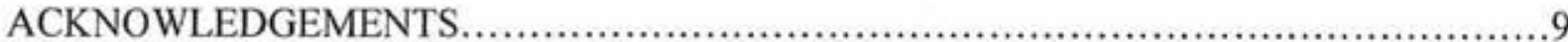

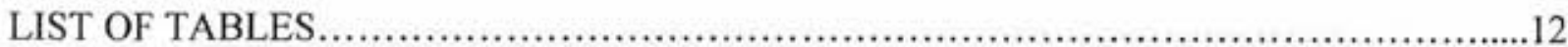

Chapter

INTRODUCTION

Background and Research Questions.....................................................................14

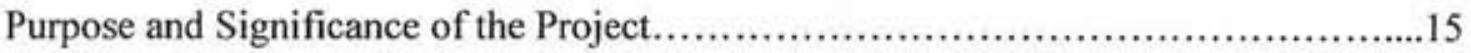

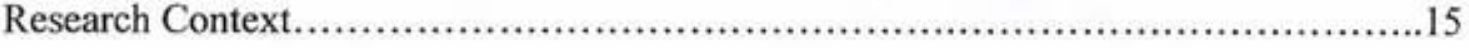

REVIEW OF LITERATURE

Discipline Policies Competing Theories............................................ 18

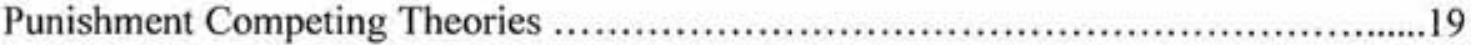

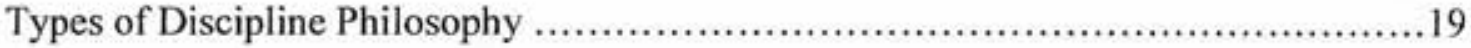

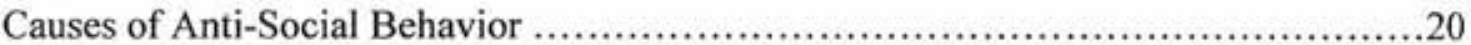

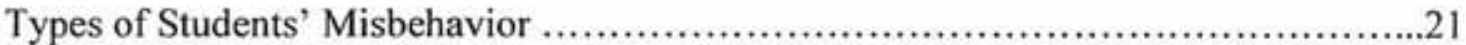

Discipline Problems and School's Characteristics .......................................22

Remedial of Current Schools' Discipline Policies.........................................24

METHODOLOGY

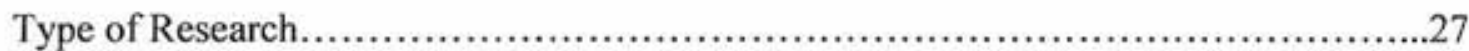

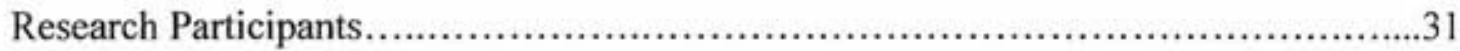

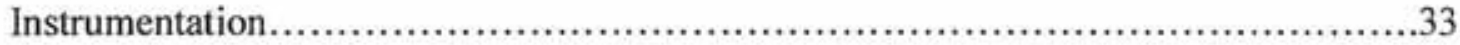

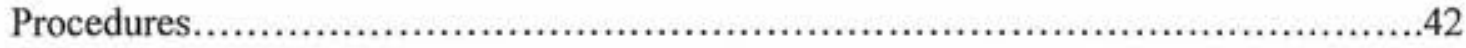

RESULTS

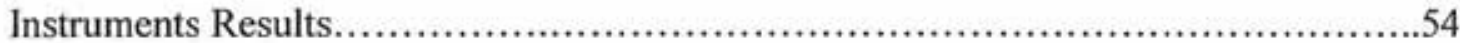

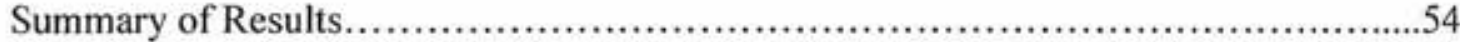

FINDINGS

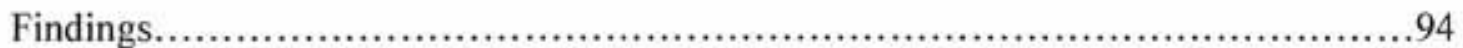




\section{CONCLUSION AND RECOMMENDATIONS}

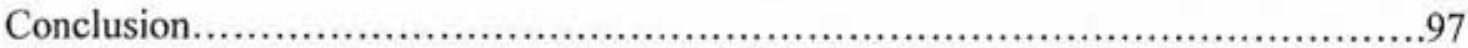

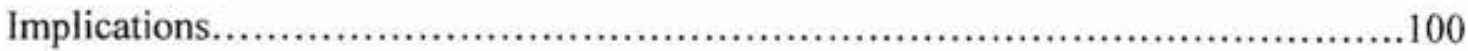

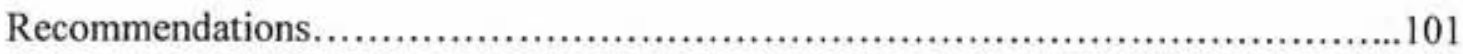

Limitations of the Project............................................................. 104

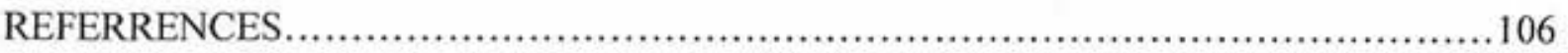

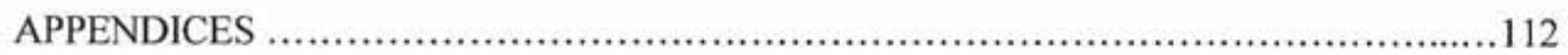




\section{LIST OF TABLES}

TABLE 1 Bullying Cases in Playground

TABLE 2 Vandalism Cases in Playground

TABLE 3 Playground Data

TABLE 4 Evaluations of Corridors and Stairs Rules Enforcement

TABLE 5 Classroom Disruption Violations of Seventh Graders

TABLE 6 Classroom Disruption Violations of Eighth Graders

TABLE 7 Classroom Disruption Violations of Ninth Graders

TABLE 8 Intermediate Disruption Violations in Classroom, Playground, Corridors, and Stairs

TABLE 9 Evaluation of Disruption Rule Enforcement

TABLE 10 Homework Violations at Intermediate Levels

TABLE 11 Teachers' Reactions on Homework Violations

TABLE 12 Evaluation of Homework Enforcement at Seventh Grade

TABLE 13 Evaluation of Homework Enforcement at Eighth Grade

TABLE 14 Evaluation of Homework Enforcement at Ninth Grade

TABLE 15 Evaluation of Homework Enforcement at Intermediate Levels

TABLE 16 Intermediate Violations of Forgetting Books

TABLE 17 Teachers' Reactions on Forgetting Class Books

TABLE 18 Intermediate Referrals on Forgetting Books

TABLE 19 Evaluation of Bringing Classroom Materials at Seventh Grade

TABLE 20 Evaluation of Bringing Classroom Materials at Eighth Grade

TABLE 21 Evaluation of Bringing Classroom Materials at Ninth Grade

TABLE 22 Evaluation of Uniform Code Enforcement 
TABLE 23 Evaluation of Hair Code Enforcement

TABLE 24 Evaluation of Jewelry Code Enforcement

TABLE 25 Intermediate Bullying Violations

TABLE 26 Classrooms and Playground Emotional Bullying Violations

TABLE 27 Evaluation of Emotional Bullying Code Enforcement

TABLE 28 Classrooms and Playground Verbal Bullying Violations

TABLE 29 Evaluation of Verbal Bullying Code Enforcement

TABLE 30 Classrooms and Playground Physical Bullying Violations

TABLE 31 Evaluation of Physical Bullying Code Enforcement

TABLE 32 Evaluation of Not Using Bad Language Code Enforcement

TABLE 33 Intermediate Vandalism Violations

TABLE 34 Evaluation of Vandalism Code Enforcement

TABLE 35 Evaluation of Not Eating in Classrooms/Laboratory Code Enforcement

TABLE 36 Evaluation of Chewing Gum Code Enforcement

TABLE 37 Evaluation of Cheating Code Enforcement

TABLE 38 Summaries of Intermediate Discipline Violations

TABLE 39 Summaries of Teachers' and Supervisors' Reactions to Discipline Violations

TABLE 40 Summaries of Discipline Policies Enforcement at Intermediate Levels

TABLE Q1 Alignment between Written Codes and Discipline Enforcement 
Introduction

The enforcement of discipline policies is essential for the school to direct students' behavior and creates an environment conducive to learning (Cameron, 2006). According to Gaustad (1992), "school discipline policies had two major roles: to ensure the safety of schools" employees and students" (p. 1). However, written discipline policies do not mean that they are being reinforced properly and that they have an effect on the students' behavior. Discipline policies should be implemented at school by the administrators, teachers and staff in order to have better management of the students' behaviors. Since classrooms are the responsibilities of teachers and the students are most of their time in the classrooms' settings, the major responsibilities lay on the shoulders of the classroom teachers to enforce the school's rules consistently without instances of favoritism or neglect (Gaustad, 1992).

Recently, many schools had serious problems with students' discipline; in fact, the classrooms are increasingly crowded with young people who are violating the school's rules. A survey conducted by the Public Agenda (2004) revealed that one in three teachers considered seriously quitting the teaching profession because of the students' unbearable behavior and discipline.

Most of the reviewed literature was conducted in West, I only found very few studies that were conducted in Lebanon, which motivated me to conduct the current research with the following research questions: "How are written discipline policies enforced in a private Lebanese co-educational school located in Suburb of Beirut? And what are the perceptions of the middle school teachers and students about the effectiveness of such enforcement? 


\section{Purpose and Significance}

The purpose of the current research is to investigate the alignment between the written school discipline policies with practice and to elicit the perceptions of the students and the teachers about the effectiveness of such enforcement. As for the significance, the current study will help school administrators gain a better understanding of the teachers' and students' perceptions of the school's discipline policies. From this, they can gain insight into features of school policies that could be improved to direct the students' behaviors and foster better school environment. In addition, the rationale for conducting this study only at the middle school levels is that adolescent students are about to enter a turbulent stage in their lives which could affect their behaviors. Lipsitz (1982), Williams (1983), and Evertson, Sanford, and Emmer (1981) pointed out that young adolescent students tended to have the most disciplinary problems.

\section{Research Context}

The school under study is a K-12 co-educational school that is run by "The Schools Committee" that was appointed by the Church Board of a certain Church in Beirut. The school is part of a small rural area, and it is surrounded with houses near industrial development. Its building had an "L"'shape with three floors that surrounded one small campus which was also used as a Basket-ball court. The school building is well maintained and houses k-12 levels; the preschool has a separate building across the street near the school. The ground floor includes the supervisor's office, the classes of the Seventh, Eighth grades, the humanity section of the $12^{\text {th }}$ grade, one small cafeteria, computer center, and bathrooms for both sexes. The first floor includes the classes of the Ninth grade and all the classes of secondary levels, the administrative offices, and the male teachers' room. The second floor is for the Elementary levels and the 
female teachers' room; and the last floor is a playground for the Elementary level. The BasketBall court is used as a campus for the Intermediate and Secondary levels.

The supervisor's office is located near the stairway facing the court with a glass facade which allows the supervisor to observe and monitor the students during their presence on campus even when he is behind his desk; yet he could easily be in the hallways to supervise the students when the bell rings.

Based on the school's documents, the school under study follows an academic, educational, humanitarian, and national mission that aims at developing educated, humanitarian and conscientious citizens open to all thoughts, principles, and convictions who also believe that all human beings are equal despite their colors, religions, social classes, or nationalities.

The school follows The Lebanese Official Curriculum and prepares its students to pass the Lebanese Official Exams and join the most prestigious Universities in Lebanon and abroad. The school uses English as its first foreign language, and French its second one. In addition to the main academic subjects, there is emphasis on music, singing, drawing, handicraft, theater, and computer skills until the Secondary levels. The school's graduate students for the current year were 43 students who after graduation become members of the Alumni Association which was founded few years ago.

The school serves the purpose of my study because "The Schools Committee" accepted to provide me access to their school to collect the needed data for my research. They even allowed me to start my observation of Intermediate classes, playground, and hallways from the beginning 
of the school year even before training the students to follow the school's disciplinary policies. This helped me indirectly compare the behavior of the sample before and after training.

In addition, the school administrator provided me from the second meeting with all the necessary documents concerning their discipline policies, as well as personnel records which reflected the procedures followed for enforcing school's discipline policies through sanctions and punishments, and the ways of handling the students' cases with the parents.

As for the organization of this document, it includes six chapters. The previous sections are the first chapter that presents the introduction of the research which includes the research questions, the purpose and significance of the project, and the research context. The following chapter presents the review of the literature whereas the third chapter presents the research methodology. Data results are presented in the fourth chapter while the findings are presented in the fifth chapter. The last chapter presented the conclusion, implications, recommendations and limitations of the research. 


\section{Literature Review}

Previous research was reviewed concerning the following topics: the discipline policies' competing theories; the punishment competing theories; the types of discipline philosophy; the causes of anti-social behavior; the types of students' misbehavior; the discipline problems and school's characteristics; and the remedial of current schools' discipline policies. This will be used later on to compare my findings against those stated in the reviewed literature.

\section{Discipline Policies' Competing Theories}

Prior research presented many competing theories in the field of school discipline policies such as the open system model (Katz \& Kahn, 1978), and the internal processes control model (Likert, 1967). Each model is distinguished by its emphasis on specific organizational process and standards, which in turn reflects the desired output and the way schools implement its policies and procedures to regulate and influence students' staff, and parents' behaviors.

The open system model emphasizes the employees' empowerment, innovation and flexibility. It engages freely with the external environment. It also views students' discipline as problem solving process which allows teachers to experiment with students' behavior and practices in order to achieve their compliance with schools' rules whereas the internal process control model emphasizes orderly work environments through the control of internal activities and processes of students and staff associated with tough discipline rules (Griffith, 2003).

These two competing theories, the open system and the internal process control model, reflect the philosophy of the schools which influence the discipline policies and the ways of enforcement. Of course, there are schools that have an eclectic model which is the combination of these two models. Therefore, one of my prior concerns in my current research will be to 
identify the philosophy of the school during the content analysis of the school's documents concerning discipline policies.

\section{Punishment Competing Theories}

On the other hand, the school's responses to students' misbehavior have the following competing theories: the corporal punishment approach, the suspension and exclusion approach, in-school suspension approach, the zero tolerance approach, medicalization of discipline approach, conflict resolution approach, the peaceful approach, the moral approach, the constructivist approach, and the holistic approach (Adams, 2000). Therefore, in the current research, the enforcement of discipline policies and the ways of responding to students' misbehavior reflect the teachers' philosophy despite the school philosophy that is reflected in the written codes.

\section{Types of Discipline Philosophy}

Metz (1978) developed a typology for identifying the four discipline philosophies of schools which are the authoritarian, the incorporative, the developmental, and the therapeutic. In the authoritarian philosophy, the educational goals and rules are not shared. The administrators and the teachers responded to students' misconduct through punitive attitudes that could reach to corporal punishment. In the incorporative philosophy, the school's goals and rules are shared with the students; the administrators and the teachers integrate the school's rules into the students' life until they become part of the learners. In the developmental philosophy, the educational goals and rules are shared with the students; the administrators and teachers participate with the students in directing actions. They even tried to explain the possible causes 
of pro-social and anti-social adolescent behavior by identifying: a) the opportunities, the skills learned, and the recognition that the student received in his/her social environment; b) the student's consistent and successful involvement that lead to attachments and commitments with the social unit(s); and c) the student's adopted beliefs and behavioral standards that created informal behavioral control of the student. Finally, in the therapeutic philosophy, the schools tried to help reduce the problems of anti-social adolescent behavior by providing prevention, intervention, and therapeutic programs (Ayers \& Shavel, 1997). Therefore, in my current research, the ways of responding to students' misconduct by the school administrator(s) and personnel will reflect the school's philosophy. This will help evaluate the enforcement of the school's policies based on the school's philosophy. Thus, Metz is considered as one of the pioneers that will help me to identify the type of philosophy by using his typology for further analysis.

\section{Causes of Anti-Social Behavior}

Many researchers linked the students' anti-social behavior to the external influences, to the violence surrounding the society (Barrett, 1993; Hawkins, 1996; Mesinger, 1984; Walker, 1993) to the socio-economic status of the students and parents, to the family income, to the background of the family, and to the peer pressure (Brown, 1993; Mason, 1996; Silbereisen, 1990). Other research tried to link the students' misbehavior to internal factors such as school climate or "ethos" which is the characteristics and distinguishing attitudes, habits, beliefs of schools' individuals and groups (Rutter, Maughan, Mortimore, \& Ouston, 1979), and to the school policies and the enforcement of these policies by the administrators, the teachers, and the school personnel (DeJung, \& Duckworth, 1985). Other researchers linked it to the combination of 
external and internal environment, such as the influence of schools, peers, and family on students' behavior (Rutter, 1983; Seydlitz \& Jenkins, 1998; Sheldon \& Epstein, 2002).

\section{Types of Students' Misbehavior}

Moles (1989) found that students' misbehavior involved criminal behavior and non-criminal behavior. The most common problems of students' misconduct are non-criminal behavior that should be treated flexibly depending on the circumstances whereas students' criminal behavior should be treated with nonnegotiable consequences (Gaustad, 1992).

Gottfredson (1989) concluded that noncriminal students' behavior such as the disruptive behavior did not threaten personal safety, but affected negatively the learning environment. They also concluded that the total students who were punished through the Out-School-Suspension (OSS), and the In-School-Suspension (ISS) in six middle schools in Charleston, South Carolina, lost 7,932 teaching days in a single academic year which is equivalent to 44 years.

However, Goodman (2006) found that students' infractions have three main categories: First, intentional moral violation or criminal behavior such as vandalism, violence, theft, deception, assault, cheating, plagiarism, and carrying drugs, tobacco, and weapons on school premises.

Derivatively or non-intentional moral violations are the second category such as eating outside the cafeteria. Non-moral or conventional violations are the third category which are related to classroom management such as absenteeism, tardiness, and dress violation (Nucci, 1989, 2001; Turiel, 2002). 


\section{Discipline Problems and School's Characteristics}

Gottfredson (1989) found after conducting his research on 600 Secondary schools' participants that schools with discipline problems had the following characteristics: rules were unclear and inconsistently enforced; learners perceived the rules as unfair and didn't believe in them; the teachers and administrators were in conflict about the proper way of responding to students' misbehavior such as the teachers responded in punitive attitude to students' misconduct due to administrative inactive behavior; and the schools' area was large and lacked proper teaching resources (Gaustad, 1992). After reviewing dozens of studies on students' behavior, Duke (1989) reached the conclusion that orderly schools should be small in size, have fewer formal rules, and have a flexible approach to students' misconduct, communicate clearly its rules with the students, and create a climate of concern for the students. In addition, he found that the school's principal played an important role in enforcing the schools' discipline policies by being role models of school discipline, and by having an effective administration (Gaustad, 1992). Gottfredson (1989) agreed with Duke (1989) that large schools should be divided into mini-schools according to age range in order to have better control of school discipline.

Meyers, Kenneth, and Pawlas (1989) recommended the schools' administrators who aim for an atmosphere conducive to learning should communicate its rules to staff, teachers, students, and parents through several means such as newsletters, students' assemblies, and handbooks. They added that it is preferable to remind the school practitioners of the school rules after the winter and summer vacations. In addition, students' respect to school's discipline system could be gained through the communication, the consistent enforcement of fair rules, and the provision of few individuals for the enforcement in order to have greater consistency (Gaustad, 1992; 
Goodman, 2006). Therefore, in my current research, the more the school under study uses the different ways of communicating its rules and policies, the more the enforcement will be on the school premises.

Duckworth (1984) found that the administrators played important roles as communicators of schools' discipline policies by having good relationship with teachers, communicating and sharing common values with the staff to create consensus on schools' rules and the way of enforcement. The schools that implemented a piloting program experienced success and good improvement in students' discipline (Gaustad, 1992).

Therefore, it is very important to check the ways of communicating the school's discipline policies by the teachers, staff, and administrators. This could be achieved through successive observation on the school premises.

In the Discipline Handbook for Effective School Administrators, Black and Downs (1992) urged the administrators to communicate the schools' disciplinary referrals to the students as a way to teach them important social skills which could provide success in future employment. Edmond (1979) and Brookover (1979) emphasized that schools could be effective in conducting classroom lessons if they had orderly and nonopressive environment. If the students were in conflict with their school environment such as the administrators, teachers, and classmates, this affected negatively the teaching-learning process and the attendance rate. In addition, the late and absent students would disrupt the teaching, cause decrease in learning time, and prevented administrators from providing more time to improve the learning process (DeJung \& Duckworth, 1985). 
After schools' crises of violence and drug dealing in the West, the administrators tended to change the school's policies because they were held responsible for their ineffectiveness. Duke and Meckel (1980) found that the school administrators had the illusion of improvement after adjusting the school's policies because they believed that the spent time, energy, and concern were sufficient for improvement; they didn't assess the new policies' effectiveness and didn't collect enough data to verify their beliefs. This is one of many reasons that my study is important, because it will provide the school administrators with the substantial evidences about the effectiveness of their school's discipline policy and it will clarify and reflect the opinion of their students and their teachers in the effectiveness of such enforcement. In addition, Duke and Meckel stressed the importance of discussing the school's crises between the administrators, teachers, and students to find the proper solutions. The majority of research related to my study is conducted on middle grade and junior high schools because the researchers found that the most discipline problems started with early adolescence (Lipsitz, 1982; William, 1983; Evertson, et al, 1981).

Remedial of Current Schools' Discipline Policies

Goodman (2006) believed that the current schools' disciplinary policies are ineffective tools for delivering moral messages because they are poorly justified and schools tended to apply the same punishment on moral and conventional violations such as using detention and suspension to moral and non-moral violations without discriminating between the violations. Therefore, schools' disciplinary policies are perceived as unfair, irrational, and trivial.

As a remedy, Goodman (2006) believed that schools should apply sanctions to the derivatively moral and conventional violation whereas punishment should be applied only on 
intentional moral violations. He also believed that schools should apply the problem solving approaches as an attempt to understand students' violation cause, motive, and circumstances in order to stop the future harm. The problem solving approaches could be achieved through two aspects by reforming punishment through "discussion, assistance, suggestion, natural consequences, positive and negative reinforcement, anger management, peer mediation, social skills training, guidance counselor, school nurse, behavioral contracts, parent conferences, reprimands, withdrawal of privileges, work details, student-assistance resource program, and outside mental health referrals" (Goodman, 2006, p. 218). Another aspect of problem solving approach is to expand teachers' authority to determine the ways of interventions.

Cameron (2006) also believed that effective school discipline are reflected in professional actions such as consulting and training teachers and administrators on the benefits of nonpunitive methods; educating them on the potential harm of punitive actions; and developing school's behavioral rules with the collaboration of students, teachers, and administrators. Additional professional actions are clear articulation of fair and consistent enforcement of behavioral rules; changing school culture through campaign against bullying; consistent use of positive reinforcement approaches; increasing parental involvement; and providing conflict resolution services (Cameron, 2006).

Other intervention device was the "time out device" perceived by some researchers (Kohn, 1996; Preuesse, 2004) as punishment because it isolates the student who has misbehaved and deprived him/her from peer interaction whereas Charney (1991) saw it as rehabilitative and protective device because it enhances the student's incentive and dignity of self-control. 
Watson and Ecken (2003) revealed that schools' intervention should offer support and guidance instead of punishment such as addressing the causes and context of the students' conflict. Noddings (2002) called for investigating the possible causes of students' tardiness and linked it to home conditions; Noddings (2002) perceived students' discipline violations as problems to remediate and not to punish for whereas Bear (1998) believed that schools' morals are decreased when classroom management are reduced and schools avoided punishment.

Other studies (Goodman \& Lesnick, 2001, 2004) found that the students perceive school rules as legitimate and abide voluntary to them when there is an alignment between schools' moral objectives and curriculum goals. Therefore, schools should be encouraged to clarify their moral objectives to its practitioners; and the teachers should articulate schools' moral objectives to students when needed. Goodman (2006) revealed that one aspect of student - adult - school moral alignment is to increase the students' engagement in aspects of discipline such as providing “class meetings, students' government, students disciplinary bodies" (p. 226).

The previous sections presented the literature review concerning the discipline policies' competing theories, the punishment competing theories, the types of discipline philosophy, causes of anti-social behavior, the types of students' misbehavior, the discipline problems and school's characteristics, and the remedial of current schools' discipline policies. The following section presents the methods used in the current research. 


\section{Methods}

This chapter presents the methods used in the current research which includes the type of research used, the participants, and the research instruments: the teachers' and students' questionnaires, observation sessions, and the reviewing of school's documents concerning the discipline policies, the students' referrals records, and the personnel discipline records. Later, the chapter presents the procedures used, triangulation of concepts, and discussion of reliability, validity, internal validity, and generalization. The last part presents the researcher's role and the research ethics.

\section{Type of research}

The type of research is a case study in which the researcher uses documenting and portraying the everyday experiences of predetermined group(s) for a period of time to obtain a complete picture of a specific subject or phenomena without manipulating any of the variables under study or participating in any of the groups' activities (Travers, 2001).

Based on the above definition, the case study as a design fits my topic and my research questions because as a researcher, I have previously determined the participants of my research which are the students and teachers of all the Intermediate levels. In addition, my goal as a researcher is to obtain a full picture of the effective enforcement of school's discipline policies which is a long process that needs to be implemented over time by many school's individuals (Burns, 2000). 


\section{Advantages of the current research.}

Choosing the case study for the current research provided many advantages such as comprehensive study with detailed and thick descriptions of the school's context and participants which involved describing what the researcher saw and heard during data collection (Cohen, Manion, \& Morrison, 2000). In addition, the study of real-world situation was used without any manipulation of variables by the researcher. Furthermore, accurate data were obtained during the time that was spent on school's premises while observation of Intermediate classrooms, hallways, and playground (Fraenkel \& Wallen, 2008). Moreover, inductive reasoning was used through the immersion in the details of data to discover important path such as the implementation of school discipline policies by the teachers and school's personnel (Bryman, 2001). Another advantage was to get deeper and richer understanding of the implementation of school's discipline policies due to the continuous observation of actual behavior of schools' individuals in their natural settings. The last advantage was the high probability of receiving $100 \%$ responses in the survey due to conducting the survey for the entire selected group at the same time in one school with the help of its supervisors. This provided the delivering of both questionnaires from authority position (Travers, 2001).

\section{Research variables.}

In the current study, the school discipline policies that were evaluated included the students' behavior inside and outside the classrooms, the students' dress code concerning hair, jewelry, clothes, and shoes; the students' truancy, punctuality, homework, and disrupting others; the students' safety from emotional, verbal and physical bullying in the hallways, and playgrounds; and the students' ethics concerning cheating, vandalizing, smoking, using bad language, cell- 
phone, and chewing gum, and eating during learning time in classroom, library, or laboratory. In addition, each discipline policy specified the types of punishment and sanctions that the student got in case of breaking any of the previously mentioned rules. Yet, the violation of forgetting classroom materials was another extraneous variable that was added to these research variables, since it could influence the classroom disruption. All the above discipline policies were the dependent variables used to examine the effective enforcement of these policies. There was no independent variable in the current research.

Therefore, continuous and extensive daily observation of teacher-student and student-student interactions were needed in many school setting such as in the Intermediate classrooms, hallways, and playground in order to identify the school's reactions on each student's violation of any of the previously determined discipline policies and to find out whether each policy enforcement corresponds to school's written codes. As a result, the focus in the research was to study each discipline case which made the case study a suitable design for my research (Tashakori, 1998).

Operational definition of effective enforcement.

In the current case study, the operational definition of effective enforcement based on the literature review included the following:

- The school's disciplinary policies were stated clearly in written forms and they were understandable to all the school members (Gaustad, 1992; Duke, 1989; Meyers, Kenneth \& Pawlas, 1989). 
- Each student got a disciplinary booklet at the beginning of the school year which listed the school's rules and the consequences of violating such rules. (Meyers, et al. 1989)

- All the parents received the disciplinary booklet at the enrollment of their children (Meyers, et al. 1989).

- All the school's teachers and staff received an up-to-date disciplinary booklet at the beginning of each school year (DeJung, 1984).

- The teachers and staff were involved in the development of the school's rules (Cameron, 2006).

- All the students were trained on the school's rules and procedures during the first two weeks at the beginning of the school year (Black \& Down, 1992).

- The duties of controlling the students' behavior were divided between the school's teachers and staff (DeJung \& Duckworth, 1984).

- The teachers were not lenient in enforcing the school's disciplinary policies (Gaustad, 1992).

- The enforcement of the school's discipline rules by the teachers had three major aspects: the consistency and the fairness of implementation of discipline rules, and the students learn self discipline as a step to meet the expectations of the school's personnel (DeJung, 1984).

- The student was immediately subject to consequences in case of violating the school's disciplinary rules (Adams, 2000).

- The teachers enforced the school's discipline rules without favoritism or neglect (Gaustad, 1992).

- The teachers reminded the students of the school's disciplinary rules from time to time depending on the circumstances (Meyers, et al. 1989). 
- The school communicated its policies and rules through newsletters, students' assemblies, and/or handbooks (Meyers, et al. 1989).

\section{Participants}

Based on prior educational research, those who studied the attitudes and behaviors of schools' individuals used the case study approach and chose purposive samples (DeJung \& Duckworth, 1985; Gottfredson, Gottfredson, \& Hybl, 1993; LaPoint, Alleyne, Mitchell, \& Lee, 2003). Usually purposive samples in the case studies are previously determined for having certain characteristics in order to study them extensively on daily basis through the use of various instruments for data collection such as observation, survey, interviews, and reviewing documents in order to formulate interpretations that are applicable in the future on similar cases (Fraenkel \& Wallen, 2008).

The sampling method used in the current research served me more than others; the study was conducted in one school which makes it essential to choose all the young adolescent students who may have the most discipline problems (Lipsitz, cited in DeJung \& Duckworth, 1985). Also, their teachers could be valuable sources of information for the study. Therefore, the students and their teachers were considered a typical purposive sample.

In the current research, the school was chosen as a convenience sample due to its nearby location to the researcher's house. The participants of the case study are 131 participants, 112 students and 19 teachers. All the Intermediate English students were surveyed, 53 were boys, and 59 were girls. Most of the participants were previous students while the new comers represented $5 \%$ only of the total number of their sample. The students' age ranged from 12 to 15 years; and 
most of them came from a middle socioeconomic status. The size of their classes ranged from 13 to 22 students per class.

The observed sample was the 112 students in two sections A, and B. The Seventh graders were 42 students, 21 students in each section, 23 males and 19 females. Also, the Eighth graders were 44 students, 22 students in every section, 17 males and 27 females while the Ninth graders were 26 students, 13 students in each section, 13 males and 13 females.

Due to the limited time that was provided for conducting the research, the school's administration had provided me between three to four weeks of classroom observation which pushed me to conduct three classroom observation sessions on daily basis for the three Intermediate levels. The duration of each observation was a whole period in any academic or leisure materials. The selection of the observed sections was done upon the approval of the academic supervisor and the teachers.

Out of the 19 Intermediate teachers, 15 were full-time teachers, and four were part-time teachers who were surveyed. Eight were males and 11 females, and the majority was veterans between 25 and 50 years of age. One of the male teachers was the priest of the school who provided the social studies material for the Intermediate and Secondary classes.

Having the majority of the teachers as full-timers provided perceptions of educators who spent most of their time on the school's premises. This could reflect their style of implementing the school's discipline policies more than the part-time teachers. 


\section{Materials: Instruments}

The instruments that were used in the current research were the students' and teachers' questionnaires; the observation checklists of hallways, playground, and the Intermediate classrooms; and the review of school's documents concerning the school's discipline policies, the students' discipline referrals, and the consequent penalties that are handled by the school's personnel.

The students' and teachers' questionnaires were part of the study that was done by DeJung and Duckworth (1985) for the Center of Educational Policy and Management in the College of Education at the University of Oregon, Eugyne. The survey questionnaires were used in the examination of the students' discipline policy in three middle district schools in the Pacific Northwest. The study of each district school was done as a case study in the students' discipline policy.

The purpose of both questionnaires was to collect information on teachers' and students' perceptions of each school's discipline policy and its effectiveness. This can help administrators gain insight into aspects of school policy that could be improved (DeJung \& Duckworth, 1985).

The current case study included quantitative and qualitative methodologies which made it a mixed method design. The quantitative method was used in the students' and teachers' questionnaires, in the students' referral records, and in the observational checklist while the qualitative method was used in my field notes during the observations sessions and in parts of the teachers' survey. 


\section{Teachers' Questionnaire}

First part of teachers' questionnaire.

The first part in the teachers' questionnaire (Appendix A) was adopted from the study that was done by DeJung and Duckworth (1985) who conducted the survey only on the full-time faculty members. The questionnaires were delivered by a member of the research team in the three schools. Each survey envelope included the questionnaire, a letter of explanation, a request for follow up interview and a stamped envelope for direct return mailing to the research office. The survey responses were anonymous in order to help the participants provide their true opinions on the school's discipline codes and its effectiveness in affecting students' behavior.

DeJung and Duckworth (1985) controlled validity and reliability through many steps; the teachers' questionnaire was reviewed by the schools' principals before it was distributed to the teachers to provide valuable feedback. A research assistant for the project was asked to supervise the data collection to compare the differences between the three schools, and to review the accuracy of the research report. Three external audits were used as editors to polish the final report of the study.

The Intermediate teachers' questionnaire of DeJung and Duckworth (1985) was divided into two parts; the first part includes sixteen multiple choice questions whereas the second part included a checklist table with ten teachers' comments on six discipline rules. The questions in general measured the effective enforcement of the school's discipline policies through three major aspects which are the consistency, fairness, and the personnel's expectations of the students' self discipline. The consistency as an aspect of enforcement could be weakened when 
the school's teachers are lenient or strict in the implementation of the discipline rules or when the application of the written codes differs according to the students' cases (DeJung \& Duckworth, 1985). This was measured by asking the teachers whether they were strict or lenient in the enforcement of the major discipline rules or whether it was the total staff business to enforce them.

Another aspect of enforcement is the fair application of discipline rules (DeJung \& Duckworth, 1985) that was measured by asking the teachers whether some students get away with breaking specific discipline rules more than others. Also asking the teachers whether the students are learning to make their own decisions about obeying discipline rules reflected the third aspect of enforcement which is the personnel's expectations that students learn self discipline. The rest of the questions ask teachers about the problems that may occur in enforcing the school's discipline policies and their suggestions to modify such enforcement.

DeJung and Duckworth in general asked the teachers whether the staff supported the school policy, how well their discipline codes were working, whether discipline problems were increasing or decreasing, and how much of the teachers' time was provided for managing student discipline.

All the above questions of DeJung and Duckworth (1985) were adopted in the current research because they reflected the ways the school reacted to students' referrals and the various ways in which discipline policies implementation corresponded to written codes. Most of the questions were not for a specific culture, so they could fit well my research questions, variables, and operational definition. Since the questions are multiple choice questions, the answers will be too general to measure teachers' dissatisfaction or satisfaction with the school policy. Therefore, 
more information and clarifications on the teachers' responses were needed. I added eleven questions, nine of which are open-ended questions and two are multiple choice questions. Five of these questions were designed based on my literature review and my research questions: the two multiple choice questions and one open-ended question asked about the safety procedures that the school takes to protect its members from bullying. Another open-ended question asked about the students' training on school's rules and its duration, and the last invented open-ended question asked about the school's rule that the teacher is lenient in enforcing.

In the current research, additional six open-ended questions were adopted from the survey that was conducted by the Association of Secondary Teachers, Ireland (ASTI, 2004). One of these questions asked the teachers if they had been provided with a booklet of the school discipline policy. Another question asked about the teachers' involvement in developing school discipline policy. Another asked if the teachers were satisfied with the manner of implementing these policies, and the reasons why they were or were not. Two more questions asked about the policy aspect they considered the least and most effectively implemented. The last question asked the teachers about the type of students' disruptive behavior that caused the most stress for them.

The purpose of the ASTI questionnaire was to provide a model for staff to review the implementation of school discipline policy and to check the participation of the school members in the examination of their policy with a view to make it more effective on a regular basis (ASTI, 2004). The questionnaire is considered as a guide and part of the School Development and Planning (SDPI) in Ireland. Each school principal should provide copies of this guide to the staff to review and develop policies. 
Second part of teachers' questionnaire.

In the current research, the second part of the teachers' questionnaire was also adopted from the teachers' questionnaire of DeJung and Duckworth (1985) which was a checklist table of ten teachers' comments referring to six different school codes on students' behavior. The teachers were asked to indicate whether they regarded a particular comment as appropriate for different school rules. The comments dealt with policy initiation, enforcement, and acceptance. In the current study, five out of these six rules are adopted. These rules were disruption of classroom instruction, being absent, being late, physical bullying, and eating during learning time. The sixth rule was omitted because it was not relevant to the variables that I am studying. Eight additional rules were designed according to the purpose of my study, based on my literature review, and relevant to the school discipline policies to be measured; these rules were as follows: using bad language, using cell-phone on school's premises, violating doing homework, not abiding by the dress code, chewing gum, cheating, vandalism, and smoking.

Since I increased the number of the rules to thirteen, I reorganized the shape of the second part of the teachers' questionnaire to make it clearer and even shorter in presenting the information by using a table form which helped the teachers link immediately their comments to the school rules. At the end of the teachers' questionnaire, the teachers were asked to add any additional information or comments at the back of the page; and they were thanked for their cooperation. 


\section{Students' Questionnaires}

In the current research, data from the Intermediate students' perceptions on the school discipline policy were attained by using a brief 21 questions two-page questionnaire. Twelve questions were adopted from the students' survey of DeJung and Duckworth (1985) because they fit well the purpose of my study. The questions clarified if there were errors in the enforcement of the school's rules by blaming the students for breaking rules when it wasn't their fault or by letting students get away with breaking some rules; or if students were not knowledgeable about the school's rules. They elicited students' perceptions of such enforcement.

In the current research, nine additional questions were designed to fit the purpose of my study. Six multiple choice questions were devised to collect more data on the variables of the current research. They included three questions on the students' safety; one asked the students if their parents received a copy of the school's rules at the time of their enrollment. Another asked if they received any training on the school's rules and its duration. One asked about the level of understanding of the school's rules. Three additional questions were designed according to the punishment used in the studied school: if they received oral, minor written or major written warnings, how often they received such warnings and for what reasons (see Appendix B).

\section{Students' questionnaire history.}

DeJung and Duckworth (1985) distributed the students' questionnaires to all students in their school site at the same time, just prior to their Spring break. For validity purposes, and as a step to standardize the procedure of their study, "the questionnaires were completed privately and anonymously in each student's classroom and then returned in sealed envelopes to the teacher for 
collection by a member of the research team" (p. 58). In the current research, same procedure has been followed (see Appendix B).

\section{Classroom Observation}

The observation sessions had been conducted in the playground, hallways and in all sections of the Intermediate classrooms during the students' academic, and activity hours, and during break time. These sessions were conducted to collect information on the similar concepts that were presented in the students' and teachers' questionnaires (Appendix $\mathrm{H}$ ), and on the alternative concepts that were only presented in the teachers' questionnaire (Appendix I) in order to achieve triangulation of information for all the concepts used. Also these sessions were used to collect data on the enforcement of the discipline policies by the teachers and by the administration. This was achieved by collecting data on the frequency of the students' violations of rules that were related to the research variables; and frequency of the teachers' reactions to these violations in order to compare these frequencies to each other. Also the review of the classroom agenda were done after each session to count the frequency of the teachers' reporting to the administration on the students' discipline violations which reflected the level of the enforcement of the school's discipline policies by the teachers. However, the level of the enforcement of the discipline policies by the administration was determined by comparing the data collected from the review of the personnel's discipline records with the frequency of the teachers' reporting on the students' discipline infractions. Also the ways of the administrative reactions to the students discipline violations were analyzed to verify whether such reactions were in harmony with the written codes. Therefore, observational checklists (Appendix C) were designed according to the research variables in table forms to facilitate the recording of the students' violations, the 
teachers' reactions and reporting of each discipline violation. However, the criteria of evaluation of the enforcement of the discipline policies were based on the five following levels: highly enforced, quite enforced, moderately enforced, slightly enforced, and not enforced. If the teacher reported between $90 \%$ and $100 \%$ of the students' discipline violations, the teacher got highly enforced; if the teacher reported on $70 \%$ to $89 \%$ of the students' discipline violations, the teacher got quite enforced; if the teacher reported on $40 \%$ to $65 \%$ of the students' disciplines violations, the teacher got moderately enforced; if the teacher reported less than $40 \%$, the teacher got slightly enforced; if the teacher didn't report any of the students' discipline violations, the teacher got not enforced . In addition, these same evaluation criteria were used in determining the level of the administrative reactions to the teachers' reported discipline violations of the Intermediate students.

The product that I got from the observational checklist was a combination of quantitative and qualitative information. The quantitative information helped in presenting the data collected from the classroom observation on the students' violations of the different research variables in each Intermediate level. However, qualitative interpretations were used to explain the quantitative information as a step to evaluate the enforcement of the different discipline rule.

During the observation, the research comments were quick notes or field jottings which helped me write more about the related subjects later on. Also, I used field notes and field diary. The field notes were used for the detailed notes of what I heard, saw, and experienced during the collection of data while the field diary reflected my feelings, opinions and perceptions about others with whom I came in contact during the course of observation. 
Appendix D presents the Buckley's Model on classroom rules establishment and enforcement which is very helpful in classroom observation. Therefore, I created a table that presents the different steps of Buckley's Model to check the enforcement of the thirteen school discipline rules (Buckley, 1977). Quantitative information were obtained from the Buckley's Model which helped me analyze the ways of school's rules enforcement and the way that is most used by teachers.

\section{Reviewing School's Documents}

I reviewed the schools' documents concerning the school's discipline policies, the students' referral records, and the personnel's discipline records. Reviewing these documents was essential for doing content analysis which helped me compare what was written on papers and what was applied on the ground; and the ways administrative personnel were handling every case of student's misconduct, misbehavior or breaking the school's rules. In addition, it helped me identify the departments that reinforced school's rules most.

Through investigating students' referral records, I was able to collect the following descriptive data:

- The number of students receiving differing numbers of referrals in order to compare it to the total number of the Intermediate students (see Table E1).

- The number and kind of students' referrals reported by each faculty member in order to compare between them and to identify who was reporting the higher or lower referrals by the teachers (see Table E2). 
- The number of referrals received by the students who committed the discipline violation(s) according to academic materials (see Table E3).

- The frequency of administrative reactions to rule infraction which reflected the seriousness of the administrator(s) towards the frequency of the students' referrals (see Table E4).

- The number of students' referral referrals in each Intermediate grades and sections to identify who was committing the highest discipline referrals between them (see Table E5).

- The frequency of different rule infractions resulting in warning to identify whether there is an alignment between written codes concerning warning and taking warning from cumulative referrals in classes (see Table E6).

- Higher or lower number of referrals and suspension rate received by each Intermediate level in order to find out which class or section received the higher or lower suspension rate (see Table E7).

- The consequences for cumulative warnings (see Table E8) which reflected the seriousness of the administrator in applying written codes (DeJung \& Duckworth, 1985).

These points were presented in a table forms (Appendix E) which helped in analyzing the enforcement of the school's discipline policies. Quantitative information was the product of reviewing students' documents which helped me also in further qualitative analysis.

\section{Procedures}

The procedure of my study (adopted from DeJung \& Duckworth, 1985) was divided into five phases. The first phase included the act of reviewing the school's discipline policies and analyzing its content through manifest and latent analysis. 
The second phase was the observation of Intermediate classes, hallways, and playground to collect data on the ways the teachers, staff, and administrators were handling the students' misconduct and how they are enforcing the school's rules on the ground. However, during the current research the information collected from the playground was recorded from the first floor, and sometimes on the entrance stairs near the small cafeteria which had made it possible to record what was really happening during the recess.

The data received from the Intermediate teachers' questionnaire (Appendix L, M, \& N) was obtained in the third stage of the current research; the questionnaires were delivered to all Intermediate teachers in the last week of the research. It was done just before the weekend vacation in order to provide sufficient time for the teachers' sample to respond privately and anonymously on the entire questionnaire. 19 envelopes containing each the teacher's questionnaire were delivered to the school's academic supervisor who in turn distributed them to the teachers' sample in order to assure the delivering of the questionnaires from an authority position, and to minimize the probability of refusing to respond on the questionnaire due to stress of work and lack of time. The teachers were requested to return their respondents copies in a sealed envelope in few days; and to return them to the academic supervisor who in turn delivered them to the researcher.

A total of 18 completed teachers' questionnaires were returned out of the 19 teachers' copies. Only one female teacher of the activity department refused to respond on the questionnaire due to lack of time and the stress of work. The returns provided $95 \%$ response rate with $5 \%$ rate of non-respondents on the teachers' questionnaires. 
The Intermediate teachers' perceptions of the effective enforcement of the school's discipline policies were obtained from a brief of 35 questions on one and a half page with both sides which represented the first part of the teachers' questionnaire, and a table form that reflected the teachers' comments on the 17 school's discipline rules as the research variables which represented the second part of the teachers' questionnaire. The teachers' responses on the questionnaire are presented in table form (Appendix $M \& N$ ) as well as the summary of these data (Appendix L). The first part of the teachers' questionnaire (Appendix M) collected information on eight main topics; six of which were the same topics in the students' questionnaires which were the communication of the school's discipline policies, the teachers' perceptions of the school's discipline policies, the involvement in the students' behavioral record, problems in the discipline enforcement, bullying problems, and the modifications needed in the school's discipline policies. The two additional topics were the teachers' satisfaction in such policies, and the teachers' tenure in the line of teaching. Three main topics which were the teachers' perceptions of the school's discipline policies, the problems in their enforcement, and the modification needed were more elaborated than the students' questionnaire with additional questions to have deeper understanding of the issues. The second part of the teachers' questionnaire (Appendix N) provided deeper understanding of the problems in three main topics: the enforcement of the school's discipline policies, the modification needed, and the teachers' perceptions of each of the 17 school's discipline policies.

The data received from the Intermediate students' questionnaire (Appendix J \& K) was obtained in the fourth stage of the current research which is the final stage. The students' responses are presented in table form (Appendix $\mathrm{K}$ ) as well as the summary of these data (Appendix J). The questionnaires were delivered to all Intermediate students during the same 
time, after the second recess, in the last day of the research. Six big envelopes containing copies of the students' questionnaires correspondent to the number of students in each Intermediate section were distributed by the school's academic supervisor to the classroom teachers of the Intermediate levels as a step to control the delivering of survey from authority position. The students' questionnaires were completed privately and anonymously by each Intermediate student; the survey lasted approximately 10 to 15 minutes. Each Intermediate student returned the completed questionnaire to the classroom teacher who was responsible for putting the questionnaires in the research envelop in order to confirm that all the classroom students delivered their copies. The six envelopes were collected personally by the researcher.

A total of 111 completed student's questionnaires were returned out of 112 students' copies; 42 copies from the Seventh grade (21 in section A, 21 in section B), 44 copies from Eighth grade ( 22 in section A, 21 in section B), and 26 copies from the Ninth grade (13 in section A, 13 in section B) with an estimate absence rate less than $1 \%$. Only one absent female student in the Eighth grade was observed during the delivering of survey; yet with the approval of the administration, the absent student completed the questionnaire in the following day after she returned to school during the recess which raised the total of completed student's questionnaires

to 112 . These returns provided $100 \%$ response rate with $0 \%$ rate of absence on the student's questionnaires.

The Intermediate students' perceptions of the effective enforcement of the school's discipline policies were obtained from a brief of 21 questions on one page with both sides. The questionnaire collected information on six main topics: the communication of the school's discipline policies, the students' perceptions of the school's discipline policies, students' 
behavioral records, problems in the discipline enforcement, bullying problems, and the modifications needed in discipline policies.

The teachers' and students' questionnaires were completed in the school. The total size of the sample was reported along with the overall percentage of returns. In addition, the percentage of the total sample responding for each question or item were reported in the analysis of both questionnaires. Finally, the percentage of respondents who chose each alternative for each question was also given during the analysis.

The last stage of the procedure of the current research was the review of the classroom agenda of all the Intermediate classes to record the teachers' frequencies of reporting to the administration on the students' discipline violations. In addition, the review of the personnel discipline records was done at the end of this stage to identify the frequencies and the percentages of the administrative reaction to the teachers' reported violations.

\section{Analyzing Data}

I used the content analysis to examine data from school's documents concerning the discipline policies, the students' referrals records, the personnel records of handling the policies' enforcement through punishment and sanctions. Based on the definition of Fraenkel and Wallen (2008), content analysis is a technique that allows researchers to study human behavior in an indirect way by analyzing communication. In doing the content analysis, the researchers can code either the manifest or the latent content of communication. The manifest content of communication refers to counting the frequency of certain words, phrases, or pictures which will provide the advantage of reliability, but it is suspected in terms of validity since the repetition of 
certain words would not indicate the degree of its development whereas the latent content of communication refers to the meaning underlying of what is said or shown which will provide the advantage of validity, but it is at the expense of reliability since each researcher may assess differently the degree of the development of a certain meaning. Therefore the best solution is to do both content of communication, if possible, which will provide some evidence of criterionrelated-validity and will add another advantage to the research (Tashakori, 1998).

The procedures of content analysis that were used in the current research were as follows. Manifest and latent content analyses were based on the above definition and on the objectives of my research questions in order to find the relationship to the research objectives which were the enforcement of school's discipline policies and the perceptions of students and teachers of such enforcement.

\section{Triangulation}

During observation, similar concepts between the students' and teachers' questionnaires were collected and presented in a clear table form (Appendix $\mathrm{H}$ ) to facilitate checking the triangulation of information between such concepts and the information collected during observation.

Therefore, criteria for evaluating these concepts based on observation were used (Appendix $\mathrm{H}$ ). Further triangulation was achieved by checking the alternative concepts that are only presented in the teachers' questionnaire and checked them during observation and during the review of school's discipline documents which were also presented in a table form (Appendix I) to facilitate checking the triangulation information between these alternative concepts and the information collected from observation and from the supervisors' questionnaire (Appendix S). 
Based on my second research question which included the perceptions of students and teachers of the enforcement of school's discipline policies, the relationship between each of the students and teachers questionnaires was related using the codes of research variables and themes to arrive at a narrative description of findings. Furthermore, comparison was used between the students' and teachers' questionnaires to identify the commonalities and differences of their opinions on the same concept. The commonalities were also compared to the information collected from observation session to achieve triangulation of data on the same concepts. The alternative concepts were presented in the teachers' questionnaires (Appendix I) such as perceptions of teachers of the school's discipline policies, the teachers' satisfactions with these policies, additional questions on the school's enforcement, and teachers' history. All of these questions were compared to the information received from the school's documents as well as to the information received from observation sessions.

\section{Checking Reliability and Validity}

Reliability is the consistency of the results or scores provided by a research instrument despite its administration to different individuals at different time, and in different location and circumstances whereas validity refers to the correctness, meaningfulness, and usefulness of the conclusions that the researchers make based on the collected data (Burns, 2000).

Therefore, for reliability purposes, the students' and teachers' questionnaires in the current research had been piloted on a small group of Lebanese students and teachers of the same age of the real sample. So, slight modifications of both questionnaires were made before they were administered to the actual sample. In both questionnaires, the modifications were in general for simplifying certain words by adding their meaning or synonyms between parentheses such as the 
word enforcement was explained as implementation. Also, the set of warnings such as the oral warning, the minor written warning, and the major written warnings were explained in Arabic between parentheses to make them clearer for the students' sample. In addition, the word bullied was explained as being afraid of someone who hurts you physically, verbally, or emotionally. Furthermore, the word bullying was explained as hurting others physically, verbally, or emotionally. Moreover, the word surveillance was explained as observation, inspection, or supervision. On the other hand, the modification in the teachers' questionnaire was by switching the word segregated to the word split; and to clarify the purpose of surveillance of school premises which was to control students' bullying. In addition, Arabic meanings for the three kinds of warnings were given between parentheses as in the students' questionnaire.

For validity purposes, the students' and teachers' questionnaires of the current research had been piloted on two expert people in the field of educational management before they were conducted to the actual sample in order to reveal defects in the research plan such as polishing the survey format, depicting misleading, or irrelevant questions, revealing ambiguities, poorly worded questions, questions that could not be understood, unclear choices, or unclear instruction to the participants in order to assure that the actual sample clearly understood the content and responded on all the questionnaire items (Travers, 2001).

The suggestions were that some modifications were needed; and the two external audits provided valuable feedback on the content of both questionnaires which helped in modifying before administering them to the real sample (see Appendix B).

Further modifications in the teachers' questionnaire were made to minimize misleading answers such as to re-arrange the expected answers of the question; to clarify difficult words; to 
eliminate unnecessary questions; to simplify the language of some questions; and to add questions that ensure the repetition of concepts in both questionnaires. In addition, the school's rules that were mentioned in the second part of the teachers' questionnaire were re-arranged for better and clearer presentation.

In the current research, procedures to enhance validity and reliability included: the triangulation of instruments which helped in comparing information on the same topic with different instruments, observing on daily basis the school classes, hallways, and playground over a period of three weeks provided consistency of information over time to depict reliable conclusions. Additional procedure was to interview informally the academic supervisor, the discipline supervisor, and the intermediate teachers more than once which helped in investigating the same concept from different perspectives.

\section{Controlling Internal Validity}

Based on the definition of Fraenkel and Wallen (2008), the internal validity means that any relationship observed between two or more variables is clear rather than being due to something else. Threats to internal validity could be differences in subject characteristics, mortality, location, instrumentation, testing, history, maturation, attitude of subjects, regression, and implementation. Therefore, the researchers tried as much as they can to control these threats by standardizing the conditions under which the study occurs; obtaining more information on the sample of the study; obtaining more information on the details of the study; and choosing an appropriate design. 
In the current research, the internal validity was controlled by triangulating the data (Appendix H \& I) by presenting the students' questionnaires to the teachers in order to get their feedback on its appropriateness for the students (DeJung \& Duckworth, 1985). Another controlling step was to train the teachers on administering the students' survey without providing them with the information they would need to distort the research results as a step to control the data collector bias and the attitude of the subjects. In addition, I controlled location, instrumentation, subject attitude, and implementation threats by standardizing the conditions of the study through three steps: the first one was to deliver the students' questionnaires at the same time on all the Intermediate levels with all their sections with the trained teachers (Bryman, 2001). The second one was to distribute the students' questionnaires by the school administrator to the teachers of the Intermediate levels each in their own classroom as a step to keep the location constant. The third one was to ask the students to complete the questionnaires privately and anonymously in their classrooms, and then return the completed questionnaires to their teachers to put them in sealed envelopes for collection by the researcher. Another step was to check the validity of my data collection by providing an external audit (DeJung \& Duckworth, 1985). Another step was to obtain more information from the supervisor on the extraneous school's events that may occur during the study in order to avoid delivering the students' and teachers' questionnaires on these occasions (Cohen, et al. 2000).

\section{Generalization}

Generalization means that the researchers try to apply the findings of a particular study to people or settings that go beyond the particular people or settings used in the study (Tashakori, 1998). Although, generalization was not an aim in my research, since it lacks randomization in 
selecting the school under study, and it was only conducted in one school setting. I hope that schools of similar contexts gain insight from the findings of the current research.

\section{Researcher's Role}

My role as a researcher was a non-participant observer who did not interfere or participate in any school's activities. The middle school members that were studied might, or might not, have realized that they were being observed in the hallways and in the playground since I acted as a visitor who was taking notes all the time. During recess, I tried to take the permission of the supervisor to be in the first floor, at the balcony in order to have the complete view of the playground. Yet in the classrooms' observation, I alerted the teacher beforehand and asked to be introduced as a visitor for a couple of weeks; and I sat in the back at one corner in order to minimize my influence as an observer. Then, I spent three to four days in the classroom before starting to fill the observational checklists in order to enable the students to become accustomed to my presence and go about their usual activities.

\section{Research Ethics}

The following ethics were considered in the current research: the identity of all the participants in the research was protected to ensure that none of the data collected will cause physical or psychological harm for them. Also, confidentiality and anonymity of the survey respondents and schools' name was assured. In addition, the participants were treated with respect, and they had the free will to participate in the survey. Furthermore, the permission for classroom observation was sought beforehand from the teacher(s). However, no hidden tape recorder was used. Moreover, there were willingness to share the final results of the study with 
the administrators of the school, and the school's permission for free publication was aiso requested (Fraenkel \& Wallen, 2008).

The previous sections presented the methodology used in the current research while the following chapter presents results of the research with the summary of each instrument. 


\section{Results}

Due to the length of the results from the different research instruments, summary of the results of each one are presented clearly in a table form as follows: Results of analyzing discipline policies using manifest analysis (see Appendix F), and latent analysis (see Appendix G); results of reviewing personnel's discipline records and students' referrals (see Appendix E). Data received from the students' questionnaire (see Appendix K) with the summary of its data (see Appendix J) are also presented. Data from the teachers' questionnaire in its first part (see Appendix M), and second part (see Appendix N) and the summary of data from the teachers' questionnaire (see Appendix L); and data of classroom, hallways, and playground observations are also presented in table forms according to research variables (see Appendix P).

\section{Summary of Results}

\section{Summary of manifest analysis of discipline policies.}

Based on the manifest content analysis of school's discipline policies, the research variables that were highly repeated were absenteeism, tardiness, and students' uniform while the research variables of disrupting others, violating doing homework, and students' hair were somewhat repeated. Students' bad language and vandalism were moderately repeated while using cellphone, chewing gum, eating during learning time, wearing jewelry, forgetting materials, smoking, cheating, and bullying others emotionally, verbally, and physically were slightly repeated. 


\section{Summary of latent analysis of discipline policies.}

Based on the latent analysis of the school's discipline policies (Appendix G) which included the handouts presented to students and parents and the personnel enforcement records, we could conclude that the two research variables that were very serious were cheating and smoking since they were stated with the consequence of suspension. Also, absenteeism, vandalism, and disrupting others were somewhat serious since they were stated with major and minor written warnings and sometimes with oral warnings. However, absenteeism was more serious than vandalism since absenteeism was stated with the consequences of two major written warnings, five minor written warnings, and one oral warning while vandalism was stated with the consequences of two major and one minor written warning. Disrupting others was stated with the consequences of one major written warning, three minor written warnings and two oral warnings. Moreover, using bad language, emotional, verbal, and physical bullying, uniform, and homework violation and tardiness were variables moderately warned since each was stated with the consequence of a major written warning or a combination of minor and oral warnings, but using bad language, emotional, verbal, and physical bullying were serious than others. Furthermore, using cell-phone, chewing-gum, eating during learning time, and forgetting materials were slightly serious since each was stated with the consequence of a minor written warning; wearing jeweiry was the least slightly serious since it was stated with the consequences of two oral warnings (Appendix G).

The consequences of cumulative referrals and warnings were presented clearly at the end of the documents of the discipline policies: referrals were recorded on the student's discipline records for four rule infractions of the same kind at the same material. In addition, a minor 
warning is provided for four oral warning whereas a major warning is provided for three minor written warnings and a letter is sent to parents. Moreover, a day of suspension is provided for two major written warnings; three days of suspension is provided for three major warnings. However, students were expelled after four major written warnings (see Table E8). Furthermore, a set of conditions were provided in the last paragraph of the documents of the discipline policies to eliminate different kinds of warnings from the students' discipline records (see Table E9).

Summary of reviewing school's personnel discipline records \& students' referrals.

A summary of the review of the school's personnel records concerning the referrals that the students committed from the beginning of the school year 2009 till the end of research (Appendix E) reflected that 45 students out of 112 Intermediate students or $40 \%$ of the students' sample received a total of 81 discipline referrals committed by 31 male and 14 female students (see Table E1).

Further analysis of the data from the personnel's discipline records reflected that $60 \%$ of the discipline referrals were for not doing homework whereas $23.5 \%$ referrals were for forgetting school's materials and $13.6 \%$ referrals for disrupting others in talking and laughing. A single referral corresponding to $1.2 \%$ was reported for eating in class, another one for cheating; and another one for uniform violation which was reported by the supervisor (see Table E2).

As for the warnings, the personnel's discipline records reflected four warnings. $25 \%$ were oral warning that was given for a male student in the Seventh grade for cheating in the exam and a letter was sent to his parent which reflected harmony with the written discipline codes. However, $75 \%$ of the warnings were for male students in the Ninth grade for disrupting others in talking 
and laughing; $50 \%$ of these warnings were major written warnings while $25 \%$ were minor written warnings. $25 \%$ of the major written warnings were given without any previous reported oral or minor written warnings. The other major written warning was given for the student after receiving a single referral and without any of previous oral or minor written warnings that were reported. However, the minor written warning was given after committing three referrals (see Table E6).

\section{Results of observation}

The data collected from the observation of playground, corridors, stairs, and Intermediate classrooms are presented as follows:

\section{Playground's data.}

Information was collected on the students' behavior during the morning assembly and the recess. During the morning assembly, students were monitored by both supervisors and teachers. The students were not allowed to talk or read during assembly and had to show respect for the Lebanese National Anthem and listen to the supervisors' daily preach concerning the students' expected behavior especially during the first few days after the school's entrance. The late comers were not allowed to enter the school's gate until the National Anthem ends. If the students were late more than $7: 35$, they had to pass by the supervisor's office to justify and take permission paper that was signed by the supervisor for the classroom teacher to admit them. Based on observation, the supervisor provided the late comers an entrance paper to class without recording the names of these students on their discipline documents since most of the tardiness 
reasons were from traffic jam due to the school location. In addition, the students' tardiness didn't exceed few minutes after ringing of the bell.

Based on observation, the majority of the students were on time on school premises; and they joined the morning assembly quietly. However, three violations of talking and disrupting others were committed by the Intermediate students (Table P3). Two of these violations were committed during the supervisor's preach in the morning assembly; and the two male students who committed the violation were reprimanded in front the students but the supervisor who holds a wireless microphone. The third violation was committed by a male Intermediate student in the Eighth grade who was prevented from entering his class for his bad behavior, but the student joined the class after promising that he would improve his behavior. Observations also showed that some Intermediate teachers were against reprimanding the students in front of their peers and believed that the supervisor was exaggerating in his reactions.

As a step to motivate the students to follow the school's policies, the school's corridors, stairs and the playground bulletin board were filled with announcements on the different school's rules and policies for corridors, stairs, morning assembly, playground, and staff classroom. The rules announcements were hung from the first day of school entrance; and they were big enough to be seen clearly by the reader and the title were bolded, underlined and in uppercase. Also the aim of each set of rules was stated below the title, and the rules were stated in clear points and in easy language to be understood by all students. The playground rules was stated to create a safe and pleasant environment within the school by preventing students from running, pushing, kicking or hitting each other while the staff classroom rules were stated to make the staff aware of the roles that they had to play in the implementation of the discipline policies. 
During the recess, the students were only supervised by one supervisor; and a staff member had to lock all the classes near the playground to prevent students from entering other classes as a step to minimize the incidence of stealing personal materials; and vandalizing the classroom materials. Sometimes, the classes near the playground were kept opened especially during the second recess which provided the opportunity for the Intermediate students to stay in groups in their classes talking and revealing their problems to their preferred teacher who acted as a counselor. This incidence was observed three times with the same teacher. On the other hand, none of the teachers or staff supervised the first floor whose classes were kept opened during recesses. Since the majority of the teachers were full-time members, all the teachers tried to capture few moments of relief during the recess by joining their peers in the teachers' room. This kept the supervisor alone during his tour in the playground.

Also during recess, the supervisor held his wireless microphone, and walked among the students in the playground from time to time; yet, he was not available all the time to do so; and he could not see all the places during his tour since the playground was surrounded by small walls that separated the basketball court from the classes which created small corridors that could hide what was happening behind these walls especially the corners of the playground.

\section{Corridors' data}

Observation of corridors reflected that the school followed the separation of students during recess based on their class levels. The preschool had a separate building and campus; the elementary students had to join the campus in the third floor; and the Intermediate and Secondary had to join in the basket ball court. Only the Ninth Intermediate students had to descend to the playground since their classes were in the first floor whereas the classes of the 
Seventh and Eighth grade were near the playground. Based on the corridors and stairs rules, the students were expected to ascend and descend quietly and in line without shouting or running; and they were not supposed to be outside their classrooms between classes' period when there was no break time. Also, physical bullying in corridors was not allowed, and litter must be thrown in the garbage bins found there.

Observation showed that descending and ascending happened quietly and in calm way with slight supervision; yet, two students violated the rule of corridors and stairs through pushing each other (see Table P4). The Physical bullying violation was reported by one of the staff member; and only one of these two students was called to the office of the academic supervisor who reprimanded him. The student said it wasn't his fault and that the other male students pushed him in the first place. However, the corridor violation was not recorded in the students' behavioral record. This reflected that despite the slight supervision of the corridors and stairs, the staff implemented the discipline policies in hallways when they were available; yet; the follow up procedure in recording the violation incident, and blaming the provoker of discipline problems were not enforced.

Observations also showed that the Intermediate students especially the Ninth grade abided by the rules of stairs and corridors. There was neither shouting nor running in these places. In addition, the corridors were clean all the time and none of the students were seen littering. However, few students were observed outside their classrooms between class periods but they were highly reprimanded by the supervisor who shouted at these students who immediately ran away to their classes. This reflected that the corridors and stairs rules were highly enforced by the school (see Table P4). 


\section{Classrooms' data}

The data collected from the observation of Intermediate classrooms reflected that at the beginning of the school year, 112 Intermediate students and 19 teachers received the discipline policies handout that stated the school's rules and the consequences of their violations. The discipline rules were highly posted outside the classrooms while the Intermediate classrooms provided the impression that these rules were only important outside the classrooms since the classroom rules were not hanged on any bulletin board of the Intermediate classes.

Further classroom observation reflected that the majority of the Intermediate students submitted to the supervisor the confirmed paper that was signed and dated by the students' parents that they had received the school's discipline policies. Only $22 \%$ of the Intermediate students were delayed in submitting it. However, due to the firm supervisor in presenting such paper, the delayed students submitted it in two days period. This reflected that the school communicated its discipline policies through written form to students and parents; and the administration insisted on having authentic evidence that the parents received such copy.

Moreover, the teachers reminded the students of the discipline policies after the summer vacations and in case of students' violation which reflected that the teachers could remind the students of their discipline policies throughout the school year based on the students' behavior. Further classroom data reflected that no training of the discipline policies was done in the school. In addition, no follow up procedures were done by the teachers to check the level of understanding of the school's discipline policies. Furthermore, neither the students nor the teachers were involved in the development of the school's discipline policies. However, the administration involved the teachers in the initiation and the enforcement of the discipline 
policies especially through the urgent meetings during the school year through which the teachers and the administrators discussed the cases of troublemakers to take the fair consequences; they were also involved in the deliberation sessions at the end of school year to take the decisions of excluding the troublemakers who had cumulative discipline violations.

As for the troublemakers, the school had excluded during the previous year five students at the Intermediate levels, three males and two females. In addition, many students who violated the discipline codes during the previous year had to sign a letter of commitment to abide by the school's discipline policies in order to be enrolled during the current year. As a result, there was less frequency of calling the teachers for urgent meetings on discipline problems. In addition, less discipline problems had occurred during the current year in comparison with that of the previous year.

Additional classroom observation reflected that the administrator insisted that the teachers had to use the classroom agenda to inform daily on the absent students, violations of the discipline policies, and on the learning objectives that the students had achieved during the session. If the teachers informed on the cases of discipline violations, the students who had violated the discipline policies were immediately subject to consequences since their violations were knowledgeable by the administration on daily basis. This was also proved during the review of the classrooms' agenda, since the administrator wrote a short memo to a teacher that he/she had to use the classroom agenda in an efficient way to reflect what was really happening during the class session.

Moreover, some teachers who informed on the students' discipline violations were involved in providing the troublemakers with oral warnings, minor, and major written warnings. 
Moreover, the majority of the discipline warnings that were provided to the Intermediate students in the previous school year were on bad behavior, talkativeness and laughing for no reason which could cause disruption of explanation and cause delay in finishing the specified learning objectives on time. However, based on observation the students' misbehavior that caused the most stress for the Intermediate teachers was laughing for no reason and talkativeness.

Additional observation reflected that only the supervisor entered classes anytime during the morning while checking the students' absenteeism; and such class cuts lasted less than one minute which didn't affect any delay in the educational program. In addition, the Intermediate teachers didn't commit class cuts to each other which reflected that the Intermediate teachers abided by the staff rule that was implemented by the school.

As for the students' discipline violations in the Intermediate classrooms, the data collected reflected that 10 Intermediate students corresponding to $9 \%$, four females or $4 \%$ and six males or $5 \%$ out of the 112 students' sample were recorded as late comers; yet, they all followed the tardiness procedures by getting the supervisor's approval before entering to their classes (Appendix C). Therefore, the tardiness rule was highly implemented and enforced by the supervisor and by the teachers.

As for absenteeism, the administration had to report daily to the Lebanese Health Ministry about the number of the absent students and the reasons of their absenteeism as a precaution from the virus HIN1. Therefore, the administration highly supervised the classes on daily bases to be knowledgeable about the students' absenteeism. Therefore, each classroom teacher checked attendance at the beginning of the period daily followed by that of the supervisor to record the absence incidence on the student's record. The data collected from the observation session are 
presented in table form according to the research variables and according to their occurrence (see Appendix P).

Summary of students' discipline violations based on observation.

As a summary, classroom data reflected that the Intermediate students committed 953 discipline violations; 686 of these discipline violations (72\%) were committed in classrooms whereas 267 discipline violations ( $28 \%$ ) were committed in the playground (Table 38 ); that is more discipline violations in the classrooms than in the playground. The classroom and playground discipline violations of the Intermediate students are presented clearly in table form (see Table 38).

Table 38 reflected that the Intermediate students didn't meet the teachers' expectations about obeying discipline rules despite that $56 \%$ of the respondent teachers believed that it was very important for the students to have the initiatives to abide by the discipline rules.

Also Table 38 reflected that more surveillance was needed in the classrooms and in the playground especially near the canteen, in the bathrooms, and in the hidden areas near the corner of playground to control students' bullying.

Based on observation, the school didn't need adult hall monitors since the Intermediate students committed only four discipline violations in the hallways (Table 4) out of 953 total discipline violations (Table 38). Therefore, the playground and the classroom discipline violations could be controlled by using additional supervision from the first floor with the assistant of a staff member. 


\begin{tabular}{|c|c|c|c|c|c|c|}
\hline \multicolumn{7}{|c|}{$\begin{array}{l}\text { Table } 38 \\
\text { Summaries of Intermediate Discipline Violations }\end{array}$} \\
\hline & \multicolumn{2}{|c|}{ Classroom Violations } & \multicolumn{2}{|c|}{ Playground Violations } & \multicolumn{2}{|c|}{ Total Violations } \\
\hline & Frequency & Percentage & Frequency & Percentage & Frequency & Percentage \\
\hline Disrupting others & 321 & $33.7 \%$ & 5 & $0.5 \%$ & 326 & $34.2 \%$ \\
\hline Jewelry & 126 & $13.2 \%$ & 11 & $1.2 \%$ & 137 & $14.4 \%$ \\
\hline Homework & 80 & $8.4 \%$ & & & 80 & $8.4 \%$ \\
\hline Emotional bullying & 37 & $3.9 \%$ & 2 & $0.2 \%$ & 39 & $4.1 \%$ \\
\hline Hair Style & 33 & $3.5 \%$ & 3 & $0.3 \%$ & 36 & $3.8 \%$ \\
\hline Verbal Bullying & 21 & $2.2 \%$ & 41 & $4.3 \%$ & 62 & $6.5 \%$ \\
\hline Tardiness & 14 & $1.5 \%$ & & & 14 & $1.5 \%$ \\
\hline Forgetting books & 12 & $1.3 \%$ & & & 12 & $1.3 \%$ \\
\hline Absenteeism & 10 & $1 \%$ & & & 10 & $1 \%$ \\
\hline Uniform & 7 & $0.7 \%$ & 3 & $0.3 \%$ & 10 & $1 \%$ \\
\hline Eating in classroom & 6 & $0.6 \%$ & & & 6 & $0.6 \%$ \\
\hline Vandalism & 5 & $0.5 \%$ & 113 & $11.9 \%$ & 118 & $12.4 \%$ \\
\hline Bad Language & 5 & $0.5 \%$ & 6 & $0.6 \%$ & 11 & $1.1 \%$ \\
\hline Physical bullying & 4 & $0.4 \%$ & 85 & $8.9 \%$ & 89 & $9.3 \%$ \\
\hline Chewing gum & 2 & $0.2 \%$ & & & 2 & $0.2 \%$ \\
\hline Cheating & 1 & $0.1 \%$ & & & 1 & $0.1 \%$ \\
\hline Cell-phone & 0 & $0 \%$ & & & 0 & $0 \%$ \\
\hline Smoking & 0 & $0 \%$ & & & 0 & $0 \%$ \\
\hline General Total & 686 & $72 \%$ & 267 & $28 \%$ & 953 & $100 \%$ \\
\hline
\end{tabular}

As a summary of the reactions of the teachers to the discipline violations of the Intermediate students (Table 39), the classroom data reflected that the Intermediate teachers' highly reacted to students' tardiness, forgetting books, absenteeism, and cheating since the teachers reported to the administration on every students' violations through the use of classroom agenda. In addition, the teachers quite reacted to students' violations of not doing homework and eating in classroom 
rules. Moreover, the teachers moderately reacted to students' vandalism violations, emotional, verbal, and physical bullying, and classroom disruptions by providing oral comments sometimes in loud voice, and by using eye contact or body language. Despite such reactions in classroom, the teachers only reported to the administration on $3.4 \%$ of the total disrupting infraction. In addition, none of the emotional, verbal, and physical bullying violations nor the vandalism infractions were reported to the administration since the Intermediate teachers believed that they had solved the problems spontaneously. Table 39 also reflected that the teachers slightly reacted to hair style violations (Table P23) either by providing oral comments or using deduction points of the total student's grade; and none of these hair violations were reported to the administration. This reflected that the teachers slightly enforced the rules related to disrupting others and vandalism, hair code, and physical bullying. Further classroom data also reflect that the teachers didn't reacted to or reported on any of the students' violations of uniform, wearing jewelry, and the use of bad language which reflected that these rules were least effectively implemented by the Intermediate teachers (see Table 39).

Moreover, the supervisor slightly enforced the rules against vandalism, wearing jewelry, verbal and physical bullying since the majority of violating such codes was not seen by the supervisor due to the lack of assistant supervision during the recesses especially near the canteen and in the corners of the playground which resulted in lack of reporting on the students' bullying and vandalism violations during the recesses. In addition, the supervisor only reacted to two vandalism violations corresponding to $1.8 \%$ of vandalism violations committed in the playground (Table P2). The first reaction to the vandalism violations was when the supervisor prevented the Intermediate students from entering the garden area as a punishment for damaging the garden barrier; as a result, such reaction was considered as a general punishment on all the 
Intermediate students for vandalizing the school's properties. Therefore, the vandalism code was not fairly enforced. As for the supervisor's reaction to the students' verbal bullying, a male Eighth grader informed the supervisor that he was verbally bullied from another male student during the recess; yet, the supervisor only deprived the bullied from the recess, and kept him in his office for the rest of the recess time without recording the violation on the bullied discipline record. Therefore, the supervisor used time-out punishment on the student's verbal bullying (Table P2). As for the reaction to the students' physical bullying, the supervisor reprimanded one out of the two students who were pushing each other while descending to the recess (Table P4). However, the physical bullying was not recorded on the students' discipline record and the provoker of the discipline problem was not blamed. Therefore, the code that prevented the students' physical bullying was not fairly enforced. As for the reaction on the students' violations of wearing jewelry, one of the supervisor reacted to a single violation out of 11 jewelry violations committed in the playground corresponding to $9.1 \%$ (Table P3) and reminded the student who was wearing jewelry of the school's discipline related code without recording the violation on the student's discipline record. This reflected that the jewelry code was not fairly enforced by the supervisor. However, the academic supervisor had a desk drawer filled with many kinds of bracelet and necklaces which reflected that the academic supervisor was highly enforcing the jewelry code. Nevertheless, this controversy in the enforcement of the jewelry code would create confusion to the students which could lead to violate the jewelry code.

Furthermore, the majority of the violations of using bad language and emotional bullying were not heard or seen by the supervisor due to lack of assistant supervision during recess; As for other students' violations, none of the students' hair style violations whether the three violations that were committed in the playground or the 33 hair style violations that were 
recorded in the Intermediate classrooms (Table P23) were recorded on any student's discipline record which reflected that the supervisor was lenient in the enforcement of the hair style code (see Table 39).

Table 39

Summaries of Teachers ' \& Supervisors ' Reactions on Discipline Violations

\begin{tabular}{|c|c|c|c|c|c|c|c|c|}
\hline & $\begin{array}{l}\text { Classroom } \\
\text { Violations } \\
\text { Frequency }\end{array}$ & $\begin{array}{l}\text { Teachers' } \\
\text { Reactions } \\
\text { Frequency }\end{array}$ & $\begin{array}{c}\text { Percentage } \\
\text { of Teachers' } \\
\text { Reactions }\end{array}$ & $\underline{\text { ETR }}$ & $\begin{array}{l}\text { Playground } \\
\text { Violations } \\
\text { Frequency }\end{array}$ & $\begin{array}{c}\text { Supervisors' } \\
\text { Reactions } \\
\text { Frequency }\end{array}$ & $\begin{array}{l}\text { Percentage of } \\
\text { Supervisors } \\
\text { Reactions }\end{array}$ & ESR \\
\hline Tardiness & 14 & 14 & $100 \%$ & 1 & - & - & - & - \\
\hline $\begin{array}{l}\text { Forgetting } \\
\text { books }\end{array}$ & 12 & 23 & $100 \%$ & 1 & - & - & - & - \\
\hline Absenteeism & 10 & 10 & $100 \%$ & 1 & - & - & - & - \\
\hline Cheating & 1 & 1 & $100 \%$ & 1 & - & - & - & - \\
\hline Cell-phone & 0 & - & - & 1 & 0 & - & - & 1 \\
\hline Smoking & 0 & - & - & 1 & 0 & - & - & 1 \\
\hline Homework & 80 & 59 & $74 \%$ & 2 & - & - & - & - \\
\hline Eating in class & 6 & 5 & $90 \%$ & 2 & - & - & - & - \\
\hline $\begin{array}{l}\text { Emotional } \\
\text { bullying }\end{array}$ & 37 & 17 & $46 \%$ & 3 & 2 & 0 & $0 \%$ & 5 \\
\hline $\begin{array}{l}\text { Verbal } \\
\text { Bullying }\end{array}$ & 21 & 14 & $66 \%$ & 3 & 41 & 1 & $2.4 \%$ & 4 \\
\hline Vandalism & 5 & 3 & $60 \%$ & 3 & 113 & 2 & $1.8 \%$ & 4 \\
\hline $\begin{array}{l}\text { Physical } \\
\text { bullying }\end{array}$ & 4 & 2 & $50 \%$ & 3 & 85 & 2 & $2.4 \%$ & 4 \\
\hline Chewing gum & 2 & 1 & $50 \%$ & 3 & - & - & - & - \\
\hline $\begin{array}{l}\text { Disrupting } \\
\text { others }\end{array}$ & 321 & 143 & $34 \%$ & 4 & 5 & 5 & $100 \%$ & 1 \\
\hline Hair Style & 33 & 2 & $6 \%$ & 4 & 3 & 0 & $0 \%$ & 5 \\
\hline Bad Language & 5 & 0 & $0 \%$ & 5 & 6 & 0 & $0 \%$ & - \\
\hline Jewelry & 137 & 0 & $0 \%$ & 5 & 11 & 1 & $9.1 \%$ & 4 \\
\hline Uniform & 7 & 0 & $0 \%$ & 5 & 3 & 1 & $33 \%$ & 3 \\
\hline General Total & 686 & 161 & $24 \%$ & 4 & 269 & 11 & $4.1 \%$ & 4 \\
\hline
\end{tabular}

Note . ETR = Evaluation of Teachers' Reactions; ESR = Evaluation of Supervisors' Reactions. The percentages are calculated by 
dividing the frequency of students' violations by the frequency of teachers' or supervisors' reactions. (Evaluation Criteria: $1=$ Highly Enforced; 2 = Quite Enforced; 3 = Moderately Enforced; 4 = Slightly Enforced; $5=$ Not Enforced).

As for fair or strict enforcement of the school's discipline policies, additional classroom observation reflected that $79 \%$ of the Intermediate teachers were strict and fair in the enforcement of the school's discipline policies because they informed the administration of all the students' discipline violations which reflected consistent enforcement of school's discipline rules. However, $21 \%$ of the Intermediate teachers were lenient in such enforcement because they either didn't report on the students' discipline infractions or they reported on some students' violations which weakened the consistency of discipline enforcement, and helped some students get away with breaking rules especially the rules related to class disruption, students' hair style, wearing jewelry, emotional bullying, verbal bullying, physical bullying, using bad language, and vandalism. In addition, the Intermediate teachers were highly strict in the enforcement of the rules related to tardiness, absenteeism, forgetting books, and cheating since the teachers reported to the administration on every violation that was committed by the Intermediate students through the classroom agenda (Table 39). Only one teacher hesitated few days before reporting on cheating incident; yet, later on he/she revealed such violation to the administration which resulted in a consequence that was in harmony with the school's discipline codes. Further classroom observation reflected that the teachers were quite strict in the enforcement of some discipline rule while they were lenient in the enforcement of other rules (see Table 39).

Based on observation, $79 \%$ of the Intermediate teachers were fair in the enforcement of the discipline policies since they reported to the administration on all the students' discipline violations without discriminating between the female and male students whether these students 
were from higher or lower Intermediate levels. However, $21 \%$ of the Intermediate teachers were not fair in the enforcement of the discipline policies when they tended to report less on the students whose parents or relatives had power position in the school.

Further classroom observation reflected that in two incidents the students were blamed when it was not their fault, one incident of physical bullying in the school corridor (Table P4) and the second incident when the teacher reported only on the violation of eating in classroom (Table P35) without reporting on the other discipline violations. In both situations the provoker of the discipline violation was not blamed. This would create a sense of being blamed when it was not the students' fault.

As a summary of the administrative reactions on the teachers' reporting of the students' discipline violations, Table 40 reflects that the administration provided 80 referrals to 119 discipline violations that were reported by the teachers on the Intermediate students corresponding to $67 \%$ of the teachers' reporting on the students' discipline violations. This reflected that the administration moderately reacted to the teachers' reporting on the students' discipline violations. Table 40 also shows that the low frequency of the students' violations of chewing gum and the immediate reaction of the teacher to such violations reflected that the administration highly enforced the code of chewing gum (Table P36). Moreover, there were neither students' violations of using cell-phone nor smoking violations (Table 40), the evaluation of the administrative reactions to the violations of such variables was based on the information of the previous year which was also provided by the students' answers to the questionnaires that the administration provided oral warning for smoking within the school's premises whereas it provided written warning for the use of cell-phone in addition of taking away the cell-phone for 
the rest of the school year (Appendix $\mathrm{K}$ ) which reflected that the administration highly reacted to the students' violations of using cell-phone and smoking. Therefore the administration most effectively implemented the discipline codes of tardiness, absenteeism, and uniform, disrupting others, eating in classroom, chewing gum, using cell-phone and smoking.

Furthermore, the supervisor provided an oral warning for the student who committed cheating and a letter was sent to his parents; yet he was not suspended as the code of cheating stated. In addition, the administration reacted to $83 \%$ of forgetting books infractions (Table P21) and to $81 \%$ of the violations of not doing homework (Table P15). This reflected that the administration reacted to the students' violations of forgetting school's books, doing homework and cheating (Table 40).

Furthermore, the administration moderately enforced uniform whereas it was lenient in the enforcement of the discipline rules related to the students' vandalism, verbal bullying, hair style, and wearing jewelry since the administration didn't provided any discipline referral for any Intermediate student for the violations of such codes (Table 40).

As for vandalism, the administration didn't provide vandalism referrals to those students who were responsible for damaging the garden barrier (Table P34) and the supervisor punishment was not in harmony with the punishment stated in the discipline codes. As for the students' verbal bullying, the supervisor didn't record any referral despite that he was informed by the bullied about the verbal bullying incidence in addition of providing a lenient punishment to the bullied by depriving the bully from the time left of the recess without recording the verbal bullying violation on the bully discipline record (Table P29). As for the students' hair style, the administration didn't provided any referral for the 36 hair style violations of the Intermediate 
students for using hair gel (Table P23) despite that these violations were recognized during the morning assembly which reflected that the administrator was lenient in the implementation of the hair code. In addition, the administration didn't provide any referral for wearing jewelry (Table P24); although the academic supervisor took away the jewelry of a female Eighth grader in addition of having many students' jewelry in the administrative office ; yet; the Intermediate students get away 137 times from breaking the jewelry code by wearing bracelets, necklaces, and even of the religious kinds. Therefore, the administration didn't enforce the discipline rules related to vandalism and verbal bullying due to lack of supervision and monitoring students during recess; in addition of not enforcing students' hair style, and wearing jewelry. This reflected that the codes of vandalism, verbal bullying, hair style, and wearing jewelry were the least effectively implemented by the administration.

Table 40 also reflected that the administration didn't respond to any of the students' emotional bullying (Table P27), physical bullying (Table P31) and using bad language (Table P32) perhaps due to the lack of assistant supervision in the playground especially near the canteen which caused lack of reporting on such violations.

Based on observation, $16 \%$ of the Intermediate teachers wasted more than $20 \%$ of the learning time on the enforcement of the school's discipline policies whereas $84 \%$ of the teachers wasted less than $10 \%$ of the learning time on such enforcement. Further analysis of Table 40 reflected that the school was facing lack of supervision especially in the playground during recess which caused lack of reporting on the students' discipline violations. 


\section{Table 40 \\ Summary of Discipline Policies Enforcement on Intermediate Students}

\begin{tabular}{|c|c|c|c|c|c|c|c|c|c|c|c|}
\hline Discipline Rule & $\underline{\text { FSV }}$ & ¿ & 오 & FTR & $\underline{\text { FTRG }}$ & $\underline{\text { PTRG }}$ & $\underline{\text { ETRG }}$ & $\begin{array}{l}\text { Number of } \\
\text { Referrals }\end{array}$ & $\begin{array}{l}\text { Number of } \\
\text { Warnings }\end{array}$ & $\underline{\text { PAR }}$ & $\underline{\text { EAR }}$ \\
\hline Cell-Phone & 0 & 0 & 0 & - & - & - & 1 & 0 & 0 & - & 1 \\
\hline Smoking & 0 & 0 & 0 & - & - & - & 1 & 0 & 0 & - & 1 \\
\hline Tardiness & 14 & 9 & 5 & 14 & 14 & $100 \%$ & 1 & 0 & 0 & $100 \%$ & 1 \\
\hline Absenteeism & 10 & 6 & 4 & 10 & 10 & $100 \%$ & 1 & 0 & 0 & $100 \%$ & 1 \\
\hline Cheating & 1 & 1 & 0 & 1 & 1 & $100 \%$ & 1 & 1 & 1 Oral & $85 \%$ & 2 \\
\hline $\begin{array}{l}\text { Eating in } \\
\text { Classroom }\end{array}$ & 6 & 2 & 4 & 5 & 1 & $17 \%$ & 2 & 0 & 0 & $0 \%$ & 1 \\
\hline $\begin{array}{l}\text { Disrupting } \\
\text { Others }\end{array}$ & 326 & 252 & 74 & 143 & 11 & $3.4 \%$ & 4 & 11 & $\begin{array}{l}2 \text { Major } \\
1 \text { Minor }\end{array}$ & $100 \%$ & 1 \\
\hline Chewing Gum & 2 & 1 & 1 & 1 & 0 & $0 \%$ & 3 & 0 & 0 & $0 \%$ & 1 \\
\hline Uniform & 10 & 6 & 4 & 0 & 0 & $0 \%$ & 5 & 1 & 0 & $75 \%$ & 3 \\
\hline Forget Books & 12 & 6 & 6 & 23 & 23 & $100 \%$ & 1 & 19 & 0 & $83 \%$ & 2 \\
\hline Homework & 80 & 53 & 27 & 59 & 59 & $74 \%$ & 2 & 48 & 0 & $81 \%$ & 2 \\
\hline Jewelry & 137 & 78 & 59 & 0 & 0 & $0 \%$ & 5 & 0 & 0 & $23 \%$ & 4 \\
\hline Vandalism & 118 & 98 & 20 & 0 & 0 & $0 \%$ & $* 4$ & 0 & 0 & $0 \%$ & 4 \\
\hline Verbal Bullying & 62 & 61 & 1 & 14 & 0 & $0 \%$ & 5 & 0 & 0 & $0 \%$ & 4 \\
\hline Hair Style & 36 & 35 & 1 & 1 & 0 & $0 \%$ & 4 & 0 & 0 & $0 \%$ & 5 \\
\hline $\begin{array}{l}\text { Physical } \\
\text { Bullying }\end{array}$ & 89 & 74 & 15 & 0 & 0 & $0 \%$ & *4 & 0 & 0 & $0 \%$ & 4 \\
\hline $\begin{array}{l}\text { Emotional } \\
\text { Bullying }\end{array}$ & 39 & 30 & 9 & 17 & 0 & $0 \%$ & 5 & 0 & 0 & $0 \%$ & \\
\hline Bad Language & 11 & 11 & 0 & 0 & 0 & $0 \%$ & 5 & 0 & 0 & $0 \%$ & - \\
\hline Total & 953 & 723 & 230 & 278 & 119 & $12.5 \%$ & 4 & 80 & 4 & $67 \%$ & 3 \\
\hline
\end{tabular}

Note. $\hat{\delta}=$ Male $; \phi=$ Female $;$ FSV = Frequency of Students' Violations; FTR = Frequency of Teachers' Reactions; PTRG = Percentage of Teachers' Reporting; ETRG $=$ Evaluation of Teachers' Reporting; PAR = Percentage of Administrative Reactions on students' reported violations; EAR = Evaluation of Administrative Reactions on the students' reported violations. (Evaluation Criteria: 1= Highly Enforced; 2 = Quite Enforced; 3 = Moderately Enforced; 4 = Slightly Enforced; 5= Not Enforced). 
Also the philosophy of managing students' discipline of some of the teachers was not in harmony with that of the school which caused less effective implementation of the school's discipline policies and caused shortage of reporting on the students' discipline violations in the classrooms. In addition, part of the teachers had problems of classroom management which caused problems of wasting part of the students' learning time.

\section{Summary of data from the teachers' questionnaire.}

As a summary of the data received on the school's communication of their discipline policies; the majority of the teachers had received the school's discipline policies booklet at the beginning of the year and agreed that the school communicated its discipline policies to students and parents through handbook and newsletters. Half of the teachers responded that they reminded their students after the vacations whereas the other half believed that they reminded their students throughout the year and whenever there was a need of their discipline policies. Furthermore, the majority responded that they considered revising the school's discipline rules based on the students' behavior.

The teachers' perceptions concerning the students' understanding of their discipline rules, the quantity of these rules, and the students' involvement in the development of these rules showed the following: The majority of the teachers believed that the students understand clearly the discipline rules whereas some minority had opposite opinions on such issue because they believed that the students tried to forget the rules from time to time; the students usually think the rules were out dated and not to be applicable; and some rules need deep understanding from students and parents. In addition, the majority of the teachers believed that the school didn't have too many rules. Further data revealed that less than half of the teachers never involved students 
in the development of classroom rules whereas more than quarter of the teachers involved sometimes students in such matter. Some teachers responded that they generally involved students in the development of classroom rules.

Moreover, data concerning the consistency and the fair implementation of the discipline policies reflected that the majority of the teachers were strict in enforcing the rules related to cheating, vandalism, using bad language, and oral bullying. In addition, less than two third of the teachers were strict in enforcing the rules related to eating in class, smoking, not doing homework, disrupting others, and using cell-phone on school premises. However, one third of the teachers were strict in enforcing rules related to uniform, tardiness, hair code, jewelry, and absenteeism. Also in consistency, one fifth of the teachers were lenient in absenteeism and tardiness whereas one tenth of the teachers were lenient in enforcing dress code concerning hair, jeweiry, and uniform. However, small minority of the teachers were lenient with the rule of not doing homework, disrupting others, chewing gum, physical and emotional bullying. Further data on consistency revealed that more than half of the teachers believed that the enforcement of the rules related to vandalism, oral and emotional bullying were the staff's business. Half of the teachers believed that the rules related to cheating, physical bullying, and the dress code of hair, jewelry, and uniform were also the staff business to enforce. Moreover, two fifth of the teachers believed that the rules related to cell-phone, using bad language, chewing gum, and smoking were the business staff to enforce. Furthermore, more than one third of the teachers believed that the rules related to absenteeism, tardiness, not doing homework, disrupting others and eating in class were the total staff business to enforce. In checking the fair implementation of discipline rules, less than one third of the teachers believed that the students got away with violating the jewelry code and uniform. In addition, more than two fifth of the teachers believed that the 
students got away with breaking the rules related to tardiness, not doing homework, disrupting others, cheating, chewing gum, all kinds of bullying, physical, emotional, and oral. However, less than one fifth of the teachers believed that the students got away with violating the rules related to using bad language, using cell-phone, eating in class, and vandalism. Only one fifth of the teachers believed that the students got away with breaking absenteeism rule.

Further data on the teachers' perceptions concerning the personnel's expectations of obeying rules revealed that more than half of the teachers believed that it was very important for the students to make their own decisions about obeying rules. However, less than two third of teachers believed that it was moderately important for the students to make such decisions whereas small minority believed that it was not an important issue to learn. Moreover, one fifth of the teachers believed that all the discipline policies were effectively implemented. However, all the other respondents believed that the discipline procedures were extremely effective such as punishing impolite students by sending them home, warnings, and deliberation session to exclude the misbehavior students at the end of school year; in addition of using the notes on the class agenda on misbehavior students and sending it to the academic supervisor on daily basis.

As for the teachers' satisfaction with the implementation of the discipline policies, the teachers' responses reflected that more than half of them fully approved the school philosophy regarding the management of the students' discipline, and they were undivided in their agreement with the administrator's management. Also they fully supported the school's procedures concerning discipline rules. The rest of teachers partially approved of the school philosophy, and they were nearly undivided in their agreement with the administrator's management as well as they partially supported the discipline procedures. Very small minority 
minimally approved the school discipline philosophy; in addition of being split in their agreement with the administrator's management, and they minimally supported the discipline procedures. Concerning the teachers' involvement in the development of the discipline policies, the majority of the teachers responded that they were not involved in such development. In addition, less than half of the teachers preferred to be more involved in the decision on discipline policies whereas less than half of the teachers prefer not to interfere in such decisions. However, the majority of teachers were satisfied with the implementation of discipline policies; yet, a small minority believed that stronger punishment was required and certain discipline cases needed to be fully considered promptly by the administration.

As for the teachers' perceptions concerning being involved in providing oral, minor written or major written warnings, the majority of the teachers revealed that they were not involved.

However, more than two fifth of the Intermediate teachers were involved in providing the middle school students with oral warnings for many reasons. The reasons for providing oral warnings are presented in a descending order (Appendix $\mathrm{M}$ ) based on the frequency of similar responses: bad behavior was mentioned eight times; lack of attention was mentioned six times; delay and sportswear were mentioned four times; ethical, moral, and social reasons were mentioned three times; and talkativeness was mentioned two times only. Further analysis of the data reflected that less than one third of the teachers were involved in providing the Intermediate students with minor written warnings for the following reasons: misbehavior and laughing without a reason were mentioned five times; not doing homework and not studying were mentioned three times; and lack of attention was mentioned a single time. Additional analysis of the data reflected that less than one fifth of the teachers were involved in providing major written warnings for the following reasons: Laughing and talking, and unchangeable bad behavior. 
Further data received from the teachers' questionnaire on the problems in the enforcement of discipline policies reflected that more than one tenth of the teachers believed that none of the discipline policies were least effectively implemented. However, more than one third of the teachers believed that there were problems in the implementation of some discipline policies; yet, there was no agreement on a specific discipline policy; and each teacher provided different comment such as monitoring students during recess, dress code, all discipline rules, political issues, suspending students for few days, tardiness procedures delayed entering students to their classes, and standing with the students more than teachers in discipline problems. Further data on the problems in the enforcement of discipline policies reflected that the majority of the teachers believed that the students' misbehavior caused them stress; yet, in determining the specific students' misbehavior that caused them the most stress, the teachers provided different comments. More than one fifth of the teachers believed that talking in class during explanation caused them the most stress whereas more than one tenth of teachers believed that the most stressful misbehavior was the students' disrespect to teachers and being impolite. In addition, more than one tenth of the teachers believed that disruptive and hyper behavior especially with young students caused them the most stress. However, the remaining teachers' provided each different comment such as laughing for any reason, students' delay and disrupting class work, hyperactivity and cheating. Another teacher believed that the students' discussing current political issues caused the most stress for him/her. However, another teacher believed that students' talkativeness, wasting time during explanation, cheating, carelessness, taking a lot of permissions to go out, and not following instruction to do homework caused the most stress for $\operatorname{him} /$ her. 
Further summary of the problems of the enforcement of discipline policies reflected that less than two third of the teachers believed that the discipline problems were decreasing in the last couple years whereas more than one third of the teachers believed that the number of discipline problems was the same as before. However, less than of fifth of the teachers believed that the discipline problems were increasing. Further data on the problems in the discipline policies reflected that more than one third of the teachers believed that the class delay in program was the same as in previous years while less than one third of the teachers believed that there was less class delay in program as before. However, a small minority of teachers believed that class delay was increasing as from previous years. In addition, more than one third of the teachers believed that the number of class cuts were the same as the last couple years whereas more than one third of the teachers believed that the number of class cuts was decreasing. However, a small minority of teachers believed that the number of class was increasing. Further data reflected that more than half of the teachers believed that the students' discipline was a minor problem in the school whereas less than two fifth of the teachers that the students' discipline was not a problem. However, a small minority believed that students' discipline was a major problem in the school. Moreover, additional data reflected that the majority of the teachers believed that managing students' discipline in their classes took less than $10 \%$ of their class time whereas one fifth of the teachers believed that the time wasted on managing students' discipline took $10 \%$ of their class time. However, a small minority of the teachers believed that the time wasted on students' discipline took more than $20 \%$ of their class time. Further data reflected that a small minority of the teachers believed that bullying rules concerning physical, emotional, and oral bullying rules were causing more problems than solving them. 
Concerning the bullying problems, more than two third of the respondent teachers believed that they didn't have bullies in their classes whereas less than one third of the teachers believed that they had. In addition, more than two third of the teachers replied that that none of the students contacted them in case of bullying while less than two fifth of the teachers answered that the students contacted them in bullying cases. However, less than three quarter of the teachers who responded positively reflected on the ways they treated the bullies and the bullied and the others didn't provide any comments on the bullying treatment. Only two teachers reflected that after being informed of the bullying cases, they investigated on the problem; helped and comforted the bullied, and they provided oral warning for the bully to realize his mistake. If the bullying cases were repeated, they informed the administration. The rest of the teachers who were informed of bullying cases provided different comments in handling the problems. One of them said that he/she tried to ease the tension of the bullied and the bully, and make peace between them. Another teacher reflected that after being informed of the bullying case, he/she tried to keep the bully busy either by erasing the board or by distributing class work paper; and the teacher tried on the other hand to raise the self-esteem of bullied through encouragement and allowing the bullied to feel safe and not alone. However, another teacher responded that in bullying cases, the students could solve their problems alone but if he/she had to interfere, the teacher provided small moral lesson for students; and informed the administration in cases of physical bullying.

The teachers' questionnaire reflected that $100 \%$ of the respondents teachers believed that the school cared for the safety of the students from bullies. However, more than three quarter of the teachers reflected on how they felt such caring such as one third of the teachers believed that through urgent meeting with the administration to discuss the students' cases, and through 
classes' deliberations at the end of school year through which the troublemakers were excluded from the school. In addition, less than one fifth of the teachers believed that the school care was felt trough oral and written warnings that were provided for the bullies. However, other respondents provided different comments on the school care either from the administration supports to teachers, or from the school's rules, as well as from the overall school environment and based on the teachers' comments during teachers' meetings.

As for the modifications needed on discipline policies, less than three quarter of the teachers believed that hallways, playground, and bathrooms were the school areas that needed more surveillance to control students' bullying. However, less than one fifth of the teachers believed that only playground was in need for more surveillance. One teacher chose bathrooms whereas another teacher chose hallways, playground, bathrooms and classrooms as the school areas that needed more surveillance. On safety procedures that should be used to control students' discipline problems, half of the teachers chose adult hall monitors whereas more than one tenth of them chose cameras while more than one tenth of the teachers chose adult hall monitor and cameras. However, more than one fifth of the teachers believed that none of the safety procedures were needed. Additional data reflected that more than half of the teachers believed that the school's discipline policies were in need of some minor change whereas more than one tenth of the teachers believed that the discipline policies were in need of a major overhaul change. However, more than one third of the teachers believed that the discipline policies were sufficient and appropriate and need no change. Further data also reflected that the majority of the teachers believed that no need for any additional discipline rule whereas more than one tenth of the teachers believed that some additional rules were needed such as a program of punishment on Saturday's and detention rule. 
Data from the teachers' questionnaire (Appendix N) that checked the teachers' perceptions concerning the modifications needed on discipline policies showed that the teachers were not convinced that a particular discipline rule needed modification. Each teacher provided his/her opinion concerning the rule that needed to be formalized (Appendix $\mathrm{O}$ ).

\section{Summary of data from students' questionnaire.}

As a summary of the data received on the communication of the school's discipline policies, the majority of the students responded that they and their parents had received the school's discipline policies booklet. The majority believed that the school communicated its discipline policies through written forms such as newsletters, handbooks, and through parents' meetings. The majority of the students believed that their teachers reminded them of the school's discipline policies after the summer vacation whereas half of the students believed that they had received training on the school's discipline policies while less than half of the students believed that no training has taken place.

In the summary of the data received from the set of questions on the students' perceptions on the school's discipline policies; the majority of the students responded that they understand all their school's rules and they thought that their school had too many rules. Half of the students' sample responded that they were not involved in the development of their classroom rules whereas less than half of the students' sample believed that they were involved in such development. In addition, more than half of the students' sample believed that the rules were fairly enforced in the school while less than half of the students' sample believed the opposite way. Further analysis of data revealed that the majority of the students believed that their 
teachers were too strict in the enforcement of the school's discipline rules contrary to a small minority.

Additional data received from the set of questions on the students' behavioral record in the students' questionnaire reflected that less than quarter of the total students' sample received oral warnings; the majority of these students received a single oral warning; most of them were on misbehaving during learning time. As the level of warnings increased, the number of students receiving such warnings decreased. Most of the oral warnings were between the Seventh graders whereas the major written warnings were between the Ninth graders. The majority of the warnings were on disrupting others through laughing and talking in class, not doing homework, forgetting school's materials. Some of these warnings were on uniform violation, and bullying others physically and verbally while the minorities of these warnings were on cheating, using cell-phone, using bad language, eating in class, tardiness, and smoking. None of the warnings were on absenteeism, hair and jewelry, emotional bullying, chewing gum, and vandalizing school's properties.

In making a comparison between the previous data with the data received from the review of school's documents concerning the students' behavioral record, most of the students' sample had provided the data on the warnings of the previous school year and not the data of the current school year. Therefore, for validity and reliability purposes, the data of the school's documents concerning the students' behavioral record will only be taken into consideration.

As a summary of the data received from the set of questions that checked the problems in the enforcement of the school's discipline policies, less than half the students' sample were ignorant of some of their discipline rules, since they did something and afterward they were surprised it 
was against the school's discipline rules. Also, there were problems in the enforcement of these rules, since the majority of the students sometimes got away with breaking discipline rules; in addition of having more than one tenth of the students' sample get away most of the time with breaking these rules. Also, the majority of the students' sample believed that they were being blamed when it was not their fault which reflects that there were problems in following up the provoker of discipline violation before blaming the students.

On the set of questions that checked the school's bullying problems, the majority of the students' sample believed that their school was a safe place; small minority contacts nobody in case of being bullied whereas the majority revealed that they contact others in such cases. Further data received from the set of questions that checked the modifications needed in the school's discipline policies reflected that more than half of the students' sample believed that the playground was the most school area that needed surveillance; then, bathrooms; then, hallways. Only small minority were against putting more surveillance in any of the school's area. In addition, less than half of the students' sample believed that any of the rules needs changing whereas more than half of them believed that some changes were a must such as the uniform rule, the hair code, the jewelry code, the cell-phone code, talking rule, make-up and polish rule, absenteeism code, the honor list and the bad behavior code, the leisure time rule, and the classroom rule concerning going to bathroom, chewing gum, drinking water in class, and not carrying a lot of books. On the other hand, the majority of the students believed there is no need for additional rule while small minorities believed that some rules should be added such as increasing leisure time, providing canteen's rule, adding new classroom rules, and stealing rule. In addition of having flexible uniform rule and flexible school philosophy concerning eating in class, providing air conditioning in classes, and hiring a school counselor. 
The previous sections presented chapter four that includes the results of the research. The following chapter presents the findings of the research. 


\section{Findings}

The chapter presents the common findings from the following instruments: the alignment between the manifest and latent analyses of written codes with the evaluation of enforcement of teachers and administrator based on observation (see Appendix Q). Additional comparison between written codes and the data from the personnel's discipline records provided more findings. Further comparison was made between data from observation and that of both questionnaires. Another comparison was made between personnel discipline records, data of observation, and data of both questionnaires. A final comparison was made between the discipline analysis, the data from the observation, and the data of both questionnaires. Findings are used to address the research questions: How were written discipline policies enforced at school? And what were the perceptions of the Intermediate teachers and students of the effectiveness of such enforcement?

\section{Findings Related to First Research Question}

Based on the first research question of "how were written discipline policies enforced at school?" the findings emerged from doing many comparisons such as the comparison between manifest, latent analysis and enforcement of teachers and administrators. Another comparison was made between discipline written codes and personnel's discipline records. A further comparison was also made between discipline analysis, observation and questionnaires. Additional comparison was made between personnel discipline records, observation and questionnaires. 
Comparison between Manifest, Latent Analysis and Enforcement.

In the comparison between the manifest and latent analysis of the school's discipline policies, there was an alignment between both analyses on the research variables of wearing jewelry, disrupting others, forgetting books or materials, carrying cell-phone, chewing gum, and eating in class. However, in the comparison between written codes and enforcement, there was an alignment between the codes of wearing jewelry and its enforcement by the administration while the codes of disrupting others, forgetting books or materials, carrying cell-phone, chewing gum, and eating in class had discrepancy between written codes and the enforcement by the teachers and administration except that there was similar enforcement by the teachers and administration on carrying cell-phone (see Table Q1).

On the other hand, there was an alignment between one kind of analysis and the enforcement by teachers and administration on the variables of smoking, absenteeism, homework, physical bullying, and tardiness except that smoking had the alignment with latent analysis and enforcement while the others had the alignment with manifest analysis only (see Table Q1).

Moreover, there was an alignment between one kind of analysis and one type of enforcement either that of teachers or that of administration on the variables of cheating, hair style, uniform, and verbal bullying. However, there was an alignment between latent analysis and the enforcement of the administration on the variables of hair style and uniform while cheating variable had an alignment with latent analysis and teachers' enforcement; yet verbal bullying had alignment between manifest analysis and administrative enforcement (see Table Q1). 
Furthermore, there were discrepancies between the written codes and the enforcement by the teachers and administration in addition of discrepancy between the latent and manifest analysis on the research variables of using bad language, vandalism, and emotional bullying despite that there was an alignment between the enforcement of teachers and administration on vandalism code (see Table Q1).

\section{Comparison between Written Codes and Personnel's Discipline Records.}

The comparison between the data received from the written codes and the review of personnel's discipline records reflected the following discrepancies: There was unfair enforcement by the administration on the rules of doing homework and disrupting others which affected effective enforcement (DeJung \& Duckworth, 1984) since the majority of the students who had different number of referrals received one to three referrals; except that one male student received six referrals for not doing homework; yet, no oral warning was provided for the student and neither a letter was sent to his parents (see Table E8) which reflected a discrepancy between the discipline policies and the personnel's discipline enforcement. As for the discrepancy on the enforcement of the rule that prevents disrupting others, the school's personnel provided immediately major written warnings on disrupting others for three male Intermediate students (see Table E6) without following the order of cumulative referrals and warning (see Table E8 ) which was also against the school's discipline policies. This reflected an authoritarian philosophy of the school (Metz, 1978). These discrepancies may indicate two findings either the school's personnel provided severe warnings on the violation of disrupting others without following the sequence of warnings that were presented in the discipline policies or the school's 
personnel followed the discipline policies in the violation of disrupting others but the cumulative referrals, and warnings were not recorded in the discipline records during the research.

\section{Comparison between Discipline Analysis, Observation and Questionnaires.}

Based on the comparison between the data received from the discipline analysis, observation and questionnaires of students and teachers, the following findings emerged: Based on the discipline analysis, some rules had unclear consequences such as code of students' hair, chewing gum, eating in class, wearing jewelry, and disrupting others which could lead to misconception from the students and their parents. In addition that $27 \%$ of the respondent students revealed that they understood some of the rules. In addition, the majority of the students' violations were on disruption and wearing jewelry which reflected that the students were not knowledgeable about the consequences of violation on these rules (see Appendix K).

Another finding was that other rules were poorly justified such as providing same consequences on non moral conventional violation and intentional moral violation without discriminating between them such as providing the minor oral warning for the violation of not doing homework and for littering (see Appendices O \& K) which could lead to perceive school's policies as unfair and irrational (Goodman, 2006).

Another finding was that the discipline codes provided easy conditions for eliminating the warnings from the students discipline records (see Table E9) which weakened the warnings and led to decrease in the school's morals (Bear, 1998) since the students could violate again the discipline rules after the elimination of each warning (see Table E9). This information was also 
approved during the informal interview with the academic supervisor that these conditions provided more problems than they solved.

Another finding was that there was discrepancy between the documents of discipline policies that were delivered to parents and students since the students were provided with extra sheet that lists the rules' infractions for which oral, minor, and written warnings were provided which led to discrepancy between the latent and manifest analysis of each document (see Appendix F). This reflected that the parents didn't have clear ideas about the infractions that led to warnings which could affect the school's atmosphere being conducive to learning in case of student's discipline violation (Meyers, Kenneth \& Pawlas, 1989).

\section{Comparison between Personnel Discipline Records, Observation and Questionnaires.}

Based on the comparison between the data received from the review of personnel's discipline records, observation, and questionnaires, the following findings emerged: Some Intermediate teachers were not supporting the school's procedures for establishing the discipline rules (see Appendices M \& S) since their philosophy was not in harmony with that of the school (Duckworth \& Kenneth, 1984). Therefore, the enforcement of the discipline codes was inconsistent between the teachers, which resulted in that the school philosophy became erratic despite that in written codes the school had an authoritarian philosophy (Metz, 1978).

Another finding was that the teachers whose philosophy was in harmony with that of the school were involved in providing the troublemakers with different kinds of warnings (see Appendix M) which reflected that students were subject to immediate consequences (Adams, 2000). 
Further findings emerged that the students who were relatives to school's members or had members of authority power in the school tend to misbehave knowing that they could get away with the consequences of their actions (DeJung, 1984). In addition, the majority of their teachers tended to report less frequently the violations of these students which reflected unfair enforcement by the teachers (see Appendices K \& O).

Additional findings reflected that the teachers who had problems of classroom management tend to report less frequently on the students' discipline infractions since they believed that they could be blamed more than students which (see Appendix K). Based on observation the administrator was cooperative with the teachers in discussing students' discipline problems by calling for urgent meetings and class deliberations (Meckel, 1980). However, some teacher believed that not all problems were discussed at proper time.

Further finding based on observation (Table 40) and discipline analysis was that the school needed minor change in its discipline policies; and many teachers believed that adult hall monitor were needed Others believed that stronger punishments were required. This was also reflected in the supervisors' answers (Appendix O) that In-School suspension was needed (Gottfredson \& others, 1989).

\section{Findings Related to the Second Research Question}

Based on the second research question of "what were the perceptions of the Intermediate teachers and students of the effectiveness of discipline enforcement?" the findings emerged from doing other comparisons such as the comparison between data of teachers' and students' questionnaires and data of observation. 


\section{Comparison between Questionnaires and Observation.}

The comparison between the data received from observation and the data received from teachers and students' questionnaires reflected the following findings:

The administrator aimed for orderly and nonopressive environment through achieving many steps such as: good enforcement of the rule of absenteeism and tardiness as a way to decrease teaching disruption and increase learning time (DeJung \& Duckworth, 1985) (see Table Q1). In addition, many teachers believed that they were strict in enforcing the rule of absenteeism and tardiness. This was also reflected in the supervisors' responses (see Appendix S). Also, less class cuts interruptions were made in comparison with those of the previous year since none of the teachers disrupted their peers during the observation session (DeJung, 1984). The class interruptions were made by the supervisor during the morning while checking the students' absenteeism. This was also approved by the respondent teachers whereas others believed that the number of the class cuts were still the same as previous years. Another finding was that the school used the suspension and exclusion approach as a way to decrease discipline problems (Adams, 2000). As a result, less discipline problems occurred during the current year in comparison with that of the previous year since the administration excluded five troublemakers at the end of the previous year (see Appendices M \& S). Moreover, the school followed the division of small campuses according to the students' levels as a step to manage and control the students' discipline (Gottfredson, 1989; Duke, 1989). However, the shortage in human resources to monitor the students during recess especially near the canteen resulted in not reporting students' discipline violations. Bathrooms, hallways and playground also needed more surveillance (see Appendix M) and the playground was the major area that needed supervision 
(see Appendix K). Another finding was that internal communication on school's discipline policies was through announcement in corridors, stairs and on the playground bulletin board. In addition the school provided discipline handouts to students and parents at the beginning of the school year (Gaustad, 1992; Duke, 1989; Meyers, Kenneth \& Pawlas, 1989) (see Appendices K \& M). The teachers were also provided with an up-to-date discipline copies (DeJung, 1984). Findings also show that the administration insisted on having authentic evidence from parents that they received the copies of the school's discipline policies (Meyers, et al. 1989). And the teachers reminded the students of the discipline policies after the summer vacations and throughout the school year based on the students' behavior (Meyers, et al. 1989). One teacher acted as a guidance counselor during recess in one of the classes which provided the opportunity to solve some students' problems and act on their behavior (Goodman, 2006). This reflected that some of the Intermediate students contact their preferable teacher to discuss their problems on continuous basis.

However, neither training on the discipline rules and procedures were done in the school for students nor follow up procedures were done by the teachers to check the level of understanding of the rules and reveal misconceptions of discipline codes which contradicted the recommendations of Black and Down (1992). This resulted that some students were surprised that some of their actions were against discipline policies. In addition, neither the students nor the teachers were involved in the development of the school's discipline rules unlike recommendations of Cameron (2006). Furthermore, the teachers were just involved in the initiation and implementation of the discipline policies by being involved in the deliberation sessions at the end of school year to take the decisions on excluding the troublemakers. Some teachers believed that the implementation of the deliberation sessions was most effectively 
implemented in the school; others believed that they preferred to be more involved in the decisions concerning the students' discipline policies.

The majority of students and teachers perceived their school as having too many rules which contradicted the recommendation of Duke (1989) to have fewer formal school's rules as a way to achieve order. In addition, many students got away from the consequences of discipline infractions especially on disruption, vandalism, wearing jewelry, hair style, and all kinds of bullying due to the lack of reporting by the teachers in classes and by the supervisor in the playground which was also approved by the teachers' responses (see Appendices O \& S).

The students' misbehavior that caused the most stress for the Intermediate teachers (DeJung \& Duckworth, 1984) was laughing for no reason and talkativeness others considered students' disruption during explanation and hyperactivity as stressful.

The majority of the teachers didn't know how to deal with the bullies and the bullied which (Appendix M) which reflected that campaign and workshops against bullying were needed for the school's practitioners (Cameron, 2006).

Thus the study shows that no alignment was found between the written codes and the enforcement by the administrators and teachers except for the rules of smoking, absenteeism, tardiness, homework, and physical bullying. However, there was an alignment between a type of codes analysis and the enforcement of either the teachers or the administration for the rules of hair code, uniform, jewelry, verbal bullying, and cheating. In addition, the male Intermediate students tended to violate rules more than females except for the policy against eating in class. The teachers slightly enforced discipline codes whereas administrators moderately enforced 
them. Moreover, many students got away with breaking rules due to shortage of human resources to monitor students during recess while in classes the teachers tend to report less frequently due to the following reasons: if they had management problems; their philosophy was not in harmony with that of the school; if the students had relatives of power positions in the school. In addition, many teachers didn't know how to treat with bullying cases. However, some of the teachers had misconceptions concerning their responsibilities in the enforcement of discipline rules and that of staff. Therefore, unfair enforcement resulted in altering the school's philosophy from authoritarian to erratic.

Other factors that led to high frequencies of students' discipline violations were that some rules had unclear consequences of violations while others were poorly justified and no discrimination was made between non-moral conventional and intentional moral violations. In addition, the written codes provided easy conditions for eliminating the warning from the students' discipline record which caused more problems than they solved such as: the students tend to violate the rules after the elimination of the warning.

Furthermore, the study shows that the administrator tried to create an orderly nonopressive environment by providing good enforcement of the rules of absenteeism and tardiness; less class interruptions; used suspension and exclusion approach with severe discipline violations; used division of campuses; communicated its discipline policies with students, parents, teachers. In addition, the teachers reminded students of discipline rules after summer vacation. And a teacher played the role of a guidance counselor during recess to solve students' problems. Furthermore, the teachers were involved in the initiation and implementation of discipline policies; yet, neither the teachers nor the students were involved in development of school's discipline rules. As well 
as, neither training nor follow up procedures were ever done to check the level of the students' understanding of discipline codes.

As for the perceptions of students concerning the enforcement of the discipline rules, the study shows that some students' perceived that strict and unfair discipline enforcement was applied by teachers and the school needed no modification in discipline policies whereas others believed that teachers were lenient and some changes were needed in written codes since many students got away with breaking rules. On the other hand, the majorities of the teachers believed that inconsistent enforcement of discipline rules were applied by the teachers and the school was in need of minor changes in codes such as more punishment on discipline violations and InSchool Suspension were needed. However, the majorities of teachers and students believed that additional monitoring was needed in playground, hallways and bathrooms.

The previous chapter presented the findings of the research whereas the following chapter presents the conclusion. 


\section{Conclusion}

The chapter presents the conclusion, the implication, the recommendations, and the limitations of the current research.

As a conclusion, the male Intermediate students tended to violate the discipline policies more than females except that the female tended to violate the rule on eating in classroom more than the male students. However, they tend to have same frequency of violations on forgetting materials and chewing gum. In addition, the Intermediate students mostly committed disruptions; they highly committed jewelry and vandalism violations; they quite committed physical bullying, not doing homework and verbal bullying; they moderately committed emotional bullying and hair style violations; they slightly committed tardiness, forgetting books, absenteeism, uniform violations, using bad language and eating in class. They committed negligible violations of chewing gum and cheating; and they didn't commit any cell-phone violations and smoking. However, the teachers highly enforced the rules on tardiness, forgetting books, absenteeism, cheating, cell-phone, and smoking; they quite enforced the rules of not eating in classroom and doing homework; they moderately enforced the rule that prevent chewing gum; they slightly enforced the rule of disrupting others, vandalism, hair style, and physical bullying. Nevertheless, they didn't enforce the rules on uniform, jewelry, bad language, verbal and emotional bullying. In addition, the teachers tend to report less on the students whose parents or relatives had power positions in the school and when the teachers had problems of classroom management. On the other hand, the administration highly enforced the rules of tardiness, absenteeism, disrupting others, eating in classroom, chewing gum, carrying cell-phone and smoking; yet, it quite enforced the rules of doing homework, forgetting school materials, and cheating. Moreover, the 
administration moderately enforced rules on uniform and slightly enforced the rules on jewelry, physical bullying, verbal bullying, and vandalism. However, the administration was lenient in the enforcement of the rules of hair style; yet, no reaction was seen on emotional bullying and using bad language. In addition, the punishment on cheating, vandalism, verbal bullying, and disruption were not in harmony with the written codes. Therefore, the administration moderately enforced the discipline violations.

On the other hand, there was alignment between latent and manifest analysis of written codes and the administrative enforcement on the rule on jewelry. Other alignment was found on one kind of the analysis with the enforcement of teachers and administration of the rules of smoking, absenteeism, homework, physical bullying, and tardiness. Another alignment was found on one type of analysis with the enforcement of teacher or administration of the rules of cheating, hair style, uniform, and verbal bullying. Some other rules had an alignment between the latent and manifest analysis; yet, no alignment was found with the enforcement such as the rules of disruption, chewing gum, cell-phone, eating in class, and forgetting books. However, no alignment was found between the analysis of written codes and their enforcement of the rules of using bad language, vandalism, and emotional bullying.

Furthermore, few discrepancies were found between written codes and personnel's discipline records such as unfair enforcement on rule of doing homework and disruption by not providing warnings for cumulative referrals of not doing homework whereas providing immediate warnings for disruption without following the sequence of cumulative referrals.

On the other hand, the school administrator tried to create an orderly nonopressive environment by taking many steps as follows: good enforcement of absenteeism and tardiness 
rules, used suspension and exclusion approach, and division of campuses, communicated its discipline policies with students, parents and teachers, and assured that parents received policies copies. Also, the teachers reminded the students of the rules after the summer vacation; and a teacher played the role of a guidance counselor during recess. However, no training on discipline policies and no follow up procedures were done to check the level of students' understanding of the codes and to reveal misconception on these rules. Neither the teachers nor the students were involved in the development of the school's discipline codes; yet the teachers were involved in the initiation and the implementation of the discipline policies. In addition, the school was perceived by the students as having too many rules and the enforcement of the discipline policies was unfair since many students got away with violating the discipline policies. This was due to many factors such as the lack of human resources to monitor the students during the recess; some teachers had problems of classroom management, and they tend not to report on the students' discipline infractions due to the fear of being blamed instead of students. Other teachers tend not to report on the students with powerful relatives in the school. Some others had a philosophy that was not in harmony with that of the school since they were not supporting the discipline procedures for managing students' discipline which resulted in inconsistent enforcement of discipline policies, and altered the school from authoritarian to erratic philosophy. In addition, many teachers didn't know how to deal with the bully and the bullied.

Some other factors led to high frequency of students' violations such as some of the school's discipline rules had unclear consequences whereas others were poorly justified and no discrimination was made between non-moral conventional and intentional moral violations. Furthermore, the school provided easy conditions for eliminating the warning from the students' 
discipline record which caused more problems than it solved; and the students could advantages violate the rules after the elimination of the warning.

As for the perceptions of the students concerning the enforcement of the discipline policies, the majority of the students revealed that the teachers were strict in the enforcement of the discipline rules; yet, some teachers revealed that they were lenient in such enforcement. In addition, there was discrepancy between the teachers' responses concerning the responsibilities of the staff in the enforcement of the discipline rules which reflected that some of the teachers had misconceptions concerning their responsibilities in the enforcement of rules and that of the staff. In addition, half of the teachers believed that the school faced minor discipline problems and needed to add In-school detention and to have higher punishment on some discipline violations. Last, the teachers and the students believed that additional monitoring is needed in playground, hallways, and bathrooms as well as adult hall monitor to have better control of students' discipline infractions.

\section{Implications}

The potential application or implications of my study were that school discipline policies reflect one facet of school's "climate or atmosphere" or the quality of the human interactions within the school whether these interactions were positive or negative, healthy or poisonous between the students, teachers, and administration. Therefore, by enforcing clear and understandable policies that were developed with the collaboration of the teachers and staff, students' behavior could be controlled, and more conducive environment to learning could be achieved (DeJung \& Duckworth, 1985). 


\section{Recommendations}

As recommendations, it is preferable for the school under study to develop a detention rule after the school dismissal and on Saturdays to prevent the students from committing successive violations of the discipline rules. In addition, the classroom rules should be presented clearly on the bulletin board in each classroom; and the students need to be involved in the development of these rules as a motivation to abide by these rules. Additional supervision is needed in the playground near the canteen, and behind the barriers that surrounded the basketball court. This could be achieved with the help of a staff member that will assist in monitoring during the recess; and it is preferable to supervise the students from the first floor which provides wider view for monitoring; and the discipline violations could be observed and recorded. Also, abigger canteen is preferable to provide equal opportunity for the students to buy their snacks and food. Therefore, additional discipline rules should be added such as canteen rule that prevents the students from pushing each other and that obliges the students to stand in line in a civilized way to buy their food.

As for the written discipline codes, it is preferable to clarify and specify the consequences of the violations and the successive violations of the discipline rules related to tardiness, students' hair, jewelry, uniform, cheating, smoking, vandalism, littering and cell-phone. Also, it is preferable to state the consequence of the discipline violation in a clear statement and avoid ambiguity and vague sentences such as "the students are under their own culpabilities in case of violation". It is also preferable to state consequences of discipline violations that are attainable and realistic instead of providing tough punishment that are not applied on the ground such as stating that the students are subject to suspension in case of smoking and cheating in addition to taking zero on the cheated exam. Therefore, it is preferable to state attainable consequences 
which reflect the seriousness of the administration in the enforcement of these rules such as to state that the school has the right to dismiss or suspend the student who cheated depending on the situation; and the same concept goes for smoking. As for the rule that prevents vandalism, it is preferable to clarify the kinds of vandalism. Therefore, it is preferable for the students to be trained on classroom activities that are related to the themes of vandalism, littering, bullying, and disrupting others to clarify these themes and to relate them to the discipline rules. As for the cellphone code, it is preferable to clarify the consequence of carrying and using the cell-phone on school premises in written form and not as norms in order to be referred to whenever it is needed in case of violation. As for the uniform rule, it is preferable to clarify that the female students commit uniform violation in case they alter the form of their uniform to tight pants and the rule has to specify the consequence of wearing tight pants such as the female students will not join their classes until they buy another uniform pants. It is also preferable to state the consequence of violating the hair code in case of putting gel by the male students. However, in case of being lenient in the enforcement of hair code to be with the modern trends of hair style, it is preferable to remove such code and replace it with a code that clarifies that weird hair cut and style are not allowed and state the consequence of violations.

The school in fact used letter grades for student's behavior. Therefore, it is also preferable to motivate students to achieve high behavioral grades by stating in the written discipline codes the consequence for each behavioral grade under the grade B such as the student is put on probation in case of $\mathrm{B}^{-}$whereas the student takes a minor written warning for grade $\mathrm{C}+$. However, the student gets a major written warning for having $\mathrm{C}$ on the behavioral grade while a commitment from parent is signed as authentic evidence in case the student received a behavioral grade of $\mathrm{C}^{-}$. Nevertheless, the student is subject to suspension in case his/her behavioral grade is D in 
addition of being deprived from the recess and from fieldtrips. Furthermore, it is preferable to state the consequences of achieving a behavioral grade of A and B+ such as to specify part of the bulletin board in each classroom for a list of behavior that present the names of the students that have the highest scores of $\mathrm{A}$ and $\mathrm{B}+$; and divide the responsibilities and duties of classroom management between these students who are named as leaders. Each two leader students of the same grade behavior share one responsibility or a duty for only one month, and then they are changed by their advisor teacher. These responsibilities and duties could be the assembly line leaders, the class cleanliness, the desk arrangement and cleanliness, bringing or sending the classroom agenda, arranging the bulletin boards, erasing the board, bringing chalk and other materials. It is also preferable that the advisor teacher be responsible for hanging on the bulletin board the behavioral list that presents the names of the leader students, their corresponding responsibilities or duties, and their duration in that position in a table form. In this way, the students are motivated to achieve an advanced behavioral grade to have a leader title, and in a way they learn how to be effective members in their school environment which will help them be efficient members in the society.

It is also preferable to deliver to students and parents the list that presents the routine discipline violations and the consequences of oral warnings, minor written warnings, and major written warnings since it presents the actions that the students may think it is acceptable while it is consider a discipline violation that could lead to warnings. It is also preferable to remove the section of warning disposition from the list of routine discipline violations that presented the way warnings were eliminated from the students' discipline records since they were not applicable on the ground. It is also preferable to provide workshops and campaign against bullying for practitioners to clarify the ways of dealing with the bully and the bullied. 
As for future recommendations for expected research, it is preferable to conduct additional research on the enforcement of the discipline policies at the Intermediate and Secondary students in more than one school and on different territories of Lebanon as a way to achieve generalization. It is also recommended that the expected research be conducted in three intervals during the school year such as the beginning, the middle, and the end of the school year which will clarify whether the students' discipline violations increase or decrease based on the enforcement of the discipline policies.

\section{Research Limitations}

Choosing the schools for the current research was one of the major difficulties that I faced as a researcher; many nearby schools refused to provide me access to their settings due to the privacy of their schools' and students' documents: Probing into the school's discipline policies needed the approval of the board of trustees. However, there were some conditions such as explaining the purposes of the research during the interviews with the school administrator and supervisor, and providing a written form of the research purpose as well as copies of the teachers' and students' questionnaires to be reviewed by the School's Committee before providing the final acceptance. Such difficulties caused the lack of randomization in selecting the school and resulted in conducting the current research only in one school. Therefore, generalization could not be achieved which is considered a major limitation in the current research. However, in case study design, the aim is to present data and findings so that others in the same field may benefit from the insight that the study provided. Another limitation was to conduct the research without any assistant which limited recording the students' violations of discipline policies in all the Intermediate classes at the same time. Therefore, the discrepancy 
between the frequency of the observed violations and the frequency of the teachers' reactions to violations was due to the limitation of not observing all Intermediate classes at the same time in order to record all the students' violations and their teachers' reactions. As a result, when the frequency of teachers' reactions on students' violations was more than the students' observed violations, the percentage of teachers' reactions was considered $100 \%$ which reflects that the teachers were highly enforcing the observed discipline rule. A further limitation was the inability to review the personnel's discipline documents of the previous year to compare the frequencies of the students' violations of the school's discipline policies with that of the current year in order to determine whether such frequencies were increasing or decreasing. The previous school's documents were exterminated at the end of each school year; as a result, the related information was only collected from the teachers' questionnaire. A final limitation was the lack of up-to-date studies on similar topics of the current research which led me to base the study on earlier research. 


\section{References}

Adams, A.T. (2000). The status of school discipline and violence. Annals of the American Academy of Political and Social Science, 567, 140-156.

Association of Secondary Teachers of Ireland, ASTI. (2004). Guidelines for reviewing of school discipline policy. ASTI Information Leaflet. Ireland.

Ayers, C. \& Shavel, D. (1997). Adventure programming \& prevention of adolescent problem behaviors: Applying Research and the Public Health Model of Prevention. Annual AEE International Conference Proceeding (ERIC Document Reproduction Services No. ED 414 125)

Barrett, R. K. (1993). Urban adolescent homicidal violence: An emerging public health concern. Urban League Review, 16(2), 67-75

Bear, G. (1998). School discipline in the United States: Prevention, correction and long-term social development. School Psychology Review, 27(1), 14-32.

Black, D., \& Downs, J. C. (1992). Administrative intervention: A discipline handbook for effective school administrators. Longmont, Colorado: Sopris West, Inc.

Brookover, W. (1979). School social systems and student achievement: Schools can make a difference. New York: Praeger.

Brown, B. V. (1993). Family functioning and adolescent behavior problems: An analysis of national survey of families and households. Washington, DC: Child Trends, Inc.

Bryman, A. (2001). Social research methods. Oxford: Oxford University Press.

Buckley, P. K. (1977). An ethnographic study of an elementary school teacher's establishment and maintenance of group norms. Unpublished doctoral dissertation. Houston, Texas: University of Houston. 
Burns, R. B. (2000). Introduction to research methods $\left(4^{\text {th }}\right.$ edition) London: Sage.

Cameron, M. (2006). Managing school discipline and implications for school social workers: A review of the literature. National Association of Social Workers, 2(8), 242-243

Charney, R. (1991). Teaching children to care: Management in the responsive classroom. Greenfield: MA, Northeast Foundation for Children.

Cohen, L., Manion, L. \& Morrison, K. (2000). Research methods in education (5 $5^{\text {th }}$ edition) London: Routledge Falmer.

DeJung, J. \& Duckworth, K. (1985). An examination of student discipline policy in three middle schools. Final Report. Eugene, Oregon: Center for Educational Policy and Management. (ERIC Document Reproduction Services No. ED 256018 )

Duckworth, K. (1984). School discipline policy: A problem of balance. Eugene, Oregon: Center for Educational Policy and Management.

Duke, D. L. (1989). School organization, leadership, and student behavior. In strategies to reduce student misbehavior. In O. Moles (Ed.) Strategies to reduce student misbehavior. (pp. 187). Washington, D.C.: Office of Educational Research and Improvement, U.S. Department of Education, 1989. (ERIC Document Reproduction Services ED311 608)

Duke, D. \& Meckel, A. (1980). Student attendance problems and school organization. Urban Education (15), 325-357.

Edmonds, R. (1979). Effective schools for the urban poor. Educational Leadership (37), 15-27.

Evertson, C., Sanford, J. \& Emmer, E. (1981). "Effects of class heterogeneity in junior high school." American Educational Research Journal (18), 219-232.

Fraenkel, J. R. \& Wallen, N.E. (2008). How to design and evaluate research in education. New York: McGraw Hill Companies, Inc. 
Gaustad, J. (1992). School discipline. Eugene, Oregon. (ERIC Document Reproduction Services No. ED 99-C0-0011)

Goodman, J. F. (2006). School discipline in moral disarray. Journal of Moral Education, 35(2), 213-230

Goodman, J. F. \& Lesnick, H. (2001). The moral stake in education: Contested premises and practices. Boston: MA, Longman.

Goodman, J. F. \& Lesnick, H. (2004). Moral education: A teacher centered approach. Boston: MA, Pearson.

Gottfredson, D. G. (1989). Developing effective organizations to reduce school disorder. In O. Moles (Ed.) Strategies to reduce student misbehavior (pp. 87-104). Washington, D.C.:

Office of Educational Research and Improvement, U.S. Department of Education. (ERIC Document Reproduction Services No. ED 311 608)

Gottfredson, D. C., Gottredson, G.D., \& Hybl, L. (1993). Managing adolescent behavior: A multiyear, multi-school study. American Educational Research Journal, 30 (1), 179-215.

Griffith, J. (2003). School as organizational models: Implications for examining school effectiveness. The Elementary School Journal, 104 (1), 29-47.

Hawkins, D.F. (1996). Ethnicity, race, class, and adolescent violence. University of Colorado at Boulder: Center for the Study and Prevention of Violence.

Katz, D., \& Kahn, R. L. (1978). The social psychology of organizations. New York: Wiley.

Kohn, A. (1996). Beyond discipline: From compliance to community. Alexandria: VA, Association for Supervision and Curriculum Development. 
LaPoint, V., Alleyne, S. I., Mitchell, H. W., \& Lee, J. (2003). Attitude of youth of color on Student dress and uniforms: A case of commercialism in schools. Journal of Negro Education, 72, (4), 406-417.

Likert, R. (1967). The human organization. New York: McGraw-Hill.

Lipsitz, J. (1982). Successful schools for young adolescents: A report on a report. Paper presented at the annual meeting of AERA.

Mason, C. A. (1996). Neither too sweet nor too sour: Problem peers, maternal control, and problem behavior in African American adolescents. Child Development, 67(5), 2115-30.

Meseinger, J. F. (1984, October). Megatrends relating to adolescent violence and correctional education. Paper presented at the National Adolescent Conference on Behavior Disorders, Pensacola, FL.

Metz, M. H. (1978). Classrooms and corridors. Berkeley, Cal.: University of California Press. Meyers, C., Kenneth, G. \& Pawlas, G. (1989). The principal and discipline. Elementary Principal Series No. 5. Bloomington, Indiana: Phi Delta Kappa Educational Foundation. (ERIC Document Reproduction Services No. ED 315 915)

Moles, O. C. (1989). Strategies to reduce student misbehavior. Washington, D.C.: Office of Educational Research and Improvement, U.S. Department of Education. (ERIC Document Reproduction Services No. ED 311608 )

Noddings, N. (2002). Starting at home: Caring and social policy. Berkeley: CA, University of California Press.

Nucci, L. P. (1989). Challenging conventional wisdom about morality: The domain approach to values education In, L.P. Nucci (Ed.) Moral development and character education (pp.183203). Berkeley, CA, McCutchan 
Nucci, L. P. (2001). Education in the moral domain. New York: Cambridge University Press.

Preuesse, K. (2004). Guidance and discipline strategies for young children: Time out is out. In K. M. Paciorek \& J. H. Munro (Eds) Early childhood education 04/05: Twenty fifth edition (pp.129-131). Dubuque: IA, McGraw-Hill/Dushkin,

Public Agenda (2004). Teaching interrupted: Do discipline policies in today's public schools faster the common good? New York: Public Agenda.

Rutter, M. (1983). Family and school influences on behavioral development. Journal of Child Psychology and Psychiatry and Allied Discipline, 26, 349-368

Rutter, M., Maughan, B., Mortimore, P., \& Ouston, J. (1979). Fifteen thousand hours. Cambrige, Mass.: Harvard University Press.

Seydlitz, R. \& Jenkins, P. (1998). The influence of family, friends, and community on delinquent behavior. In T.P. Gullota, G. R. Adams \& R. Montemayor (Eds.), Delinquent violent youth: Theory and interventions (pp. 53-97). Thousand Oaks, CA: Sage Publications.

Sheldon, S. B. \& Epstein, J. Y. (2002). Improving student behavior and school discipline with family and community involvement. Education and Urban Society, 35, 4-26

Silbereisen, R. K. (1990). Family income loss and economic hardship: Antecedents of adolescents' problem behavior. New Directions for Child Development, 46, 27-47.

Tashakori, A. (1998). Mixed methodology: Mixing qualitative and quantitative research. London: Sage

Travers, M. (2001). Qualitative research through case studies. London: Sage

Turiel, E. (2002). The culture of morality: Social development, context, and conflict. New York: Cambridge University Press 
Walker, H. M. (1993). Anti-social behavior in school. Journal of Emotional and Behavioral Problems, 2(1), 20-24.

Watson, M. \& Ecken, L. (2003). Learning to trust: Transforming difficult elementary classrooms through development discipline. San Francisco: CA, Jossey-Bass

William, J. (1983). A re-analysis of the 1981-82 [district] suspension report. Mimeographed. California State University, Fresno. 


\section{Appendices}

Appendix A: Intermediate Teachers' Questionnaire on School Discipline Policy

Appendix B: Intermediate Students' Questionnaire on School Discipline Policy

Appendix C: Observational Checklist and Total Data Collected

Appendix D: Buckley's Model on Classroom Rules Establishment and Enforcement

Appendix E: Table Presenting Data Received From Reviewing Personnel Discipline Records

Appendix F: Table of Codes and Categories for the Research Variables

Appendix G: Table of Latent Analysis for the Research Variables

Appendix H: Table Verifying Triangulation of Similar Concepts in the Different Instruments

Appendix I: Table Verifying Triangulation of Alternative Concepts in Teachers' Questionnaire

Appendix J: Table Presenting the Summary of Data Received from the Student's Questionnaires

Appendix K: Table Presenting the Data from the Students' Questionnaires

Appendix L: Table Presenting the Summary of Data Received from the Teachers' Questionnaires

Appendix M: Table Presenting the Data of the First Part from the Teachers' Questionnaires

Appendix N: Table Presenting the Data of the Second Part from the Teachers' Questionnaire

Appendix O: Table Presenting the Percentages of Data from Teachers' Questionnaire ( ${ }^{\text {nd }}$ Part)

Appendix P: Tables Presenting Observation Data 
Appendix Q: Table Presenting Alignment between Written Codes and Discipline Enforcement Appendix R: Table of Triangulation of Concepts between Questionnaire and Observation Appendix S: Table Presenting Data from Supervisor Responses on Questionnaire 


\section{Appendix A}

\section{Intermediate Teachers ' Questionnaire on School Discipline Policy}

For each sentence below, circle the underlined word(s) which you believe best describe your school. For questions with lines after, write out your answer on those lines. If you need more space use the back of this page.

Example: Compared to other Lebanese private school, I believe teacher morale is
A)

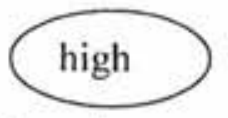
B) average
C) low in our school.

I. I have been provided with the school discipline policy booklet.
A) No
B) Yes.

If yes, when?

A) At the beginning of the year

B) In the middle of the year.

C) At the end of the year.

2. The school communicates its policies and rules through
A) school's newsletters
D) students' meetings
G) not applicable.

B) handbook to students

C) handbook to parents

E) parents' meeting

F) others

3. Do you remind your students of school's discipline rules from time to time? A) Yes B) No.
If yes, A) after the winter vacations
B) after the summer vacations
C) after both vacations
D) not applicable
E) others

4. I would A) always B) generally C) rarely consider revision of my classroom rules depending on the students' behavior.

5. Do you train your students on the schools' rules? A) Yes B) No. If yes, when? And for how many days?

6. Do you think that the students understand all the school's discipline rules? A) Yes

B) No. If no, why? 
7. In my opinion, our school's philosophy regarding student discipline is A) fully B) partially C) minimally approved by our teaching staff.

8. Our school's procedures for establishing student disciplinary rules are A) fully B) partially C) minimally supported by our teaching staff.

9. Do you think that your school has too many rules?
A) №
B) Yes.

10. Were you involved in developing the school discipline policy?
A) Yes
B) No

11. If yes, state which one(s)?

I2. I would prefer to have A) more $\quad$ B) less $\quad$ C) no change in teacher participation in deciding student discipline policies in our school.
13. In making my classroom rules, I
A) generally
B) sometimes
C) seldom
D) never involve students.

14. It is A) very B) moderately C) not especially important for students to learn to make their own decisions about obeying rules.

15. Are you satisfied with the manner in which the school discipline policy is implemented?

16. A) Yes B) №? If No, state why?

17. What aspect of the school policy do you consider is most effectively implemented?

18. What aspect of the school policy is least effectively implemented?

19. What type of students' indiscipline (disruptive behavior) causes the most stress for you?

20. Our teachers are A) undivided

B) nearly undivided

C) split in their agreement with their administrator's management concerning students' discipline. 
21. Discipline problems A) have decreased

B) have increased

C) are about the same as in the last couple years.

22. There seems to be A) more B) less C) the same number of class delay in program as in previous years.

23. There seems to be A) more B) less C) the same number of class cuts as in previous years.

24. Students' discipline is A) a major B) a minor C) not a problem in our school.

25. Our school's discipline policies are

A) sufficient and appropriate and need no change

B) in need of some minor change

C) in need of a major overhaul change.

$\begin{array}{lll}\text { 26. Managing student discipline in my classes take about } & \text { A) less than } 10 \% & \text { B) } \underline{10 \%}\end{array}$

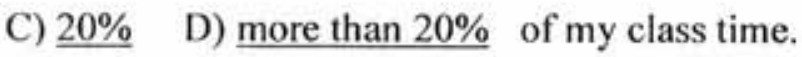

27. Have you been involved in providing any intermediate student with an oral warning $\begin{array}{ll}\text { (تنبيه شفوي) ? A) No } & \text { B) Yes. If yes, how many times from the beginning of the school }\end{array}$ year? -.-What were the main reasons?

28. Have you been involved in providing any intermediate student with a minor written warning $\begin{array}{lll}\text { (تنييه خطني) A) No } & \text { B) Yes. If yes, how many times from the beginning of the school }\end{array}$ year? - What were the main reasons?

29. Have you been involved in providing any intermediate student with a major written warning $\begin{array}{lll}\text { (انذار خطي) ? A) No } & \text { B) Yes. If yes, how many times from the beginning of the school }\end{array}$ year? - What were the main reasons?

30. Do you have bullies (people who hurt others emotionally, verbally, or physically) in your $\begin{array}{lll}\text { classes? } & \text { A) } \underline{\text { No }} & \text { B) } \underline{\text { Yes }}\end{array}$ 
31. Do students contact you in case of being bullied (suffering from the bully)? A) № B) Yes. If yes, how do you treat the bully and the bullied? Please, express yourself in one paragraph on the back of the page in any language you choose (Arabic, French, or English).

32. Does the school care for the safety of its students from the bullies?

A) No

B) Yes

33. How do you know this?

34. Where do you think there should be more surveillance to control students' bullying? In the
A) hallways
B) playground
C) bathrooms
D) all of the three areas
E) other areas such as

35. Which safety procedure(s) should be used by the school?
A) Adult hall monitors
B) police guard
C) Metal detectors
D) Cameras
E) None

36. Is there any rule your school should have which it doesn't have now?

37. I have been at this school for
A) one
B) two
C) three to five
D) $\underline{\text { six to ten }}$

E) more than ten years.

38. I have been a school teacher for
A) one to two
B) three to five
C) $\operatorname{six}$ to ten

D) more than ten years. 


\section{Appendix A (Continued)}

Below are thirteen school rules (A-M) regarding students' behavior for which the students are subject to disciplinary action, and a list of possible teacher comments or beliefs (1-10) about these rules. To the right of each "comment" are columns referring to each of the rules. In the Table referring to the school's rules and teachers' comments, check $(\sqrt{ })$ as many of the cells you need to, to describe your feelings or beliefs about each comment.

Rule A: Being absent from class without a valid reason.

Rule B: Being late to class more than once.

Rule C: Not doing homework.

Rule D: Repeatedly disrupting classroom instruction.

Rule E: Not abiding by the dress code (hair, jewelry, or uniform).

Rule F: Bullying other children physically (hitting, pushing, tripping, or spitting);

bullying others emotionally (spreading rumors to cause hurt; teasing by an individual or group), or bullying others orally (verbal intimidation for fun, or insult to name, family, race, gender, belief, dress, or appearance).

Rule G: Using bad language with peers or teachers.

Rule H: Using cell-phone on school premises.

Rule 1: Chewing Gum.

Rule J: Eating during learning time (in class, library, or laboratory).

Rule K: Smoking on school premises.

Rule L: Cheating on the exam.

Rule M: Vandalizing school's properties. 


\begin{tabular}{|c|c|c|c|c|c|c|c|c|c|c|c|c|c|c|c|c|c|}
\hline \multirow{3}{*}{$\begin{array}{l}\text { School's } \\
\text { Rules }\end{array}$} & \multirow[b]{3}{*}{ 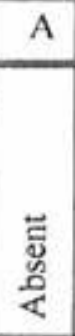 } & \multirow[b]{3}{*}{ 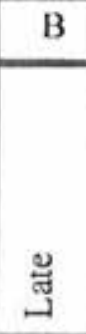 } & \multirow{3}{*}{ 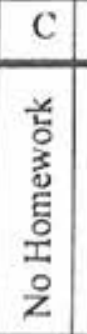 } & \multirow{3}{*}{ 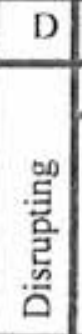 } & \multirow{2}{*}{\multicolumn{3}{|c|}{\begin{tabular}{|c|} 
E \\
Dress Code \\
\end{tabular}}} & \multirow{2}{*}{\multicolumn{3}{|c|}{$\frac{F}{\text { Bullying }}$}} & \multirow{3}{*}{ 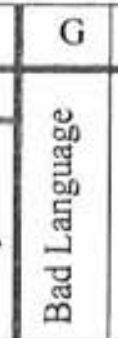 } & \multirow{3}{*}{ 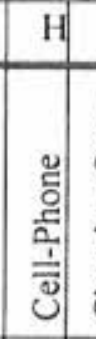 } & \multirow{3}{*}{ 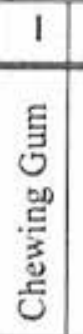 } & \multirow{3}{*}{ 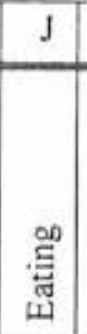 } & \multirow{3}{*}{ 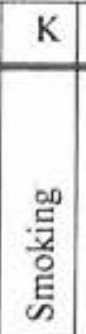 } & \multirow{3}{*}{ 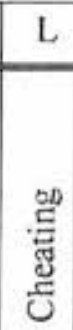 } & \multirow{3}{*}{ 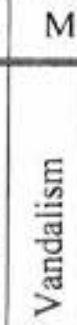 } \\
\hline & & & & & & & & & & & & & & & & & \\
\hline & & & & & 点 & 空 & 壳 & 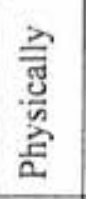 & 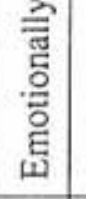 & 촗 & & & & & & & \\
\hline \multicolumn{18}{|l|}{$\begin{array}{l}\text { 1. The rule violates } \\
\text { students' rights. }\end{array}$} \\
\hline \multicolumn{18}{|l|}{$\begin{array}{l}\text { 2. It is the total staff } \\
\text { business to enforce } \\
\text { it. }\end{array}$} \\
\hline \multicolumn{18}{|l|}{$\begin{array}{l}\text { 3. This rule causes } \\
\text { more problem than it } \\
\text { solves. }\end{array}$} \\
\hline \multicolumn{18}{|l|}{$\begin{array}{l}\text { 4. This rule is } \\
\text { unnecessary }\end{array}$} \\
\hline \multicolumn{18}{|l|}{$\begin{array}{l}\text { 5. Some students get } \\
\text { away with breaking } \\
\text { this rule more than } \\
\text { others. }\end{array}$} \\
\hline \multicolumn{18}{|l|}{$\begin{array}{l}\text { 6. The penalties for } \\
\text { breaking this rule } \\
\text { are too light. }\end{array}$} \\
\hline \multicolumn{18}{|l|}{$\begin{array}{l}\text { 7. I am lenient in } \\
\text { enforcing this rule. }\end{array}$} \\
\hline \multicolumn{18}{|l|}{$\begin{array}{l}\text { 8. This rule affects } \\
\text { very few students } \\
\text { and need to be }\end{array}$} \\
\hline \multicolumn{18}{|l|}{ formalized. } \\
\hline \multicolumn{18}{|l|}{$\begin{array}{l}\text { 9. I participated in } \\
\text { developing this rule. }\end{array}$} \\
\hline $\begin{array}{l}10.1 \text { am very strict } \\
\text { in enforcing this } \\
\text { rule. }\end{array}$ & & & & & & & & & & & & & & & & & \\
\hline
\end{tabular}

Please feel free to add any additional comments or clarifications on the back of this page which you feel would help me to understand the student discipline practices in your school. I thank you for your cooperation. 


\section{Appendix B}

Intermediate Students' Questionnaire on School Discipline Policy (Sample 's age: 12-15 years)

Your school was picked to participate in a study about school's discipline rules and to check the procedures followed of enforcing (implementing) these rules. I have asked your teachers and now it is your turn. I would like you to tell me how YOU FEEL about school rules.

You do not have to answer these questions if you don't want, but if you do, I ask you to be as honest as you can. Your answers will help me learn how rules are working in your school. Since this paper does not have your name on it, and it is sent directly to me in a sealed envelope, no one at your school will be able to see or read what you have written. On most questions, circle one of the underlined words as your answer.

EXAMPLE: I try to be on time for all my classes. A)

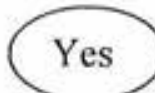

B) No

For questions with lines after, write out your answer on those lines. If you need more space use the back of this page.

When you have finished, fold your paper, place it in the big envelope that is with your classroom teacher. Thank you in advance for your cooperation.

1. I have received the school's rules and regulations booklet which lists the students' rights and responsibilities. A) $\underline{\text { No }} \quad$ B) $\underline{\text { Yes }}$

2. My parents have received a similar copy of the school's rules at the time of my enrollment.
A) №
B) Yes

3. The school communicates its policies and rules through

A) school's newsletters

B) handbooks

C) students' meetings

D) parents' meeting

E) others-

-F) not applicable.

4. The teacher reminds us of the school rules

A) after the winter vacations

B) after the summer vacations

C) after both vacations

D) no

5. I have received A) one day of

B) two days of

C) one week of

D) two weeks of

E) no training on the school rules.
6. I clearly understand
A) all
B) some
C) none of my school rules.

7. I think my school has too many rules.
A) №
B) $\underline{\text { es }}$ 
8. Have you been involved in the development of your classroom rules

A) No B) Yes.

9. I believe that rules are fairly enforced (implemented) in my school.

A) №

B) Yes

10. Most of my teachers are too strict about disciplinary rules.

A) №

B) Yes

11. Did you ever do something, and afterwards you were surprised to learn it was against school rules?
A) No
B) Yes

12. How often do you get away with breaking rules?
A) Never
B) Sometimes
C) Most of the time

13. How often are you blamed for breaking rules when it was not your fault?
A) Never
B) Occasionally
C) Sometimes

14. Have you received an oral warning (تنبيه شُفوي) A) № B) Yes. If yes, how many times this school year? What was the main reason?

15. Have you ever received a minor written warning (تنبيه خطىى)? A) № B) Yes. If yes, how many times since the beginning of the school year? What was the main reason?

16. Have you ever received a major written warning (انذار خطي) ? A) № B) Yes. If yes, how many times since the beginning of the school year? What was the main reason?

17. I feel that my school is a safe place
A) №
B) Yes

18. If you are bullied (being afraid of someone who hurts you physically, verbally, or emotionally), whom do you contact?
A) Your friend
B) Your parents
C) Your teacher
D) The school's counselor or advisor
E) The school's supervisor
F) Nobody
G) others

19. As a step to control students' bullying ( hurting others physically, verbally, or emotionally), my school needs more surveillance (observation, inspection, or supervision) in the
A) hallways
B) playground
C) bathrooms
D) others-

20. Which school rule needs changing?

21 . Is there any rule your school should have which it doesn't have now? 
Appendix $C$

\section{Observational Checklist: Total Data Collected}

Date:

Place:

Time:

Grade level:

Duration:

Teacher:

Material:

\begin{tabular}{|c|c|c|c|c|c|}
\hline $\begin{array}{l}\text { Incidence of } \\
\text { violation } \\
\text { \& total Percentage }\end{array}$ & $\begin{array}{l}\text { Total \# of } \\
\text { Frequency }\end{array}$ & $\#$ occurred & $\begin{array}{l}\% \text { of incidence } \\
\text { out of the total } \\
\text { Violations }\end{array}$ & $\begin{array}{l}\text { Type of punishment } \\
\text { used }\end{array}$ & Comments \\
\hline $\begin{array}{l}\text { Being Absent } \\
(12.5 \%)\end{array}$ & 14 & $9 \delta \& 5$ 우 & & $\begin{array}{l}\text { Supervisor insisted } \\
\text { that parents call } \\
\text { school to present } \\
\text { valid reason }\end{array}$ & $\begin{array}{l}13 \text { with valid } \\
\text { reason } \\
1 \delta^{3} \text { with no valid } \\
\text { reason }\end{array}$ \\
\hline Being Late $(9 \%)$ & 10 & $6 \delta^{\pi} \& 4$ 오 & & & \\
\hline \multicolumn{6}{|l|}{$\begin{array}{l}\text { Homework } \\
\text { Violations }\end{array}$} \\
\hline \multicolumn{6}{|l|}{ Class Disruption } \\
\hline \multicolumn{6}{|l|}{$\begin{array}{l}\text { Violating Dress } \\
\text { Code }\end{array}$} \\
\hline \multicolumn{6}{|l|}{$\begin{array}{l}\text { Inappropriate } \\
\text { Hair } \\
\text { Cut/Style/Color }\end{array}$} \\
\hline \multicolumn{6}{|l|}{ Wearing Jewelry } \\
\hline $\begin{array}{l}\text { Emotional } \\
\text { Bullying }(1.6 \%)\end{array}$ & 2 & $2 \hat{3}$ & $1.6 \%$ ठ & $\begin{array}{l}\text { Not seen \& not } \\
\text { reported }\end{array}$ & \\
\hline Verbal Bullying & 41 & $41 \hat{\sigma}$ & $32 \% 3$ & $\begin{array}{l}\text { Bully was taken } \\
\text { away from recess. }\end{array}$ & $\begin{array}{l}\text { One incidence of } \\
\text { verbal bullying was } \\
\text { reported to }\end{array}$ \\
\hline & & & & bully & supervisor \\
\hline $\begin{array}{l}\text { Physical Bullying } \\
(66 \%)\end{array}$ & 85 & $\begin{array}{l}700^{\circ} \\
15 \%\end{array}$ & $\begin{array}{l}54 \% \text { के } \\
12 \% \text { के }\end{array}$ & $\begin{array}{l}\text { Not seen by the } \\
\text { supervisor: } \\
\text { No consequences }\end{array}$ & $\begin{array}{l}\text { Pushing near } \\
\text { canteen: } \\
60 \vec{\delta} \& 15 \text { ㅇ } \\
\text { Throwing water: } \\
2 \overrightarrow{8} \\
\text { Slapping and } \\
\text { kicking behind } \\
\text { walls: } 8 \hat{\delta}\end{array}$ \\
\hline Total Bullying & 128 & $\begin{array}{l}113 \sigma \\
15 \%\end{array}$ & $\begin{array}{l}88 \% \text { o } \\
12 \% \text { 우 }\end{array}$ & & \\
\hline \multicolumn{6}{|l|}{$\begin{array}{l}\text { Using Bad } \\
\text { Language }\end{array}$} \\
\hline Using Cell-Phone & & & & & \\
\hline
\end{tabular}




\begin{tabular}{|c|c|c|c|c|c|}
\hline Chewing Gum & & & & & \\
\hline \multicolumn{6}{|l|}{$\begin{array}{l}\text { Eating In } \\
\text { Class/Library/Lab }\end{array}$} \\
\hline \multicolumn{6}{|l|}{ Smoking } \\
\hline \multicolumn{6}{|l|}{ Cheating } \\
\hline $\begin{array}{l}\text { Vandalizing } \\
\text { School Properties }\end{array}$ & 113 & & & & \\
\hline $\begin{array}{l}\text { Tearing out trees' } \\
\text { leaves }(30 \%)\end{array}$ & 34 & $30 \overbrace{}^{7} \& 4 \%$ & $26 \% \delta \& \& \% \%$ & $\begin{array}{l}\text { No consequences on } \\
\text { discipline records }\end{array}$ & $\begin{array}{l}\text { Supervisor } \\
\text { reprimanded the } \\
\text { bigger student only }\end{array}$ \\
\hline $\begin{array}{l}\text { Shacking roughly } \\
\text { the garden weir } \\
(13 \%)\end{array}$ & 15 & $15 \delta^{8}$ & $13 \% \xi^{3}$ & $\begin{array}{l}\text { Not seen by } \\
\text { supervisor }\end{array}$ & \\
\hline $\begin{array}{l}\text { Damaging the } \\
\text { garden weir }(1 \%)\end{array}$ & 1 & 18 & $1 \%$ क & $\begin{array}{l}\text { Forbidding all } \\
\text { Intermediate students } \\
\text { from entering the } \\
\text { small garden }\end{array}$ & \\
\hline $\begin{array}{l}\text { Standing on chairs } \\
(2 \%)\end{array}$ & 2 & 23 & $2 \% 3$ & $\begin{array}{l}\text { Not seen in the } 1^{\text {st }} \\
\text { floor }\end{array}$ & \\
\hline Littering (54\%) & 61 & $\begin{array}{l}46 \delta \& \\
159 \\
\end{array}$ & $41 \% \delta \& 13 \%$ & No consequences & \\
\hline $\begin{array}{l}\text { Total Vandalism } \\
\text { Violations }\end{array}$ & 113 & $\begin{array}{l}94 \delta \& 19 \\
\text { \& }\end{array}$ & 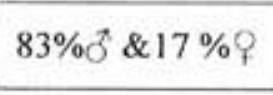 & & \\
\hline
\end{tabular}

Symbols Used: $\quad \delta:$ Male $\quad$ i: Female

Percentage: Violations/ Number of Students' Sample $=$ Violations $/ 112$

Bullying or vandalism Percentages:

Violations of Specific rule/Total Frequencies total violations of the same kind 


\section{Appendix C Continuity}

Types of Punishment Used for Breaking the School discipline Policy

\begin{tabular}{|c|c|c|c|c|c|c|c|c|c|c|c|}
\hline $\begin{array}{l}\text { Types of Punishment } \\
\text { used }\end{array}$ & 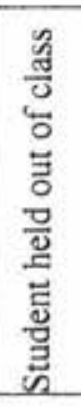 & 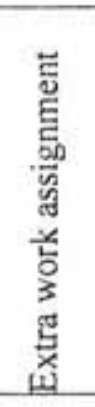 & 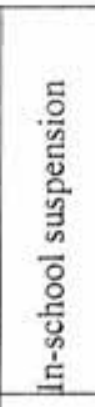 & 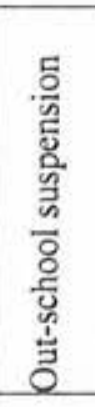 & 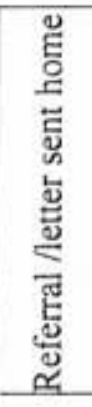 & 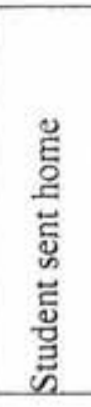 & 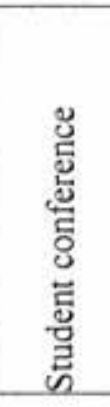 & 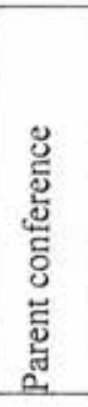 & 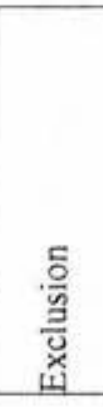 & 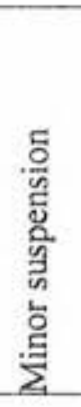 & 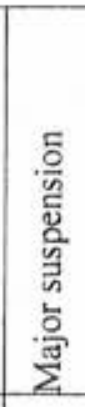 \\
\hline $\begin{array}{l}\text { Being absent without valid } \\
\text { reason }\end{array}$ & $\checkmark$ & & & & $\checkmark$ & & & & & & \\
\hline Being late (Tardy) & $\sqrt{ }$ & & & & $\sqrt{ }$ & & & & & & \\
\hline Homework violations & & $\sqrt{ }$ & $\sqrt{ }$ & & $\sqrt{ }$ & & & $\checkmark$ & & & \\
\hline Class disruption & & $\sqrt{ }$ & $\sqrt{ }$ & & & & & & & & \\
\hline Violating dress code & $\sqrt{ }$ & & & & $\sqrt{ }$ & $\sqrt{ }$ & & & & & \\
\hline $\begin{array}{l}\text { Inappropriate hair } \\
\text { cut/style/color }\end{array}$ & $\sqrt{ }$ & & & & $\sqrt{ }$ & & & & $\sqrt{ }$ & & \\
\hline wearing jewelry & & & & & & & & & & & \\
\hline $\begin{array}{l}\text { Bullying others } \\
\text { emotionally }\end{array}$ & & & & & & & $\sqrt{ }$ & & & & \\
\hline Bullying others verbally & & & $\sqrt{2}$ & & & & $\sqrt{ }$ & & & & \\
\hline Bullying others physically & & & & & & & & & $\sqrt{ }$ & & \\
\hline Using bad language & & & & & $\sqrt{ }$ & & & $\sqrt{ }$ & $\sqrt{ }$ & & \\
\hline Using cell-phone & & & & & & & & & & & \\
\hline Chewing Gum & $\sqrt{ }$ & & & & & & & & & & \\
\hline $\begin{array}{l}\text { Eating in } \\
\text { Class/Library/Lab }\end{array}$ & $\sqrt{ }$ & & & & & & & & & & \\
\hline Smoking & & & & $\sqrt{ }$ & $\sqrt{ }$ & & & & & & \\
\hline Cheating & & & & & $\sqrt{ }$ & & & & & & $\sqrt{ }$ \\
\hline Vandalizing properties & & & $\sqrt{ }$ & $\sqrt{ }$ & & & & & & & \\
\hline
\end{tabular}




\section{Appendix D}

The Classroom Rules' Establishment and Enforcement Model by Buckley (1977)

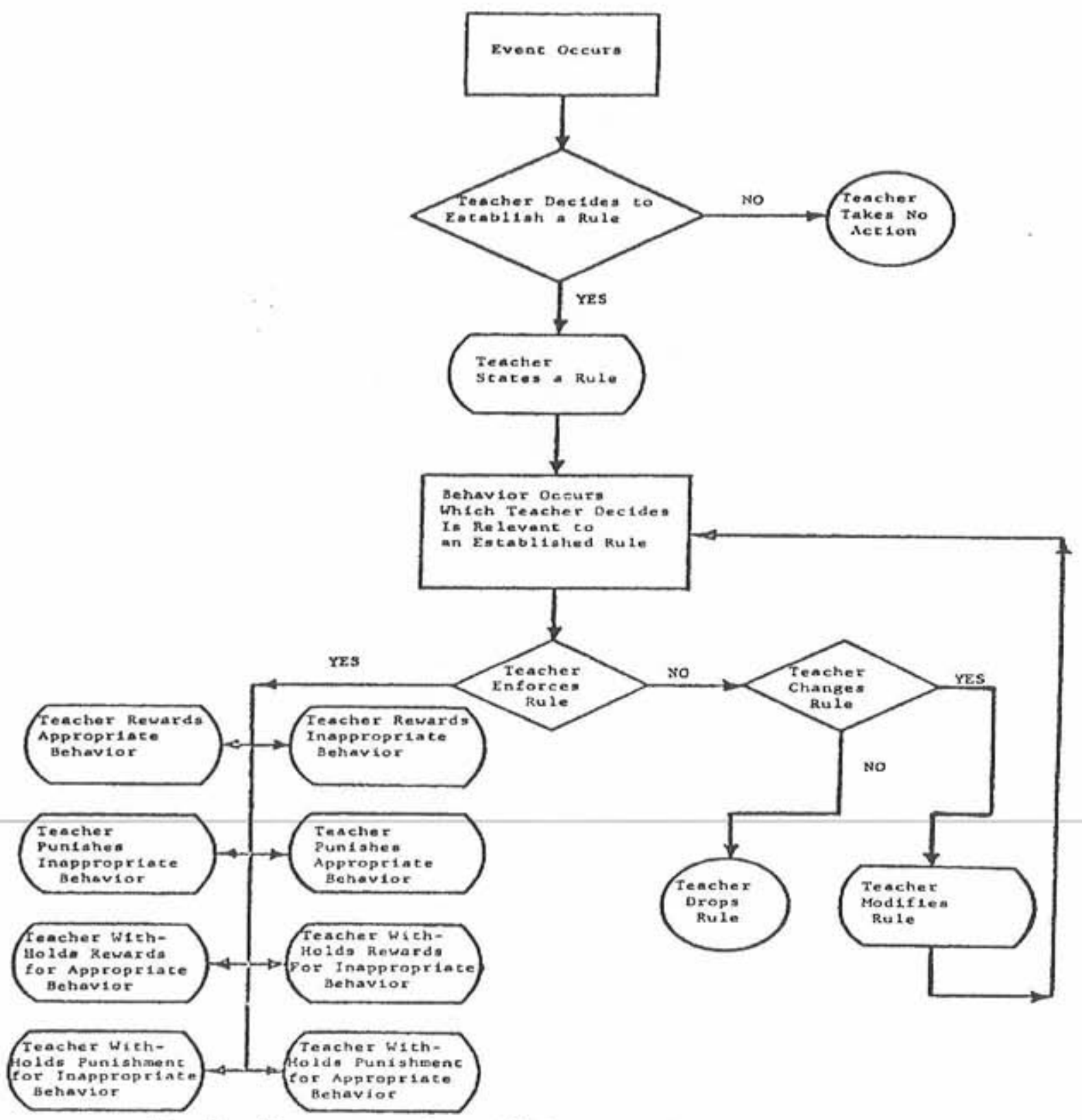

Fic. 1-Classroom rule establishment and enforcement model 


\section{Observational checklist}

Date:

Time:

Duration:

Place:

Grade level:

Material:

Teacher:

The Classroom Rule's Enforcement Table:

\begin{tabular}{|c|c|c|c|c|c|c|c|c|c|c|c|c|c|c|c|c|c|}
\hline \multirow[b]{3}{*}{$\begin{array}{l}\text { Teacher } \\
\text { Enforces the } \\
\text { rule }\end{array}$} & \multirow[b]{3}{*}{$\begin{array}{l}\text { 莺 } \\
\text { م⿱ 口) }\end{array}$} & \multirow{3}{*}{ 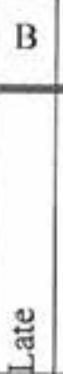 } & \multirow{3}{*}{ 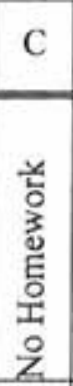 } & \multirow{3}{*}{ 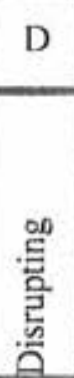 } & \multicolumn{3}{|c|}{$\mathrm{E}$} & \multicolumn{3}{|c|}{$\mathrm{F}$} & G & $\mathrm{H}$ & 1 & $\mathrm{~J}$ & $\mathrm{~K}$ & L & $\mathrm{M}$ \\
\hline & & & & & Dre & ss C & ode & & allyir & & \multirow[b]{2}{*}{ 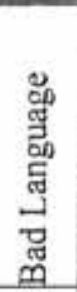 } & \multirow[b]{2}{*}{ 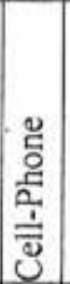 } & \multirow[b]{2}{*}{ 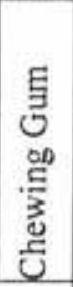 } & \multirow[b]{2}{*}{ 军 } & \multirow[b]{2}{*}{ 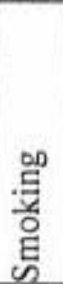 } & \multirow[b]{2}{*}{ 莺 } & \multirow[b]{2}{*}{ 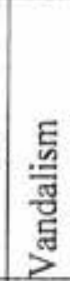 } \\
\hline & & & & & & 空 & $\begin{array}{l}E \\
\text { E } \\
\text { E }\end{array}$ & 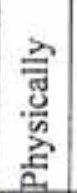 & 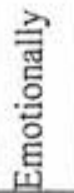 & 空 & & & & & & & \\
\hline $\begin{array}{l}\text { 1. Rewards appropriat } \\
\text { behavior. }\end{array}$ & & & & & & & & & & & & & & & & & \\
\hline $\begin{array}{l}\text { 2. Punishes inappropri } \\
\text { behavior. }\end{array}$ & & & & & & & & & & & & & & & & & \\
\hline $\begin{array}{l}\text { 3. Withholds reward } f \\
\text { appropriate behavior. }\end{array}$ & & & & & & & & & & & & & & & & & \\
\hline $\begin{array}{l}\text { 4. Withholds punishm } \\
\text { inappropriate behavio }\end{array}$ & & & & & & & & & & & & & & & & & \\
\hline $\begin{array}{l}\text { 5. Rewards inappropri } \\
\text { behavior. }\end{array}$ & & & & & & & & & & & & & & & & & \\
\hline $\begin{array}{l}\text { 6. Punishes appropria } \\
\text { behavior. }\end{array}$ & & & & & & & & & & & & & & & & & \\
\hline $\begin{array}{l}\text { 7. Withholds reward } \\
\text { inappropriate behavio }\end{array}$ & & & & & & & & & & & & & & & & & \\
\hline $\begin{array}{l}\text { 8. Withholds punishn } \\
\text { appropriate behavior. }\end{array}$ & & & & & & & & & & & & & & & & & \\
\hline 9. Changes the rule. & & & & & & & & & & & & & & & & & \\
\hline 10. Drops the rule. & & & & & & & & & & & & & & & & & \\
\hline 11. Modifies the rule. & & & & & & & & & & & & & & & & & \\
\hline 12. Takes No action. & & & & & & & & & & & & & & & & & \\
\hline
\end{tabular}




\section{Appendix E}

Table Presenting Data Received From Reviewing School's Personnel Discipline Records

\begin{tabular}{l}
\begin{tabular}{l} 
Table E1. \\
Number of Students Receiving Referrals \\
\hline
\end{tabular}$\quad$ Number \\
\hline $\begin{array}{l}\text { Number of } \\
\text { students receiving } \\
\text { referrals. }\end{array}$
\end{tabular}

\section{Table E2.}

Number of Discipline Referrals Reported by Teachers

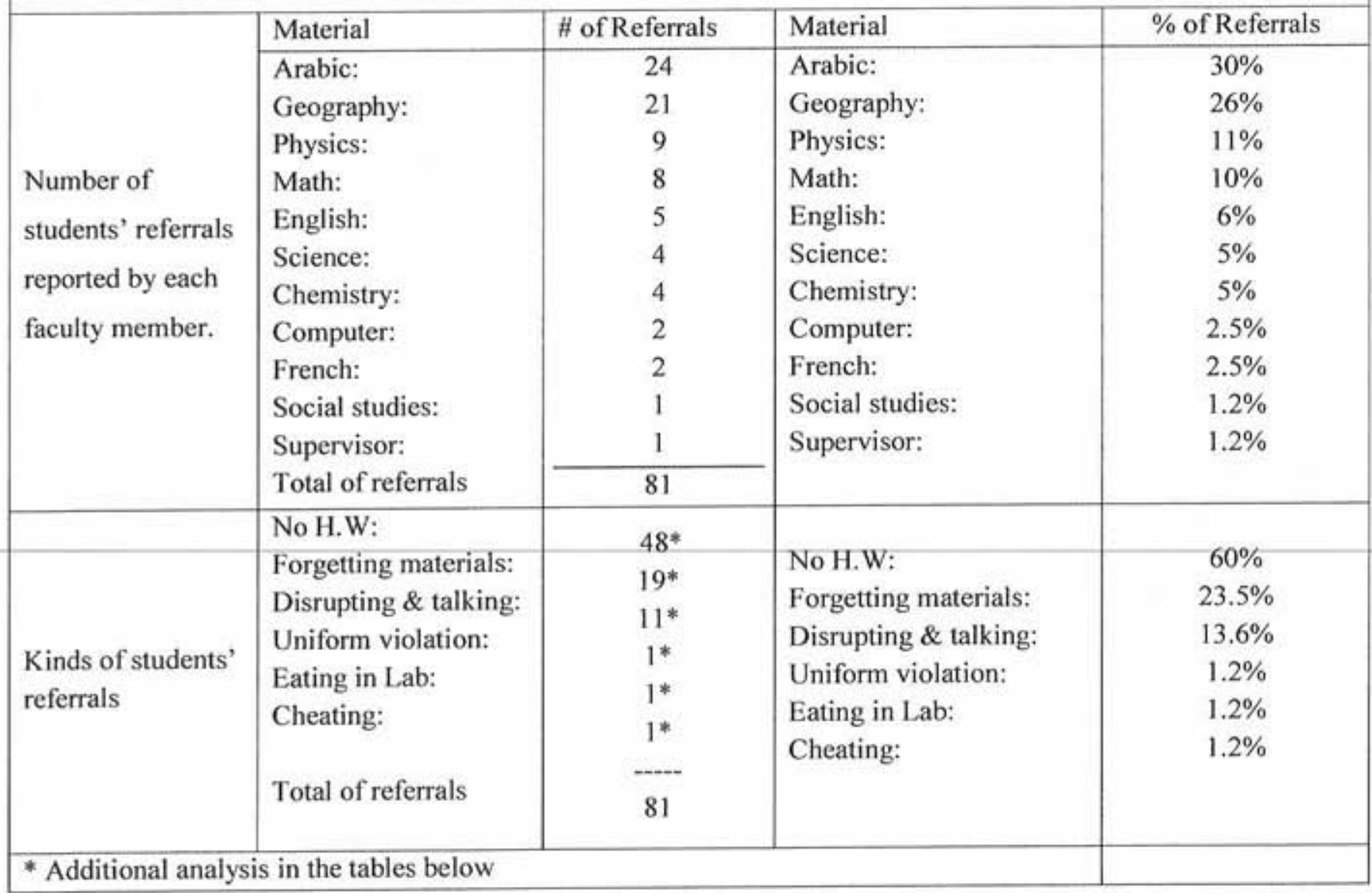




\begin{tabular}{|c|c|c|c|c|c|c|c|c|}
\hline \multicolumn{9}{|c|}{$\begin{array}{l}\text { Table E5. } \\
\text { Number of Referrals According to Grades \&Sections }\end{array}$} \\
\hline \multirow{4}{*}{$\begin{array}{l}\text { Distribution of } \\
\text { referrals } \\
\text { according to } \\
\text { Intermediate } \\
\text { grades }\end{array}$} & \multicolumn{2}{|c|}{ Number of referrals } & \multirow{2}{*}{$\begin{array}{l}\text { A } \\
32\end{array}$} & \multirow{2}{*}{$\begin{array}{l}\text { B } \\
17\end{array}$} & \multicolumn{2}{|c|}{ Percentage of referrals } & \multicolumn{2}{|c|}{$\begin{array}{l}\text { A } \\
\text { B }\end{array}$} \\
\hline & Seventh grade & 49 referrals & & & Seventh grade & $60.5 \%$ & $21 \%$ & 39.5 \\
\hline & Eighth grade & 22 referrals & 14 & 8 & Eighth grade & $27.1 \%$ & $17.1 \%$ & $10 \%$ \\
\hline & Ninth grade & 10 referrals & 2 & 8 & Ninth grade & $12.5 \%$ & $2.5 \%$ & $10 \%$ \\
\hline \multirow{4}{*}{$\begin{array}{l}\text { Distribution of } \\
\text { warnings } \\
\text { according to } \\
\text { Intermediate } \\
\text { grades }\end{array}$} & Grade & \# of Warning & A & B & \multicolumn{2}{|c|}{ Percentage of Warning } & A & B \\
\hline & Seventh grade & $\begin{array}{c}1 \text { Warning } \\
\text { (1 male, } 0 \\
\text { female) }\end{array}$ & 0 & 1 & Seventh grade & $25 \%$ & $0 \%$ & $25 \%$ \\
\hline & Eighth grade & No warning & 0 & 0 & Eighth grade & $0 \%$ & $0 \%$ & $0 \%$ \\
\hline & Ninth grade & $\begin{array}{l}\text { 3warnings } \\
(3 \text { male, } 0 \text { female })\end{array}$ & 0 & 4 & Ninth grade & $75 \%$ & $0 \%$ & $75 \%$ \\
\hline
\end{tabular}

\section{Table E6.}

Frequency of Rule Infractions Resulting in Taking Warning

\begin{tabular}{|c|c|c|c|c|}
\hline \multirow{4}{*}{$\begin{array}{l}\text { Kind of warning } \\
\text { given to } \\
\text { cumulative } \\
\text { referrals } \\
\text { reflected the } \\
\text { frequency of } \\
\text { administrative } \\
\text { responses to } \\
\text { rules' } \\
\text { infractions }\end{array}$} & $\begin{array}{l}\text { Seventh } \\
\text { grade }\end{array}$ & $\begin{array}{l}* 1 \text { Oral warning } \\
(1 \text { male })\end{array}$ & $\begin{array}{l}25 \% \text { of warning for } \\
\text { cheating }\end{array}$ & Effective enforcement \\
\hline & \multirow{3}{*}{$\begin{array}{l}\text { Ninth } \\
\text { grade }\end{array}$} & $\begin{array}{l}* 1 \text { Major written } \\
\text { warning (1 male ) }\end{array}$ & $\begin{array}{l}25 \% \text { of warnings for } \\
\text { disrupting others, } \\
\text { talking, \& laughing }\end{array}$ & $\begin{array}{l}\text { Not effective enforcement: } \\
\text { Major written Warning is given } \\
\text { with no previous oral or minor } \\
\text { written warnings. }\end{array}$ \\
\hline & & $\begin{array}{l}* 1 \text { Major written } \\
\text { warning ( } 1 \text { male })\end{array}$ & $\begin{array}{l}25 \% \text { of warnings for } \\
\text { disrupting others, } \\
\text { talking, \& laughing }\end{array}$ & $\begin{array}{l}\text { Not effective enforcement: } \\
\text { Major written Warning is given } \\
\text { with I referral observed and with } \\
\text { no previous oral or minor written } \\
\text { warnings. }\end{array}$ \\
\hline & & $\begin{array}{l}\text { * } 1 \text { Minor written } \\
\text { warning ( } 1 \text { male ) }\end{array}$ & $\begin{array}{l}25 \% \text { of warnings for } \\
\text { disrupting others, } \\
\text { talking, \& laughing }\end{array}$ & $\begin{array}{l}\text { Not effective enforcement: } \\
\text { Minor written warning is given } \\
\text { with } 3 \text { referrals observed }\end{array}$ \\
\hline
\end{tabular}




\section{Table E7.}

Number of suspension rate at the Intermediate levels

\begin{tabular}{l|l|c|c|c|}
\hline $\begin{array}{l}\text { Number of suspension } \\
\text { rate at the Intermediate } \\
\text { levels. }\end{array}$ & None & Seventh Grade & Eighth Grade & Ninth Grade \\
\cline { 3 - 5 } & & $0 \%$ & $0 \%$ & $0 \%$ \\
\hline
\end{tabular}

\section{Table E8.}

Written Codes on Rule Infractions, Referrals, and Cumulative Warnings

\begin{tabular}{|c|c|}
\hline $\begin{array}{l}\text { Frequency of different } \\
\text { rule infractions resulting } \\
\text { in referrals (based on } \\
\text { observation) }\end{array}$ & 4 infractions \\
\hline $\begin{array}{l}\text { Consequences for } \\
\text { cumulative warnings }\end{array}$ & $\begin{array}{l}4 \text { oral warning }=1 \text { minor written warning. } \\
3 \text { minor written warnings }=1 \text { major written warning } \rightarrow \text { letter to parent. } \\
2 \text { major written warnings }=1 \text { day of Suspension. } \\
3 \text { major written warnings }=3 \text { days of Suspension. } \\
4 \text { major written warnings }=\text { Exclusion. }\end{array}$ \\
\hline
\end{tabular}

Table E9.

Conditions for Eliminating Warnings from Students ' Discipline Records

\begin{tabular}{|l|l|}
\hline Condition & $\begin{array}{l}\text { The warning is eliminated from students' discipline record in case the rule infraction } \\
\text { is not committed for : }\end{array}$ \\
\hline Oral warning & One week \\
\hline Minor written warnings & Two weeks \\
\hline Major written warnings & Three weeks \\
\hline
\end{tabular}

N.B: Red color reflects important information. 


\section{Appendix $F$}

Provides Codes and Categories for the Research Variables in the following Table:

\begin{tabular}{|c|c|c|c|c|c|c|c|c|c|c|}
\hline \multirow{3}{*}{ 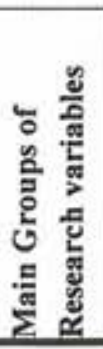 } & \multirow{3}{*}{\multicolumn{2}{|c|}{$\begin{array}{l}\text { Specific Research } \\
\text { Variables }\end{array}$}} & \multirow{3}{*}{ 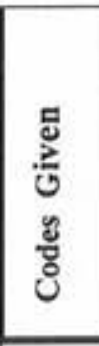 } & \multicolumn{7}{|c|}{ Frequencies in School's Records } \\
\hline & & & & \multicolumn{3}{|c|}{ Discipline Policies } & \multirow{2}{*}{$\begin{array}{l}\text { Total \# } \\
\text { of } \\
\text { repeated } \\
\text { words }\end{array}$} & \multirow[b]{2}{*}{$\begin{array}{c}\text { Manifest } \\
\text { Evaluation }\end{array}$} & \multirow{2}{*}{$\begin{array}{l}\text { \# of } \\
\text { Students } \\
\text { Referrals in } \\
\text { Personnel } \\
\text { Records }\end{array}$} & \multirow{2}{*}{$\begin{array}{l}\text { \# of } \\
\text { Punishme } \\
\text { nt in } \\
\text { Personnel } \\
\text { Records }\end{array}$} \\
\hline & & & & $\begin{array}{c}\text { To } \\
\text { parents }\end{array}$ & $\begin{array}{c}\text { To } \\
\text { Students }\end{array}$ & $\begin{array}{l}\text { Personnel } \\
\text { Enforcem } \\
\text { ent record }\end{array}$ & & & & \\
\hline \multirow{8}{*}{ 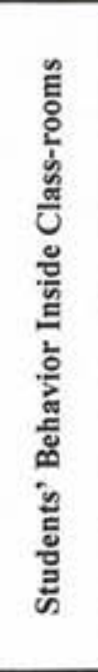 } & \multicolumn{2}{|c|}{ Absenteeism } & 101 & //I// & $1 / 1 / 1 / 1 /$ & /// & 16 & 1 & 0 & \\
\hline & \multicolumn{2}{|c|}{ Tardiness } & 102 & $1 / 1 / 1 /$ & IIIIII /III & // & 18 & 1 & 0 & \\
\hline & \multicolumn{2}{|c|}{ No Homework } & 103 & 1 & $1 / / / 1$ & & 6 & 2 & 48 & \\
\hline & \multicolumn{2}{|c|}{ Forgetting books } & 104 & & / & & 1 & 4 & 19 & \\
\hline & \multicolumn{2}{|c|}{ Disrupting Others } & 105 & 1 & $1 / 1 / 1 /$ & & 8 & 2 & 11 & $/ / 1$ \\
\hline & \multirow{3}{*}{ 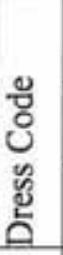 } & Hair & 120 & //I & /II & & 6 & 2 & 0 & \\
\hline & & Jewelry & 130 & I & 11 & & 3 & 4 & 0 & \\
\hline & & Uniform & 140 & $/ / / / /$ & /I/I/// & // & 14 & 1 & 1 & \\
\hline \multirow{3}{*}{ 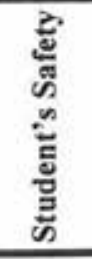 } & \multirow{3}{*}{ 畩 } & Emotionally & 210 & & I & & 1 & 4 & 0 & \\
\hline & & Verbally & 220 & & / & & 1 & 4 & 0 & \\
\hline & & Physically & 230 & & / & & 1 & 4 & 0 & \\
\hline \multirow{7}{*}{ 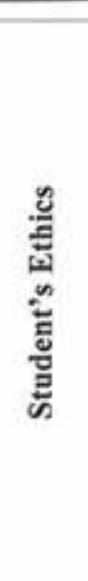 } & \multicolumn{2}{|c|}{ Bad Language } & 310 & $/ 1$ & $\| /$ & & 5 & 2 & 0 & \\
\hline & \multicolumn{2}{|c|}{ Cell-phone } & 320 & I & 11 & & 3 & 4 & 0 & \\
\hline & \multicolumn{2}{|c|}{ Chewing Gum } & 330 & I & 11 & & 3 & 4 & 0 & \\
\hline & \multicolumn{2}{|c|}{ Eating in class } & 340 & I & 11 & & 3 & 4 & 1 & \\
\hline & \multicolumn{2}{|c|}{ Smoking } & 350 & 1 & I & & 2 & 4 & 0 & \\
\hline & \multicolumn{2}{|c|}{ Cheating } & 360 & 1 & I & & 2 & 4 & 1 & / \\
\hline & \multicolumn{2}{|c|}{ Vandalism } & 370 & 1 & $1 / 1 /$ & & 5 & 3 & 0 & \\
\hline
\end{tabular}

Categories within the Manifest Evaluation: 
1 = Highly Repeated;

2 = Somewhat Repeated;

3 = Moderately Repeated;

4 = Slightly Repeated; $5=$ Not Repeated.

Categories within the Subject Evaluation:

$1=$ Highly Enforced;

2 = Somewhat Enforced;

3 = Moderately Enforced;

$4=$ Slightly Enforced;

$5=$ Not Enforced

Colors presented and its reflections:

Black color: The repetition of the word with no consequences

Green color: The repetition with the consequence of oral warning

Blue color: The repetition with the consequence of minor written warning

Red color: The repetition with the consequence of major written warning

Purple color: The repetition with the consequence of suspension 


\section{Appendix $G$}

Table of Latent Analysis for the Research Variables:

\begin{tabular}{|l|l|l|c|}
\hline $\begin{array}{l}\text { Research } \\
\text { Variables }\end{array}$ & $\begin{array}{l}\text { Frequency of Warnings in all } \\
\text { School's Discipline Policies }\end{array}$ & Type of Warning Mentioned & $\begin{array}{c}\text { Latent } \\
\text { Evaluation }\end{array}$ \\
\hline $\begin{array}{l}\text { Smoking } \\
\text { Cheating }\end{array}$ & $/$ & 1 suspension each & 1 \\
\hline Absenteeism & $/ / / / / / /$ & $\begin{array}{l}\text { 2 major written, 5 minor written, \& I oral } \\
\text { warnings }\end{array}$ & 2 \\
\hline Vandalism & $/ / /$ & 2 major written, \& 1 minor written warnings & 2 \\
\hline $\begin{array}{l}\text { Disrupting } \\
\text { Others }\end{array}$ & $\begin{array}{l}\text { 1 major written, 3 minor written, \& 2 oral } \\
\text { warnings }\end{array}$ & 2 \\
\hline $\begin{array}{l}\text { Emotional } \\
\text { Bullying } \\
\text { Verbal Bullying } \\
\text { Physical } \\
\text { Bullying } \\
\text { Bad language }\end{array}$ & $/ / / / /$ & & 3 \\
\hline School Uniform & $/ / / / /$ & 1 major written warning & \\
\hline No H.W & $/ / / /$ & 4 minor written, \& 2 oral warnings & 3 \\
\hline Tardiness & $/ / / / / /$ & 4 minor written warnings & 3 \\
\hline $\begin{array}{l}\text { Cell-phone } \\
\text { Chewing-gum } \\
\text { Eating in } \\
\text { class/Lab/Library } \\
\text { Forgetting books }\end{array}$ & $/$ & 2 minor written, \& 5 oral warnings & 3 \\
\hline Jewelry & $/ /$ & No consequences & 4 \\
\hline Hair & 1 minor written warning & 5 \\
\hline
\end{tabular}

Categories within the Latent Evaluation:

1 = Highly Warned;

4 = Slightly Warned;

2 = Somewhat Warned;

3 = Moderately Warned;

\section{Colors presented and its reflections:}

Green color: The repetition with the consequence of oral warning

Blue color: The repetition with the consequence of minor written warning

Red color: The repetition with the consequence of major written warning

Purple color: The repetition with the consequence of suspension 


\section{Appendix $\mathrm{H}$}

Table Verifying Triangulation of Similar Concepts in the Different Instruments

\begin{tabular}{|c|c|c|c|c|}
\hline $\begin{array}{l}\text { Main } \\
\text { Ideas }\end{array}$ & $\begin{array}{l}\text { Similar Concepts in the Student's \& } \\
\text { Teacher's Questionnaires }\end{array}$ & $\begin{array}{l}\text { Question \# in } \\
\text { Student's } \\
\text { Questionnaire }\end{array}$ & $\begin{array}{l}\text { Question \# in } \\
\text { Teachers' } \\
\text { Questionnaire }\end{array}$ & Observation \\
\hline \multirow{5}{*}{ 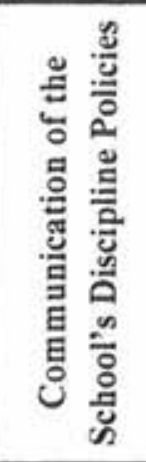 } & $\begin{array}{l}\text { Checking whether school's members } \\
\text { received school's policies booklet }\end{array}$ & Q1 & Q1 & 1 \\
\hline & $\begin{array}{l}\text { Checking whether parents received school's } \\
\text { policies booklet }\end{array}$ & Q2 & Q2 & 1 \\
\hline & Communication of school's policies & Q3 & Q2 & 2 \\
\hline & $\begin{array}{l}\text { Teachers reminded students of school's } \\
\text { discipline rules }\end{array}$ & Q4 & Q3 \& Q4 & 4 \\
\hline & $\begin{array}{l}\text { Students received training on school's } \\
\text { discipline rules }\end{array}$ & Q5 & Q5 & 5 \\
\hline \multirow{5}{*}{ 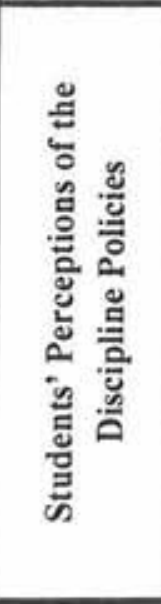 } & $\begin{array}{l}\text { Checking the students understanding of the } \\
\text { school's discipline rules }\end{array}$ & Q6 & Q6 & 1 \\
\hline & $\begin{array}{l}\text { Checking if school has too many discipline } \\
\text { rules }\end{array}$ & Q7 & Q9 & 2 \\
\hline & $\begin{array}{l}\text { Checking the level of involvement of the } \\
\text { students or teachers in the development of } \\
\text { classroom rules }\end{array}$ & Q8 & Q12 \& (Q9 in table) & 5 \\
\hline & $\begin{array}{l}\text { Checking if fair enforcement of the school's } \\
\text { discipline rules is being applied by the } \\
\text { teachers }\end{array}$ & Q9 & $(\mathrm{Q} 2$, \& $\mathrm{Q} 7$ in table $)$ & 3 \\
\hline & $\begin{array}{l}\text { Teachers are too strict on discipline rules } \\
\text { enforcement }\end{array}$ & Q10 & (Q10 in table) & 2 \\
\hline \multirow{3}{*}{ 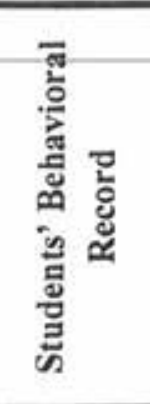 } & $\begin{array}{l}\text { The oral warning that the student may } \\
\text { receive: number or times: and main reason. }\end{array}$ & Q14 & Q25 & 1 \\
\hline & $\begin{array}{l}\text { receive; number or times; and main reason. } \\
\text { The minor written warning that the student } \\
\text { may receive; number or times; and main } \\
\text { reason. }\end{array}$ & Q15 & Q26 & 1 \\
\hline & $\begin{array}{l}\text { The major written warning that the student } \\
\text { may receive; number or times; and main } \\
\text { reason. }\end{array}$ & Q16 & Q27 & 1 \\
\hline \multirow{3}{*}{ 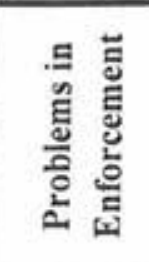 } & $\begin{array}{l}\text { Doing something \&being surprised it is } \\
\text { against school's discipline rules }\end{array}$ & Q11 & Q16 \& (Q7 in table) & 2 \\
\hline & $\begin{array}{l}\text { Student gets away with violating discipline } \\
\text { rules }\end{array}$ & Q12 & Q5 (table) & 2 \\
\hline & Being blamed when it is not student's fault & Q13 & (Q3 in table) & 4 \\
\hline
\end{tabular}




\begin{tabular}{|c|c|c|c|c|}
\hline \multirow{2}{*}{ 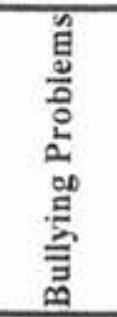 } & Whether school is a safe place from bullies & Q17 & Q28 \& Q30 & 3 \\
\hline & Student contact after being bullied & Q18 & Q29 & 4 \\
\hline \multirow{3}{*}{ 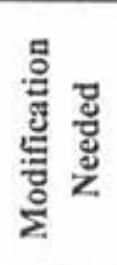 } & $\begin{array}{l}\text { The steps needed to control students' } \\
\text { bullying }\end{array}$ & Q19 & Q31 \& Q32 & 4 \\
\hline & $\begin{array}{l}\text { The school discipline rule that should be } \\
\text { changed }\end{array}$ & Q20 & $\begin{array}{c}\text { (Q1,Q3,Q4,Q6, \& } \\
\text { Q8 in table) }\end{array}$ & 3 \\
\hline & The discipline rule that is missing & Q21 & Q33 & 4 \\
\hline
\end{tabular}

\section{Evaluation Categories based on Observation:}

1=Mostly achieved; 2 =Quite achieved; 3 =moderately achieved; 4 =slightly achieved; $5=$ No 


\section{Appendix I}

Table Verifying Triangulation of Alternative Concepts in Teachers' Questionnaire:

\begin{tabular}{|c|c|c|c|c|c|}
\hline Main Ideas & $\begin{array}{l}\text { Alternative Concepts in Teacher's } \\
\text { Questionnaire }\end{array}$ & Comments & $\begin{array}{l}\text { Question \# in } \\
\text { the Teachers' } \\
\text { Questionnaire }\end{array}$ & Observation & $\begin{array}{l}\text { Supervisors } \\
\text { Interview }\end{array}$ \\
\hline \multirow{6}{*}{ 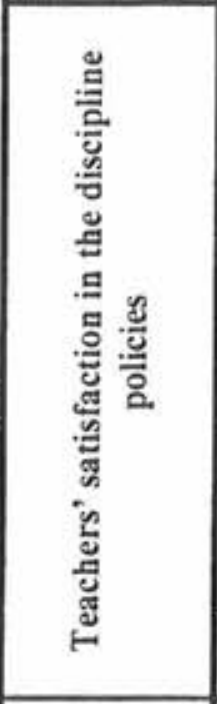 } & $\begin{array}{l}\text { Teacher accept the school's } \\
\text { philosophy regarding students' } \\
\text { discipline }\end{array}$ & Acceptance & Q7 & 2 & \\
\hline & $\begin{array}{l}\text { Teachers' agreement with the } \\
\text { administrator's management }\end{array}$ & Problem & Q18 & & \\
\hline & $\begin{array}{l}\text { Teachers support the school's } \\
\text { procedures concerning students' } \\
\text { discipline rules }\end{array}$ & Acceptance & Q8 & 2 & \\
\hline & $\begin{array}{l}\text { Teachers' involvement in the } \\
\text { development of school's discipline } \\
\text { policies }\end{array}$ & Initiation & Q10 & & \\
\hline & $\begin{array}{l}\text { Teachers' preference on being } \\
\text { involved in the decision on school's } \\
\text { discipline policies }\end{array}$ & Problem & Q11 & & \\
\hline & $\begin{array}{l}\text { Teachers' satisfaction with school's } \\
\text { discipline implementation }\end{array}$ & Enforcement & Q14 & & \\
\hline \multirow{2}{*}{ 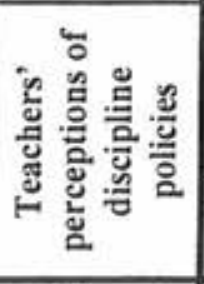 } & $\begin{array}{l}\text { Checking whether students meet } \\
\text { personnel's expectations in making } \\
\text { their own decisions about obeying } \\
\text { rules. }\end{array}$ & Acceptance & Q13 & & \\
\hline & $\begin{array}{l}\text { The most effective implementation } \\
\text { of school discipline policy }\end{array}$ & Enforcement & Q15 & & \\
\hline \multirow{7}{*}{ 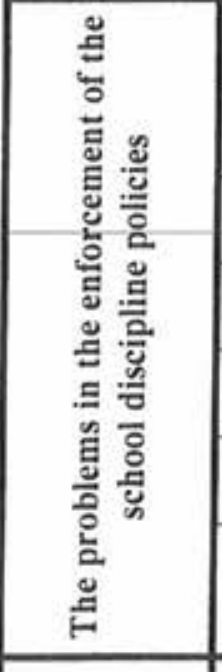 } & $\begin{array}{l}\text { The least effective implementation } \\
\text { of school discipline policy }\end{array}$ & Problem & Q16 & & \\
\hline & $\begin{array}{l}\text { Students' indiscipline behavior that } \\
\text { is causing stress }\end{array}$ & Problem & Q17 & & \\
\hline & $\begin{array}{l}\text { Checking whether sch. Discipline } \\
\text { problems are †or } \downarrow\end{array}$ & Problem & Q19 & & \\
\hline & $\begin{array}{l}\text { Effect of school's discipline } \\
\text { policies on students' tardiness }\end{array}$ & Problem & Q20 & & \\
\hline & $\begin{array}{l}\text { Effect of school's discipline } \\
\text { policies on students' class cuts }\end{array}$ & Problem & Q21 & & \\
\hline & $\begin{array}{l}\text { School is or isn't facing students' } \\
\text { discipline problems }\end{array}$ & Problem & Q22 & & \\
\hline & $\begin{array}{l}\text { Time wasted by teachers on the } \\
\text { enforcement of school's discipline } \\
\text { rules }\end{array}$ & Problem & Q24 & & \\
\hline $\begin{array}{l}\text { Modificati } \\
\text { on needed }\end{array}$ & $\begin{array}{l}\text { Checking whether school's } \\
\text { discipline policies need change }\end{array}$ & Modification & Q23 & & \\
\hline
\end{tabular}




\begin{tabular}{|c|l|l|c|l|l|}
\hline $\begin{array}{c}\text { Teachers' } \\
\text { History }\end{array}$ & Years of teaching in school & History & Q34 & & \\
\cline { 2 - 5 } & Years of teaching & History & Q35 & & \\
\hline
\end{tabular}

Evaluation Categories based on Observation:

I=Mostly achieved; 2 = Quite achieved; 3 =moderately achieved; 4 =slightly achieved; $5=$ No 


\section{Appendix J}

Table Presenting the Summary of Data Received from the Students' Questionnaire:

\begin{tabular}{|c|c|c|c|c|c|c|c|c|c|c|}
\hline \multirow{4}{*}{$\begin{array}{l}\text { Question } \\
\text { Number }\end{array}$} & \multicolumn{10}{|c|}{ STUDENTS' QUESTIONNAIRES } \\
\hline & \multicolumn{10}{|c|}{ Students' Answers } \\
\hline & \multicolumn{10}{|c|}{ Number of Students \& Correspondent Percentages } \\
\hline & YES & NO & A & B & C & D & $\mathrm{E}$ & F & G & Total\% \\
\hline 1 & $\begin{array}{c}108= \\
96.43 \%\end{array}$ & $\begin{array}{c}4= \\
3.57 \%\end{array}$ & & & & & & & & $100 \%$ \\
\hline 2 & $\begin{array}{c}87= \\
77.68 \%\end{array}$ & $\begin{array}{c}22= \\
19.64 \%\end{array}$ & & & & & & & & $97.32 \%$ \\
\hline 3 & & & $\begin{array}{c}23= \\
20.54 \%\end{array}$ & $\begin{array}{c}35= \\
31.25 \%\end{array}$ & $\begin{array}{c}5= \\
4.46 \%\end{array}$ & $\begin{array}{c}27= \\
24.11 \%\end{array}$ & $\begin{array}{c}5= \\
4.46 \%\end{array}$ & $\begin{array}{c}7= \\
6.25 \%\end{array}$ & & $94.64 \%$ \\
\hline 4 & & & $0=0 \%$ & $\begin{array}{c}76= \\
67.86 \%\end{array}$ & $\begin{array}{c}14= \\
12.5 \%\end{array}$ & $\begin{array}{c}19= \\
16.96 \%\end{array}$ & & & & $97.32 \%$ \\
\hline 5 & & & $\begin{array}{c}29= \\
25.89 \%\end{array}$ & $\begin{array}{c}12= \\
10.71 \%\end{array}$ & $\begin{array}{c}6= \\
5.36 \%\end{array}$ & $\begin{array}{c}4= \\
3.57 \%\end{array}$ & $\begin{array}{c}47= \\
41.96 \%\end{array}$ & & & $87.5 \%$ \\
\hline 6 & & & $\begin{array}{c}78= \\
69.64 \%\end{array}$ & $\begin{array}{c}29= \\
25.89 \%\end{array}$ & $\begin{array}{c}1= \\
0.89 \%\end{array}$ & & & & & $96.43 \%$ \\
\hline 7 & $\begin{array}{c}85= \\
75.89 \%\end{array}$ & $\begin{array}{c}24= \\
21.43 \%\end{array}$ & & & & & & & & $97.32 \%$ \\
\hline 8 & $\begin{array}{c}48= \\
42.86 \%\end{array}$ & $\begin{array}{c}59= \\
52.68 \%\end{array}$ & & & & & & & & $95.54 \%$ \\
\hline 9 & $\begin{array}{c}67= \\
59.82 \%\end{array}$ & $\begin{array}{c}44= \\
39.29 \%\end{array}$ & & & & & & & & $99.11 \%$ \\
\hline 10 & $\begin{array}{c}81 \\
=72.32 \%\end{array}$ & $\begin{array}{c}30= \\
26.79 \%\end{array}$ & & & & & & & & $99.11 \%$ \\
\hline 11 & $\begin{array}{c}49= \\
43.75 \%\end{array}$ & $\begin{array}{c}57= \\
50.89 \%\end{array}$ & & & & & & & & $94,64 \%$ \\
\hline 12 & & & $\begin{array}{c}22= \\
19.64 \%\end{array}$ & $\begin{array}{c}72= \\
64.29 \%\end{array}$ & $\begin{array}{c}14= \\
12.5 \%\end{array}$ & & & & & $96.43 \%$ \\
\hline 13 & & & $\begin{array}{c}40= \\
35.71 \%\end{array}$ & $\begin{array}{c}19= \\
16.96 \%\end{array}$ & $\begin{array}{c}49= \\
43.75 \\
\%\end{array}$ & & & & & $96.43 \%$ \\
\hline
\end{tabular}




\begin{tabular}{|c|c|c|c|c|c|c|c|c|c|c|}
\hline 14 & $\begin{array}{c}27= \\
24.11 \%\end{array}$ & $\begin{array}{l}84= \\
75 \%\end{array}$ & & & & & & & & $99.11 \%$ \\
\hline 15 & $11=9.82 \%$ & $\begin{array}{c}100= \\
89.29 \%\end{array}$ & & & & & & & & $99.11 \%$ \\
\hline 16 & $6=5.36 \%$ & $\begin{array}{c}105= \\
93.75 \%\end{array}$ & & & & & & & & $99.11 \%$ \\
\hline 17 & $\begin{array}{c}92= \\
82.14 \%\end{array}$ & $\begin{array}{c}17= \\
15.18 \%\end{array}$ & & & & & & & & $97.32 \%$ \\
\hline 18 & & & $\begin{array}{l}22= \\
19.64 \%\end{array}$ & $\begin{array}{l}23= \\
20.54 \%\end{array}$ & $\begin{array}{l}5= \\
4.46 \%\end{array}$ & $\begin{array}{l}13= \\
11.61 \%\end{array}$ & $\begin{array}{l}11= \\
9.82 \%\end{array}$ & $\begin{array}{l}14= \\
12.5 \%\end{array}$ & $\begin{array}{l}3= \\
2.68 \%\end{array}$ & $95.52 \%$ \\
\hline 19 & & & $\begin{array}{l}4= \\
3.57 \%\end{array}$ & $\begin{array}{l}61= \\
54.46 \%\end{array}$ & $\begin{array}{l}17= \\
15.18 \\
\%\end{array}$ & $\begin{array}{l}22= \\
19.64 \%\end{array}$ & & & & $92.86 \%$ \\
\hline 20 & & & & & & & $\frac{15}{3 x^{2}}$ & & & $99.91 \%$ \\
\hline 21 & $x 3$ & & $\sqrt{2}$ & 4 & & & & & & $99.07 \%$ \\
\hline
\end{tabular}




\section{Appendix $K$}

Table Presenting the Data from the Student's Questionnaires:

\begin{tabular}{|c|c|c|c|c|c|}
\hline Main Ideas & Q\# & \begin{tabular}{|l} 
Similar Concepts in the \\
Students'\& Teachers' \\
Questionnaires with Total \\
Students' Respondents \\
\end{tabular} & Students' Responses & $\begin{array}{l}\text { Students' } \\
\text { Total \# }\end{array}$ & $\begin{array}{l}\text { Students' } \\
\text { Percentage }\end{array}$ \\
\hline \multirow{5}{*}{$\begin{array}{l}\text { School's } \\
\text { communicat- } \\
\text { ion on their } \\
\text { Discipline } \\
\text { Policies }\end{array}$} & 1 & $\begin{array}{l}\text { Checking whether students } \\
\text { received school's discipline } \\
\text { policies booklet }(100 \%)\end{array}$ & $\begin{array}{l}\text { Yes } \\
\text { No }\end{array}$ & $\begin{array}{l}108 \\
4\end{array}$ & $\begin{array}{l}96.43 \% \\
3.57 \%\end{array}$ \\
\hline & 2 & $\begin{array}{l}\text { Checking whether parents } \\
\text { received school's policies } \\
\text { booklet }(97.32 \%)\end{array}$ & $\begin{array}{l}\text { Yes } \\
\text { No }\end{array}$ & $\begin{array}{l}87 \\
22\end{array}$ & $\begin{array}{l}77.68 \% \\
19.64 \%\end{array}$ \\
\hline & 3 & $\begin{array}{l}\text { Communication of school's } \\
\text { policies }(94.64 \%)\end{array}$ & $\begin{array}{l}\text { A) School's Newsletters } \\
\text { B) Handbooks } \\
\text { C) Students' Meetings } \\
\text { D) Parents' Meeting } \\
\text { E) Others } \\
\text { F) Not Applicable } \\
\text { A \& C } \\
\text { B \& D } \\
\text { D \& E (advisor) }\end{array}$ & $\begin{array}{l}23 \\
35 \\
5 \\
27 \\
5 \\
7 \\
2 \\
1 \\
1 \\
\end{array}$ & \begin{tabular}{|l|}
$20.54 \%$ \\
$31.25 \%$ \\
$4.46 \%$ \\
$24.11 \%$ \\
$4.46 \%$ \\
$6.25 \%$ \\
$1.79 \%$ \\
$0.89 \%$ \\
$0.89 \%$ \\
\end{tabular} \\
\hline & 4 & $\begin{array}{l}\text { Teachers reminded students } \\
\text { of school's discipline rules } \\
(97.32 \%)\end{array}$ & $\begin{array}{l}\text { A) After the Winter Vacations } \\
\text { B) After the Summer Vacations } \\
\text { C) After both Vacations } \\
\text { D) No }\end{array}$ & $\begin{array}{l}0 \\
76 \\
14 \\
19\end{array}$ & $\begin{array}{l}0 \% \\
67.86 \% \\
12.5 \% \\
16.96 \%\end{array}$ \\
\hline & 5 & $\begin{array}{l}\text { Students received training } \\
\text { on school's discipline rules } \\
(87.5 \%)\end{array}$ & $\begin{array}{l}\text { A) One Day of Training } \\
\text { B) Two Days of Training } \\
\text { C) One Week of Training } \\
\text { D) Two Weeks of Training } \\
\text { E) No Training } \\
\end{array}$ & $\begin{array}{l}29 \\
12 \\
6 \\
4 \\
47 \\
\end{array}$ & $\begin{array}{l}25.89 \% \\
10.71 \% \\
5.36 \% \\
3.57 \% \\
41.96 \% \\
\end{array}$ \\
\hline \multirow{3}{*}{$\begin{array}{l}\text { Students' } \\
\text { Perceptions } \\
\text { of the } \\
\text { Discipline } \\
\text { Policies }\end{array}$} & 6 & $\begin{array}{l}\text { Students clearly understand } \\
\text { the school's rules }(96.43 \%)\end{array}$ & $\begin{array}{l}\text { A) All } \\
\text { B) Some } \\
\text { C) None }\end{array}$ & $\begin{array}{l}78 \\
29 \\
1\end{array}$ & $\begin{array}{l}69.64 \% \\
25.89 \% \\
0.89 \%\end{array}$ \\
\hline & 7 & $\begin{array}{l}\text { Students think that the } \\
\text { school has too many rules } \\
(97.32 \%)\end{array}$ & $\begin{array}{l}\text { A) Yes } \\
\text { B) No }\end{array}$ & $\begin{array}{l}85 \\
24\end{array}$ & $\begin{array}{l}75.89 \% \\
21.43 \%\end{array}$ \\
\hline & 8 & $\begin{array}{l}\text { Students are involved in the } \\
\text { development of their } \\
\text { classroom rules }(95.54 \%)\end{array}$ & $\begin{array}{l}\text { A) Yes } \\
\text { B) No }\end{array}$ & $\begin{array}{l}48 \\
59\end{array}$ & $\begin{array}{l}42.86 \% \\
52.68 \% \\
\end{array}$ \\
\hline \multirow{2}{*}{$\begin{array}{l}\text { Students' } \\
\text { Perceptions } \\
\text { of the } \\
\text { Discipline } \\
\text { Policies }\end{array}$} & 9 & $\begin{array}{l}\text { Students believed that the } \\
\text { rules are fairly enforced in } \\
\text { the school }(99.11 \%)\end{array}$ & $\begin{array}{l}\text { A) Yes } \\
\text { B) No }\end{array}$ & $\begin{array}{l}67 \\
44\end{array}$ & $\begin{array}{l}59.82 \% \\
39.29 \%\end{array}$ \\
\hline & 10 & $\begin{array}{l}\text { Most of teachers are too } \\
\text { strict on discipline rules } \\
\text { enforcement }(99.11 \%)\end{array}$ & $\begin{array}{l}\text { A) Yes } \\
\text { B) No }\end{array}$ & $\begin{array}{l}81 \\
30\end{array}$ & $\begin{array}{l}72.32 \% \\
26.79 \%\end{array}$ \\
\hline
\end{tabular}




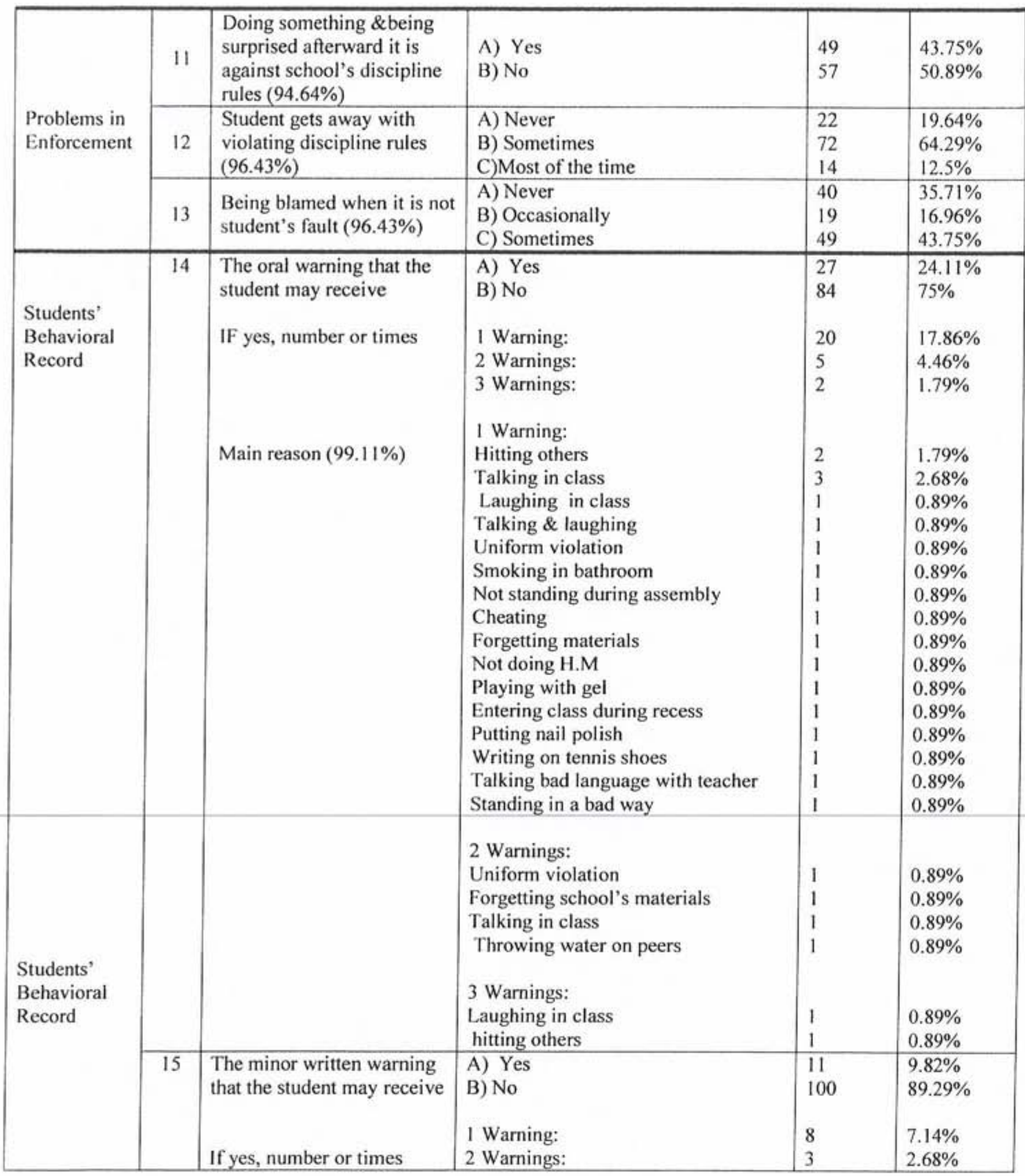




\begin{tabular}{|c|c|c|c|c|c|}
\hline \multirow[b]{2}{*}{. } & & Main reason $(99.11 \%)$ & $\begin{array}{l}1 \text { Warning: } \\
\text { No H.W } \\
\text { Forgetting school's materials } \\
\text { Talking } \\
\text { Uniform } \\
\text { Aggressive with peers } \\
\text { Playing with cell-phone } \\
2 \text { Warnings: } \\
\text { Laughing in class } \\
\text { Talking in class } \\
\text { Laughing \& Talking in class }\end{array}$ & $\begin{array}{l}2 \\
2 \\
1 \\
1 \\
1 \\
1 \\
1 \\
1 \\
1 \\
1\end{array}$ & $\begin{array}{l}1.79 \% \\
1.79 \% \\
0.89 \% \\
0.89 \% \\
0.89 \% \\
0.89 \% \\
\\
\\
\\
0.89 \% \\
0.89 \% \\
0.89 \%\end{array}$ \\
\hline & 16 & $\begin{array}{l}\text { The major written warning } \\
\text { that the student may receive } \\
\text { If yes, number or times } \\
\text { Main reason }(99.11 \%)\end{array}$ & $\begin{array}{l}\text { A) Yes } \\
\text { B) No } \\
\text { I Warning: } \\
\text { Bad behavior } \\
\text { Laughing in class } \\
\text { Laughing \& Talking in class } \\
\text { Eating in class } \\
\text { Not knowing the reason } \\
\text { Wasn't student's fault }\end{array}$ & $\begin{array}{l}6 \\
105 \\
6 \\
1 \\
1 \\
1 \\
1 \\
1 \\
1 \\
\end{array}$ & $\begin{array}{l}5.36 \% \\
93.75 \% \\
\\
5.36 \% \\
\\
0.89 \% \\
0.89 \% \\
0.89 \% \\
0.89 \% \\
0.89 \% \\
0.89 \% \\
\end{array}$ \\
\hline & 17 & $\begin{array}{l}\text { Students feel that the school } \\
\text { is a safe place from bullies } \\
(97.32 \%)\end{array}$ & $\begin{array}{l}\text { A) Yes } \\
\text { B) No }\end{array}$ & $\begin{array}{l}92 \\
17\end{array}$ & $\begin{array}{l}82.14 \% \\
15.18 \%\end{array}$ \\
\hline & & & $\begin{array}{l}\text { A) Your friend } \\
\text { B) Your parents } \\
\text { C) Your teacher } \\
\text { D) The school's counselor/ advisor } \\
\text { E) The school's supervisor } \\
\text { F) Nobody } \\
\text { G) others }\end{array}$ & $\begin{array}{l}22 \\
23 \\
5 \\
13 \\
11 \\
14 \\
3\end{array}$ & $\begin{array}{l}19.64 \% \% \\
20.54 \% \\
4.46 \% \\
11.61 \% \\
9.82 \% \\
12.5 \% \\
2.68 \%\end{array}$ \\
\hline $\begin{array}{l}\text { Bullying } \\
\text { Problems }\end{array}$ & 18 & $\begin{array}{l}\text { In case of being bullied, } \\
\text { students contact }(95.52 \%)\end{array}$ & $\begin{array}{l}\text { A \& B } \\
\text { A \& C } \\
\text { B \& C } \\
\text { B \& E } \\
\text { B \& G } \\
\text { C \& D } \\
\text { C \& E } \\
\text { D \& E } \\
\text { A, B, \& C } \\
\text { A, B, \& E } \\
\text { C, D \& E } \\
\text { A, B, C, \& E }\end{array}$ & $\begin{array}{l}5 \\
1 \\
3 \\
3 \\
1 \\
2 \\
1 \\
1 \\
1 \\
1 \\
1 \\
1 \\
1 \\
\end{array}$ & $\begin{array}{l}4.46 \% \\
0.89 \% \\
2.68 \% \\
2.68 \% \\
0.89 \% \\
1.79 \% \\
0.89 \% \\
0.89 \% \\
0.89 \% \\
0.89 \% \\
0.89 \% \\
0.89 \% \\
\end{array}$ \\
\hline
\end{tabular}




\begin{tabular}{|c|c|c|c|c|c|}
\hline $\begin{array}{l}\text { Bullying } \\
\text { Problems }\end{array}$ & 19 & $\begin{array}{l}\text { The steps needed to control } \\
\text { students' bullying }(92.86 \%)\end{array}$ & $\begin{array}{l}\text { A) Hallways } \\
\text { B) Playground } \\
\text { C) Bathrooms } \\
\text { D) Others: } \\
\text { A \& B } \\
\text { A, B, \& C } \\
\text { None } \\
\text { Everywhere } \\
\text { In classes } \\
\text { Didn't specify }\end{array}$ & $\begin{array}{l}4 \\
61 \\
17 \\
22 \\
(5) \\
(7) \\
(3) \\
(2) \\
(1) \\
(4) \\
\end{array}$ & $\begin{array}{l}3.57 \% \\
54.46 \% \\
15.18 \% \\
19.64 \% \\
(4.46 \%) \\
(6.25 \%) \\
(2.68 \%) \\
(1.79 \%) \\
(0.89 \%) \\
(3.57 \%)\end{array}$ \\
\hline $\begin{array}{l}\text { Modification } \\
\text { Needed }\end{array}$ & 20 & & $\begin{array}{l}\text { None } \\
\text { Uniform rule: } \\
\text { Uniform } \\
\text { Uniform \& Piercing } \\
\text { Uniform \& nail polish } \\
\text { Uniform \& classrooms' chairs } \\
\text { Uniform \& canteen } \\
\text { Hair code: } \\
\text { Hair code } \\
\text { Hair code \& Jewelry } \\
\text { Hair code, nail-polish, piercing } \\
\text { Hair code, nail-polish, make-up } \\
\text { Jewelry code: } \\
\text { Jewelry } \\
\text { Jewelry \& cell-phone } \\
\text { Jewelry \& hair code (repeated) } \\
\text { Cell-phone code: } \\
\text { Cell-phone rule } \\
\text { Cell-phone rule \& hair code } \\
\text { Cell-phone, \& jewelry (repeated) } \\
\text { Talking rule: } \\
\text { Talking in corridors } \\
\text { Talking without permission } \\
\text { Leisure time rule: }\end{array}$ & \begin{tabular}{|l}
50 \\
22 \\
$(18)$ \\
$(1)$ \\
$(1)$ \\
$(1)$ \\
$(1)$ \\
6 \\
$(2)$ \\
$(2)$ \\
$(1)$ \\
$(1)$ \\
4 \\
$(1)$ \\
$(1)$ \\
$(2)$ \\
7 \\
$(5)$ \\
$(1)$ \\
$(1)$ \\
2 \\
$(1)$ \\
$(1)$ \\
8 \\
\end{tabular} & $\begin{array}{l}44.64 \% \\
19.64 \% \\
(16.07 \%) \\
(0.89 \%) \\
(0.89 \%) \\
(0.89 \%) \\
(0.89 \%) \\
5.36 \% \\
(1.79 \%) \\
(1.79 \%) \\
(0.89 \%) \\
(0.89 \%) \\
3.57 \% \\
(0.89 \%) \\
(0.89 \%) \\
(1.79 \%) \\
6.25 \% \\
(4.46 \%) \\
(0.89 \%) \\
(0.89 \%) \\
1.79 \% \\
(0.89 \%) \\
(0.89 \%) \\
7.24 \% \\
\end{array}$ \\
\hline & & $\begin{array}{l}\text { The school discipline rule } \\
\text { that needs changing } \\
(99.91 \%)\end{array}$ & $\begin{array}{l}\text { Playing football during recess } \\
\text { More Trips } \\
\text { More activities } \\
\text { No parties rule } \\
\text { Classroom rule: } \\
\text { Going to bathroom between hours } \\
\text { Chewing gum rule } \\
\text { Drinking water in class } \\
\text { Not a lot of books } \\
\text { All rules } \\
\text { Make-up \& nail polish rule } \\
\text { Absenteeism code } \\
\text { Being removed from honor list for } \\
\text { bad behavior }\end{array}$ & $\begin{array}{l}(3) \\
(2) \\
(2) \\
(1) \\
4 \\
(1) \\
(1) \\
(1) \\
(1) \\
8 \\
2 \\
1 \\
1\end{array}$ & $\begin{array}{l}(2.68 \%) \\
(1.79 \%) \\
(1.79 \%) \\
(0.89 \%) \\
3.57 \% \\
(0.89 \%) \\
(0.89 \%) \\
(0.89 \%) \\
(0.89 \%) \\
7.14 \% \\
1.79 \% \\
0.89 \% \\
0.89 \%\end{array}$ \\
\hline
\end{tabular}




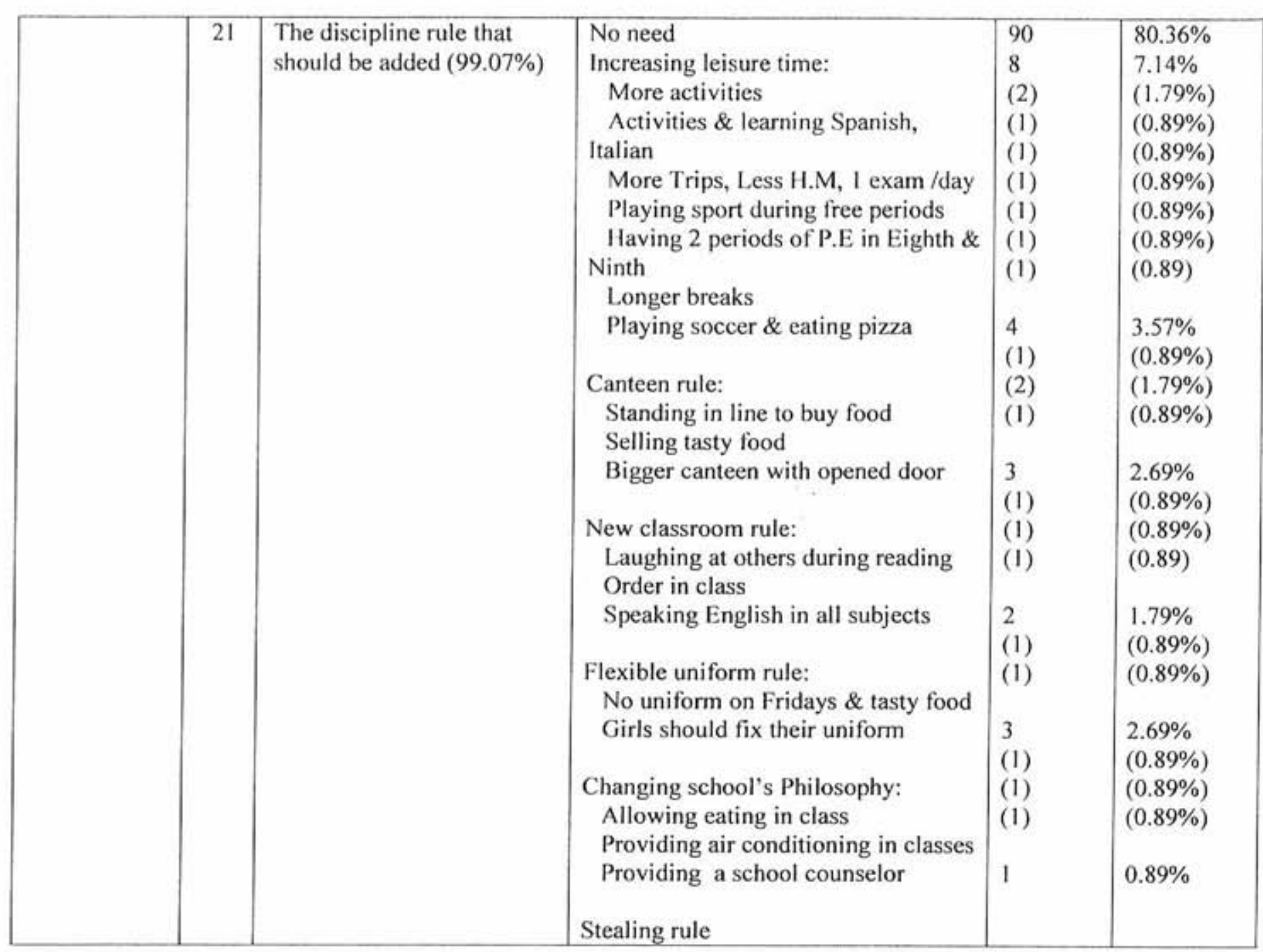




\section{Appendix $L$}

Table Presenting the Summary of Data Received from the Teachers' Questionnaire:

\begin{tabular}{|c|c|c|c|c|c|c|c|c|c|c|}
\hline \multicolumn{11}{|c|}{ TEACHERS' QUESTIONNAIRES } \\
\hline \multirow{3}{*}{$\mathrm{Q} \#$} & \multicolumn{10}{|c|}{ Teachers' Answers } \\
\hline & \multicolumn{10}{|c|}{ Number of teachers \& Correspondent Percentages } \\
\hline & YES & NO & $\Lambda$ & B & $\mathrm{C}$ & $\mathrm{D}$ & $\mathrm{E}$ & $\mathrm{F}$ & G & $\begin{array}{c}\text { Total } \\
\%\end{array}$ \\
\hline \multirow{2}{*}{1} & $17=94 \%$ & & & & & & & & & $94 \%$ \\
\hline & & & $17=94 \%$ & & & & & & & $94 \%$ \\
\hline \multirow[b]{2}{*}{2} & & & $3=17 \%$ & $5=28 \%$ & $5=28 \%$ & 0 & 0 & $4=22 \%$ & $1=6 \%$ & $100 \%$ \\
\hline & & & & & . & & & $\begin{array}{c}2=11 \% \\
1=6 \% \\
1=6 \%\end{array}$ & & $22 \%$ \\
\hline \multirow[b]{3}{*}{3} & $17=94 \%$ & $1=6 \%$ & & & & & & & & $100 \%$ \\
\hline & & & 0 & $5=28 \%$ & $4=22 \%$ & $1=6 \%$ & $7=39 \%$ & & & $94 \%$ \\
\hline & & & & & & & $\begin{array}{c}4=22 \% \\
2=11 \% \\
1=6 \%\end{array}$ & & & $39 \%$ \\
\hline 4 & & & $7=39 \%$ & $8=44 \%$ & $2=11 \%$ & & & & & $94 \%$ \\
\hline \multirow{3}{*}{5} & $11=61 \%$ & $6=33 \%$ & & & & & & & & $94 \%$ \\
\hline & $11=61 \%$ & & & & & & & & & $61 \%$ \\
\hline & $6=33 \%$ & & & & & & & & & $33 \%$ \\
\hline \multirow{2}{*}{6} & $13=72 \%$ & $5=28 \%$ & & & & & & & & $100 \%$ \\
\hline & & $5=28 \%$ & & & & & & & & $28 \%$ \\
\hline 7 & & & $10=56 \%$ & $7=39 \%$ & $1=6 \%$ & & & & & $100 \%$ \\
\hline 8 & & & $10=56 \%$ & $6=33 \%$ & $2=11 \%$ & & & & & $100 \%$ \\
\hline 9 & $2=11 \%$ & $15=83 \%$ & & & & & & & & $94 \%$ \\
\hline \multirow{2}{*}{10} & $2=11 \%$ & $16=89 \%$ & & & & & & & & $100 \%$ \\
\hline & $2=100 \%$ & & & & & & & & & $100 \%$ \\
\hline 11 & & & $8=44 \%$ & $1=6 \%$ & $8=44 \%$ & & & & & $94 \%$ \\
\hline 12 & & & $2=11 \%$ & $5=28 \%$ & $2=11 \%$ & $\begin{array}{c}8=44 \\
\%\end{array}$ & & & & $94 \%$ \\
\hline 13 & & & $10=56 \%$ & $7=39 \%$ & $I=6 \%$ & & & & & $100 \%$ \\
\hline \multirow{2}{*}{14} & $16=89 \%$ & $2=11 \%$ & & & & & & & & $100 \%$ \\
\hline & & $2=100 \%$ & & & & & & & & $100 \%$ \\
\hline 15 & & & & & & & & & $10=56 \%$ & $56 \%$ \\
\hline
\end{tabular}




\begin{tabular}{|c|c|c|c|c|c|c|c|c|c|c|}
\hline Q\# & YES & NO & A & B & $\mathrm{C}$ & D & $\mathrm{E}$ & $\mathrm{F}$ & G & $\begin{array}{c}\text { Total } \\
\%\end{array}$ \\
\hline 16 & & & & & & & & & $8=44 \%$ & $44 \%$ \\
\hline 17 & & & & & & & & & $14=78 \%$ & $78 \%$ \\
\hline 18 & & & $10=56 \%$ & $5=28 \%$ & $1=6 \%$ & & & & & $89 \%$ \\
\hline 19 & & & $7=39 \%$ & $3=17 \%$ & $6=33 \%$ & & & & & $89 \%$ \\
\hline 20 & & & $1=6 \%$ & $5=28 \%$ & $6=33 \%$ & & & & & $67 \%$ \\
\hline 21 & & & $1=6 \%$ & $6=33 \%$ & $6=33 \%$ & & & & & $72 \%$ \\
\hline 22 & & & $1=6 \%$ & $10=56 \%$ & $7=39 \%$ & & & & & $100 \%$ \\
\hline 23 & & & $6=33 \%$ & $10=56 \%$ & $2=11 \%$ & & & & & $100 \%$ \\
\hline 24 & & & $15=83 \%$ & $2=11 \%$ & 0 & $1=6 \%$ & & & & $100 \%$ \\
\hline \multirow{3}{*}{25} & $10=56 \%$ & $8=44 \%$ & & & & & & & & $100 \%$ \\
\hline & $\begin{array}{c}1=6 \% \\
3=17 \% \\
1=6 \% \\
1=6 \% \\
2=11 \% \\
2=11 \%\end{array}$ & & & & & & & & & $56 \%$ \\
\hline & $8=44 \%$ & & & & & & & & & $44 \%$ \\
\hline \multirow{3}{*}{26} & $5=28 \%$ & $13=72 \%$ & & & & & & & & $100 \%$ \\
\hline & $\begin{array}{c}1=6 \% \\
2=11 \% \\
1=6 \% \\
1=6 \% \\
2=11 \%\end{array}$ & & & & & & & & & $28 \%$ \\
\hline & $\begin{array}{l}2=11 \% \\
1=6 \% \\
I=6 \% \\
I=6 \%\end{array}$ & & & & & & & & & $28 \%$ \\
\hline \multirow{3}{*}{27} & $3=17 \%$ & $15=83 \%$ & & & & & & & & $100 \%$ \\
\hline & $\begin{array}{c}2=11 \% \\
1=6 \%\end{array}$ & & & & & & & & & $17 \%$ \\
\hline & $\begin{array}{l}1=6 \% \\
l=6 \%\end{array}$ & & & & & & & & & $11 \%$ \\
\hline 28 & $5=28 \%$ & $12=67 \%$ & & & & & & & & $94 \%$ \\
\hline
\end{tabular}


Effective Enforcement $\quad 146$

\begin{tabular}{|c|c|c|c|c|c|c|c|c|c|c|}
\hline Q\# & YES & NO & A & B & C & D & $\mathrm{E}$ & $\mathrm{F}$ & G & $\begin{array}{c}\text { Total } \\
\%\end{array}$ \\
\hline \multirow{2}{*}{29} & $7=39 \%$ & $11=61 \%$ & & & & & & & & $100 \%$ \\
\hline & $5=28 \%$ & & & & & & & & & $28 \%$ \\
\hline \multirow[b]{2}{*}{30} & $\begin{array}{c}18=100 \\
\%\end{array}$ & 0 & & & & & & & & $100 \%$ \\
\hline & $\begin{array}{l}7=39 \% \\
3=17 \% \\
1=6 \% \\
1=6 \% \\
1=6 \% \\
1=6 \%\end{array}$ & & & & & & & & . & $78 \%$ \\
\hline \multirow[t]{2}{*}{31} & & 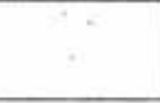 & 0 & $3=17 \%$ & $1=6 \%$ & $\begin{array}{c}13=72 \\
\%\end{array}$ & $1=6 \%$ & & & $100 \%$ \\
\hline & & & & & & & $I=6 \%$ & & & $6 \%$ \\
\hline 32 & & & $9=50 \%$ & 0 & 0 & $\begin{array}{c}2=11 \\
\%\end{array}$ & $4=22 \%$ & $2=11 \%$ & & $94 \%$ \\
\hline 33 & $\begin{array}{l}1=6 \% \\
1=6 \%\end{array}$ & $16=89 \%$ & & & & & & & & $100 \%$ \\
\hline 34 & & & $1=6 \%$ & $2=11 \%$ & 0 & $1=6 \%$ & $\begin{array}{c}14=78 \\
\%\end{array}$ & & & $100 \%$ \\
\hline 35 & & & $1=6 \%$ & 0 & $2=11 \%$ & $\begin{array}{c}15=83 \\
\%\end{array}$ & & & & $100 \%$ \\
\hline
\end{tabular}




\section{Appendix $M$}

Table Presenting the Data from the Teachers' Questionnaire: (First Part)

\begin{tabular}{|c|c|c|c|c|c|}
\hline Main Ideas & $\begin{array}{l}\text { Q } \\
\#\end{array}$ & $\begin{array}{l}\text { Similar Concepts in the } \\
\text { Student's \& Teacher's } \\
\text { Questionnaires } \\
\text { (Total students' respondents) }\end{array}$ & Teachers' Responses & 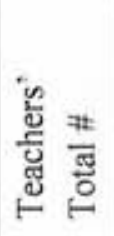 & 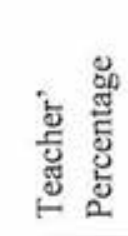 \\
\hline \multirow{8}{*}{$\begin{array}{l}\text { School's } \\
\text { communicat } \\
\text { ion of their } \\
\text { Discipline } \\
\text { Policies }\end{array}$} & \multirow{2}{*}{1} & $\begin{array}{l}\text { Checking whether teachers } \\
\text { received school's discipline } \\
\text { policies booklet }(94 \%)\end{array}$ & $\begin{array}{l}\text { Yes } \\
\text { No }\end{array}$ & $\begin{array}{l}17 \\
0\end{array}$ & $\begin{array}{l}94 \% \\
0 \%\end{array}$ \\
\hline & & When? $(94 \%)$ & $\begin{array}{l}\text { At the beginning of the year } \\
\text { In the middle of year } \\
\text { At the end of year }\end{array}$ & $\begin{array}{l}17 \\
0 \\
0\end{array}$ & $\begin{array}{l}94 \% \\
0 \% \\
0 \%\end{array}$ \\
\hline & 2 & $\begin{array}{l}\text { Communication of school's } \\
\text { policies }(100 \%)\end{array}$ & $\begin{array}{l}\text { A) School's Newsletters } \\
\text { B) Handbook to students } \\
\text { C) Handbook to parents } \\
\text { D) Students' meeting } \\
\text { E) Parents' meeting } \\
\text { F) others: } \\
\text { - B \& C } \\
\text { - C \& E } \\
\text { - A, C, \& E } \\
\text { - G) Not applicable }\end{array}$ & $\begin{array}{l}3 \\
5 \\
5 \\
0 \\
0 \\
4 \\
2 \\
1 \\
1 \\
1 \\
\end{array}$ & $\begin{array}{l}17 \% \\
28 \% \\
28 \% \\
0 \% \\
0 \% \\
22 \% \\
11 \% \\
6 \% \\
6 \% \\
6 \% \\
\end{array}$ \\
\hline & & $\begin{array}{l}\text { Whether teachers reminded } \\
\text { students of school's discipline } \\
\text { rules }(100 \%) \text {. }\end{array}$ & $\begin{array}{l}\text { Yes } \\
\text { No }\end{array}$ & $\begin{array}{l}17 \\
1\end{array}$ & $\begin{array}{l}94 \% \\
6 \%\end{array}$ \\
\hline & & When? $(94 \%)$ & $\begin{array}{l}\text { A) After the Winter Vacations } \\
\text { B) After the Summer Vacations }\end{array}$ & $\begin{array}{l}0 \\
5\end{array}$ & $\begin{array}{l}0 \% \\
28 \%\end{array}$ \\
\hline & 3 & & $\begin{array}{l}\text { C) After both Vacations } \\
\text { D) No } \\
\text { E) Others: } \\
\text { - At any urgent issue } \\
\text { - Throughout the year } \\
\text { - B \& whenever there is a need }\end{array}$ & $\begin{array}{l}4 \\
4 \\
1 \\
7 \\
4 \\
2 \\
1\end{array}$ & $\begin{array}{l}22 \% \\
6 \% \\
39 \% \\
22 \% \\
11 \% \\
6 \%\end{array}$ \\
\hline & 4 & $\begin{array}{l}\text { Considering revising of school's } \\
\text { discipline rules depending on } \\
\text { students' behavior }(94 \%)\end{array}$ & $\begin{array}{l}\text { A) always } \\
\text { B) generally } \\
\text { C) rarely }\end{array}$ & $\begin{array}{l}7 \\
8 \\
2\end{array}$ & $\begin{array}{l}39 \% \\
44 \% \\
11 \%\end{array}$ \\
\hline & 5 & $\begin{array}{l}\text { Teachers' provided students } \\
\text { training on school's discipline } \\
\text { rules }(94 \%)\end{array}$ & $\begin{array}{l}\text { Yes } \\
\text { No }\end{array}$ & $\begin{array}{l}11 \\
6\end{array}$ & $\begin{array}{l}61 \% \\
33 \%\end{array}$ \\
\hline
\end{tabular}




\begin{tabular}{|c|c|c|c|c|c|}
\hline \multirow[t]{2}{*}{$\begin{array}{l}\text { School's } \\
\text { communicat } \\
\text { ion of their } \\
\text { Discipline } \\
\text { Policies }\end{array}$} & & If yes, when? $(61 \%)$ & $\begin{array}{l}\text { Through the whole year } \\
\text { On daily basis } \\
\text { At the beginning of the year } \\
\text { Beginning of year \& after vacations } \\
\text { Every couple of days } \\
\text { At the beginning of the class } \\
\text { Whenever there is a } \\
\text { misbehave/violation } \\
\text { On different intervals in the year }\end{array}$ & $\begin{array}{l}1 \\
1 \\
1 \\
1 \\
1 \\
1 \\
4 \\
1\end{array}$ & $\begin{array}{l}6 \% \\
6 \% \\
6 \% \\
6 \% \\
6 \% \\
6 \% \\
22 \% \\
6 \%\end{array}$ \\
\hline & & For how many days $(33 \%)$ & $\begin{array}{l}- \\
2 \text { weeks } \\
- \\
1 \text { week } \\
\text { Depending on cases/need } \\
\text { Until they behave well }\end{array}$ & $\begin{array}{l}0 \\
0 \\
1 \\
0 \\
0 \\
1 \\
3 \\
1\end{array}$ & $\begin{array}{l}0 \% \\
0 \% \\
6 \% \\
0 \% \\
0 \% \\
6 \% \\
17 \% \\
6 \% \\
\end{array}$ \\
\hline \multirow{6}{*}{$\begin{array}{l}\text { Teachers' } \\
\text { Perceptions } \\
\text { of the } \\
\text { Discipline } \\
\text { Policies }\end{array}$} & \multirow[b]{2}{*}{6} & $\begin{array}{l}\text { Students clearly understand the } \\
\text { school's rules (100\%) }\end{array}$ & $\begin{array}{l}\text { Yes } \\
\text { No }\end{array}$ & $\begin{array}{l}13 \\
5\end{array}$ & $\begin{array}{l}72 \% \\
28 \%\end{array}$ \\
\hline & & If no, why? $(28 \%)$ & $\begin{array}{l}\text { Try to forget rules from time to time } \\
\text { Some rules need deep understanding } \\
\text { from students \& parents } \\
\text { Sts. Think it's out dated or not to be } \\
\text { applicable }\end{array}$ & $\begin{array}{l}3 \\
1 \\
1\end{array}$ & $\begin{array}{l}17 \% \\
6 \% \\
6 \%\end{array}$ \\
\hline & 9 & $\begin{array}{l}\text { Checking if school has too many } \\
\text { discipline rules ( } 94 \%)\end{array}$ & $\begin{array}{l}\text { Yes } \\
\text { No }\end{array}$ & $\begin{array}{l}2 \\
15\end{array}$ & $\begin{array}{l}11 \% \\
83 \%\end{array}$ \\
\hline & 12 & $\begin{array}{l}\text { Checking the level of students' } \\
\text { involvement in the development } \\
\text { of classroom rules }(94 \%)\end{array}$ & $\begin{array}{l}\text { A) generally involve students } \\
\text { B) sometimes involve students } \\
\text { C) seldom involve students } \\
\text { D) never involve students }\end{array}$ & $\begin{array}{l}2 \\
5 \\
2 \\
8\end{array}$ & $\begin{array}{l}11 \% \\
28 \% \\
11 \% \\
44 \%\end{array}$ \\
\hline & 13 & $\begin{array}{l}\text { Checking whether students make } \\
\text { their own decisions about } \\
\text { obeying rules }(100 \%)\end{array}$ & $\begin{array}{l}\text { A) very important } \\
\text { B) moderately important } \\
\text { C) not especially important }\end{array}$ & $\begin{array}{l}10 \\
7 \\
1\end{array}$ & $\begin{array}{l}56 \% \\
39 \% \\
6 \%\end{array}$ \\
\hline & 15 & $\begin{array}{l}\text { The most effective } \\
\text { implementation of school } \\
\text { discipline policy }(56 \%)\end{array}$ & $\begin{array}{l}\text { Order; Uniform; \& sport 's wear } \\
\text { Almost all discipline rules } \\
\text { Punishing impolite student by send } \\
\text { him home } \\
\text { Academically } \\
\text { Warnings } \\
\text { Deliberation at the end of year (firing } \\
\text { undisciplined students) }\end{array}$ & $\begin{array}{l}1 \\
4 \\
1 \\
1 \\
1 \\
1 \\
1\end{array}$ & $\begin{array}{l}6 \% \\
22 \% \\
6 \% \\
6 \% \\
6 \% \\
6 \%\end{array}$ \\
\hline
\end{tabular}




\begin{tabular}{|c|c|c|c|c|c|}
\hline & & & $\begin{array}{l}\text { Using the notes on the agenda on } \\
\text { misbehavior students }\end{array}$ & 1 & $6 \%$ \\
\hline \multirow{8}{*}{$\begin{array}{l}\text { Teachers' } \\
\text { Satisfaction } \\
\text { of the } \\
\text { implementat } \\
\text { ion of the } \\
\text { Discipline } \\
\text { Policies }\end{array}$} & 7 & $\begin{array}{l}\text { Teacher accepts the school's } \\
\text { philosophy regarding the } \\
\text { management of the students' } \\
\text { discipline }(100 \%)\end{array}$ & $\begin{array}{l}\text { A) fully approved } \\
\text { B) partially approved } \\
\text { C) minimally approved }\end{array}$ & $\begin{array}{l}10 \\
7 \\
1\end{array}$ & $\begin{array}{l}56 \% \\
39 \% \\
6 \%\end{array}$ \\
\hline & 18 & $\begin{array}{l}\text { Teachers' agreement with the } \\
\text { administrator's management } \\
(89 \%)\end{array}$ & $\begin{array}{l}\text { A) undivided } \\
\text { B) nearly undivided } \\
\text { C) split in their agreement }\end{array}$ & $\begin{array}{l}10 \\
5 \\
1\end{array}$ & $\begin{array}{l}56 \% \\
28 \% \\
6 \% \\
\end{array}$ \\
\hline & 8 & $\begin{array}{l}\text { Teachers support the school's } \\
\text { procedures concerning students' } \\
\text { discipline rules }(100 \%)\end{array}$ & $\begin{array}{l}\text { A) fully supported } \\
\text { B) partially supported } \\
\text { C) minimally supported }\end{array}$ & $\begin{array}{l}10 \\
6 \\
2 \\
\end{array}$ & $\begin{array}{l}56 \% \\
33 \% \\
11 \% \\
\end{array}$ \\
\hline & \multirow[t]{2}{*}{10} & $\begin{array}{l}\text { Teachers' involvement in the } \\
\text { development of school's } \\
\text { discipline policies (100\%) }\end{array}$ & $\begin{array}{l}\text { Yes } \\
\text { No }\end{array}$ & $\begin{array}{l}2 \\
16\end{array}$ & $\begin{array}{l}11 \% \\
89 \%\end{array}$ \\
\hline & & If yes, which rules? (6\%) & $\begin{array}{l}\text { Ethical relations between students \& } \\
\text { moral values }\end{array}$ & 1 & $6 \%$ \\
\hline & 11 & $\begin{array}{l}\text { Teachers' preference on being } \\
\text { involved in the decision on } \\
\text { school's discipline policies } \\
(94 \%)\end{array}$ & $\begin{array}{l}\text { A) more in teacher participation } \\
\text { B) less in teacher participation } \\
\text { C) no change in teacher participation }\end{array}$ & $\begin{array}{l}8 \\
1 \\
8\end{array}$ & $\begin{array}{l}44 \% \\
6 \% \\
44 \% \\
\end{array}$ \\
\hline & \multirow{2}{*}{14} & $\begin{array}{l}\text { Teachers' satisfaction with } \\
\text { school's discipline } \\
\text { implementation }(100 \%)\end{array}$ & $\begin{array}{l}\text { Yes } \\
\text { No }\end{array}$ & $\begin{array}{l}16 \\
2\end{array}$ & $\begin{array}{l}89 \% \\
11 \%\end{array}$ \\
\hline & & $\begin{array}{l}\text { If no, why? (100\%) (2 Ts. out of } \\
\text { 2) }\end{array}$ & $\begin{array}{l}\text { Stronger punishment are required } \\
\text { Certain cases are not fully considered } \\
\text { at proper time }\end{array}$ & $\begin{array}{l}1 \\
1\end{array}$ & $\begin{array}{l}50 \% \\
50 \%\end{array}$ \\
\hline $\begin{array}{l}\text { Problems in } \\
\text { Discipline }\end{array}$ & & & $\begin{array}{l}\text { - Not abiding by the dress code } \\
\text { - Standing with students more than }\end{array}$ & $\begin{array}{l}1 \\
1\end{array}$ & $\begin{array}{l}6 \% \\
6 \%\end{array}$ \\
\hline \multirow[t]{2}{*}{$\begin{array}{l}\text { Enforcemen } \\
t\end{array}$} & 16 & $\begin{array}{l}\text { The least effective } \\
\text { implementation of school } \\
\text { discipline policy ( } 44 \%) \\
\text { ( } 11 \% \text { or } 2 \text { teachers: None) } \\
\text { ( } 33 \% \text { or } 6 \text { teachers : Comment) }\end{array}$ & $\begin{array}{l}\text { teachers } \\
\text { - Disciplinary } \\
\text { - Suspending students for few days } \\
\text { - Political issues due to surrounding } \\
\text { political environment } \\
\text { - Monitoring students during recess; } \\
\text { coming \& leaving school delay entry to } \\
\text { class } \\
\text { - None }\end{array}$ & $\begin{array}{l}1 \\
1 \\
1 \\
1\end{array}$ & $\begin{array}{l}6 \% \\
6 \% \\
6 \% \\
6 \%\end{array}$ \\
\hline & 17 & $\begin{array}{l}\text { Students' indiscipline behavior } \\
\text { that is causing stress ( } 78 \% \text { ) }\end{array}$ & $\begin{array}{l}\text { Laughing for no reason } \\
\text { Being impolite / Disrespect } \\
\text { Delaying \& Disrupting class work } \\
\text { Disruptive behavior \& hyper behavior }\end{array}$ & $\begin{array}{l}1 \\
2 \\
1 \\
2\end{array}$ & $\begin{array}{l}6 \% \\
11 \% \\
6 \% \\
11 \%\end{array}$ \\
\hline
\end{tabular}




\begin{tabular}{|c|c|c|c|c|c|}
\hline \multirow[t]{6}{*}{$\begin{array}{l}\text { Problems in } \\
\text { Discipline } \\
\text { Enforcemen } \\
t\end{array}$} & & & $\begin{array}{l}\text { (needs more effort especially small } \\
\text { students) } \\
\text { Hyperactivity; \& cheating } \\
\text { Talking in class during explanation } \\
\text { Political issues since politics is } \\
\text { forbidden. } \\
\text { Administration does not notice } \\
\text { students who abide by regulations. } \\
\text { Waste time during lesson; } \\
\text { talkativeness; cheating; carelessness; } \\
\text { taking a lot of permissions to go out; } \\
\text { not following instructions to do H.W }\end{array}$ & $\begin{array}{l}1 \\
4 \\
1 \\
1\end{array}$ & $\begin{array}{l}6 \% \\
22 \% \\
6 \% \\
6 \% \\
6 \%\end{array}$ \\
\hline & 19 & $\begin{array}{l}\text { Checking whether sch. } \\
\text { Discipline problems are } \uparrow \text { or } \downarrow \\
(89 \%)\end{array}$ & $\begin{array}{l}\text { A) have decreased } \\
\text { B) have increased } \\
\text { C) are about the same as }\end{array}$ & $\begin{array}{l}7 \\
3 \\
6 \\
\end{array}$ & $\begin{array}{l}39 \% \\
17 \% \\
33 \% \\
\end{array}$ \\
\hline & 20 & $\begin{array}{l}\text { Effect of school's discipline } \\
\text { policies on students' tardiness or } \\
\text { class delay }(67 \%)\end{array}$ & $\begin{array}{l}\text { A) more } \\
\text { B) less } \\
\text { C) the same number of class delay }\end{array}$ & $\begin{array}{l}1 \\
5 \\
6\end{array}$ & $\begin{array}{l}6 \% \\
28 \% \\
33 \%\end{array}$ \\
\hline & 21 & $\begin{array}{l}\text { Effect of school's discipline } \\
\text { policies on students' class cuts } \\
(72 \%)\end{array}$ & $\begin{array}{l}\text { A) more } \\
\text { B) less } \\
\text { C) the same number of class cuts }\end{array}$ & $\begin{array}{l}1 \\
6 \\
6\end{array}$ & $\begin{array}{l}6 \% \\
33 \% \\
33 \% \\
\end{array}$ \\
\hline & 22 & $\begin{array}{l}\text { School is or isn't facing } \\
\text { students' discipline problems } \\
(100 \%)\end{array}$ & $\begin{array}{l}\text { A) a major } \\
\text { B) a minor } \\
\text { C) not a problem }\end{array}$ & $\begin{array}{l}1 \\
10 \\
7\end{array}$ & $\begin{array}{l}6 \% \\
56 \% \\
39 \% \\
\end{array}$ \\
\hline & 24 & $\begin{array}{l}\text { Time wasted by teachers on the } \\
\text { enforcement of school's } \\
\text { discipline rules (100\%) }\end{array}$ & $\begin{array}{l}\text { A) less than } 10 \% \\
\text { B) } 10 \% \\
\text { C) } 20 \% \\
\text { D) More than } 20 \% \text { of class time. }\end{array}$ & $\begin{array}{l}15 \\
2 \\
0 \\
1\end{array}$ & $\begin{array}{l}83 \% \\
11 \% \\
0 \% \\
6 \%\end{array}$ \\
\hline \multirow{2}{*}{$\begin{array}{l}\text { Teachers' } \\
\text { Involvement } \\
\text { in Students' } \\
\text { Behavioral } \\
\text { Record }\end{array}$} & & $\begin{array}{l}\text { Being involved in providing any } \\
\text { Intermediate student with oral }\end{array}$ & $\begin{array}{l}\text { Yes } \\
\text { No }\end{array}$ & $\begin{array}{l}10 \\
8\end{array}$ & $\begin{array}{l}56 \% \\
44 \%\end{array}$ \\
\hline & 25 & $\begin{array}{l}\text { warning ( } 100 \%) \\
\text { How many times? ( } 44 \% \text { or } 8 \\
\text { teachers) }\end{array}$ & $\begin{array}{l}3 \text { times } \\
2 \text { times } \\
1 \text { time } \\
\text { Few times } \\
\text { Several times } \\
\text { No comment } \\
3 \text { times: Bad behavior } \\
2 \text { times: } \\
\text {-Talkativeness } \\
\text { - Impatience to tolerate bad behavior } \\
\text {-Lack of attention }\end{array}$ & $\begin{array}{l}1 \\
3 \\
1 \\
1 \\
2 \\
2\end{array}$ & $\begin{array}{l}6 \% \\
11 \% \\
6 \% \\
6 \% \\
11 \% \\
11 \% \\
6 \% \\
\\
6 \% \\
6 \% \\
6\end{array}$ \\
\hline
\end{tabular}




\begin{tabular}{|c|c|c|c|c|c|}
\hline \multirow{4}{*}{$\begin{array}{l}\text { Teachers' } \\
\text { Involvement } \\
\text { in Students' } \\
\text { Behavioral } \\
\text { Record }\end{array}$} & & $\begin{array}{l}\text { Lack of attention: } 1+1+>4=>6 \\
\text { times } \\
\text { Delay: }>4 \text { times } \\
\text { Lack of sportswear: }>4 \text { times } \\
\text { Ethical; moral, \& social: }>3 \\
\text { times } \\
\text { Talkativeness: } 1+1=2 \text { times }\end{array}$ & $\begin{array}{l}1 \text { time: Talking \& lack of attention } \\
\text { Few times }(>3) \text { : Ethical; moral; \& } \\
\text { social } \\
\text { Several times (more than } 4 \text { times) } \\
\text {-Delay; \& lack of sportswear } \\
\text {-Bad behavior; \& lack of attention } \\
\text { No comment: } \\
\text {-Not following instructions }\end{array}$ & $\begin{array}{l}1 \\
1 \\
1 \\
1\end{array}$ & $\begin{array}{l}6 \% \\
6 \% \\
6 \% \\
6 \% \\
\end{array}$ \\
\hline & 26 & $\begin{array}{l}\text { Being involved in providing any } \\
\text { Intermediate student with minor } \\
\text { written warning (100\%) } \\
\text { How many times? }(28 \%)\end{array}$ & $\begin{array}{l}\text { Yes } \\
\text { No } \\
3 \text { times } \\
2 \text { times } \\
1 \text { time } \\
\text { Few times } \\
3 \text { times: Misbehavior; \& laughing } \\
2 \text { times: } \\
\text { Misbehavior; \& laughing } \\
\text { No comment } \\
1 \text { time: talking \& lack of attention } \\
\text { Few times(>3): Not doing H.W, or } \\
\text { studying }\end{array}$ & $\begin{array}{l}1 \\
2 \\
1 \\
1 \\
1 \\
1 \\
1 \\
1 \\
1\end{array}$ & $\begin{array}{l}28 \% \\
72 \% \\
\\
6 \% \\
11 \% \\
6 \% \\
6 \% \\
6 \% \\
6 \% \\
6 \% \\
6 \% \\
6 \%\end{array}$ \\
\hline & & $\begin{array}{l}\text { Being involved in providing any } \\
\text { Intermediate student with major } \\
\text { written warning }(100 \%)\end{array}$ & $\begin{array}{l}\text { Yes } \\
\text { No } \\
2 \text { times }\end{array}$ & $\begin{array}{l}3 \\
15 \\
2\end{array}$ & $\begin{array}{l}17 \% \\
83 \% \\
11 \%\end{array}$ \\
\hline & 27 & $\begin{array}{l}\text { How many times? }(17 \%) \\
\text { Main reasons ( } 11 \% \text { or } 2 \\
\text { teachers) } \\
\text { Laughing \& talking: } 2 \text { times } \\
\text { No hope to change his bad } \\
\text { behavior: } 1 \text { time }\end{array}$ & $\begin{array}{l}1 \text { time } \\
2 \text { times: } \\
\text { Misbehaving in class (laughing, \& } \\
\text { talking) } \\
\text { No comment } \\
1 \text { time: No hope to change his bad } \\
\text { behavior }\end{array}$ & $\begin{array}{l}1 \\
1 \\
1\end{array}$ & $\begin{array}{l}6 \% \\
6 \% \\
6 \%\end{array}$ \\
\hline $\begin{array}{l}\text { Bullying } \\
\text { Problems }\end{array}$ & 28 & $\begin{array}{l}\text { Do you have bullies in your } \\
\text { class? }(94 \%)\end{array}$ & $\begin{array}{l}\text { Yes } \\
\text { No }\end{array}$ & $\begin{array}{l}5 \\
12\end{array}$ & $\begin{array}{l}28 \% \\
67 \%\end{array}$ \\
\hline
\end{tabular}




\begin{tabular}{|c|c|c|c|c|c|}
\hline & & $\begin{array}{l}\text { Did students contact you in case } \\
\text { of being bullied? }(100 \%)\end{array}$ & \begin{tabular}{|l|} 
Yes \\
No
\end{tabular} & $\begin{array}{l}7 \\
11\end{array}$ & $\begin{array}{l}39 \% \\
61 \%\end{array}$ \\
\hline & 29 & $\begin{array}{l}\text { If yes, how did you treat bully \& } \\
\text { bullied? }(28 \%)\end{array}$ & $\begin{array}{l}\text { *Trying to ease their tension \& make } \\
\text { peace between them. } \\
\text { *Investigating; comforting \& helping } \\
\text { the bullied; warning the bully to } \\
\text { realize his mistake; if cases are } \\
\text { repeated, I inform Administration. } \\
\text { *Keep bully busy( erasing board, } \\
\text { distributing papers); \& to raise self- } \\
\text { esteem of bullied by encouraging } \\
\text { them \& allow them to feel safe \& not } \\
\text { alone } \\
\text { *Students could solve their problems; } \\
\text { but if I interfere, I give students small } \\
\text { moral lesson. In case of physical } \\
\text { bullying, I inform administration }\end{array}$ & $\begin{array}{l}1 \\
2\end{array}$ & $\begin{array}{l}6 \% \\
11 \% \\
6 \%\end{array}$ \\
\hline & & $\begin{array}{l}\text { Whether school cared for the } \\
\text { safety of students from bullies } \\
(100 \%)\end{array}$ & $\begin{array}{l}\text { Yes } \\
\text { No }\end{array}$ & $\begin{array}{l}18 \\
0\end{array}$ & $\begin{array}{l}100 \% \\
0 \%\end{array}$ \\
\hline & 30 & How do you know? $(78 \%)$ & $\begin{array}{l}\text { "Though urgent meeting with } \\
\text { Administrator to discuss students' } \\
\text { cases; \& through classes } \\
\text { deliberations.... } \\
\text { "Bullies are punished through written } \\
\text { \& oral warnings } \\
\text { "Based on the teachers' remarks } \\
\text { "From administration supports } \\
\text { "From the school's rules } \\
\text { "From the overall school environment }\end{array}$ & $\begin{array}{l}3 \\
1 \\
1 \\
1 \\
1\end{array}$ & $\begin{array}{l}17 \% \\
6 \% \\
6 \% \\
6 \% \\
6 \% \\
\end{array}$ \\
\hline $\begin{array}{l}\text { Modificatio } \\
\text { ns Needed }\end{array}$ & 31 & $\begin{array}{l}\text { School areas that needed more } \\
\text { surveillance to control students' } \\
\text { bullying }(100 \%)\end{array}$ & $\begin{array}{l}\text { A) Hallways } \\
\text { B) Playground } \\
\text { C) Bathrooms } \\
\text { D) All of the three areas } \\
\text { E) Other: D \& classrooms }\end{array}$ & $\begin{array}{l}0 \\
3 \\
1 \\
13 \\
1\end{array}$ & \begin{tabular}{|l|}
$0 \%$ \\
$17 \%$ \\
$6 \%$ \\
$72 \%$ \\
$6 \%$ \\
\end{tabular} \\
\hline & 32 & $\begin{array}{l}\text { Safety procedures that should be } \\
\text { used by school }(94 \%)\end{array}$ & $\begin{array}{l}\text { A) Adult hall monitors } \\
\text { B) police guard } \\
\text { C) Metal detectors } \\
\text { D) Cameras } \\
\text { E) None } \\
\text { F) Other: A \& D }\end{array}$ & $\begin{array}{l}9 \\
0 \\
0 \\
2 \\
4 \\
2\end{array}$ & $\begin{array}{l}50 \% \\
0 \% \\
0 \% \\
11 \% \\
22 \% \\
11 \%\end{array}$ \\
\hline
\end{tabular}




\begin{tabular}{|c|c|c|c|c|c|}
\hline & 23 & $\begin{array}{l}\text { Checking whether school's } \\
\text { discipline policies need change } \\
(100 \%)\end{array}$ & $\begin{array}{l}\text { A) sufficient \& appropriate \& need no } \\
\text { change } \\
\text { B) in need of some minor change } \\
\text { C) in need of a major overhaul change }\end{array}$ & $\begin{array}{l}6 \\
10 \\
2\end{array}$ & $\begin{array}{l}33 \% \\
56 \% \\
11 \%\end{array}$ \\
\hline & 33 & $\begin{array}{l}\text { Discipline rules that should be } \\
\text { added }(100 \%)\end{array}$ & $\begin{array}{l}\text { No need } \\
\text { Program of punishment on Saturday's } \\
\text { Detention rule }\end{array}$ & $\begin{array}{l}16 \\
1 \\
1\end{array}$ & $\begin{array}{l}89 \% \\
6 \% \\
6 \% \\
\end{array}$ \\
\hline \multirow{2}{*}{$\begin{array}{l}\text { Teachers' } \\
\text { History }\end{array}$} & 34 & $\begin{array}{l}\text { Years of teaching in school } \\
(100 \%)\end{array}$ & $\begin{array}{l}\text { A) one } \\
\text { B) two } \\
\text { C) three to five } \\
\text { D) six to ten } \\
\text { E) more than ten years }\end{array}$ & $\begin{array}{l}1 \\
2 \\
0 \\
1 \\
14\end{array}$ & $\begin{array}{l}6 \% \\
11 \% \\
0 \% \\
6 \% \\
78 \% \\
\end{array}$ \\
\hline & 35 & Years of teaching $(100 \%)$ & $\begin{array}{l}\text { A) One to two } \\
\text { B) Three to five } \\
\text { C) Six to ten } \\
\text { D) More than ten years }\end{array}$ & $\begin{array}{l}1 \\
0 \\
2 \\
15\end{array}$ & $\begin{array}{l}6 \% \\
0 \% \\
11 \% \\
83 \%\end{array}$ \\
\hline
\end{tabular}

N.B: Green Cells include the Alternative Concepts in the Teachers' Questionnaire White Cells include the Similar Concepts in the Teachers' \& Students' Questionnaires 
Appendix $N$

Table Presenting the Data from the Teachers' Questionnaire: (Second Part)

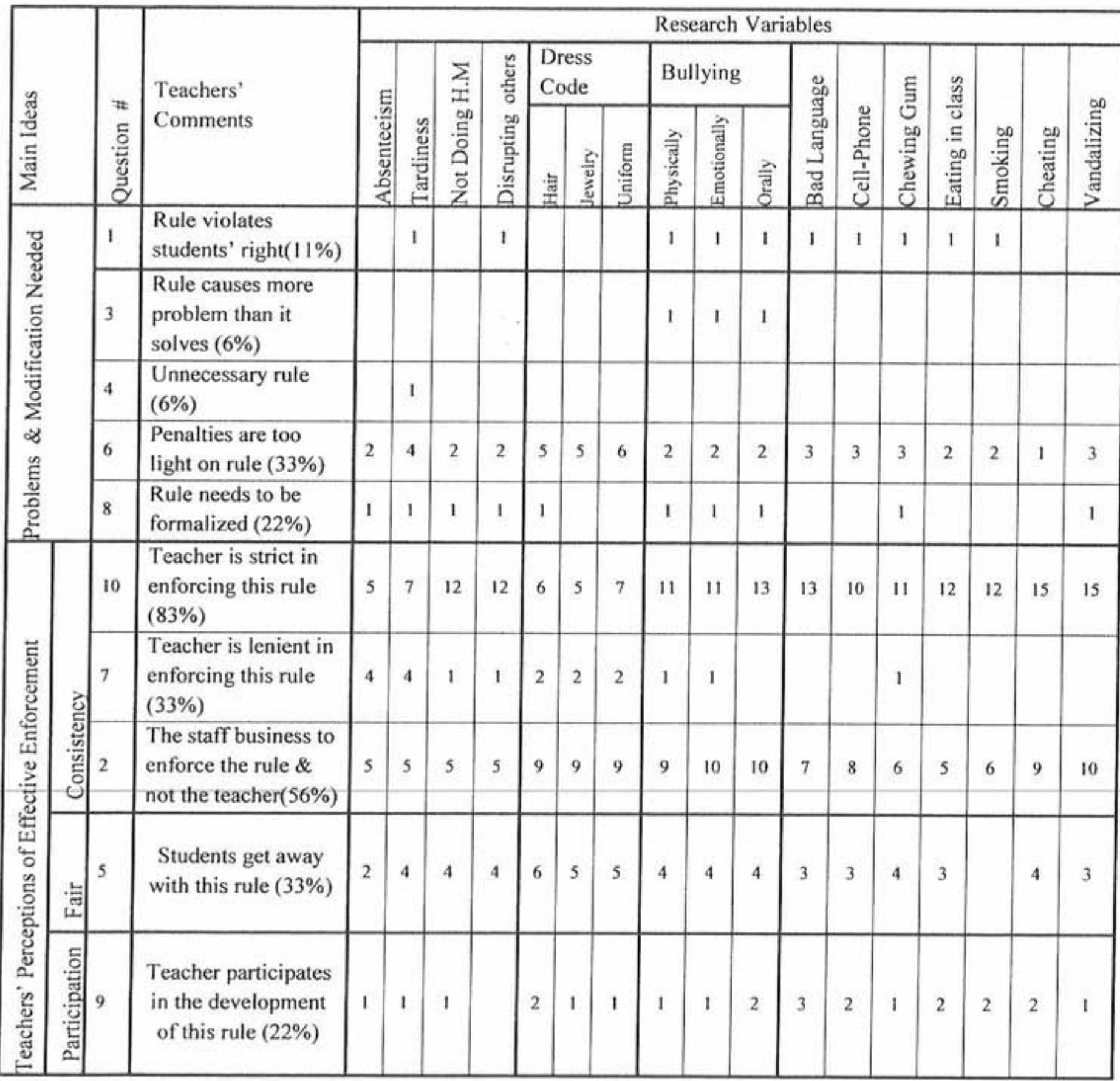


Appendix $O$

Table Presenting the Percentages of Data from the Teachers' Questionnaire: (Second Part)

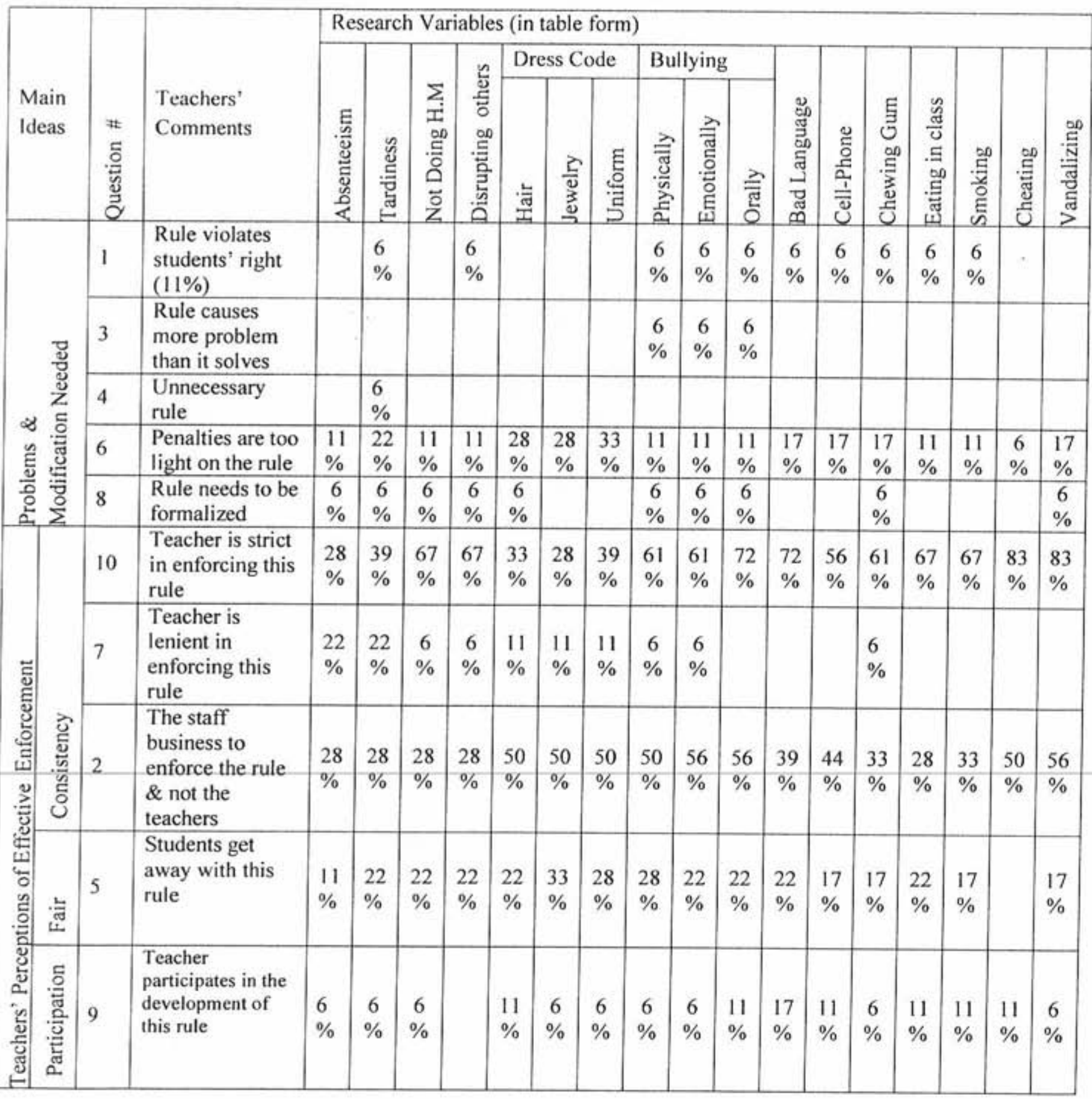




\section{Appendix $P$}

Tables Presenting Observation Data

\begin{tabular}{|c|c|c|c|c|c|c|c|c|}
\hline $\begin{array}{l}\text { Table P1. } \\
\text { Bullying Cases in Playground }\end{array}$ & & & & & & & & \\
\hline \multirow{3}{*}{$\begin{array}{l}\text { Bullying cases } \\
\text { Physical bullying: }\end{array}$} & \multirow{2}{*}{\multicolumn{2}{|c|}{$\begin{array}{l}\text { Students' } \\
\text { Violations } \\
\end{array}$}} & \multirow{2}{*}{\multicolumn{2}{|c|}{$\begin{array}{l}\text { Violations } \\
\text { Percentages }\end{array}$}} & \multicolumn{2}{|c|}{$\begin{array}{l}\text { School's } \\
\text { Reactions }\end{array}$} & \multirow{3}{*}{$\begin{array}{l}\text { School's } \\
\text { Reactions }\end{array}$} & \multirow{2}{*}{$\begin{array}{l}\text { Percentages } \\
\text { of Reactions }\end{array}$} \\
\hline & & & & & Male & Female & & \\
\hline & & & & & & & & \\
\hline Pushing near canteen & 60 & 15 & $49 \%$ & $12 \%$ & 0 & 0 & 0 & $0 \%$ \\
\hline Kicking \& slapping & 8 & 0 & $6 \%$ & & 0 & 0 & 0 & $0 \%$ \\
\hline Throwing water & 2 & 0 & $1.6 \%$ & & 0 & 0 & 0 & $0 \%$ \\
\hline Total & 70 & 15 & $54 \%$ & $12 \%$ & 0 & 0 & 0 & $0 \%$ \\
\hline Total physical bullying & & 5 & & $6 \%$ & & & & \\
\hline Emotional bullying & 2 & 0 & $1.6 \%$ & & 0 & 0 & 0 & $0 \%$ \\
\hline Verbal bullying & 41 & 0 & $32 \%$ & & 1 & & 1 & $2.4 \%$ \\
\hline Total & 113 & 15 & $88 \%$ & $12 \%$ & 1 & 0 & 1 & $0.8 \%$ \\
\hline Total bullying violations & & & & & & & & \\
\hline
\end{tabular}

Note. The percentages of the school's reactions to bullying are calculated by dividing the total school's reactions on specific type of bullying by the total bullying violations. 
Table P2.

Vandalism Cases in Playground

\begin{tabular}{|c|c|c|c|c|c|c|c|c|c|c|c|}
\hline \multirow[t]{2}{*}{ Vandalism Cases } & \multirow[t]{2}{*}{$\begin{array}{c}\text { Students' } \\
\text { Grade }\end{array}$} & \multicolumn{2}{|c|}{$\begin{array}{l}\text { Students' } \\
\text { Violations }\end{array}$} & \multirow[t]{2}{*}{$\begin{array}{c}\text { Total } \\
\text { Violations }\end{array}$} & \multicolumn{3}{|c|}{$\begin{array}{l}\text { Violations } \\
\text { Percentages }\end{array}$} & \multicolumn{3}{|c|}{$\begin{array}{l}\text { Supervisor's } \\
\text { Reactions }\end{array}$} & \multirow[t]{2}{*}{$\begin{array}{l}\text { Reactio } \\
\text { Percent: }\end{array}$} \\
\hline & & $\bar{\sigma}$ & 우 & & 8 & q & $\underline{\text { Total }}$ & $\delta$ & P & Total & \\
\hline \multirow{4}{*}{$\begin{array}{l}\text { Tearing out } \\
\text { leaves of trees } \\
(30 \%)\end{array}$} & Seventh & 20 & 4 & 24 & $17 \%$ & $4 \%$ & $21 \%$ & 1 & 0 & 0 & $3 \%$ \\
\hline & Eighth & 10 & 0 & 10 & $9 \%$ & $0 \%$ & $9 \%$ & 0 & 0 & 0 & $0 \%$ \\
\hline & & $\ldots$ & $\cdots$ & -- & $\ldots$ & $\cdots$ & $\ldots$ & $\cdots$ & $\cdots$ & -- & - \\
\hline & Total & 30 & 4 & 34 & $26 \%$ & $4 \%$ & $30 \%$ & 1 & 0 & 1 & $3 \%$ \\
\hline \multirow{4}{*}{$\begin{array}{l}\text { Shacking roughly } \\
\text { the garden weir } \\
(13 \%)\end{array}$} & Seventh & 10 & 0 & 10 & $9 \%$ & $0 \%$ & $9 \%$ & 0 & 0 & 0 & $0 \%$ \\
\hline & Eighth & 5 & 0 & 5 & $4 \%$ & $0 \%$ & $4 \%$ & 0 & 0 & 0 & $0 \%$ \\
\hline & & 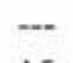 & $\cdots$ & -nen & --- & $\cdots$ & - & -- & $\ldots$ & $-\cdots$ & --..- \\
\hline & Total & 15 & 0 & 15 & $13 \%$ & $0 \%$ & $13 \%$ & 0 & 0 & 0 & $0 \%$ \\
\hline $\begin{array}{l}\text { Damaging the } \\
\text { garden weir ( } 1 \%)\end{array}$ & Eighth & 1 & 0 & 1 & $1 \%$ & $0 \%$ & $1 \%$ & 1 & 0 & 1 & $100 \%$ \\
\hline $\begin{array}{l}\text { Standing on } \\
\text { classroom chairs } \\
(2 \%)\end{array}$ & Ninth & 2 & 0 & 2 & $2 \%$ & $0 \%$ & $2 \%$ & 0 & 0 & 0 & $0 \%$ \\
\hline Littering in & Seventh & 19 & 6 & 25 & $17 \%$ & $5 \%$ & $22 \%$ & 0 & 0 & 0 & $0 \%$ \\
\hline playground & Eighth & 12 & 5 & 17 & $11 \%$ & $4 \%$ & $15 \%$ & 0 & 0 & 0 & $0 \%$ \\
\hline \multirow[t]{2}{*}{$(54 \%)$} & Ninth & 15 & 4 & 19 & $13 \%$ & $4 \%$ & $17 \%$ & 0 & 0 & 0 & $0 \%$ \\
\hline & Total & 46 & 15 & 61 & $41 \%$ & $13 \%$ & $54 \%$ & 0 & 0 & 0 & $0 \%$ \\
\hline Total Vandalism & Seventh & 49 & 10 & 59 & $43 \%$ & $9 \%$ & $52 \%$ & 1 & 0 & 1 & $1 \%$ \\
\hline \multirow[t]{2}{*}{ Violations } & Eighth & 28 & 5 & 33 & $25 \%$ & $4 \%$ & $29 \%$ & 1 & 0 & 1 & $1 \%$ \\
\hline & Ninth & 17 & 4 & 21 & $15 \%$ & $4 \%$ & $19 \%$ & 0 & 0 & 0 & $0 \%$ \\
\hline \multicolumn{2}{|c|}{ General Total Violations } & 94 & 19 & 113 & $83 \%$ & $17 \%$ & $100 \%$ & 2 & 0 & 2 & $2 \%$ \\
\hline
\end{tabular}

Note. $\delta=$ Male; $Q=$ Female. Reaction percentages are calculated by dividing the total supervisor's reactions by the total violations. 


\begin{tabular}{|c|c|c|c|c|c|c|}
\hline Plavground Data & & & & & & \\
\hline & $\begin{array}{c}\text { Total } \\
\text { Violations }\end{array}$ & $\underline{\text { Students' }}$ & Violations & $\begin{array}{c}\text { Frequency of } \\
\text { Personnel's } \\
\text { Reactions }\end{array}$ & $\begin{array}{c}\text { Percentage of } \\
\text { Personnel's } \\
\text { Reactions }\end{array}$ & $\begin{array}{c}\text { Evaluation of } \\
\text { Discipline } \\
\text { Enforcement }\end{array}$ \\
\hline & & Male & Female & & & \\
\hline Disruption & 3 & 3 & 0 & 3 & $100 \%$ & 1 \\
\hline Jewelry & 11 & 6 & 5 & 1 & $9.1 \%$ & 4 \\
\hline Verbal bullying & 41 & 41 & 0 & 1 & $2.4 \%$ & 4 \\
\hline Vandalism & 113 & 94 & 19. & 2 & $1.8 \%$ & 4 \\
\hline Uniform & 3 & 2 & 1 & 0 & $0 \%$ & 5 \\
\hline Hair & 3 & 3 & 0 & 0 & $0 \%$ & 5 \\
\hline Emotional Bullying & 2 & 2 & 0 & 0 & $0 \%$ & 5 \\
\hline Physical bullying & 85 & 70 & 15 & 0 & $0 \%$ & 5 \\
\hline Bad Language & 6 & 6 & 0 & 0 & $0 \%$ & 5 \\
\hline Total & 267 & 227 & 40 & 7 & $2.6 \%$ & 4 \\
\hline
\end{tabular}

Note. The percentage of the school's reactions is calculated by dividing the frequency of the school's reactions by the frequency of the students' violations. (Evaluation Criteria: 1= Highly Enforced; 2 =Quite Enforced; 3 = Moderately Enforced; 4 = Slightly Enforced; $5=$ Not Enforced). 


\section{Table P4}

Evaluation of Corridors and Stairs Rules Enforcement

\begin{tabular}{|c|c|c|c|c|c|c|c|c|c|}
\hline $\begin{array}{l}\text { Violation } \\
\text { cases }\end{array}$ & $\begin{array}{r}\text { Freq } \\
\text { Stt } \\
\text { Vic } \\
\end{array}$ & $\begin{array}{l}\text { ency of } \\
\text { lents' } \\
\text { ations }\end{array}$ & $\begin{array}{c}\text { Frequency } \\
\text { of total } \\
\text { Students' } \\
\text { Violations }\end{array}$ & $\begin{array}{l}\text { Freq } \\
\text { Sup } \\
\text { Re }\end{array}$ & $\begin{array}{l}\text { ency of } \\
\text { visor's } \\
\text { ctions }\end{array}$ & $\begin{array}{c}\text { Frequency } \\
\text { of total } \\
\text { Supervisor } \\
\text { Reactions }\end{array}$ & $\begin{array}{l}\text { Percentage } \\
\text { of Reaction }\end{array}$ & $\begin{array}{c}\text { Referral } \\
\text { Discipline } \\
\text { Record }\end{array}$ & Evaluation \\
\hline Physical & Male & $\underline{\text { Female }}$ & & Male & $\underline{\text { Female }}$ & & & & \\
\hline bullying & 2 & 0 & 2 & 1 & 0 & 1 & $50 \%$ & 0 & 5 \\
\hline Disrupting & 1 & 1 & 2 & 1 & 1 & 2 & $100 \%$ & 0 & 5 \\
\hline others & $\cdots$ & ..... & 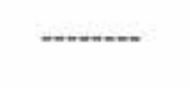 & -..- & -... & -..... & ב......... & - & $+\cdots$ \\
\hline Total & 3 & 1 & 4 & 2 & 1 & 3 & $75 \%$ & 0 & 5 \\
\hline
\end{tabular}

Note. The percentages of reactions are calculated by dividing frequency of the total school' reaction by the frequency of the total students' violations. (Evaluation Criteria: I= Highly Enforced; 2 = Quite Enforced; 3 = Moderately Enforced; $4=$ Slightly Enforced; $5=$ Not Enforced). 


\begin{tabular}{|c|c|c|c|c|c|c|c|c|c|}
\hline \multicolumn{10}{|c|}{$\begin{array}{l}\text { Table P5. } \\
\text { Classroom Disruption Violations of Seventh Graders }\end{array}$} \\
\hline $\begin{array}{l}\text { Seventh } \\
\text { Grade }\end{array}$ & $\begin{array}{l}\text { Disr } \\
\text { Viol } \\
\end{array}$ & $\begin{array}{l}\text { pting } \\
\text { tions }\end{array}$ & $\begin{array}{r}\mathrm{T} \\
\text { Stur } \\
\text { Viol } \\
\end{array}$ & $\begin{array}{l}\text { otal } \\
\text { dents' } \\
\text { lations }\end{array}$ & $\begin{array}{l}\text { Teachers } \\
\text { Reaction to } \\
\text { use CRM }\end{array}$ & $\begin{array}{l}\text { Percentage } \\
\text { of using } \\
\text { CRM }\end{array}$ & $\begin{array}{l}\text { Teachers' } \\
\text { Reporting } \\
\text { on } \\
\text { Disruption }\end{array}$ & $\begin{array}{l}\text { Disrupting } \\
\text { Referrals }\end{array}$ & $\begin{array}{c}\% \text { of School's } \\
\text { Reactions to } \\
\text { Teachers' } \\
\text { Reporting }\end{array}$ \\
\hline Materials & 8 & 오 & $\underline{F}$ & $\%$ & & & & & \\
\hline English & 20 & 11 & 31 & $36 \%$ & 13 & $42 \%$ & 0 & 0 & $0 \%$ \\
\hline $\begin{array}{l}\text { Geography } \\
\text { History }\end{array}$ & 15 & 7 & 22 & $26 \%$ & 17 & $77 \%$ & 1 & 1 & $100 \%$ \\
\hline $\begin{array}{l}\text { Social } \\
\text { Studies }\end{array}$ & 5 & 5 & 10 & $12 \%$ & 7 & $70 \%$ & 0 & 0 & $0 \%$ \\
\hline Physics & 4 & 4 & 8 & $9 \%$ & 0 & $0 \%$ & 0 & 0 & $0 \%$ \\
\hline Math & 5 & & 5 & $6 \%$ & 5 & $100 \%$ & 0 & 0 & $0 \%$ \\
\hline Science & 1 & 3 & 4 & $5 \%$ & 4 & $100 \%$ & 0 & 0 & $0 \%$ \\
\hline Arabic & 3 & 0 & 3 & $4 \%$ & 3 & $100 \%$ & 3 & 3 & $100 \%$ \\
\hline French & 2 & & 2 & $2 \%$ & 2 & $100 \%$ & 0 & 0 & $0 \%$ \\
\hline Total & 55 & 30 & 85 & $100 \%$ & 51 & $60 \%$ & 4 & 4 & $100 \%$ \\
\hline Percentage & Teacl & ers' re & orting & & & & $4.7 \%$ & & \\
\hline
\end{tabular}

Note. $\mathrm{CRM}=$ Classroom Management; $\delta=$ Male; $q=$ Female; $\mathrm{F}=$ frequency; $\%=$ Percentage; the percentage of using CRM is calculated by dividing frequency of the teacher's reactions to use CRM by the frequency of the students' violations. The percentage of the school's reactions to disruption is calculated by dividing the numbers of referrals by the frequency of teachers' reporting. The percentage of teachers' reporting is calculated by dividing the frequency of teachers' reporting by the frequency of students' violations. 
Table P6.

Classroom Disruption Violations of Eighth Graders

\begin{tabular}{|c|c|c|c|c|c|c|c|c|c|}
\hline Eighth Grade & $\begin{array}{l}\text { Disri } \\
\text { Viol }\end{array}$ & $\begin{array}{l}\text { tion } \\
\text { ions }\end{array}$ & & $\begin{array}{l}\text { otal } \\
\text { dents' } \\
\text { ations }\end{array}$ & $\begin{array}{c}\text { Frequency } \\
\text { of using } \\
\text { CRM }\end{array}$ & $\begin{array}{c}\text { Percentage } \\
\text { of using } \\
\text { CRM }\end{array}$ & $\begin{array}{l}\text { Teachers' } \\
\text { Reporting }\end{array}$ & $\begin{array}{c}\text { Disrupting } \\
\underline{\text { Referrals }}\end{array}$ & $\begin{array}{l}\text { Percentage } \\
\text { of School's } \\
\text { Reactions }\end{array}$ \\
\hline Materials & 3 & 오 & $\underline{F}$ & $\%$ & & & & & \\
\hline Social Studies & 4 & 15 & 19 & $33 \%$ & 8 & $42 \%$ & 0 & 0 & 0 \\
\hline Geography & 6 & 3 & 9 & $16 \%$ & 6 & $67 \%$ & 0 & 0 & 0 \\
\hline French & 4 & 4 & 8 & $14 \%$ & 2 & $25 \%$ & 0 & 0 & 0 \\
\hline Physics & 2 & 5 & 7 & $12 \%$ & 4 & $57 \%$ & 0 & 0 & 0 \\
\hline English & 5 & 1 & 6 & $10 \%$ & 4 & $67 \%$ & 0 & 0 & 0 \\
\hline Computer & 4 & 1 & 5 & $9 \%$ & 2 & $40 \%$ & 0 & 0 & 0 \\
\hline Math & 1 & 1 & 2 & $3 \%$ & 2 & $100 \%$ & 0 & 0 & 0 \\
\hline \multirow[t]{2}{*}{ History } & 1 & & 1 & $1 \%$ & 1 & $100 \%$ & 0 & 0 & 0 \\
\hline & $\cdots$ & $\cdots$ & - & $\cdots$ & $\cdots$ & $+\cdots$ & $\cdots$ & $\cdots$ & - \\
\hline Total & 27 & 30 & 57 & $100 \%$ & 29 & $51 \%$ & 0 & 0 & 0 \\
\hline
\end{tabular}

Note. $\mathrm{CRM}=\mathrm{Classroom}$ Management; $\delta=$ Male; $\phi=$ Female; $\mathrm{F}=$ Frequency; $\%=$ Percentage; the percentage of using CRM is calculated by dividing frequency of the teacher's reactions to use CRM by the frequency of the students' violations. The percentage of the school's reactions to disruption is calculated by dividing the numbers of referrals by the frequency of teachers' reporting. The percentage of teachers' reporting is calculated by dividing the frequency of teachers' reporting by the frequency of students' violations. 


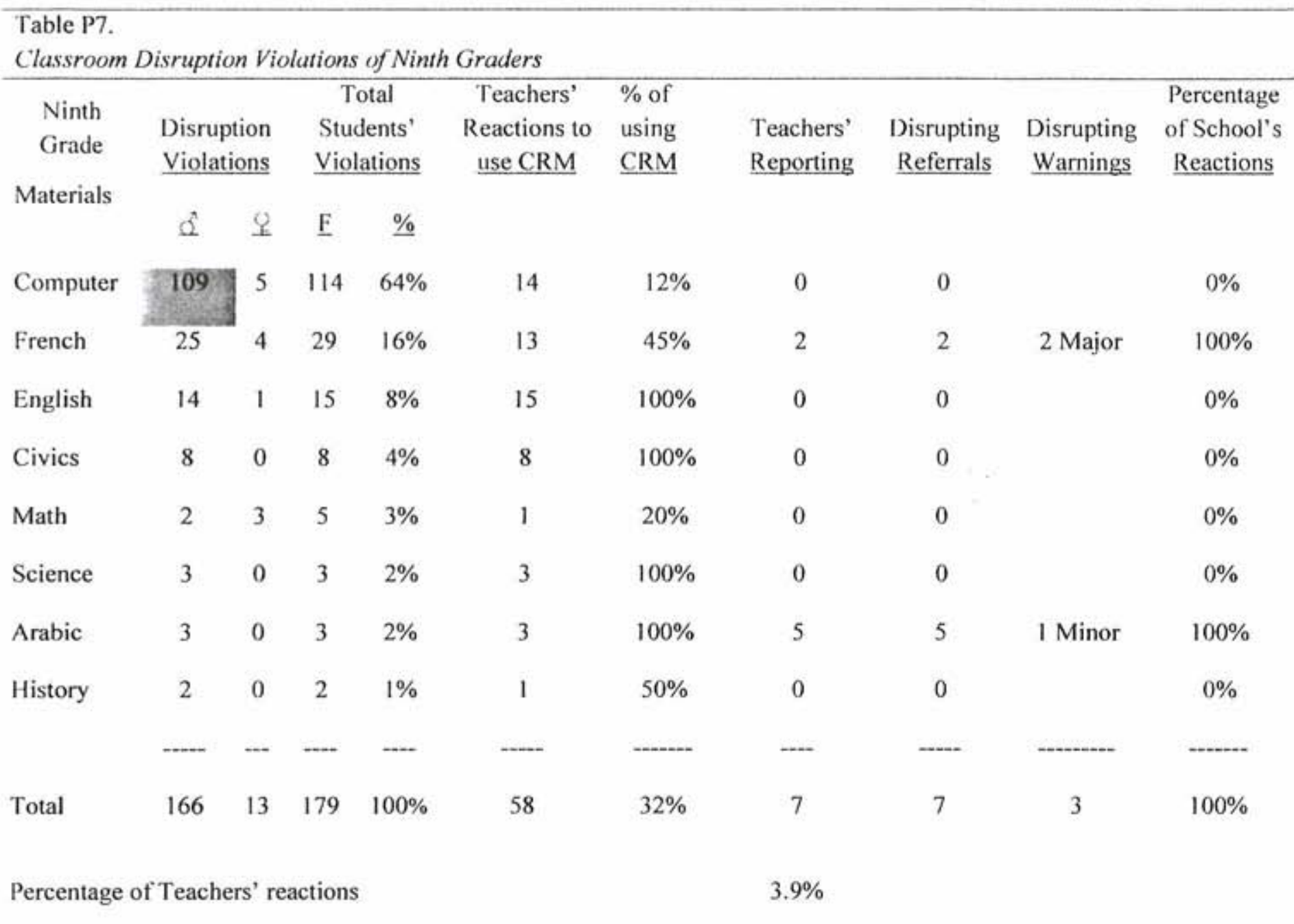

Note, $\mathrm{CRM}=\mathrm{Classroom} \mathrm{Management} ; \delta=$ Male; $\phi=$ Female $; \mathrm{F}=$ Frequency; $\%=$ Percentage; the percentage of using CRM is calculated by dividing frequency of the teacher's reactions to use CRM by the frequency of the students' violations. The percentage of the school's reactions to disruption is calculated by dividing the numbers of referrals by the frequency of teachers' reporting. The percentage of teachers' reporting is calculated by dividing the frequency of teachers' reporting by the frequency of students' violations. 


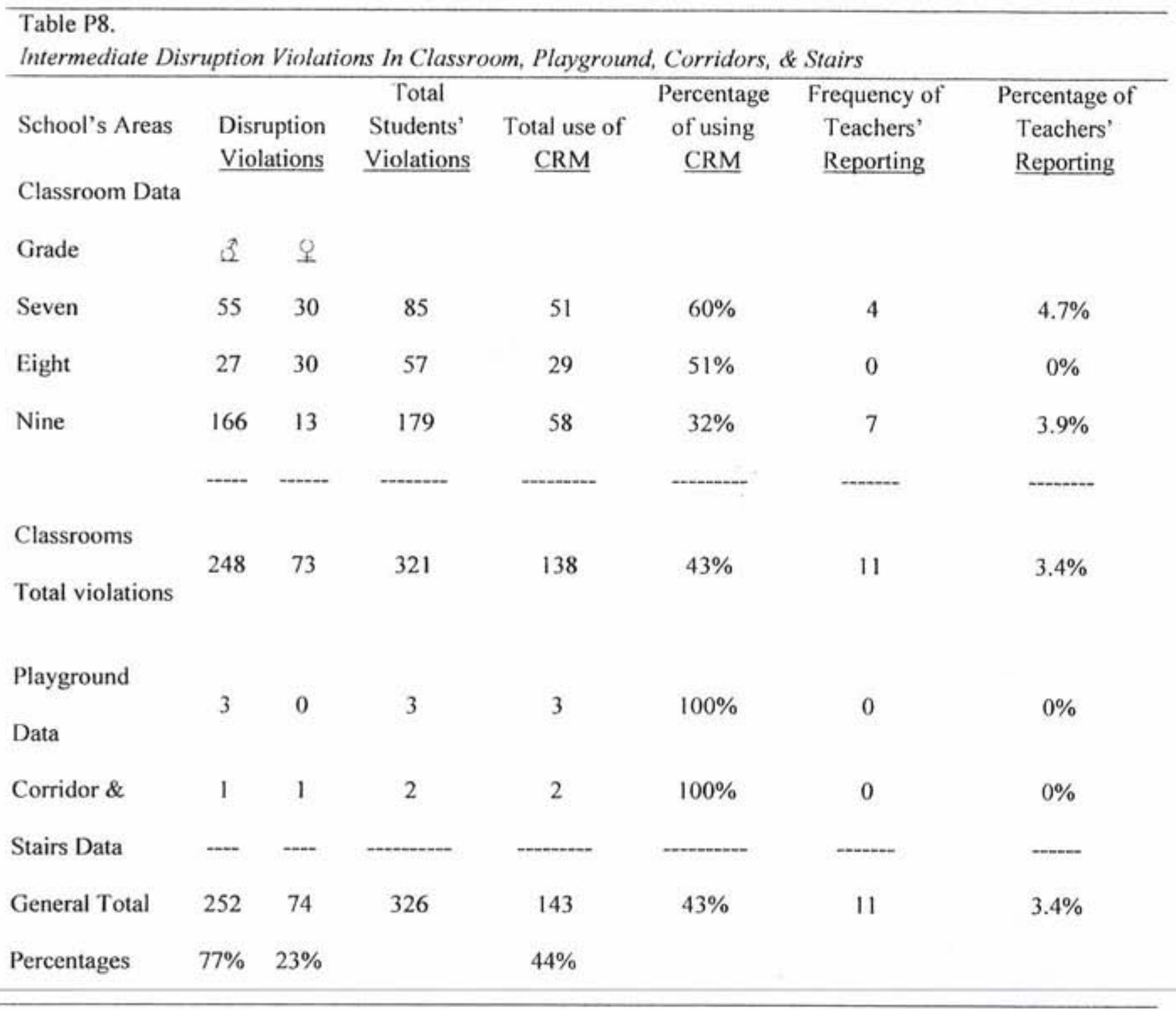

Note. $\delta=$ Male $;=$ Female; $C R M=$ Classroom Management;. The percentage of teachers' reporting is calculated by the frequency of teachers' reporting on students' disruptions by the total students' disruptions. 
Table P9.

Evaluation of Disruption Rule Enforcement

\begin{tabular}{|c|c|c|c|c|c|c|c|c|}
\hline \multirow[b]{4}{*}{ Grade } & \multirow{4}{*}{$\begin{array}{c}\text { Total } \\
\text { Students' } \\
\text { Disruption } \\
\end{array}$} & \multirow{4}{*}{$\begin{array}{c}\text { Frequency } \\
\text { of } \\
\text { Teachers' } \\
\text { Reporting }\end{array}$} & \multirow{4}{*}{$\begin{array}{c}\text { Percentage } \\
\text { of } \\
\text { Teachers' } \\
\text { Reporting }\end{array}$} & \multirow{4}{*}{$\begin{array}{c}\text { Evaluation } \\
\text { of } \\
\text { Teachers' } \\
\text { Reporting }\end{array}$} & \multicolumn{2}{|c|}{$\begin{array}{l}\text { Administrative Reactions } \\
\text { to Disruption }\end{array}$} & \multirow{2}{*}{$\begin{array}{c}\text { Percentage } \\
\text { of } \\
\text { Administ. }\end{array}$} & \multirow{4}{*}{$\underline{E A D E}$} \\
\hline & & & & & Disrupting & Disrupting & & \\
\hline & & & & & $\underline{\text { Referrals }}$ & Warnings & Reporting & \\
\hline & & & & & 요 오 & & & \\
\hline Seven & 85 & 4 & $4.7 \%$ & 4 & 4 & & $100 \%$ & 1 \\
\hline Eight & 57 & 0 & $0 \%$ & 5 & & & $0 \%$ & 5 \\
\hline \multirow[t]{3}{*}{ Nine } & & & & & & 2Major & & \\
\hline & 179 & 7 & $3.9 \%$ & 4 & 7 & 1 Minor & $100 \%$ & 1 \\
\hline & (n) & 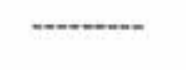 & $\cdots$ & $\cdots$ & $\cdots$ & -...... & -... & $\ldots$ \\
\hline Total & 321 & 11 & $3.4 \%$ & 4 & 11 & 3 & $100 \%$ & 1 \\
\hline
\end{tabular}

Note. $\delta=$ Male; $Q=$ Female; Administ $=$ Administration; EAE = Evaluation of Administrative Discipline Enforcement. The percentage of the administration's reactions on teachers' reporting is calculated by dividing the disruption referrals by the total teachers' reporting. (Evaluation Criteria: I= Highly Enforced; 2 = Quite Enforced; 3 = Moderately Enforced; 4 = Slightly Enforced; $5=$ Not Enforced). 


\begin{tabular}{|c|c|c|c|c|c|c|c|c|c|c|c|}
\hline \multirow{4}{*}{$\begin{array}{l}\text { Based on } \\
\text { Observation } \\
\text { Materials }\end{array}$} & \multicolumn{4}{|c|}{ Seventh Grade } & \multicolumn{4}{|c|}{ Eighth Grade } & \multicolumn{3}{|c|}{ Ninth Grade } \\
\hline & \multirow{2}{*}{\multicolumn{2}{|c|}{$\begin{array}{l}\text { Frequency } \\
\text { of H.W } \\
\text { Violations }\end{array}$}} & \multirow{3}{*}{\begin{tabular}{l}
\multicolumn{1}{c}{ Total } \\
Students' \\
Violation \\
\end{tabular}} & \multirow{3}{*}{$\begin{array}{l}\% \text { of } \\
\text { H.W } \\
\text { Viol. }\end{array}$} & \multirow{2}{*}{\multicolumn{2}{|c|}{$\begin{array}{c}\text { Frequency } \\
\text { of H.W } \\
\text { Violations }\end{array}$}} & \multirow{3}{*}{\begin{tabular}{l}
\multicolumn{1}{c}{ Total } \\
Students' \\
Violation \\
\end{tabular}} & \multirow{3}{*}{$\begin{array}{l}\% \text { of } \\
\text { H.W } \\
\text { Viol. }\end{array}$} & \multirow{2}{*}{$\begin{array}{c}\text { Frequency } \\
\text { of H.W } \\
\text { Violations } \\
\end{array}$} & \multirow{3}{*}{\begin{tabular}{c}
\multicolumn{1}{c}{ Total } \\
Students' \\
Violation \\
\end{tabular}} & \multirow{3}{*}{$\begin{array}{l}\% \text { of } \\
\text { H.W } \\
\text { Viol. }\end{array}$} \\
\hline & & & & & & & & & & & \\
\hline & $\hat{2}$ & 오 & & & 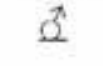 & ? & & & 오 & & \\
\hline Math & & & & & & 1 & 1 & $6 \%$ & & & \\
\hline Science & 4 & 4 & 8 & $19 \%$ & & & & & & & \\
\hline Physics & & & & & 1 & & 1 & $6 \%$ & & & \\
\hline Chemistry & & & & & & 2 & 2 & $13 \%$ & & & \\
\hline English & 5 & 4 & 9 & $21 \%$ & 1 & 2 & 3 & $18 \%$ & 1 & I & $4 \%$ \\
\hline Arabic & 2 & 1 & 3 & $7 \%$ & & & & & 3 & 3 & $14 \%$ \\
\hline Geography & 14 & 4 & 18 & $43 \%$ & 1 & 1 & 2 & $13 \%$ & & & \\
\hline History & & & & & & & & & 3 & 5 & $23 \%$ \\
\hline Social Studies & 1 & & 1 & $3 \%$ & & & & & & & \\
\hline Computer & & & & & & & & & 1 & 1 & $4 \%$ \\
\hline French & 3 & & 3 & $7 \%$ & 6 & 1 & 7 & $44 \%$ & 7 & 12 & $55 \%$ \\
\hline & $\cdots$ & $\ldots$ & -........ & & $\ldots$ & $\cdots$ & -non & & +- & wan & \\
\hline Total & 29 & 13 & 42 & & 9 & 7 & 16 & & $15 \quad 7$ & 22 & \\
\hline Percentages & $36 \%$ & $16 \%$ & $52 \%$ & & $11 \%$ & $9 \%$ & $20 \%$ & & $19 \% \quad 9 \%$ & $28 \%$ & \\
\hline Total H.W Vio & ations & & & & & & & 80 & & & \\
\hline Total H.W Viol & ations/C & Gender & & & & & $53 d$ & 27 & १ & & \\
\hline Percentage /Ge & nder & & & & & & $66 \%$ & ठ $34 \%$ & $\%$ ㅇ & & \\
\hline
\end{tabular}

Note. $\mathrm{H} . \mathrm{W}=$ Homework; $\delta=$ Male; $q=$ Female; Viol = Violations; $\%=$ Percentage. The percentage of H.W violations in each material is calculated by dividing the H.W violations in each material by the total students' violations. 


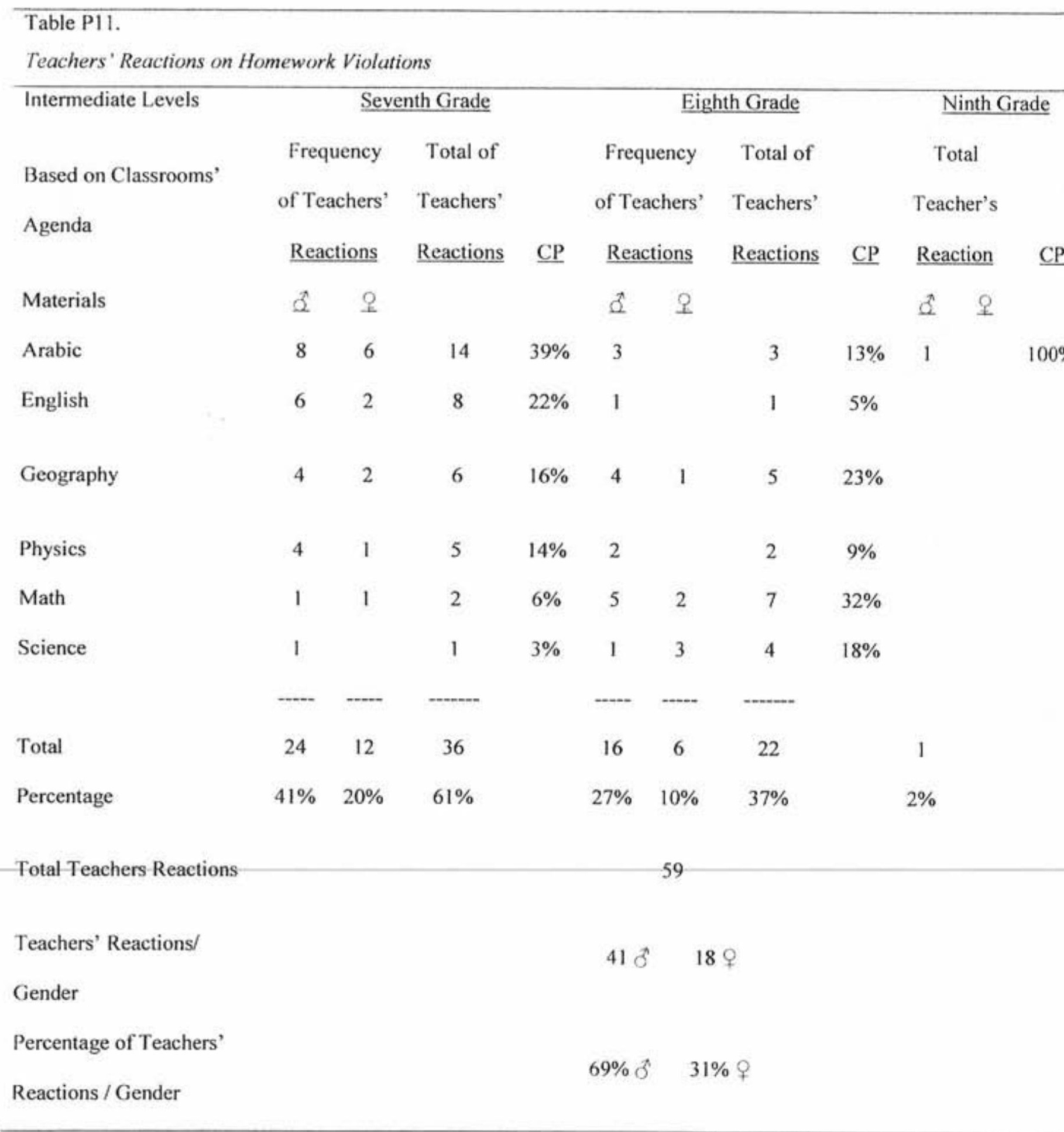


Table P12.

Evaluation of Homework Enforcement at Seventh Grade

\begin{tabular}{|c|c|c|c|c|c|c|c|c|c|}
\hline & Frequency & & Percentage & \multirow{2}{*}{\multicolumn{2}{|c|}{$\begin{array}{c}\text { Frequency } \\
\text { of H.W } \\
\text { Referrals }\end{array}$}} & \multirow{3}{*}{$\begin{array}{l}\text { Total H.W } \\
\text { Referrals }\end{array}$} & \multirow{3}{*}{$\underline{\text { PAR }}$} & \multirow{3}{*}{$\begin{array}{c}\text { PAR on } \\
\text { Students' } \\
\text { H.W } \\
\text { Violations }\end{array}$} & \multirow{3}{*}{$\begin{array}{c}\text { Evaluation } \\
\text { of H.W } \\
\text { Enforcement }\end{array}$} \\
\hline $\begin{array}{l}\text { Seventh } \\
\text { Grade }\end{array}$ & $\begin{array}{c}\text { of } \\
\text { Students' } \\
\text { Violations }\end{array}$ & $\begin{array}{c}\text { Frequency } \\
\text { of Teachers } \\
\text { Reactions }\end{array}$ & $\begin{array}{c}\text { of } \\
\text { Teachers' } \\
\text { Reactions }\end{array}$ & & & & & & \\
\hline Materials & & & & 3 & 오 & & & & \\
\hline Math & & 2 & $100 \%$ & & 2 & 2 & $100 \%$ & $100 \%$ & 1 \\
\hline Physics & & 5 & $100 \%$ & 6 & 1 & 7 & $100 \%$ & $100 \%$ & 1 \\
\hline Arabic & 3 & 14 & $100 \%$ & 7 & 4 & 11 & $79 \%$ & $100 \%$ & 1 \\
\hline English & 9 & 8 & $89 \%$ & 3 & 1 & 4 & $50 \%$ & $44 \%$ & 3 \\
\hline Geography & 18 & 6 & $33 \%$ & 2 & 1 & 3 & $50 \%$ & $17 \%$ & 4 \\
\hline Science & 8 & 1 & $12.5 \%$ & & & 0 & $0 \%$ & $0 \%$ & 5 \\
\hline Social & 1 & & $0 \%$ & & & & $0 \%$ & $0 \%$ & 5 \\
\hline Studies & & & & & & & & & \\
\hline French & 3 & & $0 \%$ & & & & $0 \%$ & $0 \%$ & 5 \\
\hline Total & 42 & 36 & $86 \%$ & 18 & 9 & 27 & $75 \%$ & $64 \%$ & 3 \\
\hline
\end{tabular}

Note. $\hat{\delta}=$ Male; $\phi=$ Female; H.W = Homework; PAR = Percentage of Administrative Reactions. The percentage of teachers' reactions is ealculated by dividing the total teachers' reactions by the total of students' H.W violations. The percentage of administrative reactions to teachers' reactions is calculated by dividing the number of referrals by the frequency of teachers' reactions. The percentage of administrative reactions to students' violations is calculated by dividing the number of referrals by the frequency of students' homework violations. (Evaluation Criteria: 1= Highly Ënforced; 2 = Quite Enforced; 3 = Moderately Enforced; 4 = Slightly Enforced; $5=$ Not Enforced). 


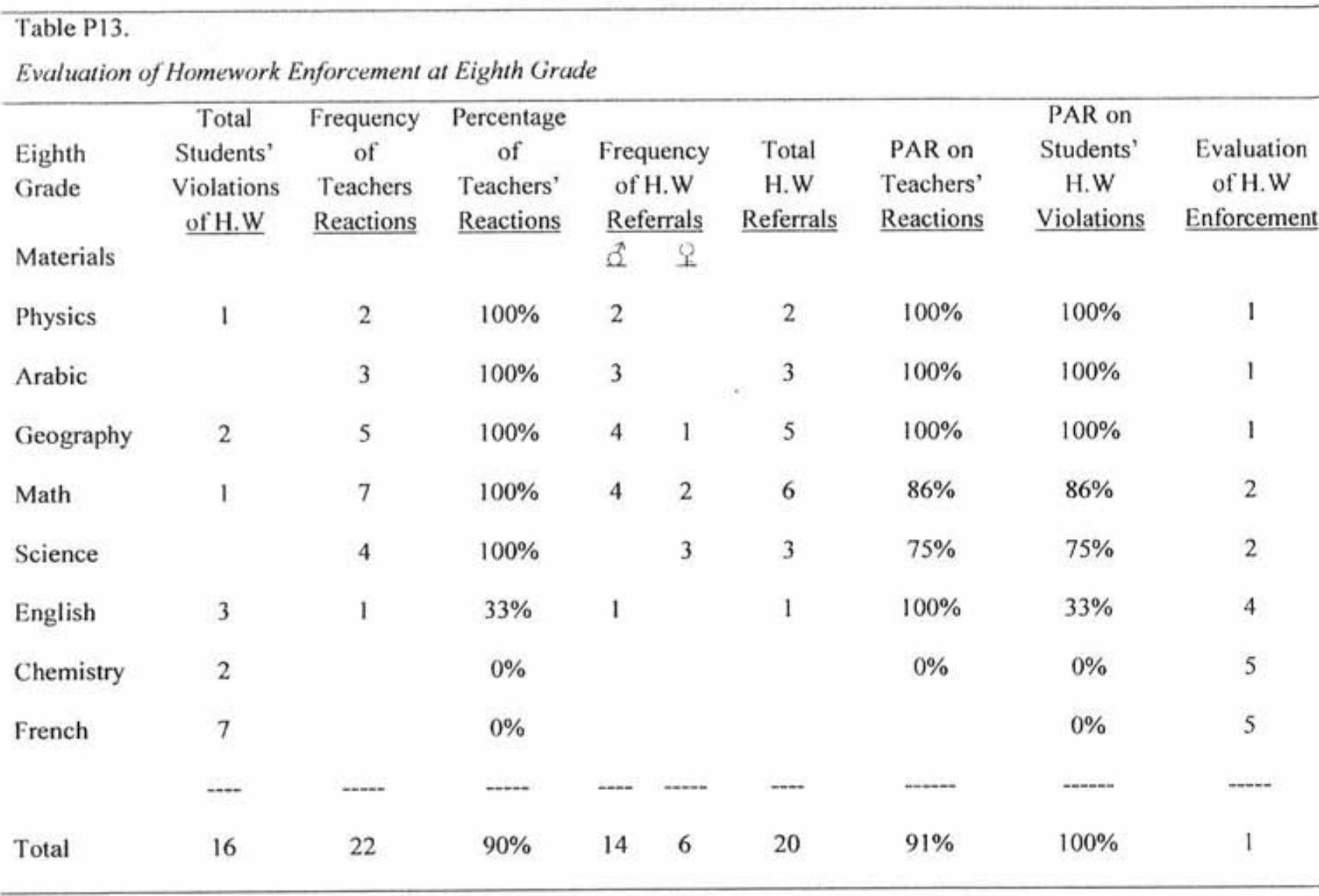

Note, $\hat{\delta}=$ Male; $q=$ Female; $\mathrm{H} . \mathrm{W}=$ Homework; $\mathrm{PAR}=$ Percentage of Administrative Reactions. The percentage of teachers' reactions is calculated by dividing the total teachers' reactions by the total of students' H.W violations. The percentage of administrative reactions to teachers' reactions is calculated by dividing the number of referrals by the frequency of teachers' reactions. The percentage of administrative reactions to students' violations is calculated by dividing the number of referrals by the frequency of students' homework violations. (Evaluation Criteria: I= Highly Enforced; 2 = Quite Enforced; 3 = Moderately Enforced; 4 = Slightly Enforced; 5= Not Enforced). 


\section{Table P14.}

Evaluation of Homework Enforcement at Ninth Grade

\begin{tabular}{|c|c|c|c|c|c|c|c|c|}
\hline $\begin{array}{l}\text { Ninth } \\
\text { Grade }\end{array}$ & $\begin{array}{c}\text { Total } \\
\text { Students' } \\
\text { Violations } \\
\text { of H.W }\end{array}$ & $\begin{array}{c}\text { Frequency } \\
\text { of } \\
\text { Teachers } \\
\text { Reactions }\end{array}$ & $\begin{array}{c}\text { Percentage } \\
\text { of } \\
\text { Teachers' } \\
\text { Reactions }\end{array}$ & $\begin{array}{c}\text { Frequency } \\
\text { of H.W } \\
\text { Referrals }\end{array}$ & $\begin{array}{c}\text { Total } \\
\text { H.W } \\
\text { Referrais } \\
\end{array}$ & $\begin{array}{l}\text { PAR on } \\
\text { Teachers' } \\
\text { Reporting }\end{array}$ & $\begin{array}{c}\text { PAR on } \\
\text { Students' } \\
\text { Violations } \\
\end{array}$ & $\begin{array}{c}\text { Evaluation } \\
\text { of H.W } \\
\text { Enforcement }\end{array}$ \\
\hline Materials & & & & 2 & & & & \\
\hline English & 1 & & $0 \%$ & & & & $0 \%$ & 5 \\
\hline Arabic & 3 & 1 & $33 \%$ & 1 & 1 & $100 \%$ & $33 \%$ & 4 \\
\hline History & 5 & & $0 \%$ & & & & $0 \%$ & 5 \\
\hline Computer & 2 & & $0 \%$ & & & & $0 \%$ & 5 \\
\hline \multirow[t]{2}{*}{ French } & 12 & & $0 \%$ & & & & $0 \%$ & 5 \\
\hline & -1.2n- & --o- & & $\cdots$ & $\ldots$ & $\cdots$ & -..n-... & -...- \\
\hline Total & 22 & 1 & $4.6 \%$ & 1 & 1 & $100 \%$ & $4.6 \%$ & 4 \\
\hline
\end{tabular}

Note. $\delta=$ Male $;=$ Female; H.W = Homework; PAR= Percentage of Administrative Reactions. The percentage of teachers' reactions is calculated by dividing the total teachers' reactions by the total of students' H.W violations. The percentage of administrative reactions to teachers' reactions is calculated by dividing the number of referrals by the frequency of teachers' reactions. The percentage of administrative reactions to students' violations is calculated by dividing the number of referrals by the frequency of students' homework violations. (Evaluation Criteria: $1=$ Highly Enforced; 2 = Quite Enforced; 3 = Moderately Enforced; 4 = Slightly Enforced; $5=$ Not Enforced). 


\section{Table P15.}

Evaluation of Homework Enforcement at Intermediate Levels

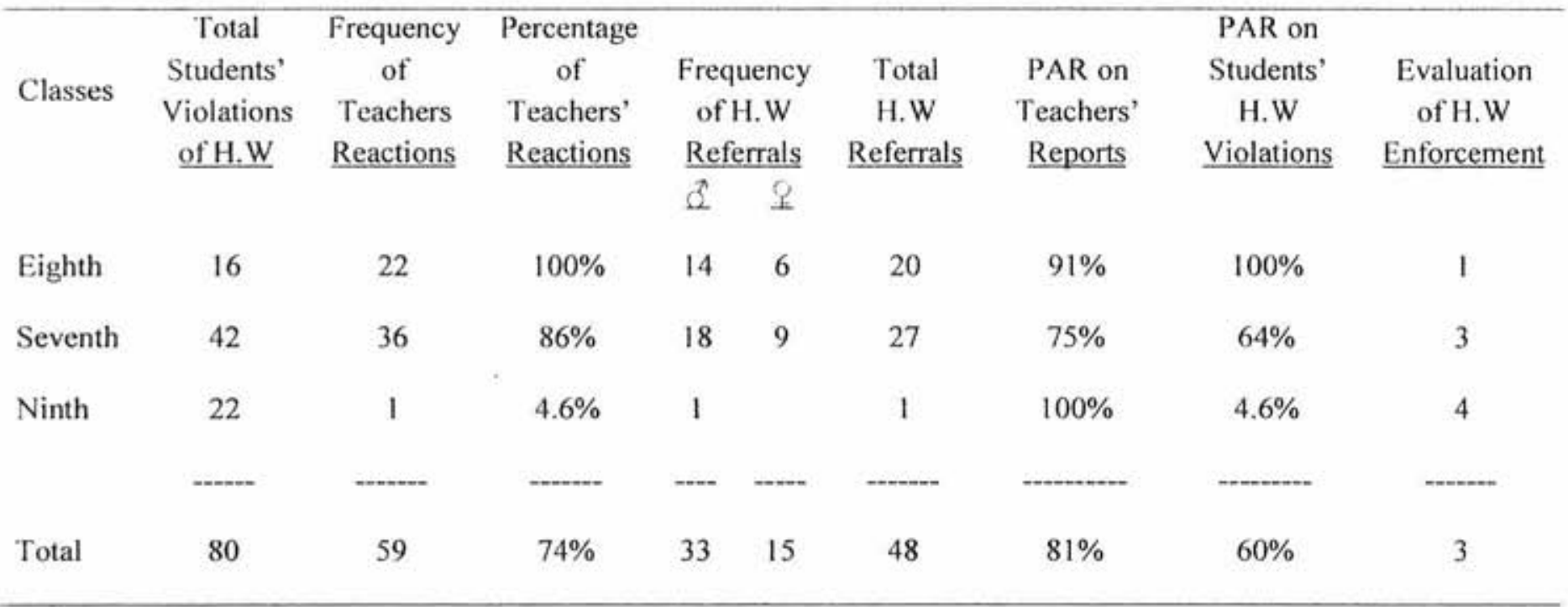

Note. $\delta^{\hat{f}}=$ Male; $q=$ Female; H.W = Homework; PAR= Percentage of Administrative Reactions. The percentage of teachers' reactions is calculated by dividing the total teachers' reactions by the total of students' H.W violations. The percentage of administrative reactions to teachers' reactions is calculated by dividing the number of referrals by the frequency of teachers' reactions. The percentage of administrative reactions to students' violations is calculated by dividing the number of referrals by the frequency of students' homework violations. (Evaluation Criteria: 1= Highly Enforced; 2 = Quite Enforced; 3 = Moderately Enforced; 4 = Slightly Enforced; $5=$ Not Enforced). 


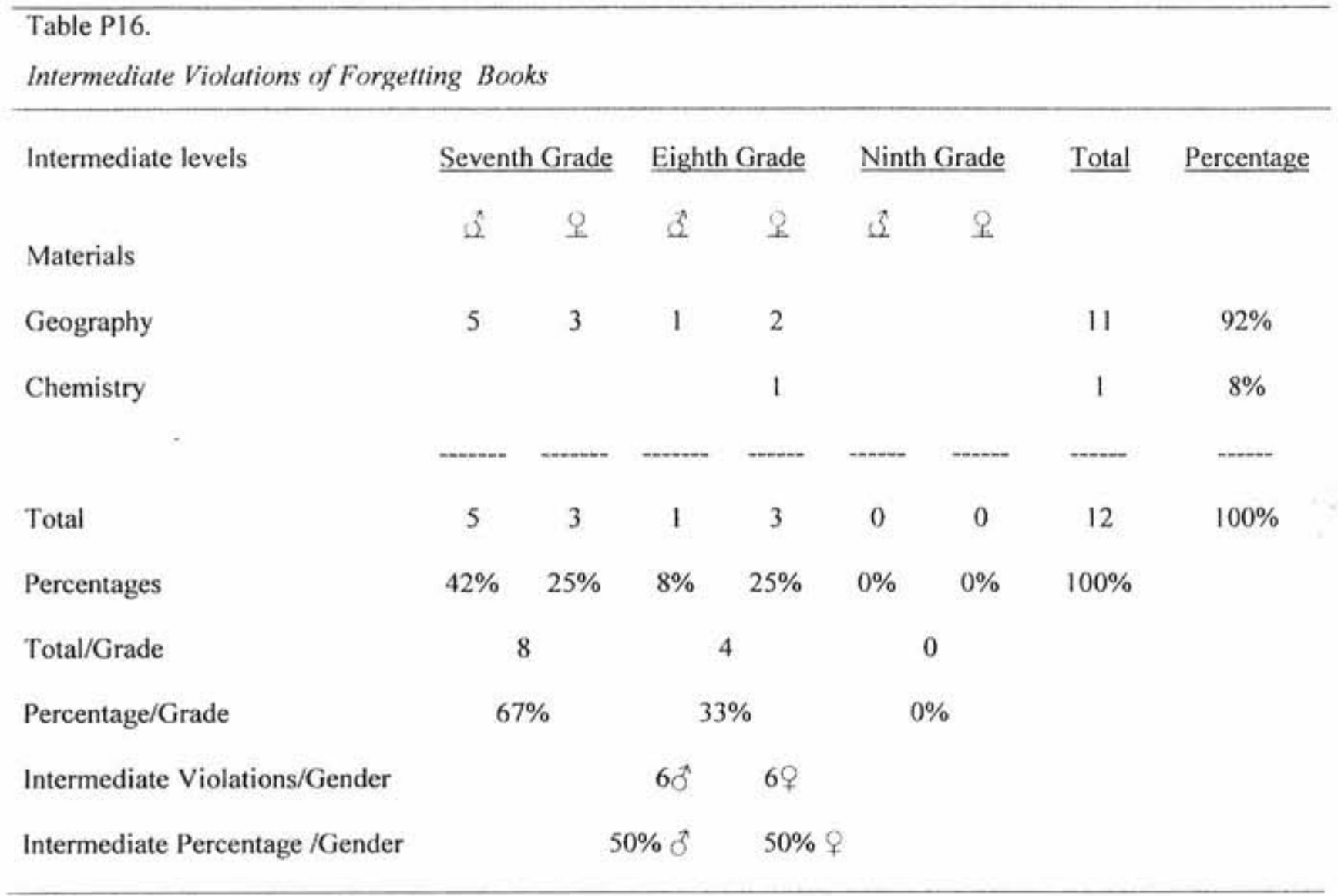

Note. $\delta=$ Male; $\phi=$ Female. 


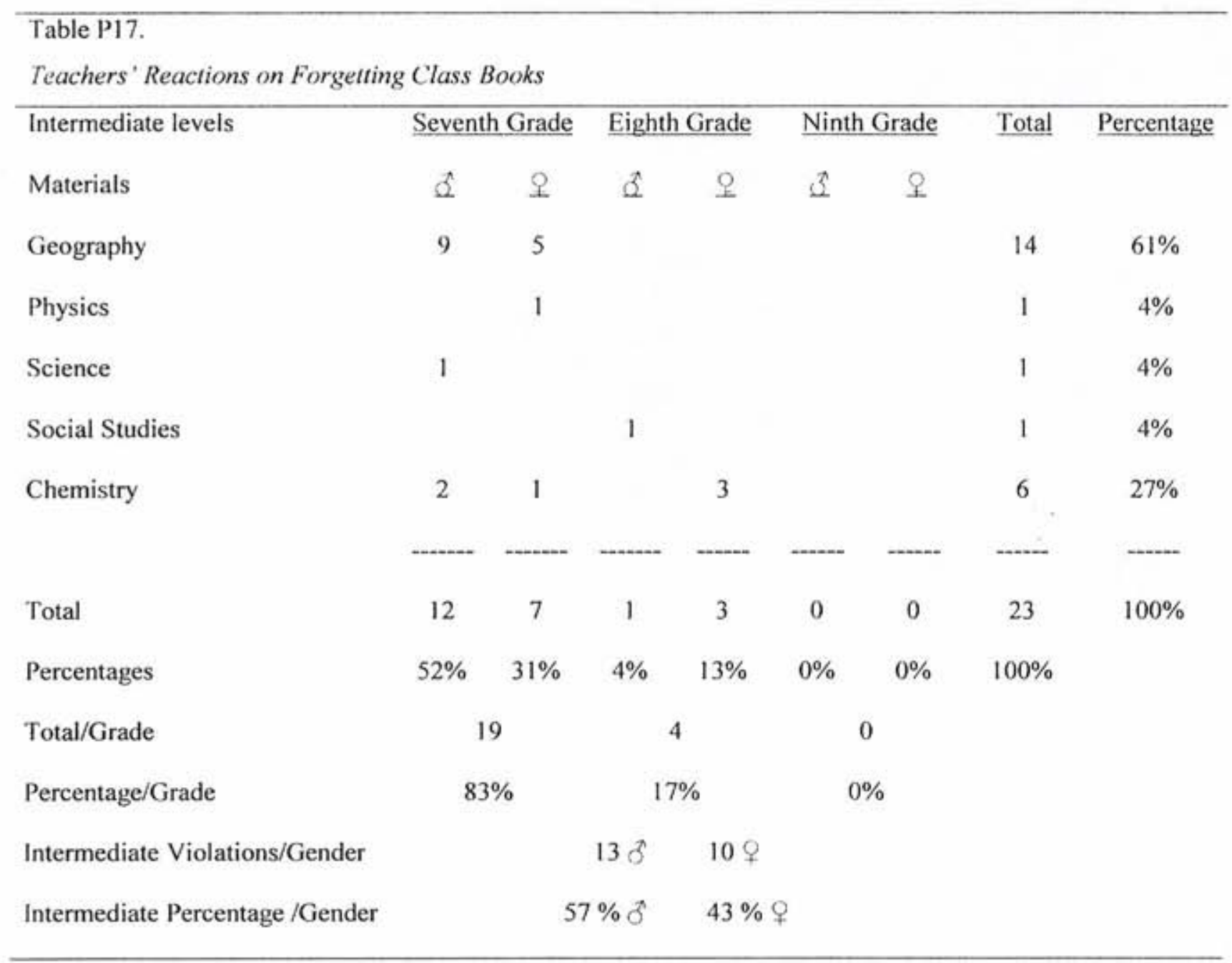

Note, $\delta^{*}=$ Male; $Q=$ Female. 


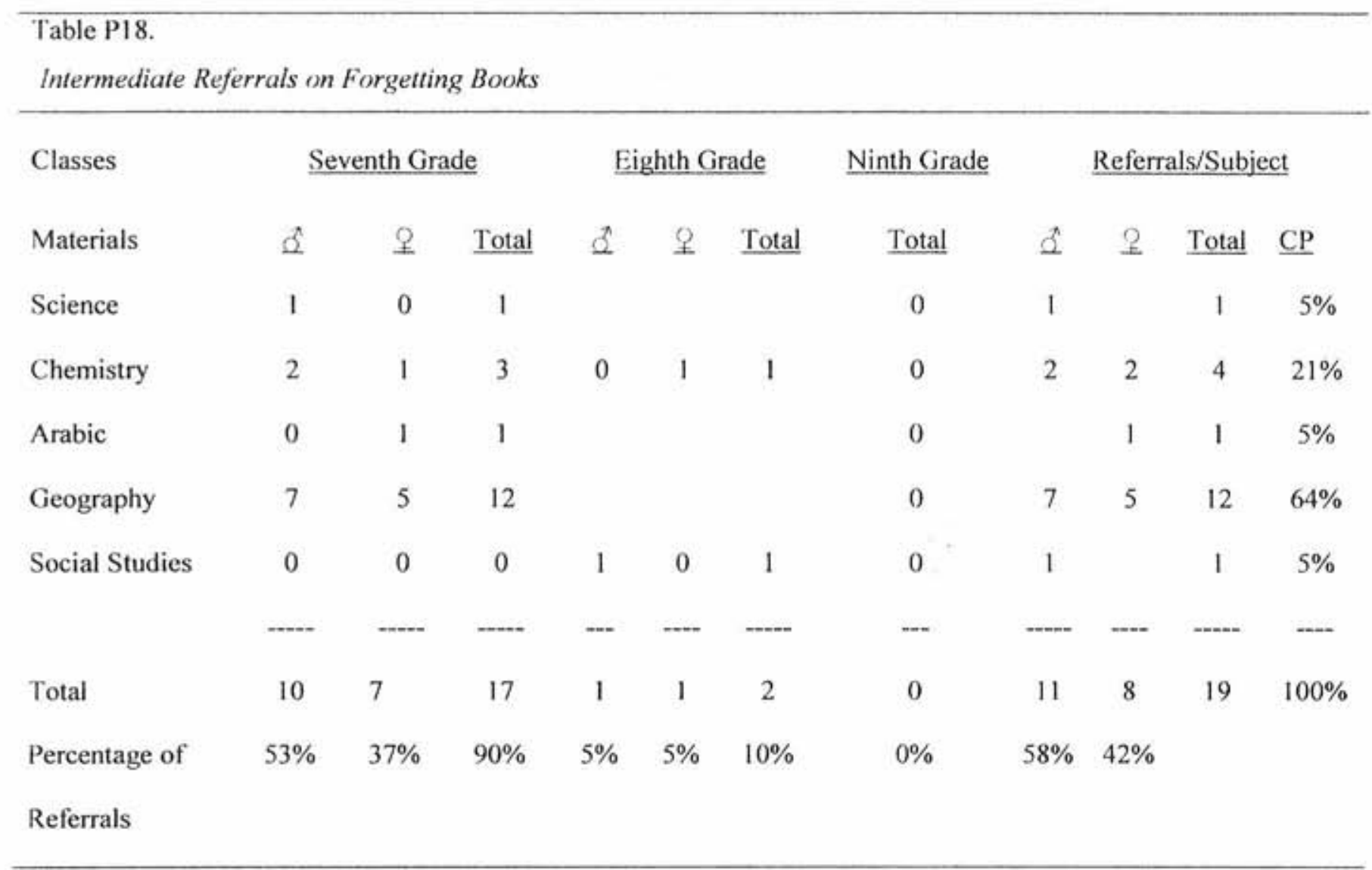

Note. $\hat{\delta}=$ Male $; \phi=$ Female $\cdot \mathrm{Cp}=$ Corresponding Percentage 


\begin{tabular}{|c|c|c|c|c|c|c|}
\hline \multicolumn{7}{|c|}{ Evaluation of Bringing Classroom Materials at Seventh Grade } \\
\hline Seventh Grade & 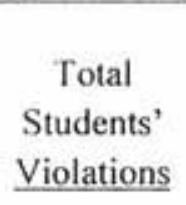 & $\begin{array}{l}\text { Frequency } \\
\text { of 'Teachers' } \\
\text { Reactions }\end{array}$ & $\begin{array}{l}\text { Percentage } \\
\text { of Teachers' } \\
\text { Reactions }\end{array}$ & $\begin{array}{l}\text { Frequency } \\
\text { of Referrals }\end{array}$ & $\begin{array}{c}\text { Percentage of } \\
\text { Administrative } \\
\text { Reactions on } \\
\text { Teachers' Reports }\end{array}$ & $\begin{array}{l}\text { Evaluation of } \\
\text { Enforcement }\end{array}$ \\
\hline \multicolumn{7}{|l|}{ Materials } \\
\hline Geography & 8 & 14 & $74 \%$ & 12 & $86 \%$ & 2 \\
\hline Physics & & 1 & $5 \%$ & & $0 \%$ & 5 \\
\hline Science & & 1 & $5 \%$ & 1 & $100 \%$ & 1 \\
\hline Arabic & & & & 1 & $100 \%$ & 1 \\
\hline \multirow[t]{2}{*}{ Chemistry } & & 3 & $16 \%$ & 3 & $100 \%$ & 1 \\
\hline & - & $\cdots$ & & $\cdots$ & $\cdots$ & $\cdots$ \\
\hline Total & 8 & 19 & $100 \%$ & 17 & $90 \%$ & 1 \\
\hline
\end{tabular}

Note. The percentage of teachers' reactions is calculated by dividing the total teachers' reactions by the total of students' violations. The percentage of administrative reactions to teachers' reactions is calculated by dividing the number of referrals by the frequency of teachers' reactions. (Evaluation Criteria: $1=$ Highly Enforced; 2 = Quite Enforced; 3 = Moderately Enforced; 4 =Slightly Enforced; $5=$ Not Enforced). 


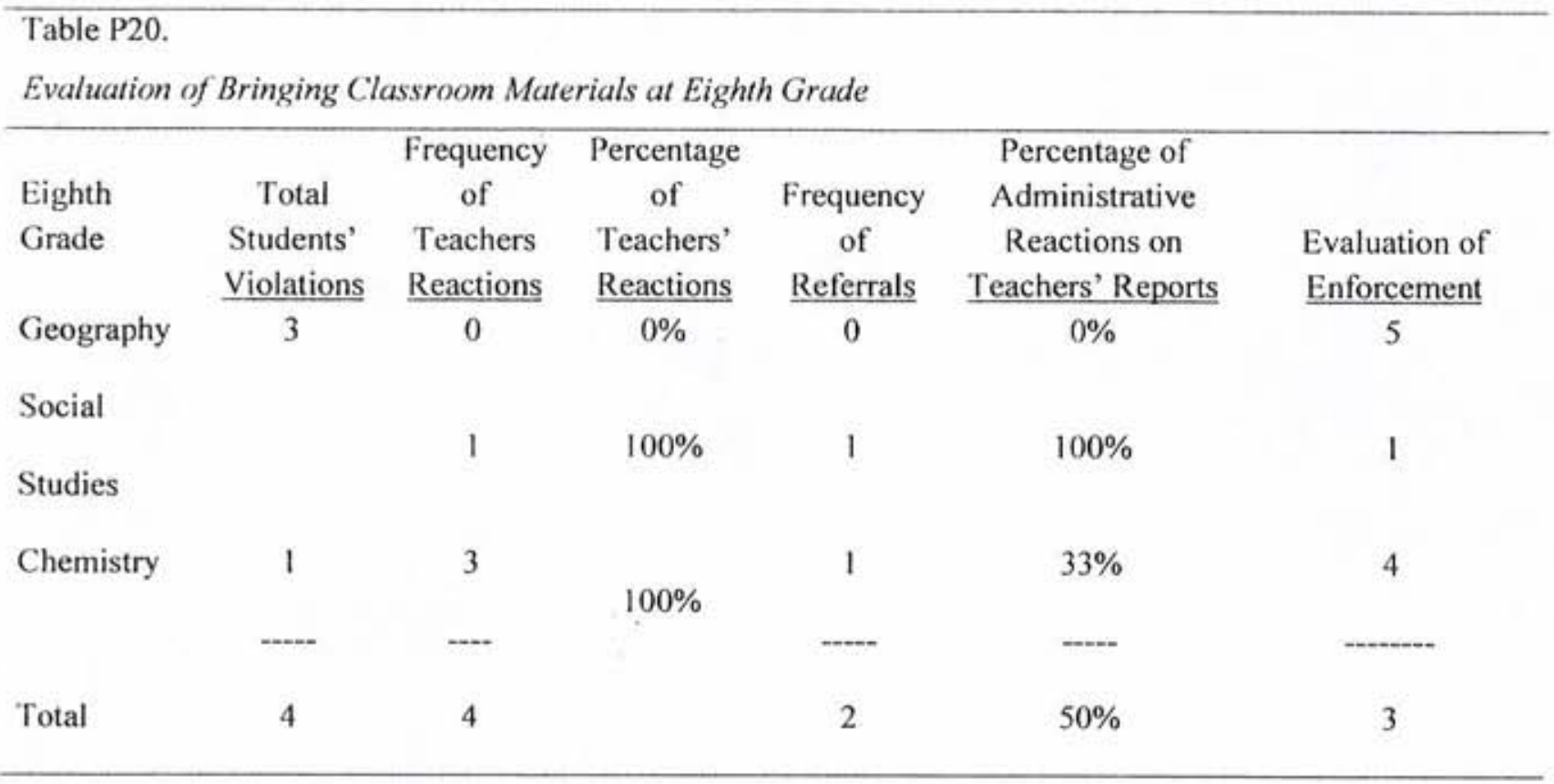

Note. The percentage of teachers' reactions is calculated by dividing the total teachers' reactions by the total of students' violations. The percentage of administrative reactions to teachers' reactions is calculated by dividing the number of referrals by the frequency of teachers' reactions. (Evaluation Criteria: $1=$ Highly Enforced; $2=$ Quite Enforced; 3 = Moderately Enforced; $4=$ Slightly Enforced; $5=$ Not Enforced). 
Table P21.

Evaluation of Bringing Classroom Materials at Ninth Grade

\begin{tabular}{|c|c|c|c|c|c|c|}
\hline $\begin{array}{l}\text { Intermediate } \\
\text { Levels }\end{array}$ & \begin{tabular}{c}
\multicolumn{1}{c}{ Total } \\
Students' \\
Violations \\
\end{tabular} & $\begin{array}{c}\text { Frequency } \\
\text { of Teachers } \\
\text { Reactions }\end{array}$ & $\begin{array}{c}\text { Percentage } \\
\text { of Teachers' } \\
\text { Reactions }\end{array}$ & $\begin{array}{c}\text { Frequency } \\
\text { of } \\
\text { Referrals }\end{array}$ & $\begin{array}{c}\text { Percentage of } \\
\text { Administrative } \\
\text { Reactions on } \\
\text { Teachers' Reports }\end{array}$ & $\begin{array}{l}\text { Evaluation of } \\
\text { Enforcement }\end{array}$ \\
\hline Seventh Grade & 8 & 19 & $100 \%$ & 17 & $90 \%$ & 2 \\
\hline Eighth Grade & 4 & 4 & $100 \%$ & 2 & $50 \%$ & 3 \\
\hline Total & 12 & 23 & $100 \%$ & 19 & $83 \%$ & 2 \\
\hline
\end{tabular}

Note. The percentage of teachers' reactions is calculated by dividing the total teachers' reactions by the total of students' violations. The percentage of administrative reactions to teachers' reactions is calculated by dividing the number of referrals by the frequency of teachers' reactions. (Evaluation Criteria: $1=$ Highly Enforced; 2 = Quite Enforced; $3=$ Moderately Enforced; $4=$ Slightly Enforced; $5=$ Not Enforced). 
Table P22.

Evaluation of Uniform Code Enforcement

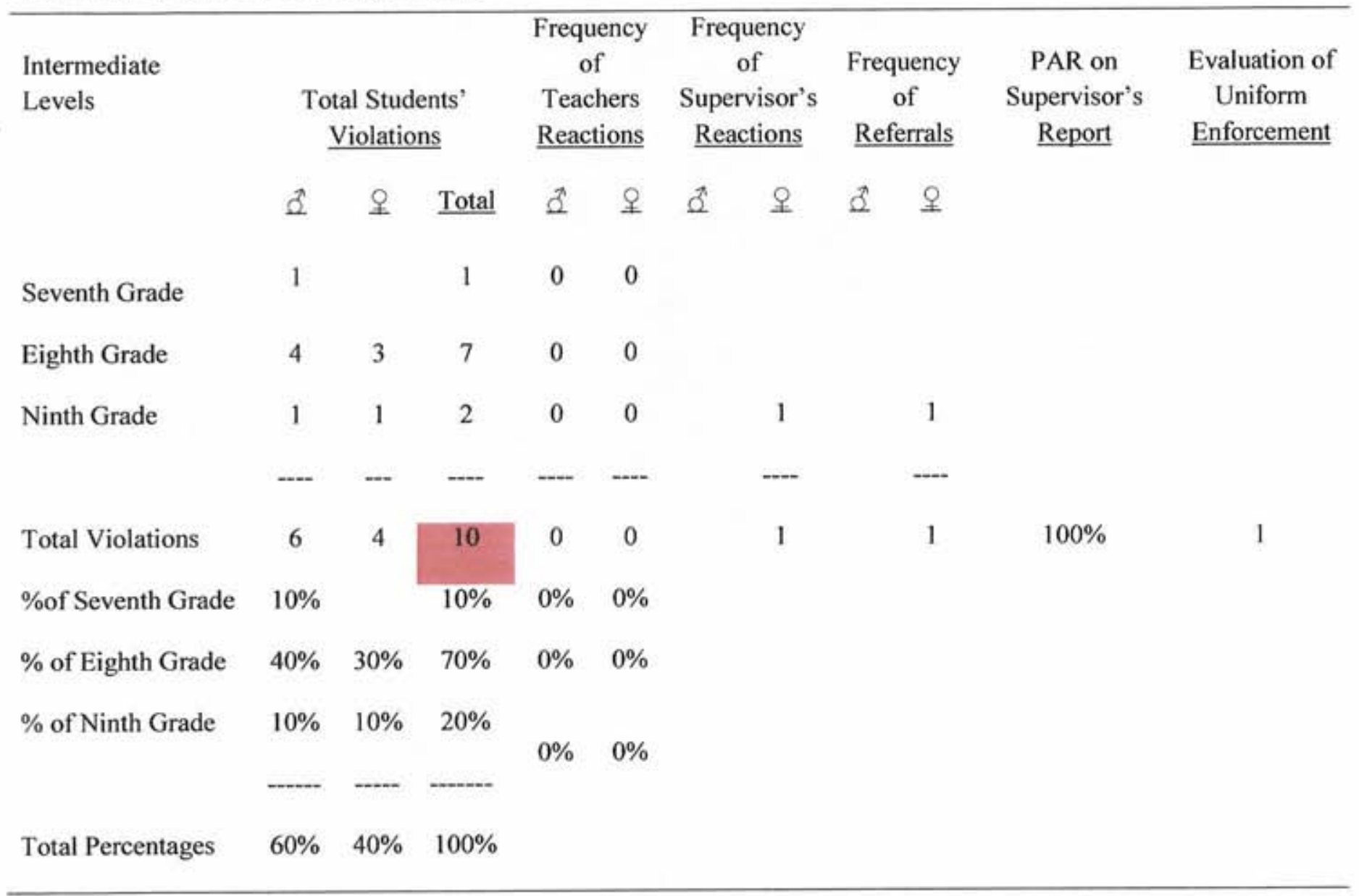

Note. $\delta=$ Male $; q=$ Female $; \%=$ Percentage; PAR = Percentage of Administrative Reactions; $\%=$ Percentage. The percentage of teachers ${ }^{\prime}$ reactions is calculated by dividing the total teachers' reactions by the total of students' violations. The percentage of administrative reactions to teachers' reactions is calculated by dividing the number of referrals by the frequency of teachers' reactions. The playground data are included. (Evaluation Criteria: 1= Highly Enforced; 2 = Quite Enforced; 3 = Moderately Enforced; 4 = Slightly Enforced; $5=$ Not Enforced). 
Table P23.

Evaluation of Hair Code Enforcement

\begin{tabular}{|c|c|c|c|c|c|c|c|c|c|c|c|}
\hline \multirow[t]{2}{*}{$\begin{array}{l}\text { Intermediate } \\
\text { Levels }\end{array}$} & \multicolumn{3}{|c|}{$\begin{array}{c}\text { Total Students' } \\
\text { Violations }\end{array}$} & \multicolumn{2}{|c|}{$\begin{array}{c}\text { Frequency of } \\
\text { Teachers } \\
\text { Reactions }\end{array}$} & \multicolumn{2}{|c|}{$\begin{array}{l}\text { Frequency of } \\
\text { Supervisor's } \\
\text { Reactions }\end{array}$} & \multicolumn{2}{|c|}{$\begin{array}{l}\text { Frequency } \\
\text { of Referrals }\end{array}$} & \multirow[t]{2}{*}{$\begin{array}{l}\text { PAR on } \\
\text { Teachers' } \\
\text { Reports }\end{array}$} & \multirow[t]{2}{*}{$\begin{array}{c}\begin{array}{c}\text { Evaluation } \\
\text { of }\end{array} \\
\text { Enforcement } \\
\end{array}$} \\
\hline & है & 오 & $\underline{\text { Total }}$ & \& & 오 & $\underline{2}$ & 오 & 8 & 오 & & \\
\hline Seventh Grade & 11 & & 11 & & & & & & & & \\
\hline Eighth Grade & 23 & 1 & 24 & 1 & & & & & & & \\
\hline Ninth Grade & 1 & 0 & 1 & 1 & & & & & & & \\
\hline & $\cdots$ & - & $\cdots$ & $\cdots$ & & & & & & & \\
\hline Total & 35 & 1 & 36 & 2 & & 0 & 0 & 0 & 0 & $0 \%$ & 5 \\
\hline $\begin{array}{l}\% \text { of Seventh } \\
\text { Grade }\end{array}$ & $31 \%$ & & $31 \%$ & $0 \%$ & $0 \%$ & & & & & & \\
\hline $\begin{array}{l}\% \text { of Eighth } \\
\text { Grade }\end{array}$ & $63 \%$ & $3 \%$ & $66 \%$ & $6 \%$ & $0 \%$ & & & & & & \\
\hline$\%$ of Ninth & $3 \%$ & $0 \%$ & $3 \%$ & $0 \%$ & $0 \%$ & & & & & & \\
\hline Grade & $\cdots$ & $\cdots$ & -+ & $\cdots$ & $\cdots$ & & & & & & \\
\hline Percentages & $97 \%$ & $3 \%$ & $100 \%$ & $6 \%$ & & & & & & & \\
\hline
\end{tabular}

Note. $\hat{\delta}=$ Male; $\phi=$ Female; PAR = Percentage of Administrative Reactions. The percentage of teachers' reactions is calculated by dividing the total teachers' reactions by the total of students' violations; $\%=$ percentage. The percentage of administrative reactions to teachers' reactions is calculated by dividing the number of referrals by the frequency of teachers' reactions. The playground data are included. (Evaluation Criteria: 1= Highly Enforced; 2 = Quite Enforced; 3 = Moderately Enforced; 4 = Slightly Enforced; $5=$ Not Enforced). 
Table P24.

Evaluation of Jewelry Code Enforcement

\begin{tabular}{|c|c|c|c|c|c|c|c|c|c|c|c|}
\hline \multirow[t]{2}{*}{$\begin{array}{l}\text { Intermediate } \\
\text { Levels }\end{array}$} & \multicolumn{3}{|c|}{$\begin{array}{c}\text { Total Students' } \\
\text { Violations }\end{array}$} & \multicolumn{2}{|c|}{$\begin{array}{l}\text { Frequency } \\
\text { of Teachers } \\
\text { Reactions }\end{array}$} & \multicolumn{2}{|c|}{$\begin{array}{c}\text { Frequency of } \\
\text { Supervisor's } \\
\text { Reactions }\end{array}$} & \multicolumn{2}{|c|}{$\begin{array}{c}\text { Frequency } \\
\text { of } \\
\text { Referrals }\end{array}$} & \multirow[t]{2}{*}{$\begin{array}{l}\text { PAR on } \\
\text { Teachers' } \\
\text { Reports }\end{array}$} & \multirow[t]{2}{*}{$\begin{array}{l}\text { Evaluation of } \\
\text { Enforcement }\end{array}$} \\
\hline & $\underline{2}$ & 오 & $\underline{\text { Total }}$ & $\hat{2}$ & 오 & 2 & 오 & 2 & 오 & & \\
\hline Seventh Grade & 17 & 16 & 33 & - & -- & - & -. & & & & 5 \\
\hline Eighth Grade & 32 & 31 & 63 & - & - & - & 1 & & & & 4 \\
\hline \multirow[t]{2}{*}{ Ninth Grade } & 29 & 12 & 41 & - & -- & -- & - & & & & 5 \\
\hline & -- & -- & $\ldots$ & - & $\cdots$ & $\cdots$ & $-n$ & & & & \\
\hline Total & 78 & 59 & 137 & 0 & 0 & 0 & 1 & 0 & 0 & $0 \%$ & 5 \\
\hline $\begin{array}{l}\text { Percentage of } \\
\text { Seventh Grade }\end{array}$ & $12 \%$ & $12 \%$ & $24 \%$ & $0 \%$ & $0 \%$ & & & & & & \\
\hline $\begin{array}{l}\text { Percentage of } \\
\text { Eighth Grade }\end{array}$ & $23 \%$ & $23 \%$ & $46 \%$ & $0 \%$ & $0 \%$ & & & & & & \\
\hline Percentage of & $21 \%$ & $9 \%$ & $30 \%$ & $0 \%$ & $0 \%$ & & & & & & \\
\hline Ninth Grade & $\ldots$ & -.... & $-\cdots$ & $\cdots$ & $\cdots$ & & & & & & \\
\hline Percentages & $56 \%$ & $44 \%$ & $100 \%$ & $0 \%$ & $0 \%$ & & & & & & \\
\hline
\end{tabular}

Note. $\delta^{\prime}=$ Male $; q=$ Female; $P A R=$ Percentage of Administrative Reactions. The percentage of teachers' reactions is calculated by dividing the total teachers' reactions by the total of students' violations. The percentage of administrative reactions to teachers' reactions is calculated by dividing the number of referrals by the frequency of teachers' reactions. The data collected from the playground is included. (Evaluation Criteria: 1= Highly Enforced; 2 = Quite Enforced; 3 = Moderately Enforced; 4 =Slightly Enforced; $5=$ Not Enforced). 
Table P25.

Intermediate Bullying Violations

\begin{tabular}{|c|c|c|c|c|c|c|}
\hline \multirow[b]{2}{*}{ Kinds of Bullying } & \multicolumn{3}{|c|}{ Frequency of Bullying } & \multicolumn{3}{|c|}{ Percentages of Bullying } \\
\hline & $\underline{\text { Male }}$ & Female & $\underline{\text { Total }}$ & Male & $\underline{\text { Female }}$ & $\underline{\text { Total }}$ \\
\hline Emotional Bullying & 30 & 9 & 39 & $16 \%$ & $4 \%$ & $20 \%$ \\
\hline Verbal Bullying & 61 & 1 & 62 & $32 \%$ & $1 \%$ & $33 \%$ \\
\hline Physical Bullying & 74 & 15 & 89 & $39 \%$ & $8 \%$ & $47 \%$ \\
\hline Total Bullying & 165 & 25 & 190 & $87 \%$ & $13 \%$ & $100 \%$ \\
\hline
\end{tabular}

Note. The percentage is calculated by dividing the frequency by the total violations 
Table P26.

Classroom \& Playground Emotional Bullying Violations

\begin{tabular}{|c|c|c|c|c|c|c|c|}
\hline \multicolumn{2}{|l|}{ Intermediate } & \multicolumn{3}{|c|}{ Frequency of Students' Violations } & \multicolumn{3}{|c|}{ Percentages of Students' Violations } \\
\hline Levels & School's Areas & Males & Females & $\underline{\text { Total }}$ & Males & Females & $\underline{\text { Total }}$ \\
\hline Seventh & Playground & 2 & 0 & 2 & $5 \%$ & $0 \%$ & $5 \%$ \\
\hline \multirow[t]{3}{*}{ Grade } & & 5 & 0 & 5 & $13 \%$ & $0 \%$ & $13 \%$ \\
\hline & Classroom & & & & & & \\
\hline & Seventh Grade Total & 7 & 0 & 7 & $18 \%$ & $0 \%$ & $18 \%$ \\
\hline Eighth Grade & Classroom & 4 & 3 & 7 & $10 \%$ & $8 \%$ & $18 \%$ \\
\hline \multirow[t]{2}{*}{ Ninth Grade } & Classroom & 19 & 6 & 25 & $49 \%$ & $15 \%$ & $64 \%$ \\
\hline & & - & --- & $\cdots$ & $\cdots$ & $\ldots$ & $-\cdots$ \\
\hline \multicolumn{2}{|c|}{ Total Intermediate Violations } & 30 & 9 & 39 & $77 \%$ & $23 \%$ & $100 \%$ \\
\hline \multicolumn{2}{|c|}{ Total Playground Violations } & 2 & 0 & 2 & $5 \%$ & $0 \%$ & $5 \%$ \\
\hline \multicolumn{2}{|c|}{ Total Classroom Violations } & 28 & 9 & 37 & $72 \%$ & $23 \%$ & $95 \%$ \\
\hline
\end{tabular}

Note. The percentages are calculated by dividing the frequency of violation by the total number of violations. 
Table P27.

Evaluation of Emotional Bullying Code Enforcement

\begin{tabular}{|c|c|c|c|c|c|c|c|c|c|c|c|c|}
\hline \multirow{2}{*}{$\begin{array}{l}\text { Intermediate } \\
\text { Levels } \\
\text { Grades }\end{array}$} & \multicolumn{3}{|c|}{$\begin{array}{c}\text { Total Students' } \\
\text { Violations }\end{array}$} & \multicolumn{3}{|c|}{$\begin{array}{c}\text { Frequency of } \\
\text { Teachers Reactions }\end{array}$} & \multicolumn{2}{|c|}{$\begin{array}{c}\text { Frequency of } \\
\text { Supervisor's } \\
\underline{\text { Reactions }}\end{array}$} & \multicolumn{2}{|c|}{$\begin{array}{c}\text { Frequency } \\
\text { of } \\
\text { Referrals }\end{array}$} & \multirow[t]{2}{*}{$\begin{array}{l}\text { PAR to } \\
\text { Teachers } \\
\text { Reports }\end{array}$} & \multirow[t]{2}{*}{$\begin{array}{l}\text { Evaluation o } \\
\text { Enforcemen }\end{array}$} \\
\hline & 2. & 오 & $\underline{\text { Total }}$ & 2 & 오 & Total & d. & 오 & s. & 오 & & \\
\hline Seventh & 7 & 0 & 7 & 3 & 0 & 3 & 0 & 0 & 0 & 0 & 0 & \\
\hline Eighth & 4 & 3 & 7 & 3 & 2 & 5 & 0 & 0 & 0 & 0 & 0 & \\
\hline \multirow[t]{2}{*}{ Ninth } & 19 & 6 & 25 & 9 & 0 & 9 & 0 & 0 & 0 & 0 & 0 & \\
\hline & $\cdots$ & $\cdots$ & $\cdots$ & $\cdots$ & - & $-\cdots$ & -.- & $\cdots$ & $-\cdots$ & $\cdots$ & & \\
\hline Total & 30 & 9 & 39 & 15 & 2 & 17 & 0 & 0 & 0 & 0 & 0 & 5 \\
\hline$\%$ of Seventh & $18 \%$ & $0 \%$ & $18 \%$ & $60 \%$ & $0 \%$ & $60 \%$ & $0 \%$ & $0 \%$ & $0 \%$ & $0 \%$ & $0 \%$ & 5 \\
\hline$\%$ of Eighth & $10 \%$ & $8 \%$ & $18 \%$ & $43 \%$ & $28 \%$ & $71 \%$ & $0 \%$ & $0 \%$ & $0 \%$ & $0 \%$ & $0 \%$ & 5 \\
\hline \multirow[t]{2}{*}{$\%$ of Ninth } & $49 \%$ & $15 \%$ & $64 \%$ & $36 \%$ & $0 \%$ & $36 \%$ & $0 \%$ & $0 \%$ & $0 \%$ & $0 \%$ & $0 \%$ & 5 \\
\hline & $\cdots$ & $\cdots$ & $\cdots$ & $\cdots$ & $\cdots$ & $\cdots$ & $\cdots$ & $\cdots$ & $\cdots$ & $\cdots$ & & \\
\hline Percentages & $77 \%$ & $23 \%$ & $100 \%$ & $41 \%$ & $5 \%$ & $46 \%$ & $0 \%$ & $0 \%$ & $0 \%$ & $0 \%$ & $0 \%$ & 5 \\
\hline
\end{tabular}

Note. $\hat{\delta}=$ Male; $q=$ Female; PAR = Percentage of Administrative Reactions; $\%=$ Percentage. The percentage of teachers' reactions is calculated by dividing the total teachers' reactions by the total of students' violations in classroom only. The percentage of administrative reactions to teachers' reactions is calculated by dividing the number of referrals by the frequency of teachers' reactions. The data collected from the playground is included. (Evaluation Criteria: 1= Highly Enforced; 2 = Quite Enforced; 3 = Moderately Enforced; 4 = Slightly Enforced; 5 = Not Enforced). 
Table P28.

Classroom \& Playground Verbal Bullying Violations

\begin{tabular}{|c|c|c|c|c|c|c|c|}
\hline \multicolumn{2}{|l|}{ Intermediate } & \multicolumn{3}{|c|}{ Frequency of Students' Violations } & \multicolumn{3}{|c|}{ Percentages of Students' Violations } \\
\hline Levels & School's Areas & $\underline{\text { Males }}$ & $\underline{\text { Females }}$ & $\underline{\text { Total }}$ & $\underline{\text { Males }}$ & $\underline{\text { Females }}$ & $\underline{\text { Total }}$ \\
\hline Seventh & Playground & 7 & 0 & 7 & $11 \%$ & $0 \%$ & $11 \%$ \\
\hline \multirow[t]{3}{*}{ Grade } & & 5 & 1 & 6 & $8 \%$ & $2 \%$ & $10 \%$ \\
\hline & Classioomin & $\cdots$ & $\ldots$ & 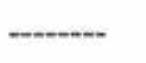 & $\cdots$ & ---- & $\cdots$ \\
\hline & $\begin{array}{l}\text { Total of Seventh } \\
\text { Graders }\end{array}$ & 12 & 1 & 13 & $19 \%$ & $2 \%$ & $21 \%$ \\
\hline Eighth & Playground & 15 & 0 & 15 & $24 \%$ & $0 \%$ & $24 \%$ \\
\hline \multirow[t]{2}{*}{ Grade } & Classroom & 6 & 0 & 6 & $10 \%$ & $0 \%$ & $10 \%$ \\
\hline & $\begin{array}{l}\text { Total of Eighth } \\
\text { Graders }\end{array}$ & 21 & 0 & 21 & $34 \%$ & $0 \%$ & $34 \%$ \\
\hline \multirow[t]{3}{*}{ Ninth Grade } & Playground & 19 & 0 & 19 & $31 \%$ & $0 \%$ & $31 \%$ \\
\hline & Classroom & 9 & 0 & 9 & $14 \%$ & $0 \%$ & $14 \%$ \\
\hline & $\begin{array}{l}\text { Total of Ninth } \\
\text { Graders }\end{array}$ & 28 & 0 & 28 & 45 & $0 \%$ & $45 \%$ \\
\hline \multicolumn{2}{|c|}{ Total Violations in Playground } & 41 & 0 & 41 & $66 \%$ & $0 \%$ & $66 \%$ \\
\hline \multicolumn{2}{|c|}{ Total Violations in Classroom } & 20 & 1 & 21 & $32 \%$ & $2 \%$ & $34 \%$ \\
\hline \multicolumn{2}{|c|}{ Total Intermediate Violations } & 61 & 1 & 62 & $98 \%$ & $2 \%$ & $100 \%$ \\
\hline
\end{tabular}




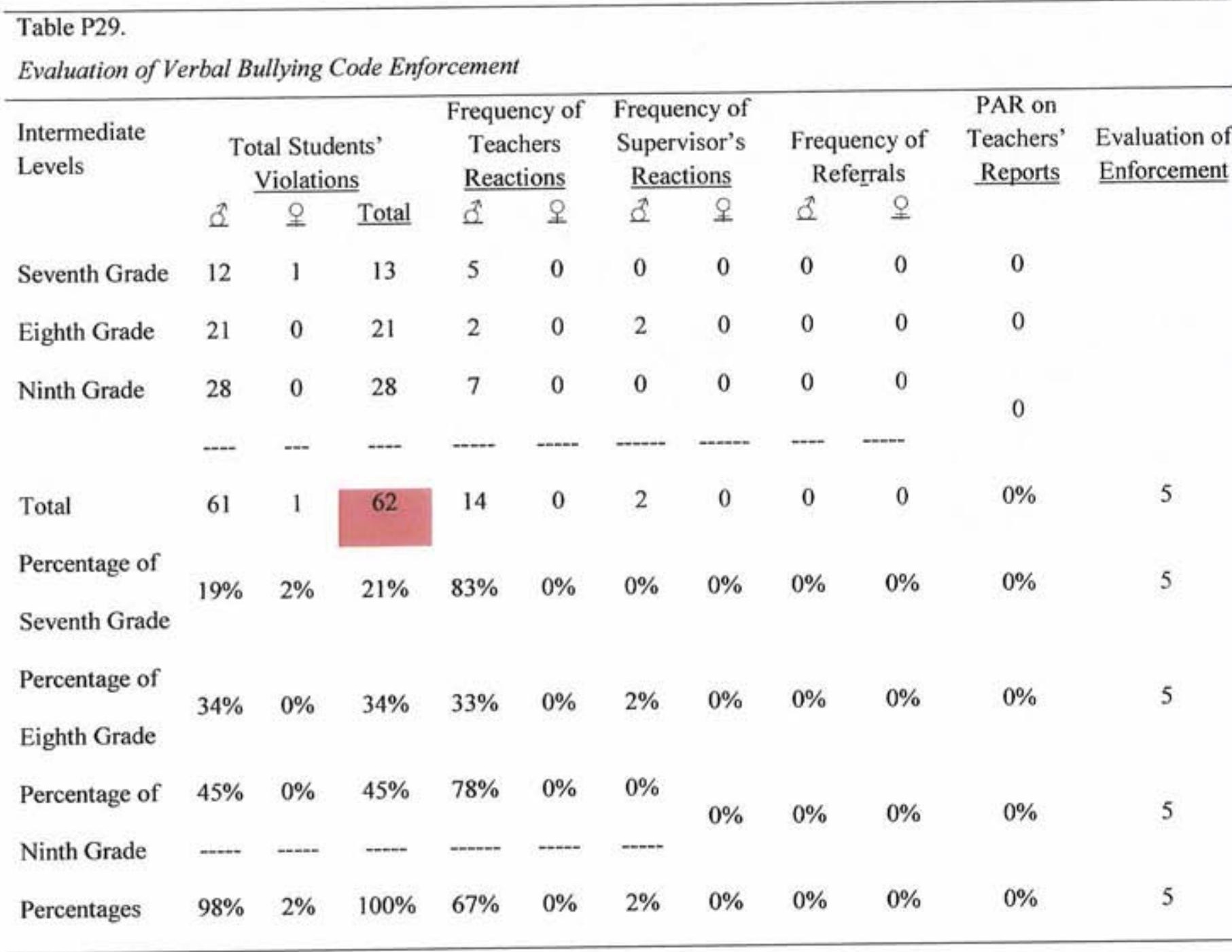

Note. $\hat{\delta}=$ Male; $q=$ Female; $\mathrm{PAR}=$ Percentage of Administrative Reactions. The data collected from the playground is included.

Percentage of teachers' reactions is calculated by the frequency of teachers' reactions over the total students' violations in classroom only. Percentage of supervisor's reactions is calculated by the frequency of supervisor's reactions over the total students' violations in playground only (Evaluation Criteria: 1= Highly Enforced; 2 = Quite Enforced; 3 = Moderately Enforced; 4 = Slightly Enforced; $5=$ Not Enforced). 


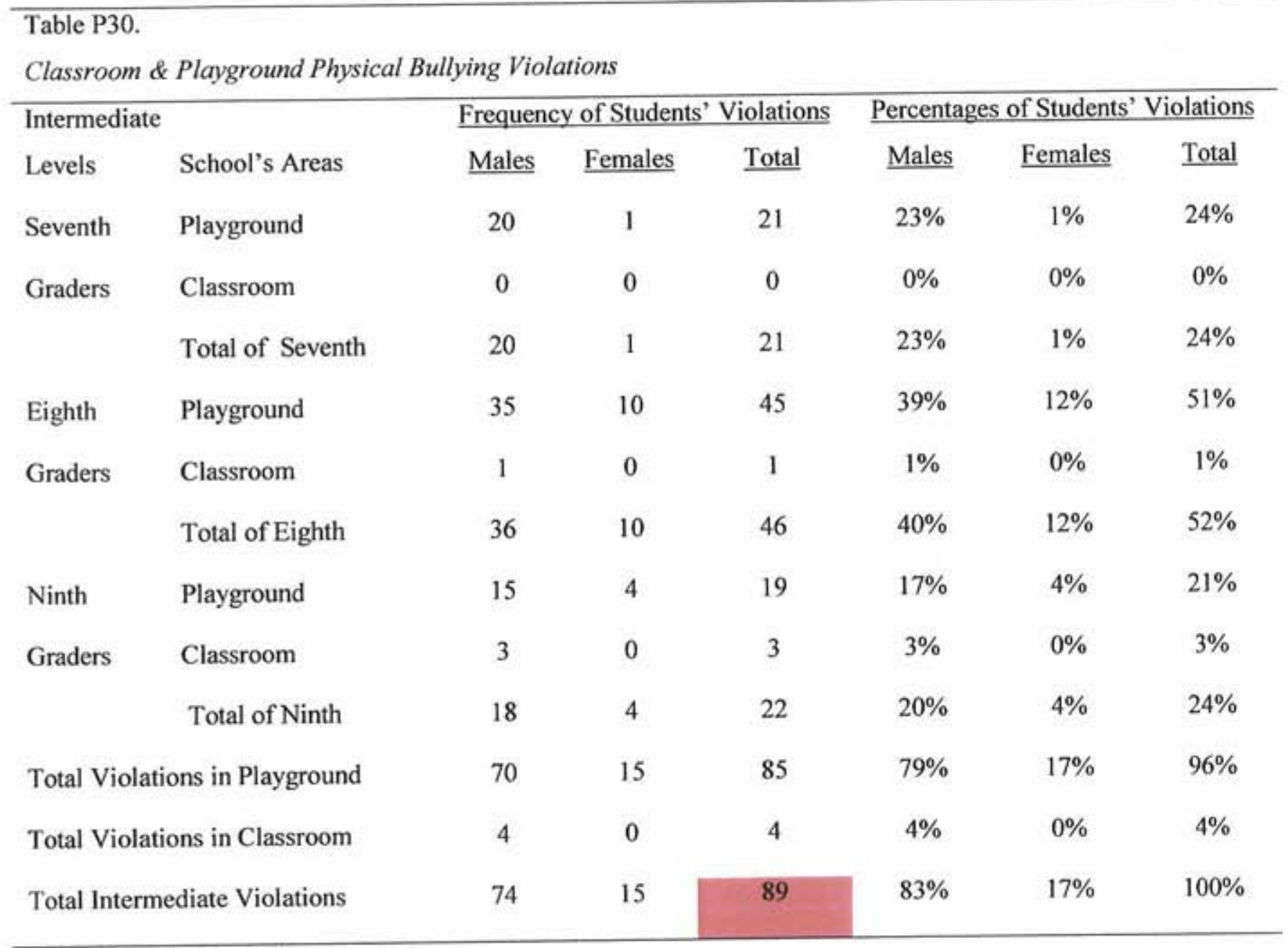




\begin{tabular}{|c|c|c|c|c|c|c|c|c|c|c|c|}
\hline \multirow[t]{2}{*}{$\begin{array}{l}\text { Intermediate } \\
\text { Levels }\end{array}$} & \multicolumn{3}{|c|}{$\begin{array}{c}\text { Total Students' } \\
\text { Violations }\end{array}$} & \multicolumn{2}{|c|}{$\begin{array}{c}\text { Frequency } \\
\text { of Teachers } \\
\text { Reactions }\end{array}$} & \multicolumn{2}{|c|}{$\begin{array}{l}\text { Frequency of } \\
\text { Supervisor's } \\
\text { Reactions }\end{array}$} & \multirow{2}{*}{\multicolumn{3}{|c|}{$\begin{array}{l}\text { PAR on } \\
\text { Teachers' } \\
\text { Reports }\end{array}$}} & \multirow[t]{2}{*}{$\begin{array}{l}\text { Evaluation of } \\
\text { Enforcement }\end{array}$} \\
\hline & 2 & 오 & Total & 2 & 오 & 2 & 오 & & & & \\
\hline Seventh Grade & 20 & 1 & 21 & 0 & 0 & 0 & 0 & 0 & 0 & 0 & \\
\hline Eighth Grade & 36 & 10 & 46 & 0 & 0 & 0 & 0 & 0 & 0 & 0 & \\
\hline \multirow[t]{2}{*}{ Ninth Grade } & 18 & 4 & 22 & 2 & 0 & 1 & 0 & 0 & 0 & 0 & \\
\hline & $\cdots$ & - & -- & $-\cdots$ & $\cdots$ & $\cdots$ & --.-- & $\cdots$ & (-) & & \\
\hline Total & 74 & 15 & 89 & 2 & 0 & 1 & 0 & 0 & 0 & $0 \%$ & 5 \\
\hline$\%$ of Seventh & $23 \%$ & $1 \%$ & $24 \%$ & $0 \%$ & $0 \%$ & $0 \%$ & $0 \%$ & $0 \%$ & $0 \%$ & $0 \%$ & 5 \\
\hline$\%$ of Eighth & $40 \%$ & $12 \%$ & $52 \%$ & $0 \%$ & $0 \%$ & $0 \%$ & $0 \%$ & $0 \%$ & $0 \%$ & $0 \%$ & 5 \\
\hline \multirow[t]{2}{*}{$\%$ of Ninth } & $20 \%$ & $4 \%$ & $24 \%$ & $50 \%$ & $0 \%$ & $50 \%$ & $0 \%$ & $0 \%$ & $0 \%$ & $0 \%$ & 5 \\
\hline & $\cdots$ & $\cdots$ & $\cdots$ & $\cdots$ & $\cdots$ & -+ & + & $\cdots$ & $\cdots$ & & \\
\hline Percentages & $83 \%$ & $17 \%$ & $100 \%$ & $50 \%$ & $0 \%$ & $50 \%$ & $0 \%$ & $0 \%$ & $0 \%$ & $0 \%$ & 5 \\
\hline
\end{tabular}

Note. $\delta=$ Male $; \phi=$ Female. Par = Percentage of Administrative reactions. The percentage of teachers' reactions is calculated by dividing the total teachers' reactions by the total of students' violations in classroom only. The percentage of administrative reactions to teachers' reactions is calculated by dividing the number of referrals by the frequency of teachers' reactions. The data collected from the playground is included. (Evaluation Criteria: 1= Highly Enforced; 2 = Quite Enforced; 3 = Moderately Enforced; $4=$ Slightly Enforced; $5=$ Not Enforced). 
Table P32.

Evaluation of Not Using Bad Language Code Enforcement

\begin{tabular}{|c|c|c|c|c|c|c|c|c|c|c|c|c|}
\hline \multicolumn{2}{|c|}{ Intermediate Levels } & \multicolumn{3}{|c|}{$\begin{array}{c}\text { Total Students' } \\
\text { Violations }\end{array}$} & \multicolumn{2}{|c|}{$\begin{array}{c}\begin{array}{c}\text { Frequency } \\
\text { of } \\
\text { Teachers }\end{array} \\
\text { Reactions }\end{array}$} & \multicolumn{2}{|c|}{$\begin{array}{c}\begin{array}{c}\text { Frequency } \\
\text { of } \\
\text { Supervisor's } \\
\text { Reactions }\end{array} \\
\end{array}$} & \multicolumn{2}{|c|}{$\begin{array}{c}\text { Frequency of } \\
\text { Referrals }\end{array}$} & \multirow[t]{2}{*}{$\begin{array}{l}\text { PAR on } \\
\text { Teachers' } \\
\text { Reports }\end{array}$} & \multirow[t]{2}{*}{$\begin{array}{l}\text { Evaluation of } \\
\text { Enforcement }\end{array}$} \\
\hline Grade & & 2 & 오 & \% & $\hat{2}$ & 오 & 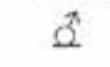 & 오 & 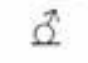 & 오 & & \\
\hline \multirow[t]{2}{*}{ Seventh } & Playground & 0 & 0 & $0 \%$ & & & & & & & & \\
\hline & Classroom & 0 & 0 & $0 \%$ & & & & & & & & \\
\hline \multirow[t]{2}{*}{ Eighth } & Playground & 0 & 0 & $0 \%$ & 0 & 0 & 0 & 0 & 0 & 0 & & \\
\hline & Classroom & 2 & 0 & $18 \%$ & & & & & & & & \\
\hline \multirow[t]{3}{*}{ Ninth } & Playground & 6 & 0 & $55 \%$ & 0 & 0 & 0 & 0 & 0 & 0 & & \\
\hline & Classroom & 3 & 0 & $27 \%$ & 0 & 0 & 0 & 0 & 0 & 0 & & \\
\hline & & $\cdots$ & - & $\cdots$ & - & $\cdots$ & $-\cdots$ & $\cdots$ & $\cdots$ & -- & & \\
\hline \multicolumn{2}{|l|}{ Total } & 11 & 0 & $100 \%$ & 0 & 0 & 0 & 0 & 0 & 0 & 0 & 5 \\
\hline \multicolumn{2}{|c|}{ Total violations in } & 5 & 0 & $45 \%$ & & & & & & & & \\
\hline \multicolumn{2}{|c|}{ Total violations in } & 6 & 0 & $55 \%$ & & & & & & & & \\
\hline Playgrou & & & & & & & & & & & & \\
\hline
\end{tabular}

Note. $\delta=$ Male; $Q=$ Female $;$ PAR = Percentage of Administrative Reactions, 


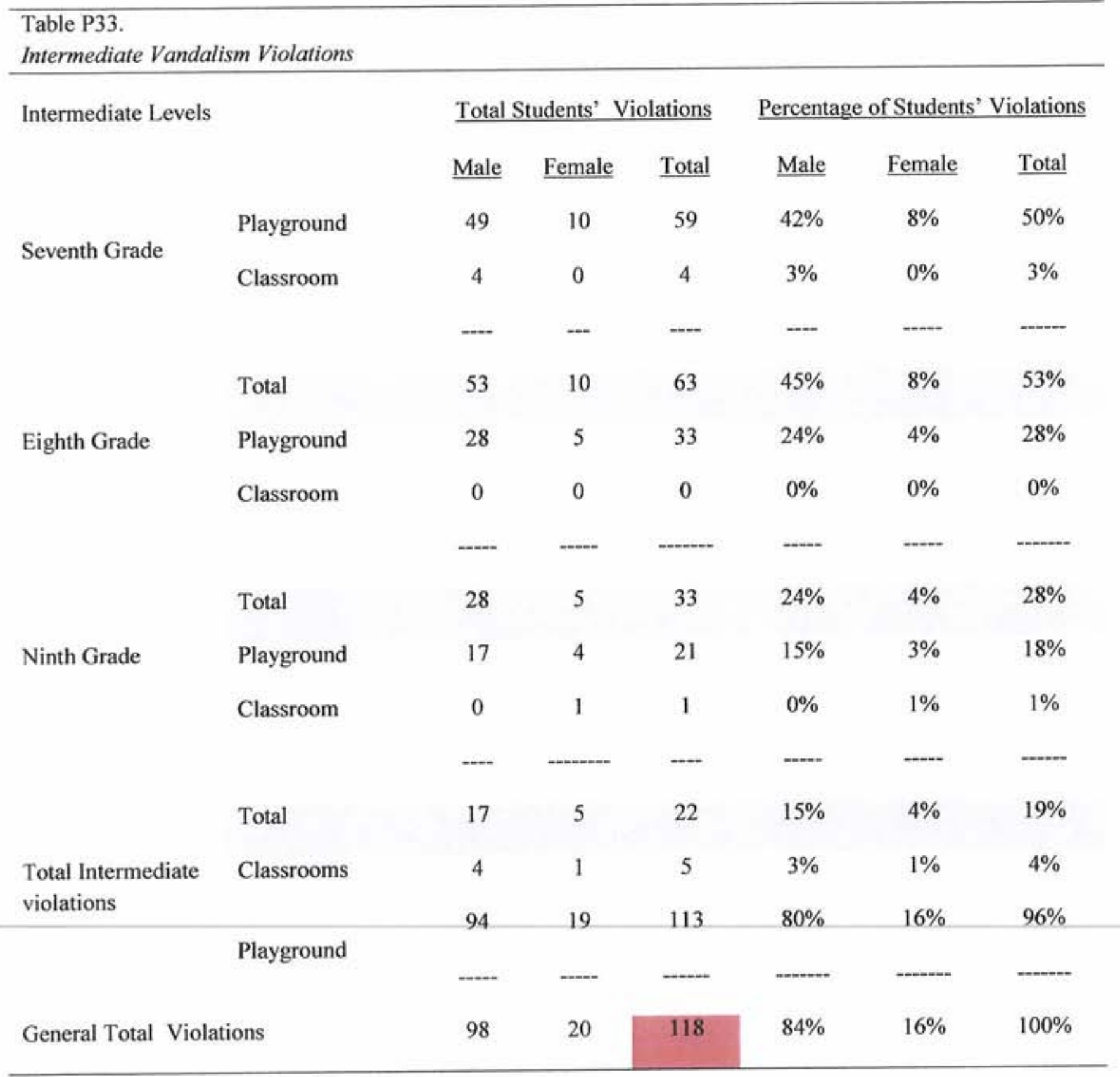




\begin{tabular}{|c|c|c|c|c|c|c|c|c|c|c|c|}
\hline \multicolumn{12}{|c|}{$\begin{array}{l}\text { Table P34. } \\
\text { Evaluation of Vandalism Code Enforcement }\end{array}$} \\
\hline \multirow[t]{2}{*}{ Intermediate Levels } & \multicolumn{3}{|c|}{$\begin{array}{c}\text { Total Students' } \\
\text { Violations }\end{array}$} & \multicolumn{2}{|c|}{$\begin{array}{c}\text { Frequency } \\
\text { of Teachers } \\
\text { Reactions }\end{array}$} & \multicolumn{2}{|c|}{$\begin{array}{c}\text { Frequency of } \\
\text { Supervisor's } \\
\text { Reactions }\end{array}$} & \multicolumn{2}{|c|}{$\begin{array}{c}\text { Frequency of } \\
\text { Referrals }\end{array}$} & \multirow[t]{2}{*}{$\underline{\text { PAR }}$} & \multirow[t]{2}{*}{$\begin{array}{l}\text { Evaluation of } \\
\text { Enforcement }\end{array}$} \\
\hline & 2 & 오 & Total & 2 & 오 & 2 & 오 & 1 & 오 & & \\
\hline Seventh Grade & 53 & 10 & 63 & 3 & 0 & 1 & 0 & 0 & 0 & & \\
\hline Eighth Grade & 28 & 5 & 33 & 0 & 0 & 1 & 0 & 0 & 0 & & \\
\hline \multirow[t]{2}{*}{ Ninth Grade } & 17 & 5 & 22 & 0 & 0 & 0 & 0 & 0 & 0 & & \\
\hline & $\cdots$ & $\ldots$ & $\cdots$ & $\cdots$ & $\cdots$ & -..- & $\cdots$ & $\cdots$ & $\cdots$ & & \\
\hline Total & 98 & 20 & 118 & 3 & 0 & 2 & 0 & 0 & 0 & 0 & 5 \\
\hline$\%$ Seventh Graders & $45 \%$ & $8 \%$ & $53 \%$ & $75 \%$ & $0 \%$ & $1 \%$ & $0 \%$ & $0 \%$ & $0 \%$ & $0 \%$ & 5 \\
\hline \%of Eighth Graders & $24 \%$ & $4 \%$ & $28 \%$ & $0 \%$ & $0 \%$ & $1 \%$ & $0 \%$ & $0 \%$ & $0 \%$ & $0 \%$ & 4 \\
\hline$\%$ of Ninth Graders & $15 \%$ & $4 \%$ & $19 \%$ & $0 \%$ & $0 \%$ & $0 \%$ & $0 \%$ & $0 \%$ & $0 \%$ & $0 \%$ & 5 \\
\hline Percentages & $\ldots$ & $\cdots$ & $\cdots$ & $\cdots$ & $\cdots$ & - & $\cdots$ & $\cdots$ & $\cdots$ & $\cdots$ & $\cdots$ \\
\hline Total Percentages & $84 \%$ & $16 \%$ & 100 & $75 \%$ & $0 \%$ & $2 \%$ & $0 \%$ & $0 \%$ & $0 \%$ & $0 \%$ & 5 \\
\hline
\end{tabular}

Note. $\hat{\delta}=$ Male; $q=$ Female; $P A R=$ Percentages of Administrative Reactions. The percentage of teachers' reactions is calculated by dividing the total teachers' reactions by the total of students' violations in classroom only. The percentage of administrative reactions to teachers' reactions is calculated by dividing the number of referrals by the frequency of teachers' reactions. The data collected from the playground is included. (Evaluation Criteria: 1= Highty Enforced; 2-Quite Enforced; 3 =-Moderately Enforced; $4=$ Slightly Enforced; $5=$ Not Enforced). 
Table P35.

Evaluation of Not Eating in Classroom/Laboratory Code Enforcement

\begin{tabular}{|c|c|c|c|c|c|c|c|c|c|c|}
\hline \multirow[t]{2}{*}{$\begin{array}{l}\text { Intermediate } \\
\text { Levels }\end{array}$} & \multicolumn{3}{|c|}{$\begin{array}{c}\text { Total Students' } \\
\text { Violations }\end{array}$} & \multicolumn{3}{|c|}{$\begin{array}{l}\text { Frequency of Teachers } \\
\text { Reactions }\end{array}$} & $\begin{array}{l}\text { Freq } \\
\text { of Re }\end{array}$ & $\begin{array}{l}\text { ency } \\
\text { irals }\end{array}$ & $\begin{array}{c}\text { Percentage of } \\
\text { Administrative } \\
\underline{\text { Reactions }}\end{array}$ & $\begin{array}{l}\text { Evaluation of } \\
\text { Enforcement }\end{array}$ \\
\hline & 2 & 오 & Total & $\underline{2}$ & 오 & Total & 2 & 오 & & \\
\hline Seventh Grade & 0 & 0 & 0 & 0 & 0 & 0 & 0 & 0 & 0 & 1 \\
\hline Eighth Grade & 0 & 1 & 1 & 0 & 0 & 0 & 0 & 0 & 0 & 5 \\
\hline Ninth Grade & 2 & 3 & 5 & 2 & 3 & 5 & 1 & 0 & 1 & 1 \\
\hline & $-\cdots$ & $-\ldots$ & .... & $\ldots$ & $\cdots$ & 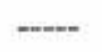 & $\ldots$ & -.... & $\ldots$ & \\
\hline Total & 2 & 4 & 6 & 2 & 3 & 5 & 1 & 0 & 1 & 1 \\
\hline Percentages & & & & & & & & & & \\
\hline Seventh Grade & $0 \%$ & $0 \%$ & $0 \%$ & $0 \%$ & $0 \%$ & $0 \%$ & $0 \%$ & $0 \%$ & $0 \%$ & \\
\hline Eighth Grade & $0 \%$ & $17 \%$ & $17 \%$ & $0 \%$ & $0 \%$ & $0 \%$ & $0 \%$ & $0 \%$ & $0 \%$ & \\
\hline Ninth Grade & $33 \%$ & $50 \%$ & $83 \%$ & $100 \%$ & $100 \%$ & $100 \%$ & $16 \%$ & $0 \%$ & $100 \%$ & \\
\hline & $-\cdots$ & $\cdots$ & -..- & $-\cdots$ & $-\cdots$ & $\cdots$ & $\cdots$ & ---- & - & \\
\hline Total Percentage & $33 \%$ & $67 \%$ & $100 \%$ & $100 \%$ & $100 \%$ & $90 \%$ & $16 \%$ & $0 \%$ & $100 \%$ & 1 \\
\hline
\end{tabular}

Note, $\delta=$ Male; $q=$ Female. The percentage of teachers' reactions is calculated by dividing the total teachers' reactions by the total of students' violations. The percentage of administrative reactions to teachers' reactions is calculated by dividing the number of referrals by the frequency of teachers' reactions. Evaluation Criteria: $1=$ Highly Enforced; 2 = Quite Enforced; 3 = moderately enforced; 4 = Slightly Enforced; $5=$ Not Enforced). 
Table P36.

Evaluation of Chewing Gum Code Enforcement

\begin{tabular}{|c|c|c|c|c|c|c|c|c|c|c|}
\hline \multirow[t]{2}{*}{ Intermediate Levels } & \multicolumn{3}{|c|}{$\begin{array}{c}\text { Total Students' } \\
\text { Violations }\end{array}$} & \multicolumn{3}{|c|}{$\begin{array}{c}\text { Frequency of Teachers } \\
\text { Reactions }\end{array}$} & \multicolumn{2}{|c|}{$\begin{array}{l}\text { Frequency of } \\
\text { Referrals }\end{array}$} & \multirow[t]{2}{*}{$\underline{\text { PAR }}$} & \multirow[t]{2}{*}{$\begin{array}{l}\text { Evaluation of } \\
\text { Enforcement }\end{array}$} \\
\hline & 2 & 오 & Total & s & 오 & Total & a & 오 & & \\
\hline Seventh Grade & 0 & 0 & 0 & 0 & 0 & 0 & 0 & 0 & 0 & \\
\hline Eighth Grade & 1 & 0 & 1 & 0 & 0 & 0 & 0 & 0 & 0 & 5 \\
\hline \multirow[t]{2}{*}{ Ninth Grade } & 0 & 1 & 1 & 0 & 1 & 1 & 0 & 0 & 0 & 1 \\
\hline & -- & $\cdots$ & $\cdots$ & $\cdots$ & $\cdots$ & --- & $-\cdots$ & $\cdots$ & --- & $\ldots$ \\
\hline Total & 1 & 1 & 2 & 0 & 1 & 1 & 0 & 0 & 0 & 1 \\
\hline \multicolumn{11}{|l|}{ Percentages } \\
\hline$\%$ Seventh Grade & $0 \%$ & $0 \%$ & $0 \%$ & $0 \%$ & $0 \%$ & $0 \%$ & $0 \%$ & $0 \%$ & $0 \%$ & \\
\hline \% Eighth Grade & $50 \%$ & $0 \%$ & $50 \%$ & $0 \%$ & $0 \%$ & $0 \%$ & $0 \%$ & $0 \%$ & $0 \%$ & \\
\hline$\%$ Ninth Grade & $0 \%$ & $50 \%$ & $50 \%$ & $0 \%$ & $100 \%$ & $100 \%$ & $0 \%$ & $0 \%$ & $0 \%$ & \\
\hline & $\ldots$ & -..- & 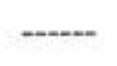 & $\cdots$ & $\cdots$ & $\cdots$ & $\cdots$ & $\cdots$ & ---- & \\
\hline Total Percentage & $50 \%$ & $50 \%$ & $100 \%$ & $0 \%$ & $100 \%$ & $100 \%$ & $0 \%$ & $0 \%$ & $0 \%$ & \\
\hline
\end{tabular}

Note. $\hat{\delta}=$ Male $; q=$ Female; PAR = Percentage of Administrative Reactions. The percentage of teachers' reactions is calculated by dividing the total teachers' reactions by the total of students' violations. The percentage of administrative reactions to teachers' reactions is calculated by dividing the number of referrals by the frequency of teachers' reactions. Evaluation Criteria: $1=$ Highly Enforced; $2=$ Quite Enforced; $3=$ Moderately Enforced; 4 = Slightly Enforced; 5 = Not Enforced). 


\begin{tabular}{|c|c|c|c|c|c|c|c|c|c|c|}
\hline Evaluation of Che & ing Cod & Enfor & ement & & & & & & & \\
\hline \multirow[t]{2}{*}{$\begin{array}{l}\text { Intermediate } \\
\text { Levels }\end{array}$} & \multicolumn{3}{|c|}{$\begin{array}{c}\text { Total Students' } \\
\text { Violations }\end{array}$} & \multicolumn{3}{|c|}{$\begin{array}{c}\text { Frequency of Teachers } \\
\text { Reactions }\end{array}$} & \multicolumn{2}{|c|}{$\begin{array}{l}\text { Frequency } \\
\text { of Referrals }\end{array}$} & \multirow[t]{2}{*}{$\begin{array}{c}\text { Percentage of } \\
\text { Administrative } \\
\text { Reactions }\end{array}$} & \multirow[t]{2}{*}{$\begin{array}{l}\text { Evaluation of } \\
\text { Enforcement }\end{array}$} \\
\hline & 2 & 오 & $\underline{\text { Total }}$ & $\approx$ & 오 & $\underline{\text { Total }}$ & $\hat{s}$ & 오 & & \\
\hline Seventh & 1 & 0 & 1 & 1 & 0 & 1 & 1 & 0 & $100 \%$ & 1 \\
\hline Eighth & 0 & 0 & 0 & 0 & 0 & 0 & 0 & 0 & & \\
\hline \multirow[t]{2}{*}{ Ninth } & 0 & 0 & 0 & 0 & 0 & 0 & 0 & 0 & & \\
\hline & $\cdots$ & $\cdots$ & $\cdots$ & $\cdots$ & $\cdots$ & $\cdots$ & $-\cdots$ & $\cdots$ & & \\
\hline Total & 1 & 0 & 1 & 1 & 0 & 1 & 1 & 0 & & \\
\hline \multicolumn{11}{|l|}{ Percentages } \\
\hline Seventh & $100 \%$ & $0 \%$ & $100 \%$ & $100 \%$ & $0 \%$ & $100 \%$ & $100 \%$ & $0 \%$ & & \\
\hline Eighth & $0 \%$ & $0 \%$ & $0 \%$ & $0 \%$ & $0 \%$ & $0 \%$ & $0 \%$ & $0 \%$ & & \\
\hline \multirow[t]{2}{*}{ Ninth } & $0 \%$ & $0 \%$ & $0 \%$ & $0 \%$ & $0 \%$ & $0 \%$ & $0 \%$ & $0 \%$ & & \\
\hline & $m$ & $\ldots$ & $\cdots$ & 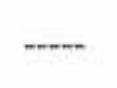 & $\cdots$ & - & $\cdots$ & $\cdots$ & & \\
\hline Total Percentage & $100 \%$ & $0 \%$ & $100 \%$ & $100 \%$ & $0 \%$ & $100 \%$ & $100 \%$ & $0 \%$ & & \\
\hline
\end{tabular}

Note. $\vec{\delta}=$ Male $; \phi=$ Female. The percentage of teachers' reactions is calculated by dividing the total teachers' reactions by the total of students' violations. The percentage of administrative reactions is calculated by dividing the number of referrals by the frequency of teachers' reactions. Evaluation Criteria: 1= Highly Enforced; 2 = Quite Enforced; 3 = Moderately Enforced; 4 = Slightly Enforced; $5=$ Not Enforced). 


\section{Appendix $Q$}

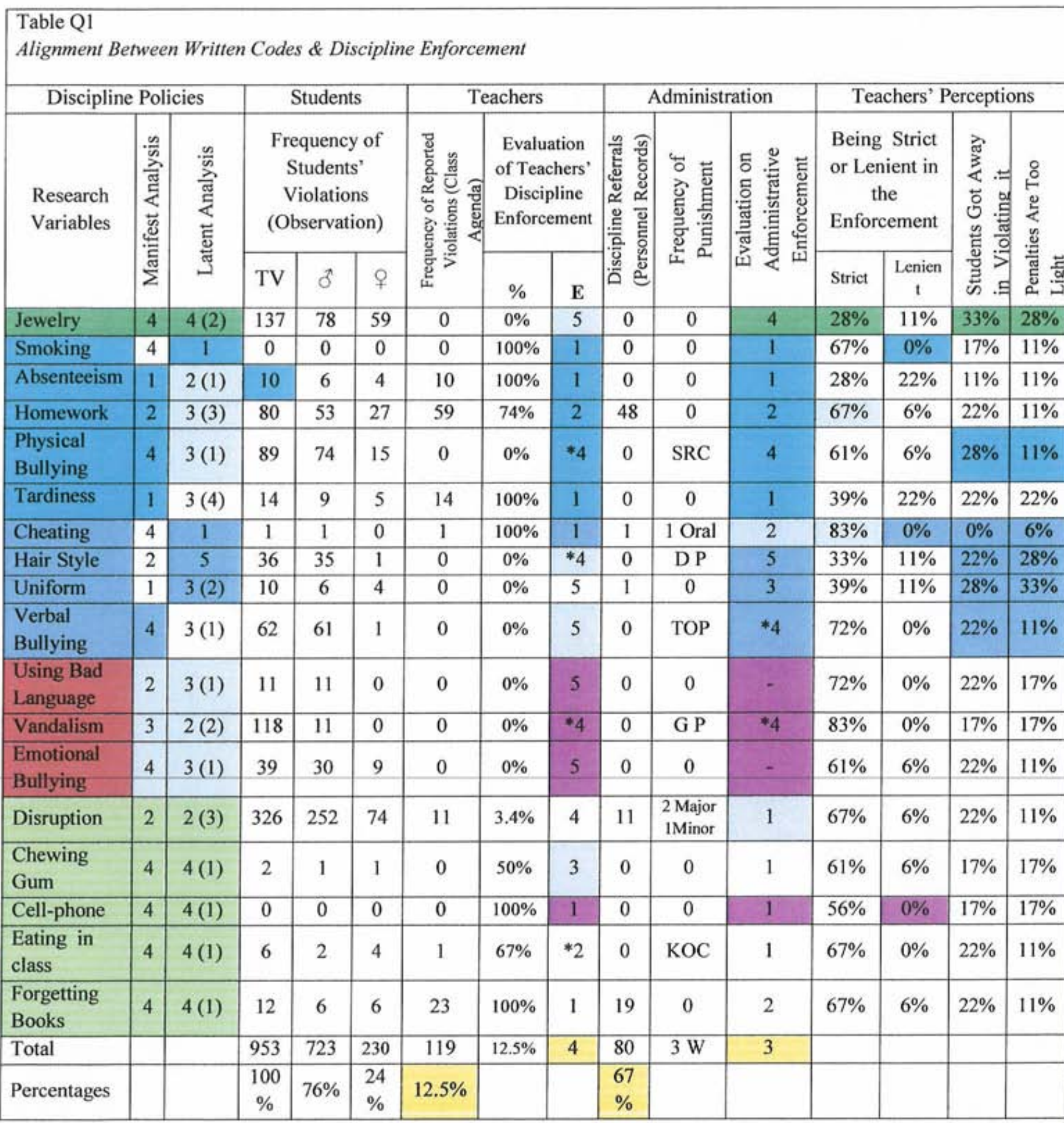


Note. $\mathrm{E}=$ Evaluation; $\mathrm{TV}=$ Total Violation; $\%=$ Percentage; $\mathrm{D} \mathrm{P}=$ Deduction Points; $\mathrm{G} \mathrm{P}=$ General Punishment; TOP = Time Out Punishment; SRC = Staff Reported on Violation in Corridors; KOC = Keeping Students Outside Class; W = Warning; (-) $=$ Presenting the order of the same level; ${ }^{*}=$ Used Punishment Not Stated in Written Codes

Categories for Evaluating Rule Enforcement:

1= Highly; 2 =Somewhat $3=$ Moderately; $4=$ Slightly; $5=$ Not.

Categories for Manifest Analysis in the Repetition of Words:

1 = Highly; 2 = Somewhat 3 = Moderately; $4=$ Slightly; $5=$ Not.

Categories for Latent Analysis in Providing Warning:

1 = Highly; 2 = Somewhat 3 = Moderately; $4=$ Slightly; $5=$ Not.

Green Cells: Reflect an Alignment between Two Kinds of Analysis and One Type of Enforcement

Olive Green Cells: Reflect an Alignment between Two Kinds of Analysis and Discrepancy with Enforcement

Bleu Cells: Reflect an Alignment between One Kind of Analysis and Two Types of Enforcement

Dark Blue Cells: Reflect Alignment between one Kind of Analysis and one Type of Enforcement

Light Blue Cells: Reflect Slight Alignment

Red Cells: Reflect Discrepancy between Written Codes and Different Types of Enforcement

Dark Purple Cells: Reflect Alignment between Teachers and Administrative Enforcement

Yellow Cells: Final Evaluation on the Discipline Enforcement 


\begin{tabular}{|c|c|c|c|c|}
\hline \multicolumn{5}{|c|}{$\begin{array}{l}\text { Table Q2. } \\
\text { Part of Appendix K: Students' Responses }\end{array}$} \\
\hline Q9: & $\begin{array}{l}\text { Fair enforcement of discipline codes by } \\
\text { the teachers }\end{array}$ & $60 \%$ Yes & $39 \%$ No & \\
\hline Q10: & Strict enforcement by the teachers & $72 \%$ Yes & $27 \%$ No & \\
\hline Q11: & $\begin{array}{l}\text { Doing something \& being surprised it is } \\
\text { against discipline rules }\end{array}$ & $44 \%$ Yes & $51 \%$ No & \\
\hline Q12: & $\begin{array}{l}\text { Students get away with violating discipline } \\
\text { rules }\end{array}$ & $\begin{array}{l}20 \% \\
\text { Never }\end{array}$ & $\begin{array}{l}64 \% \\
\text { Sometimes }\end{array}$ & $\begin{array}{l}12.5 \% \text { Most } \\
\text { of the time }\end{array}$ \\
\hline Q13: & Being blamed when it is not student's fault & $36 \%$ Never & $\begin{array}{l}17 \% \\
\text { Occasionally }\end{array}$ & $\begin{array}{l}44 \% \\
\text { Sometimes }\end{array}$ \\
\hline
\end{tabular}


Appendix R

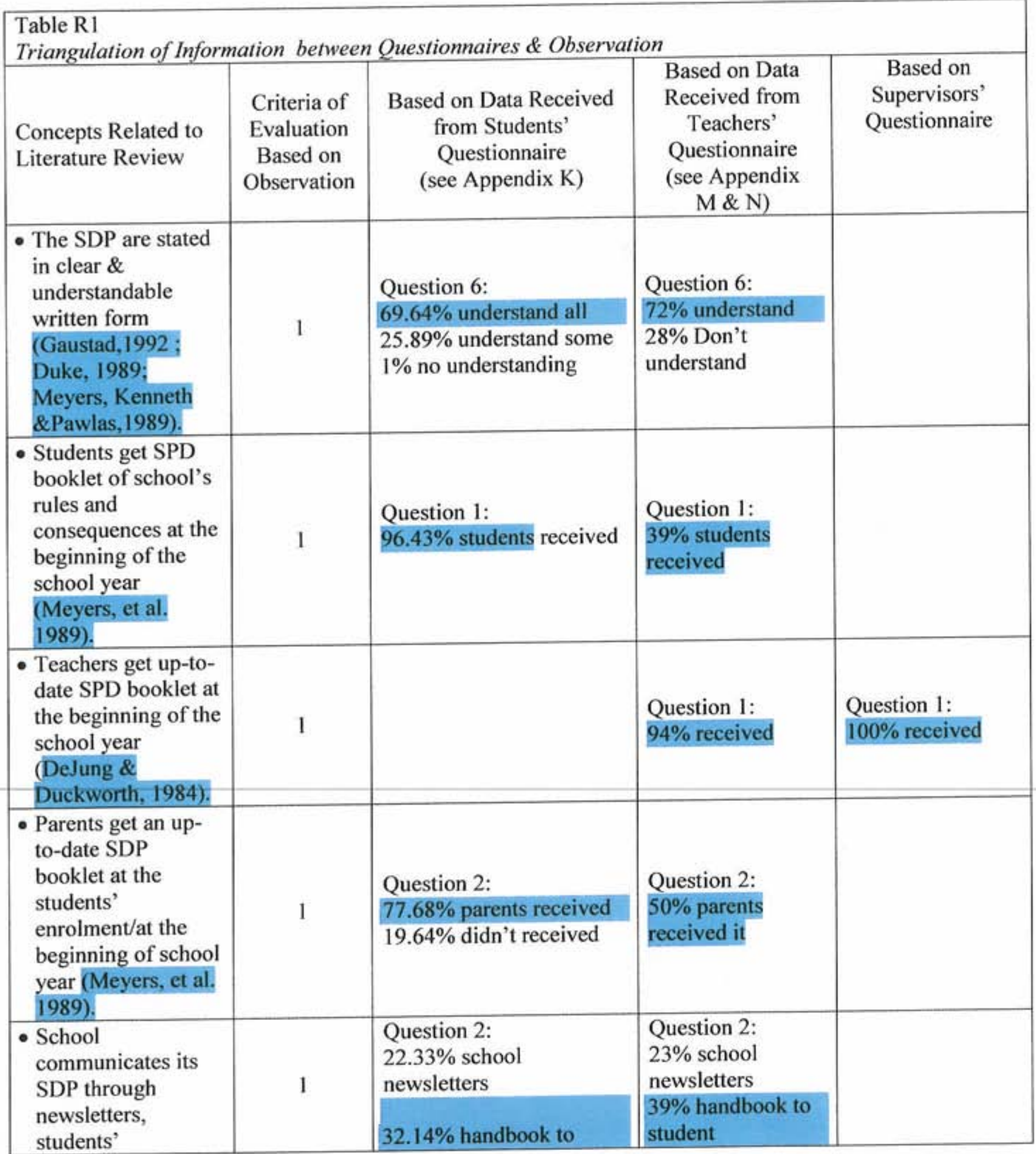




\begin{tabular}{|c|c|c|c|c|}
\hline $\begin{array}{l}\text { assemblies \& } \\
\text { handbooks (Duke } \\
\text { 1989; Meyers, et } \\
\text { al. 1989) }\end{array}$ & & $\begin{array}{l}\text { student } \\
25.89 \% \text { handbooks to } \\
\text { parents }\end{array}$ & $\begin{array}{l}50 \% \text { handbooks to } \\
\text { parents }\end{array}$ & \\
\hline $\begin{array}{l}\text { Students are } \\
\text { involved in the } \\
\text { development of } \\
\text { SDP (Cameron, } \\
\text { 2006) }\end{array}$ & 5 & $\begin{array}{l}\text { Question 8: } \\
52.68 \% \text { involved } \\
42.86 \% \text { not involved }\end{array}$ & $\begin{array}{l}\text { Question } 12 \& \text { \& } \\
9 \text { in Table): } \\
11 \% \text { generally } \\
\text { involved } \\
28 \% \text { sometimes } \\
\text { involved } \\
11 \% \text { seldom } \\
\text { involved } \\
44 \% \text { never } \\
\text { involved }\end{array}$ & $\begin{array}{c}50 \% \text { Never } \\
\text { involved } \\
50 \% \text { Sometimes } \\
\text { involved }\end{array}$ \\
\hline $\begin{array}{l}\text { Teachers are } \\
\text { involved in the } \\
\text { development of } \\
\text { SDP (Cameron, } \\
\text { 2006) }\end{array}$ & 5 & & $\begin{array}{l}\text { Question } 10: \\
11 \% \text { involved } \\
89 \% \text { not involved }\end{array}$ & $\begin{array}{l}\text { Question 10: } \\
50 \% \text { They are } \\
\text { involved in } \\
\text { students' } \\
\text { evaluation, } \\
\text { warning, parents' } \\
\text { meeting, \& dress } \\
\text { code }\end{array}$ \\
\hline $\begin{array}{l}\text { Teachers remind } \\
\text { students of SDP } \\
\text { from time to time } \\
\text { (Meyers, et al. } \\
\text { 1989). }\end{array}$ & \begin{tabular}{l}
\multicolumn{1}{c}{ 1 } \\
(after \\
summer \\
vacations \& \\
when they \\
misbehaved)
\end{tabular} & $\begin{array}{l}\text { Question } 4 \text { : } \\
67.86 \% \text { after summer } \\
\text { vacations } \\
12.5 \% \text { after summer \& } \\
\text { winter vacations } \\
\\
16.96 \% \text { no } \\
\end{array}$ & $\begin{array}{l}\text { Question } 3 \& 4: \\
34 \% \text { after summer } \\
\text { vacations } \\
22 \% \text { after summer } \\
\& \text { winter vacations } \\
39 \% \text { at any urgent } \\
\text { issue } \\
6 \% \text { no } \\
\end{array}$ & \\
\hline $\begin{array}{l}\text { - Students are trained } \\
\text { on school's rules \& } \\
\text { procedures during } \\
\text { first two weeks of } \\
\text { school year (Black } \\
\text { \& Down, 1992). }\end{array}$ & 5 & $\begin{array}{l}\text { Question } 5 \text { : } \\
45.53 \% \text { received training } \\
41.96 \% \text { no training }\end{array}$ & $\begin{array}{l}\text { Question } 5: \\
61 \% \text { received } \\
\quad \text { training } \\
33 \% \text { no training }\end{array}$ & \\
\hline $\begin{array}{l}\text { Students are subject } \\
\text { to consequences in } \\
\text { case of violating } \\
\text { SDP (Adams, } \\
\text { 2000). }\end{array}$ & 1 & $\begin{array}{l}\text { Question 14: } \\
24 \% \text { of students } \\
\text { receiving Oral warning } \\
\text { Question 15: }\end{array}$ & $\begin{array}{l}\text { Teachers were } \\
\text { involved in } \\
\text { providing: } \\
\text { Question } 25 \text { : } \\
56 \% \text { of Teachers } \\
\text { were involved in } \\
\text { providing students } \\
\text { with Oral warning } \\
\text { Question 26: }\end{array}$ & \\
\hline
\end{tabular}




\begin{tabular}{|c|c|c|c|c|}
\hline & & $\begin{array}{l}10 \% \text { of students received } \\
\text { Minor written warning } \\
\text { Question } 16 \text { : } \\
5.4 \% \text { of students received } \\
\text { Major written warning } \\
\text { (Data of the previous } \\
\text { academic year) }\end{array}$ & $\begin{array}{l}28 \% \text { of teachers } \\
\text { were involved in } \\
\text { providing students } \\
\text { with Minor written } \\
\text { warning } \\
\text { Question } 27 \text { : } \\
17 \% \text { of teachers } \\
\text { were involved in } \\
\text { providing students } \\
\text { with Major written } \\
\text { warning } \\
\text { (Data of the } \\
\text { previous academic } \\
\text { year) }\end{array}$ & \\
\hline $\begin{array}{l}\text { Duties of } \\
\text { controlling } \\
\text { students' behavior } \\
\text { are divided between } \\
\text { teachers \& staff } \\
\text { (DeJung \& } \\
\text { Duckworth, 1984). }\end{array}$ & 3 & & $\begin{array}{l}\text { Question } 2 \text { in } \\
\text { Table: } \\
\text { (see Appendix } \mathrm{O} \text { ) }\end{array}$ & \\
\hline $\begin{array}{l}\text { - Teachers were } \\
\text { lenient in the } \\
\text { enforcement which } \\
\text { weakened } \\
\text { consistent } \\
\text { enforcement } \\
\text { (Cameron, 2006) }\end{array}$ & 4 & $\begin{array}{l}\text { Question } 10 \text { : } \\
27 \% \text { believed that } \\
\text { teachers were lenient in } \\
\text { Discipline enforcement }\end{array}$ & $\begin{array}{l}\text { Question } 10 \text { in } \\
\text { Table: } \\
\text { (see Appendix O) }\end{array}$ & \\
\hline $\begin{array}{l}\text { Teachers were strict } \\
\text { in the enforcement } \\
\text { which strengthened }\end{array}$ & & $\begin{array}{l}\text { Question 10: } \\
72 \% \text { believed that }\end{array}$ & Question 10 in & \\
\hline $\begin{array}{l}\text { consistent } \\
\text { enforcement } \\
\text { (Gaustad, 1992; } \\
\text { Goodman, 2006). }\end{array}$ & 4 & $\begin{array}{l}\text { teachers were strict in } \\
\text { Discipline enforcement }\end{array}$ & $\begin{array}{c}\text { Table: } \\
\text { (see Appendix O) }\end{array}$ & \\
\hline $\begin{array}{l}\text { - Students get away } \\
\text { with breaking rules } \\
\text { which reflected fair } \\
\text { enforcement } \\
\text { (DeJung \& } \\
\text { Duckworth, 1984). }\end{array}$ & 4 & $\begin{array}{l}\text { Question } 12 \text { : } \\
12.5 \% \text { Get away most of } \\
\text { the time } \\
64 \% \text { Sometimes get away }\end{array}$ & $\begin{array}{l}\text { Question } 5 \text { in } \\
\text { Table: } \\
\text { (see Appendix O) }\end{array}$ & \\
\hline $\begin{array}{l}\text { - Students do } \\
\text { something \& are } \\
\text { surprised it is } \\
\text { against school's }\end{array}$ & 3 & $\begin{array}{l}\text { Question } 11 \\
44 \% \text { replied yes }\end{array}$ & $\begin{array}{l}\text { Question 16: } \\
\text { \& Q7 in Table }\end{array}$ & \\
\hline
\end{tabular}




\begin{tabular}{|c|c|c|c|c|}
\hline $\begin{array}{l}\text { rule (DeJung \& } \\
\text { Duckworth, 1984). }\end{array}$ & & & & \\
\hline $\begin{array}{l}\text { - Students are } \\
\text { blamed when it is } \\
\text { not students' fault } \\
\text { (DeJung \& } \\
\text { Duckworth, 1984). }\end{array}$ & 4 & Question 13: & $\begin{array}{c}\text { Question } 3 \text { in } \\
\text { Table }\end{array}$ & \\
\hline $\begin{array}{l}\text { Students are } \\
\text { making their own } \\
\text { decisions about } \\
\text { obeying rules in } \\
\text { meeting personnel's } \\
\text { expectation } \\
\text { (DeJung \& } \\
\text { Duckworth, 1984). }\end{array}$ & 4 & & Question 13: & Question 13: \\
\hline $\begin{array}{l}\text { - Checking if school } \\
\text { has too many rules } \\
\text { (Duke, 1989). }\end{array}$ & 2 & $\begin{array}{l}\text { Question 7: } \\
\text { A) } 76 \% \text { Yes }\end{array}$ & $\begin{array}{l}\text { Question 9: } \\
\text { A) Yes } 11 \% \\
\text { B) No } 83 \%\end{array}$ & \\
\hline $\begin{array}{l}\text { Students received } \\
\text { oral warning } \\
\text { (Adams,2000; } \\
\text { Gottfredson \& } \\
\text { others, 1989) }\end{array}$ & 1 & Question 14: & Question 25: & \\
\hline $\begin{array}{l}\text { - Students received } \\
\text { minor written } \\
\text { warning } \\
\text { (Adams,2000) }\end{array}$ & 1 & Question 15: & Question 26: & \\
\hline $\begin{array}{l}\text { - Students received } \\
\text { major written } \\
\text { warning } \\
\text { (Adams,2000) } \\
\end{array}$ & 1 & Question 16: & Question 27: & \\
\hline $\begin{array}{l}\text { - School is a safe } \\
\text { place from bullies } \\
\text { (Cameron, 2006) }\end{array}$ & 3 & Question 17: & Question $28 \& 30$ & \\
\hline $\begin{array}{l}\text { - Students contact } \\
\text { after being bullied } \\
\text { (Cameron, 2006) }\end{array}$ & 4 & Question 18: & Question 29: & \\
\hline $\begin{array}{l}\text { - Steps needed to } \\
\text { control students' } \\
\text { bullying (Cameron, } \\
2006 \text { ) }\end{array}$ & 4 & Question 19: & Question 31 \& 32 & \\
\hline $\begin{array}{l}\text { School discipline } \\
\text { rule that needed to } \\
\text { be changed }\end{array}$ & 3 & Question 20: & Question $(1,3$, & \\
\hline
\end{tabular}




\begin{tabular}{|l|l|l|l|l|}
\hline (Cameron, 2006) & & $4,6,8$ in Table) & \\
\hline $\begin{array}{l}\text { - The discipline rule } \\
\text { that is missing } \\
\text { (Cameron, 2006) }\end{array}$ & 4 & Question 21: & Question 33: & \\
\hline $\begin{array}{l}\text { Note. SPD = School Discipline Policies. Criteria of evaluation during observation: } 1=\text { Highly achieved; } 2= \\
\text { Somewhat achieved; 3 = Moderately achieved; } 4=\text { Slightly achieved; } 5=\text { Not achieved. Blue cells = } \\
\text { Alignment between instruments \& literature Review. Blue cells reflect triangulation of information. }\end{array}$ \\
\hline
\end{tabular}




\section{Appendix S}

Table S1.

Supervisors' Responses on Questionnaire

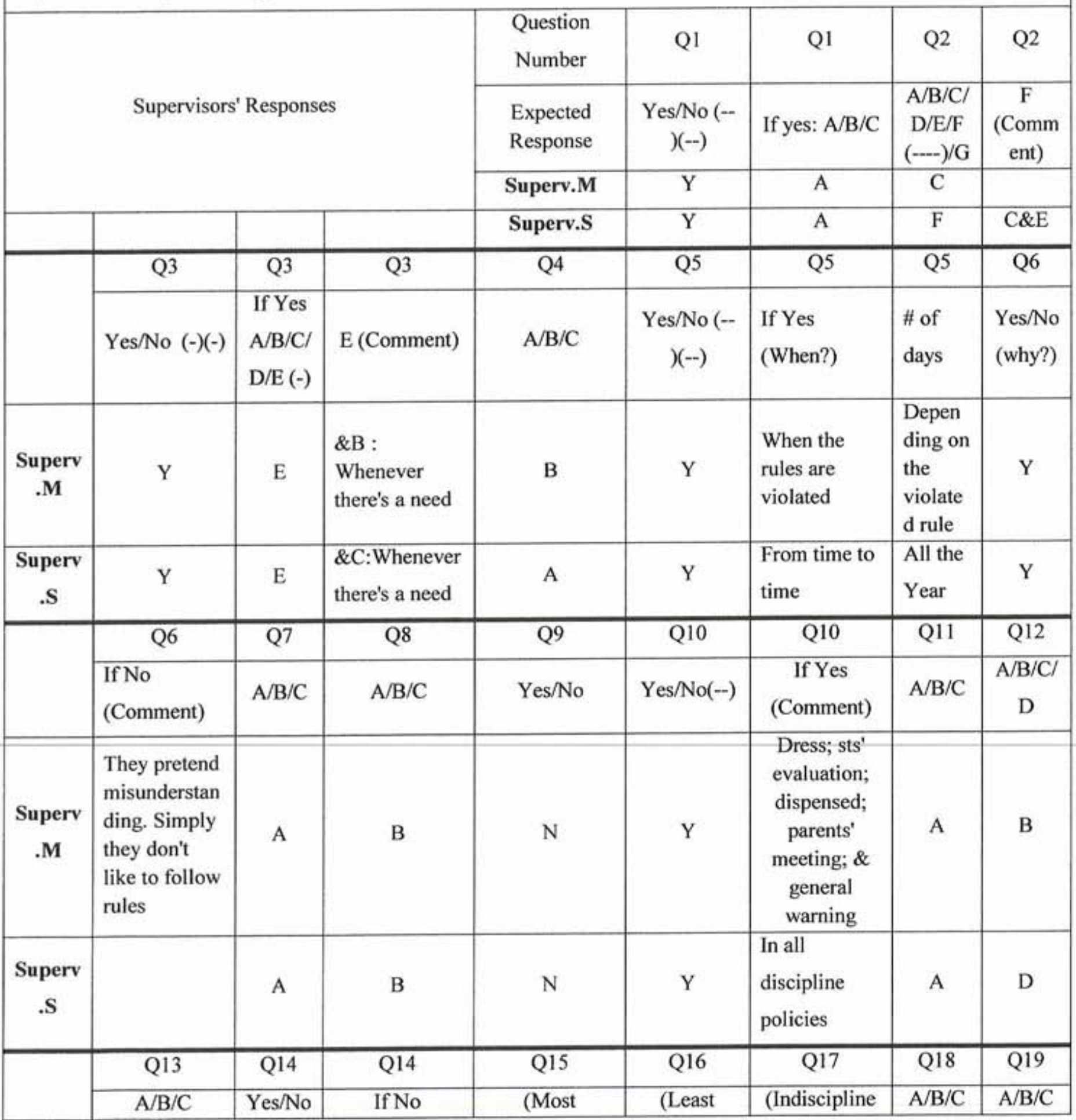




\begin{tabular}{|c|c|c|c|c|c|c|c|c|}
\hline & & (why?) & (Comment) & $\begin{array}{c}\text { effectively } \\
\text { Implemented) }\end{array}$ & $\begin{array}{l}\text { effectively } \\
\text { Implement } \\
\text { ed) }\end{array}$ & $\begin{array}{c}\text { Causing } \\
\text { Most Stress) }\end{array}$ & & \\
\hline $\begin{array}{l}\text { Superv } \\
\text {.M }\end{array}$ & A & Y & & $\begin{array}{l}\text { Attendence, } \\
\text { absenteeism, } \\
\text { tests, } \\
\text { assessment, } \\
\text { meetings, trips }\end{array}$ & $\begin{array}{l}\text { School } \\
\text { uniform, } \\
\text { appearance, } \\
\text { cheating(not } \\
\text { all Ts. } \\
\text { Inform } \\
\text { admin. On } \\
\text { cheating }\end{array}$ & $\begin{array}{l}\text { Cheating, \& } \\
\text { smoking }\end{array}$ & B & A \\
\hline $\begin{array}{c}\text { Superv } \\
\text {.S }\end{array}$ & A & Y & $\begin{array}{l}\text { Results are } \\
\text { satisfactory }\end{array}$ & Order in class & $\begin{array}{l}\text { Discipline } \\
\text { in corridors }\end{array}$ & $\begin{array}{l}\text { Uniform } \\
\text { violation }\end{array}$ & B & A \\
\hline & Q20 & Q21 & Q22 & Q23 & Q24 & Q25 & Q25 & Q25 \\
\hline $\begin{array}{l}\text { Superv } \\
\text {.M }\end{array}$ & $\mathrm{A} / \mathrm{B} / \mathrm{C}$ & $\mathrm{A} / \mathrm{B} / \mathrm{C}$ & $\mathrm{A} / \mathrm{B} / \mathrm{C}$ & $\mathrm{A} / \mathrm{B} / \mathrm{C}$ & $\mathrm{A} / \mathrm{B} / \mathrm{C} / \mathrm{D}$ & Yes/No & $\begin{array}{l}\text { \# of } \\
\text { times }\end{array}$ & $\begin{array}{l}\text { Main } \\
\text { reason }\end{array}$ \\
\hline $\begin{array}{c}\text { Superv } \\
\text {.S }\end{array}$ & & & $\mathrm{C}$ & A & D & Y & $\begin{array}{l}12 \\
\text { times }\end{array}$ & 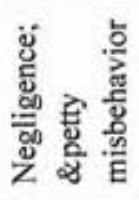 \\
\hline & B & B & $\mathrm{C}$ & A & A & $\mathrm{N}$ & & \\
\hline & Q26 & Q26 & Q26 & Q27 & Q27 & Q27 & Q28 & Q29 \\
\hline & Yes/No & $\begin{array}{l}\text { \# of } \\
\text { time }\end{array}$ & Main reason & Yes/No & \# of times & Main reason & Yes/No & Yes/No \\
\hline Superv & & & & & & Misbehaving & & \\
\hline $\mathrm{M}$ & $\mathrm{Y}$ & 1 time & No comment & $\mathrm{Y}$ & 2 times & $\begin{array}{l}\text { (laughing,\& } \\
\text { talking) }\end{array}$ & $\mathrm{Y}$ & Y \\
\hline $\begin{array}{c}\text { Superv } \\
\text {.S }\end{array}$ & Y & 1 time & $\begin{array}{l}\text { Misbehavior; } \\
\text { \& laughing }\end{array}$ & Y & 2 times & $\begin{array}{l}\text { Misbehaving } \\
\text { in class } \\
\text { (laughing,\& } \\
\text { talking) }\end{array}$ & $\mathrm{N}$ & $\mathrm{N}$ \\
\hline & \multicolumn{4}{|c|}{ Q29 } & Q30 & Q30 & Q31 & Q31 \\
\hline & \multicolumn{4}{|c|}{ If Yes (How do you treat the bullied \& bully?) } & Yes/No(-) & $\begin{array}{c}\text { How do you } \\
\text { know? }\end{array}$ & $\begin{array}{l}\mathrm{A} / \mathrm{B} / \mathrm{C} / \\
\mathrm{D} / \mathrm{E}(-)\end{array}$ & $\begin{array}{l}\mathrm{E} \\
\text { (Comm }\end{array}$ \\
\hline
\end{tabular}




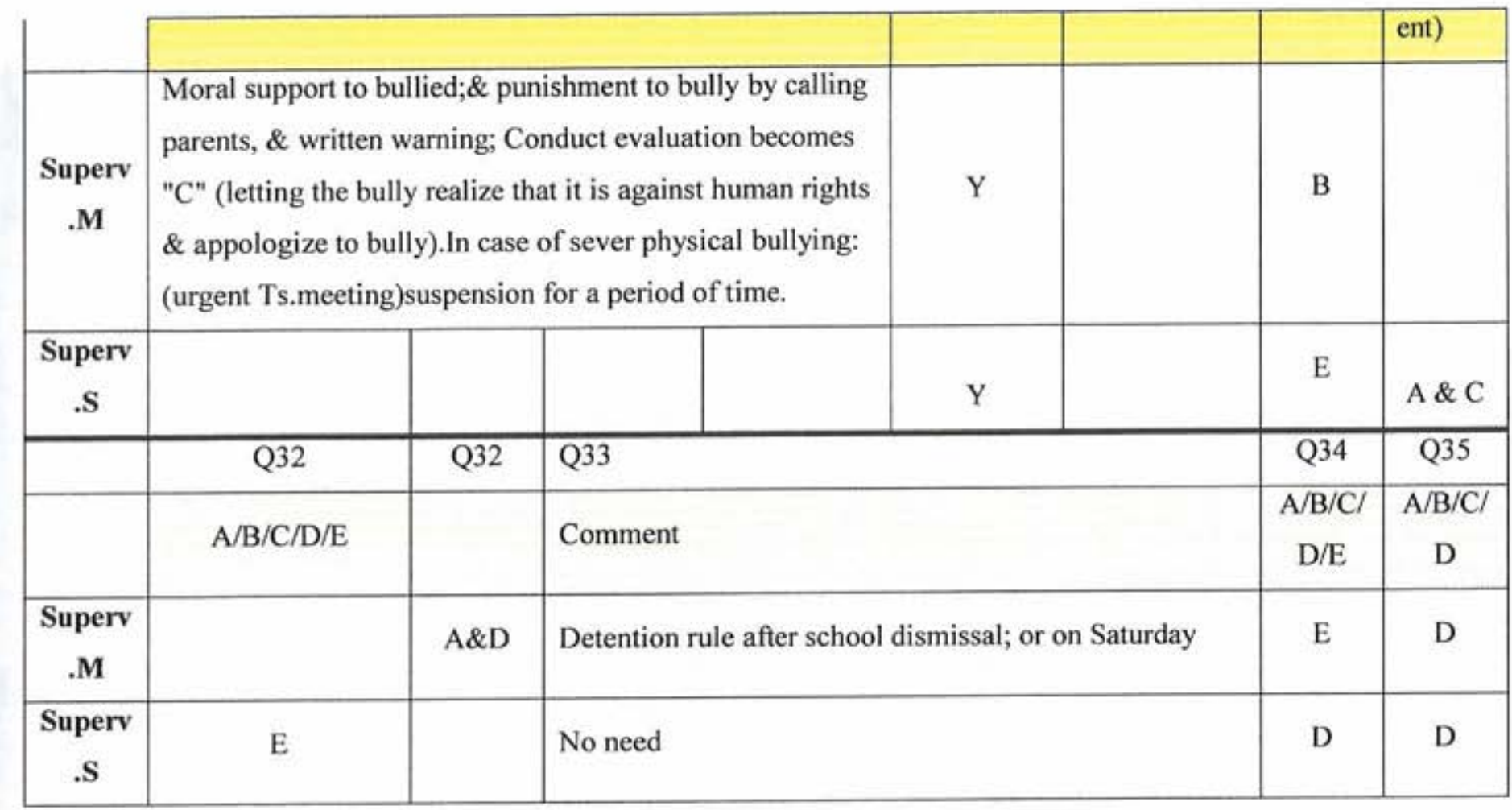

